Jayme Karlos Reis Lopes

\title{
A POLÍTICA DA ELETRICIDADE: modernização estatal brasileira e o setor de energia elétrica do Espírito Santo.
}

\section{Tese de Doutorado}

Tese apresentada como requisito parcial para obtenção de grau de doutor pelo Programa de Pós-Graduação em Ciências Sociais da Pontifícia Universidade Católica do Rio de Janeiro.

Orientador: Prof. Eduardo de Vasconcelos Raposo

Rio de Janeiro

Maio de 2021 


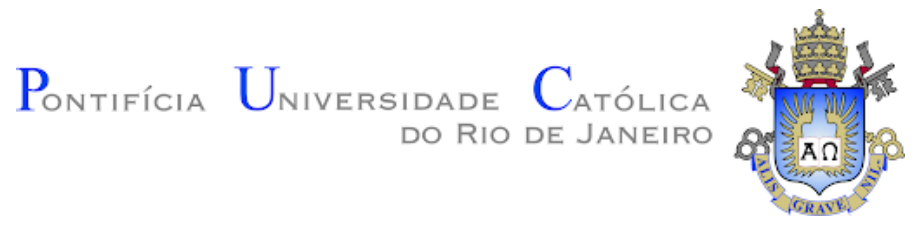

Jayme Karlos Reis Lopes

\begin{abstract}
A POLÍTICA DA ELETRICIDADE: modernização estatal brasileira e o setor de energia elétrica do Espírito Santo.
\end{abstract}

Tese de Doutorado apresentada ao Programa de Pósgraduação em Ciências Sociais da PUC-Rio como requisito parcial para obtenção do grau de Doutor em Ciências Sociais.

Orientador: Prof. Eduardo de Vasconcelos Raposo 
Jayme Karlos Reis Lopes

\begin{abstract}
A POLÍTICA DA ELETRICIDADE: modernização estatal brasileira e o setor de energia elétrica do Espírito Santo.
\end{abstract}

Tese de Doutorado apresentada ao Programa de Pósgraduação em Ciências Sociais da PUC-Rio como requisito parcial para obtenção do grau de Doutor em Ciências Sociais. Aprovada pela Comissão Examinadora abaixo assinada.

Prof. Eduardo de Vasconcelos Raposo - PUC-Rio

Orientador

Departamento de Ciências Sociais - PUC-Rio

Prof. Fernando Cardoso Lima Neto

Departamento de Ciências Sociais - PUC-Rio

Prof. Ricardo Ismael

Departamento de Ciências Sociais - PUC-Rio

Prof. Alexandre Macchione Saes

USP

Prof. Alessandro André Leme

UFF

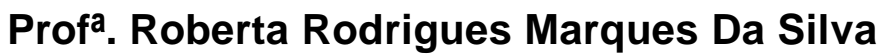

UFF

Rio de Janeiro, 28 de maio de 2021 
Todos os direitos reservados. É proibida a reprodução total ou parcial do trabalho sem autorização da universidade, da autora e do orientador.

\section{Jayme Karlos Reis Lopes}

Graduou-se em Ciências Sociais pela Universidade Federal do Espírito Santo (UFES). Mestre em Antropologia Social pela Faculdade Latino-Americana de Ciências Sociais (FLACSO). É membro do Núcleo de Estudos sobre Federalismo, Política e Desenvolvimento (NUFEPD/PUCRio), do grupo de pesquisa em Elites Políticas Brasileiras (EPB/PUC-Rio) e pesquisador do Centro de Política Comparada (CPC/UFES). É também membro do conselho editorial da Revista Dignidade Re-Vista (PUC-Rio). Tem experiência em pesquisas sobre modernização, infraestrutura e energia. $\mathrm{Em}$ energia sobretudo eletricidade, trabalhando com temas como: transições energéticas, política da energia e política energética, impactos de plantas de produção e transmissão sobre meios socioambientais e as relações entre Estado e infraestrutura energética.

Ficha cartográfica

Lopes, Jayme Karlos Reis

A política da eletricidade: modernização estatal brasileira e o setor de energia elétrica do Espírito Santo / Jayme Karlos Reis Lopes; orientador: Eduardo de Vasconcelos Raposo. - 2021.

$190 \mathrm{f} . ; 30 \mathrm{~cm}$

Tese (doutorado)-Pontifícia Universidade Católica do Rio de Janeiro, Departamento de Ciências Sociais, 2021.

Inclui bibliografia

1. Ciências Sociais - Teses. 2. Energia elétrica. 3. Geração de energia. 4. Modernização estatal. 5. Elites políticas. 6. Estado do Espírito Santo. I. Raposo, Eduardo de Vasconcelos. II. Pontifícia Universidade Católica do Rio de Janeiro. Departamento de Ciências Sociais. III. Título. 
Dedico este trabalho à minha mãe Vera e minha tia Marcia. Sem elas eu não conseguiria, gratidão! 


\section{Agradecimentos}

Agradeço ao meu orientador Professor Eduardo Raposo, pelo estímulo, apoio e compreensão. À PUC-Rio, pela estrutura e oportunidades. Ao Prof. Ricardo Ismael pela ajuda no percurso de elaboração da pesquisa, e pelo convite em participar do Núcleo de Estudo sobre Federalismo, Política e Desenvolvimento (NUFPED/PUCRio). Aos professores que participaram da banca examinadora. A Alexandra Elbakyan e ao Sci-hub pela democratização do conhecimento. A todos os professores e funcionários do Departamento de Ciências Sociais pelos ensinamentos e pela ajuda. Um agradecimento especial às professoras orientadoras e amigas, que fizeram parte desta jornada até o doutorado: Prof ${ }^{a}$ Dra. Aline Trigueiro (UFES) que além de ser minha orientadora de monografia na graduação, também me ajudou enormemente na produção do projeto de doutorado, Prof $^{a}$ Dra. Celeste Ciccarone (UFES) pelo incentivo e a orientação durante toda a graduação e pela ajuda com uma das carta de recomendação para o doutorado e Prof ${ }^{a}$ Dra. Nathalie Puex (FLACSO/Argentina) por ter me orientado durante o mestrado, além de também ter me ajudando com a outra carta de recomendação durante o processo seletivo do doutoramento. Agradeço também a minha tia-avó Maria Aparecida Mattos Alvim, pelo apoio, carinho e acolhimento no Rio de Janeiro, a Ananda Viana pela revisão desta tese, ao apoio de algumas pessoas, amigos que ganhei nestes tempos de doutoramento: Gustavo Cravo, Mario Jorge de Paiva, Elaine Maria, Luiz Fernando Vasconcelos e Vitor Tinoco. 


\section{RESUMO}

Lopes, Jayme Karlos Reis; Raposo, Eduardo de Vasconcelos. A política da eletricidade: modernização estatal brasileira e o setor de energia elétrica do Espírito Santo. Rio de Janeiro, 2021. 190p. Tese de Doutorado Departamento de Ciências Sociais, Pontifícia Universidade Católica do Rio de Janeiro.

Este estudo pretende analisar os processos políticos que se relacionaram a eletrificação do Espírito Santo, investigando sua influência na implementação e configuração do setor de energia elétrica deste estado. Para realizarmos tal tarefa, analisaremos documentos históricos e dados estatísticos a fim de explorar os fenômenos que se relacionam ao processo de industrialização nacional com forte presença estatal durante o século XX, onde o contexto de desigualdades entre as economias dos entes federados foram questões determinantes para a aplicação de distintas políticas para o setor de energia elétrica. Tal conjuntura fez parte dos projetos políticos locais, que dependeram das relações cultivadas entre as diferentes elites políticas regionais e nacionais para sua execução. Neste cenário, no estado do Espírito Santo, as várias etapas do processo de consolidação do sistema elétrico nacional ajudaram a deflagrar a ruptura com o sistema econômico baseado na cafeicultura, determinando uma relação indissociável entre a demanda por eletricidade e a industrialização de base eletrointensiva. Assim, três fatores se mostraram determinantes na configuração do setor de energia elétrica capixaba: (1) a dependência aos interesses históricos do projeto de desenvolvimento nacional; (2) a necessidade da autoprodução de eletricidade por parte do parque industrial em complementação à rede nacional, e aliado a esse fator; (3) a predominância de plantas geradoras termoelétricas. Destaca-se, deste modo, um paradoxo atual: se por um lado a economia espírito-santense se encontra cada vez mais inserida em uma lógica internacional, que pressupõe produção de energia de baixo carbono, descentralizada, através fontes renováveis, por outro lado, tem farta disponibilidade de fontes de energia com alta emissão de $\mathrm{CO}_{2}$ e necessidade imediata de produção interna de energia em larga escala.

Palavras-chave: Energia elétrica. Geração de energia. Modernização estatal. Elites políticas. Estado do Espírito Santo. 


\section{ABSTRACT}

Lopes, Jayme Karlos Reis; Raposo, Eduardo de Vasconcelos. The Politics of Electricity: Brazilian state modernization and Espírito Santo's electricity sector. Rio de Janeiro, 2021. 190p. Doctoral Thesis - Department of Social Sciences, Pontifical Catholic University of Rio de Janeiro.

This study intends to analyze the political processes related to the electrification of Espírito Santo, investigating its influence on the implementation and configuration of the electric power sector in this state. To accomplish this task, we will analyze historical documents and statistical data to explore the phenomena that are related to the national industrialization process with a strong state presence during the 20th century, where the context of inequalities between the economies of the federated entities were decisive issues for the application of different policies for the electric energy sector. This conjuncture was part of the local political projects, which depended on the relations cultivated between the different regional and national political elites for its execution. In this scenario, in the state of Espírito Santo, the various stages of the consolidation process of the national electrical system helped to trigger the rupture with the economic system based on coffee growing, determining an inseparable relationship between the demand for electricity and electro-intensive industrialization. Thus, three factors proved to be decisive in the configuration of the electricity sector in Espírito Santo: (1) the dependence on historical interests of the national development project; (2) the need for selfproduction of electricity by the industrial park in addition to the national grid and coupled with this factor; (3) the predominance of thermoelectric generating plants. In this way, a current paradox stands out: if, on the one hand, the Espírito Santo economy is increasingly inserted in an international logic, which presupposes the production of low-carbon energy, decentralized, through renewable sources, on the other hand, has abundant availability of energy sources with high $\mathrm{CO} 2$ emissions and an immediate need for large-scale domestic energy production.

Keywords: Electricity. Power generation. State modernization. Political elites. State of Espírito Santo. 


\section{SUMÁRIO}

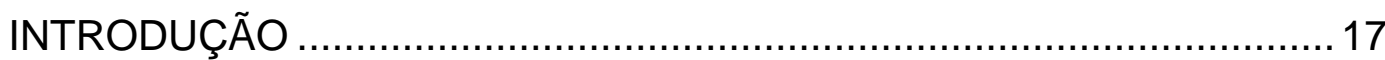

METODOLOGIA

CAPÍTULO 1 - AS ESPECIFICIDADES DO ESTUDO DA RELAÇÃO

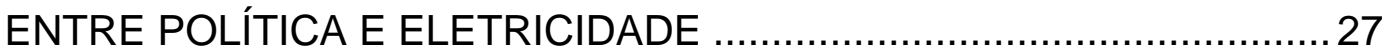

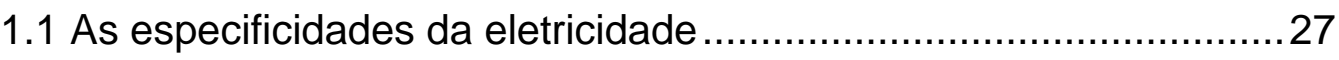

1.1.1 "Energopolitica" e a indissociação entre política e energia .......29

1.2 O Estado como lugar do desenvolvimento energético .....................30

CAPÍTULO 2 - ELETRICIDADE COMO PROJETO DE UM ESTADO

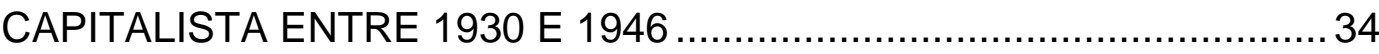

2.1 Espírito Santo: um espelho historicamente isolado do Brasil ..........34

2.1.1 Primeiros momentos da energia elétrica no Espírito Santo.......37

2.2 A década de 1930: quando a mão pesada da modernização nacional bate à porta.

2.3 O projeto modernização nacional e o seu vínculo com setor elétrico.

2.4 Eletricidade e o impacto da modernização no contexto capixaba no pós-1930.

2.4.1 As capacidades estatais

2.4.2 A importância das elites modernizantes e estratégicas no contexto do desenvolvimento brasileiro.

CAPÍTULO 3 - A CARACTERIZAÇÃO DE UM "ESTADO-ELÉTRICO"

ENTRE 1946 E 1964

3.1 O entrelaçamento entre a administração estatal e a infraestrutura de energia elétrica no estado do Espírito Santo. 60

3.2 A empresa pública de energia e o Estado como desenvolvimento

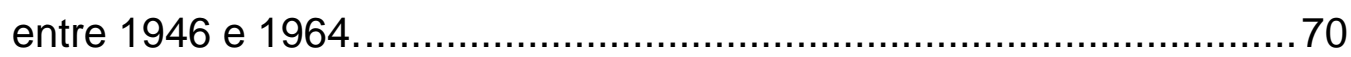

3.2.1 Federalismo moderno e o Brasil .......................................... 75

3.2.2 Um federalismo brasileiro entre a Primeira República e 1964. 76

3.2.3 Entre regionalismo e uma cooperação insulada ..................... 78 
3.2.4 As empresas estaduais do setor elétrico como recorte do debate

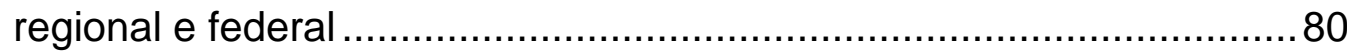

3.2.5 Companhia Estadual de Energia Elétrica (CEEE) do Rio Grande do Sul e a um modelo de desenvolvimento com impacto político nacional.

3.2.6 Companhia Paranaense de Energia (COPEL): entre influência política paulista e o efeito urbano da agroindústria

3.2.7 A Companhia Energética de Minas Gerais (CEMIG) e um projeto nacional de desenvolvimento 91

3.2.8 A influência mineira no plano nacional 96

3.2.9 O setor elétrico como recorte de um protagonismo político regional no desenvolvimento econômico nacional

3.3 Estruturas políticas históricas e a "ameaça" da industrialização capixaba 100

3.3.1 O aprofundamento da crise do café e o "consenso" pela industrialização 103

3.3.2 O sistema elétrico capixaba como parte do mecanismo políticoindustrializante 106

CAPÍTULO 4 - A LÓGICA CENTRALIZADORA ENTRE 1964 E 1989.. 110

4.1 O leviatã verde-oliva: os fundamentos da administração estatal do regime militar na construção de um sistema elétrico nacional. 110

4.2 Uma modernização a partir do nacional e os interesses no desenvolvimento do setor elétrico capixaba.

4.2.1 Os governos da década Élcio Alvares (1975 a 1979), Eurico Resende (1979 a 1983) e a acentuação de um modelo desenvolvimento estatal eletrointensivo-dependente.

4.3 A década de 1980: a política de um setor elétrico em um outro contexto federalista.

4.3.1 O colapso do setor elétrico 132

4.3.1 Um modelo de desenvolvimento em crise e que persiste: os governos Gerson Camata (1983 a 1986) e Max Mauro (1987 a 1991) 
CAPÍTULO 5 - DESCENTRALIZAÇÃO, DESESTATIZAÇÃO E REGULAMENTAÇÃO SOB OS AUSPÍCIOS DO ESTADO NACIONAL NA

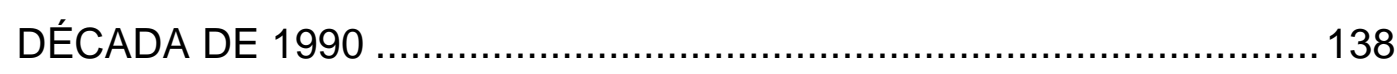

5.1 A privatização da Espírito Santo Centrais Elétricas S/A e o governo Albuíno Azeredo (1991 a 1995) ...................................................... 138

5.1.1 Desestatização e descentralização dos setores elétricos dos

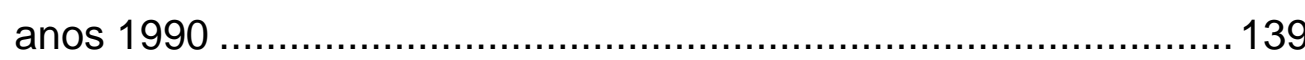

5.1.2 O papel das agências reguladoras........................................ 145

5.1.3 A importância da privatização da ESCELSA em um novo paradigma energético capixaba. .................................................... 148 CAPÍTULO 6 - DA CRISE AO PARADOXO ATUAL: ENTRE UM PROJETO DE DESENVOLVIMENTO ECONÔMICO E A GERAÇÃO DE ENERGIA ELETRICA RENOVAVEL................................................... 151

6.1 O período pós-1990 e o continuidade na alternância entre Paulo Hartung e Renato Casagrande ........................................................151

6.2 Do papel da crise elétrica de 2001 ao desenvolvimento do Mercado

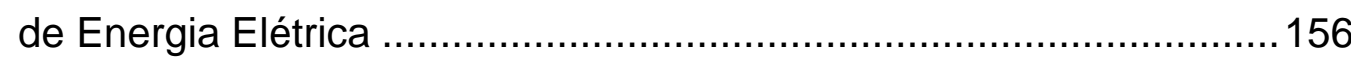

6.3 A necessidade de geração de energia no Espírito Santo e o avanço

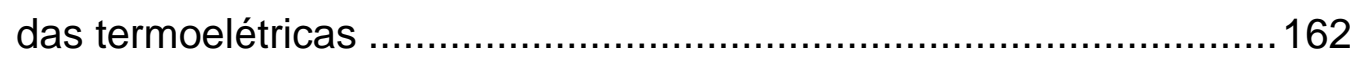

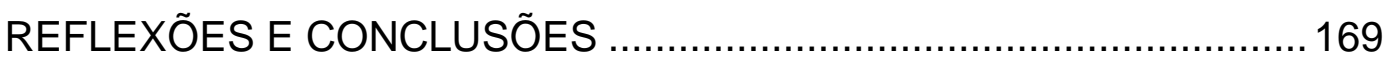

A dependência da política e a necessidade da energia.......................169

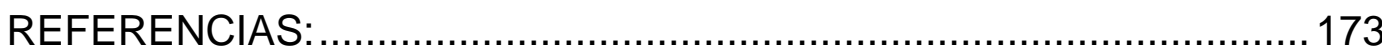




\section{LISTA DE TABELAS}

Tabela 1 - Investimos e o acréscimo de energia entre 1952 e 1957 ........72 Tabela 2 - Incremento da produção de energia elétrica previsto no Plano de Eletrificação do Rio Grande do Sul de entre 1946 e 1969 por matriz.. 84 Tabela 3 - Resultados dos leilões de privatização do setor elétrico (19952000) 142

Tabela 4 - Termelétricas no Espírito Santo 163

Tabela 5 - Geração de Energia Elétrica por Fonte (\%) 164 


\section{LISTA DE GRÁFICOS}

Gráfico 1 - Indicadores de geração de eletricidade em relação ao

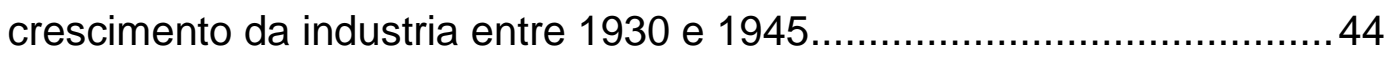

Gráfico 2 - Divisão setorial da economia capixaba 1960 a 1970........... 124

Gráfico 3 - Perfil do endividamento do setor elétrico, por moeda, prazo,

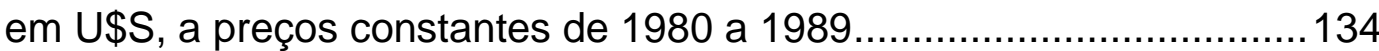

Gráfico 4 - Estrutura de consumo, Escelsa (1995) .............................. 150

Gráfico 5 - Consumo final de eletricidade por setor de atividade .......... 156

Gráfico 6 - Investimento histórico do setor elétrico 1987 a 1997 (em

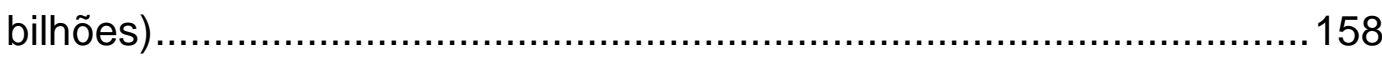

Gráfico 7 - Consumo de Geração local x importação ............................162

Gráfico 8 - Geração de eletricidade por fonte (MWh) .......................... 165

Gráfico 9 - Produção de gás natural no Espirito Santo $\left(10^{3} \mathrm{~m}^{3}\right)$............ 167

Gráfico 10 - Consumo final de gás natural por setor $\left(10^{3} \mathrm{~m}^{3}\right)$............... 167 


\section{LISTA DE SIGLAS}

ABCE - Associação Brasileira de Concessionárias de Energia

ABNT - Associação Brasileira de Normas Técnicas

ACR - Ambiente de Contratação Regulada

ANEEL - Agência Nacional de Energia Elétrica

AMFORP - American \& Foreing Power Company

ANP - Agência Nacional do Petróleo

ANP - Agência Nacional do Petróleo

ARSP - Agência Reguladora de Serviços Públicos

ARENA - Aliança Renovadora Nacional

BANDES - Banco Nacional de Desenvolvimento do Espírito Santo

BID - Banco Interamericano de Desenvolvimento

BNDE - Banco Nacional de Desenvolvimento Econômico

CBEE - Comercializadora Brasileira de Energia Emergencial

CCBFE - Companhia Central Brasileira de Força e Energia

CCON - Comitê Coordenador de Operações do Norte/Nordeste (CCON)

CCOI - Comitê de distribuição da Região Sul-Sudeste (CODI)

CCPE - Comitê Coordenador do Planejamento da Expansão do Sistema

Elétrico

CEMIG - Companhia Energética de Minas Gerais

CEERG - Companhia de Energia Elétrica Rio-Grandense

CEEE - Companhia Estadual de Energia Elétrica do Rio Grande do Sul

CEPAL - Comissão Econômica para a América Latina

CIESP - Centro das Indústrias do Estado de São Paulo

CNAEE - Conselho Nacional de Águas e Energia Elétrica

CNPE - Conselho Nacional de Política Energética

COPEL - Companhia Paranaense de Eletricidade

CODEPAR - Companhia do Desenvolvimento do Paraná

CODI - Comitê de distribuição da Região Sul-Sudeste (CODI)

COFAVI - Companhia Ferro e Aço de Vitória

CODEC - Conselho de Desenvolvimento Econômico (Espírito Santo)

CSN - Companhia Siderúrgica Nacional 
CST - Companhia Siderúrgica de Tubarão

CVRD - Companhia Vale do Rio Doce

DAEE/PR - Departamento de Águas e Energia Elétrica do Paraná

DAEE/MG - Departamento de Águas e Energia Elétrica do Minas Gerais

EDF - Electricité de France

ELFSM - Empresa de Luz e Força Santa Maria S.A.

ELETROBRÁS - Centrais Elétricas Brasileiras

ESCELSA - Espírito Santo Centrais Elétricas

ESKOM - Electricity Supply Commission

EXIMBANK - Export-import Bank (EUA)

FEEP - Fundo de Eletrificação do Estado do Paraná

FINDES - Federação das Indústrias do Espírito Santo

FMI - Fundo Monetário Internacional

FUNRES - Fundo de Recuperação Econômica do Estado do Espírito Santo

FUNDAI - Fundo de Desenvolvimento Agrícola e Industrial

FUNDAP - Fundo de Desenvolvimento das Atividades Portuárias

GERCA - Grupo Executivo de Racionalização da Cafeicultura

IUEE - Imposto Único sobre a Energia Elétrica

MAE - Mercado Atacadista de Energia

MBE - Mercado Brasileiro de Energia

MME - Ministério de Minas e Energia

ONS - Operador Nacional do Sistema

PAEG - Plano de Ação Econômica do Governo

PCB - Partido Comunista Brasileiro

PED - Plano Estratégico de Desenvolvimento

PMDB - Partido Movimento Democrático Brasileiro

PND - Programa Nacional de Desestatização

PR - Partido Republicano

PRP - Partido da Representação Popular

PSD - Partido Social Democrático

PSDB - Partido da Social-Democracia Brasileira

PSP - Partido Social Progressista

PSB - Partido Socialista Brasileiro

PST - Partido Social Trabalhista 
PT - Partido dos Trabalhadores

PTB - Partido Trabalhista Brasileiro

SIN - Sistema Integrado Nacional

UDN - União Democrática Nacional

USELPA - Usinas Hidrelétricas do Paranapanema 


\section{INTRODUÇÃO}

A presente tese se destina a explorar e a refletir sobre as circunstâncias políticas que estiveram na base do processo de eletrificação do estado do Espírito Santo, como parte e etapa do projeto nacional de modernização brasileiro.

Para tanto, serão consideradas a vocação desenvolvimentista que caracterizou o Estado nacional brasileiro durante o século XX, bem como precária situação econômica do estado do Espírito Santo, que tinha características fundamentalmente agrícolas, e se encontrava extremamente fragilizada, ansiando, por agregar uma vertente mais industrial, apontando, assim, para a necessidade de implantação de um setor elétrico.

Muito embora algumas questões - como capacidade hídrica de determinadas regiões, políticas de centralização das plantas geradoras ou acesso a tecnologias -, possam ajudar a explicar a evolução dos setores de energia elétrica, esta pesquisa considerou mais centralmente o peso da dimensão política neste processo, tendo exercido as elites políticas nacionais e regionais importante papel estratégico em seu planejamento, em suas negociações e em sua implementação.

Uma dimensão que não deve ser negligenciada é, por um lado, a forte presença do Estado nacional como fomentador do projeto de modernização do país e por outro lado, as diferentes forças políticas das elites das regiões nacionais, junto as desigualdades das mesmas economias regionais, determinaram a aplicação de distintas políticas para o setor de energia elétrica.

Assim, nos remetendo às análises de Alexandre Saes (2009), podemos dizer que, conjugado com a emergência do processo de industrialização e urbanização nacional, as distintas transformações nos sistemas de eletricidade das diversas regiões do país foram também partes fundamentais da formação do capitalismo nacional.

Ao que nos parece, desenvolvimento estatal nacional, forças políticas regionais e energia elétrica revelam-se em dimensões que assumem sua forma final sob a coordenação do Estado nacional. Nesta perspectiva, sendo impossível dissociar eletricidade e dinâmica estatal, esta pesquisa investigará as especificidades de uma política nacional que se relacionou com características de um ambiente federativo. 
A este respeito, é importante dizer que a história econômica brasileira, assim como os demais países do mundo capitalista, apresenta uma realidade dinâmica que se caracteriza por um processo pendular, que alterna fases desenvolvimentistas de crescimento acelerado e de força do Estado nacional, e fases estabilizadoras, caracterizadas pela necessidade de combater os processos inflacionários e desajustes fiscais, que comprometem o crescimento econômico e a capacidade de fomento do Estado nacional ${ }^{1}$.

Momentos desenvolvimentistas, de maior vigor político e econômico do Estado Nacional, foram propícios à implantação de projetos de desenvolvimento econômico tanto nacional quanto regional. Momentos estabilizadores, de ajuste fiscal e combate à inflação de economias estatais enfraquecidas, são menos propícios à atuação do Estado como fomentador da economia ${ }^{2}$. Dinâmica que historicamente beneficiou a cooptação, sobretudo dos grupos políticos das regiões menos desenvolvidas da federação, para o desenho de um conjunto de ações de políticas econômicas que garantiram o poder do Estado Nacional na medida em que suas relações com o poder central foram de colaboração/ subordinação.

Também, é preciso dizer, que as elites locais que dominaram os aparelhos regionais do Estado $^{3}$, moldaram uma agenda institucional, regulatória e administrativa e garantiram os seus privilégios, mesmo com constantes mudanças de regimes políticos e perspectivas de desenvolvimento econômico.

No estado do Espírito Santo, diferente dos demais estados da região Sudeste, principalmente de São Paulo, onde o capital de comercialização do café durante o início do século XX financiou a industrialização e a modernização econômica, a importância da cultura cafeeira se deu pela particularidade de um modelo econômico e social. Me refiro a uma forma particular de expansão da atividade econômica, ocupação territorial e formação social, baseada na pequena propriedade familiar, nas quais conviviam a economia de subsistência e a produção para geração de excedente.

A industrialização se deu, então, quase que exclusivamente pela necessidade de sobrevivência econômica em decorrência de uma severa crise da cafeicultura, que se arrastaria até o final da década de 1960. Situação que propiciou a

\footnotetext{
${ }^{1}$ RAPOSO, 2011

${ }^{2}$ Idem, 2011.

${ }^{3}$ SILVA, 1986
} 
aproximação entre elites locais afetadas pela crise e elites nacionais que já participavam do percurso da industrialização na administração política Federal. Unidas, para a construção do aparato necessário para sustentar uma infraestrutura de modernização no estado: a energia elétrica.

Podemos perceber que duas questões a este respeito são marcantes. A primeira tem relação com a atuação das elites políticas regionais na implementação da infraestrutura do estado do Espírito Santo. Foram articulações entre as elites políticas capixabas, capitaneadas por Jones dos Santos Neves, junto ao conjunto de forças nacionais que incluíam Getúlio Vargas e Oswaldo Aranha, que permitiram a formação da primeira Espírito Santo Centrais Elétricas S/A (ESCELSA), ainda em 1956.

Neste sentido, podemos tomar como referência as análises de Simon Schwartzman (1979) a respeito da simbiose entre um Estado central, de características patrimonial-burocráticas, e elites regionais oriundas de regiões periféricas da economia nacional, que são dependentes do apoio político do Estado nacional para sobreviver. Tal dinâmica levou à subordinação e dependência dos interesses destes grupos privados a um estamento burocrático.

O jogo político que se desenvolve aí, consiste em um processo de negociação continuada entre a administração federal e administrações regionais subalternas. Este se torna o principal canal para acesso a benefícios e privilégios sob controle do Estado, sendo, inclusive, um dos caminhos mais importantes para a própria manutenção de poder em momentos de mudanças ou rupturas, em um processo de modernização conservadora ${ }^{4}$.

Uma segunda questão importante sobre a modernização capixaba e o papel da energia é o consequente protagonismo do setor elétrico capixaba sob a tutela do modelo de desenvolvimento nacional. A ESCELSA, mesmo sendo fundada em 1956, se tornaria detentora de plena capacidade de funcionamento e investimento apenas em 1968, quando é colocada sob controle da Eletrobrás, com suporte político e financeiro de diversas instituições estatais nacionais, como Banco Nacional do Desenvolvimento Econômico (BNDE), Federação das Indústrias do Espírito Santo (FINDES), Companhia Vale do Rio Doce (CVRD), dentre outras.

\footnotetext{
${ }^{4}$ MOORE JR, 1967; REIS, 1976.
} 
Este agregado de instituições relacionadas ao projeto de desenvolvimento nacional e que se articulam em torno da construção de capacidade operativa de uma empresa pública, caracteriza a formação de uma consciência dos grupos políticos e econômicos - sobretudo industrialistas -, sobre a necessidade da elaboração de um projeto coletivo - e possível - de desenvolvimento capitalista implementado politicamente ${ }^{5}$.

Reforça esta perspectiva as ideias de Renato Boschi (1979), que chamam atenção para os industriais que, ao tomarem consciência da importância desse controle, passariam a se organizar em âmbito nacional numa tentativa de integrar as diversas federações regionais já existentes.

Posto isso, exploraremos nesta tese cinco etapas fundamentais deste projeto coletivo de modernização nacional, em território capixaba. (1) Inicialmente, demonstraremos a materialização deste projeto pela perda de capacidade política da elite relacionada ao café, o que levou à redução da participação deste grupo nas decisões das diretrizes governamentais em termos desenvolvimentistas, abrindo espaço para novas proposições ligadas a dinâmicas urbana e industrial, levando ao que se chamou "consenso de necessidades" entre os vários grupos das elites, em prol da modernização estatal.

(2) Em um segundo momento, analisaremos uma industrialização que se consolida como saída outorgada pela união para o necessário dinamismo da economia estadual, a fim de vencer o "atraso" em relação a outras economias do sudeste. Sendo esta modernização da infraestrutura industrial e de serviços - dentre eles a eletricidade -, voltada para grandes empreendimentos destinados à exportação, como complexos siderúrgicos, extrativista e papeleiro, dentre outros que, de alguma forma, estivessem relacionados aos portos de Vitória e de Tubarão.

(3) Em seguida, já na década de 1970, analisaremos a integração de um sistema nacional de eletricidade, que no Espírito Santo, sob os auspícios da Centrais Elétricas Brasileiras S.A (Eletrobrás), tem início com a realização de projetos de expansão de produção de energia e de eletrificação. Conclui-se o programa de conversão de frequência e é iniciada a interligação ao sistema Centro-Sul, subordinada sobretudo à transmissão e distribuição da Companhia Elétrica de Minas Gerais (CEMIG).

\footnotetext{
${ }^{5}$ GUIMARÃES, 1997.
}

${ }^{6}$ Idem, 2018, p. 53 
Tudo isso, dentro da racionalidade de uma industrialização baseada em empreendimentos de grande envergadura - como no caso da Companhia Vale do Rio Doce (CVRD) e da Companhia de Ferro e Aço de Vitoria (COFAVI), ou mesmo, através de empreendimentos privados nacionais, que tinham algum tipo de relação com a cúpula tecno burocrática do regime militar, como no caso da Aracruz Celulose (hoje Suzano Aracruz) ${ }^{7}$-, que se associava à necessidade de expansão da infraestrutura elétrica. Isto produziu o necessário aporte de capitais públicos ao estado para suplantar todas as necessidades de investimento na ESCELSA e em infraestrutura.

Nota-se, assim, que há claramente uma estruturação do setor de energia elétrica, que privilegia os interesses de investimento estatal em um parque industrial eletrointensivo $^{8}$, ao mesmo tempo em que há uma relação indissociável entre a consolidação de uma infraestrutura elétrica e o processo de modernização estatal. $\mathrm{O}$ resultado acumulado deste cenário se apresenta quando no conjunto das 10 maiores empresas capixabas de 1975, a predominância era das empresas públicas ligadas à infraestrutura, estando a ESCELSA em primeiro lugar.

(4) Porém, enquanto os anos 1980 se relacionam ao avanço das instituições estatais, com uma relativa integração da agricultura capixaba a setores industriais, aumento progressivo de sua participação no total das exportações e importações brasileiras, principalmente com a manutenção de grandes projetos de desenvolvimento, nos anos 1990 observaremos o esfacelamento desse arranjo. Em parte, pelo fraco desempenho da economia brasileira, que reduziu as oportunidades para as economias regionais periféricas - como a espírito-santense -, mas também, pela conjugação de fatores que levaram o país à adesão irrestrita à "nova ordem internacional", cujo interesse em reafirmar a inserção brasileira na economia globalizada sobrepujou as questões regionais mais imediatas.

É dentro deste quadro que, acompanhando o Plano Nacional de Desestatizações (PND), dá-se o primeiro passo para a privatização da Espírito Santo Centrais Elétricas S/A (ESCELSA), com a venda de ativos estaduais da companhia. E mesmo que a venda da empresa de eletricidade não fosse do interesse de todos os atores da elite política capixaba pós-democratização, em um estado que sentia as repercussões econômicas das mudanças em um contexto nacional, a companhia

\footnotetext{
${ }^{7}$ RIBEIRO, 2013.

${ }^{8}$ Setores da economia que usam muita energia.
} 
estatal de seu setor elétrico foi utilizada como forma de arraigar fundos ao erário estadual.

(5) Todo este percurso manteve e reforçou as características históricas da geração de energia no estado do Espírito Santo, principalmente sua dependência no fornecimento de energia do Sistema Interligado Nacional (SIN) ${ }^{9}$, a relação umbilical do setor elétrico com os projetos industriais eletrointensivos e uma produção interna de energia elétrica majoritariamente não renovável, baseada em termoelétricas.

Contudo, é importante dizer que esta não é uma condição exclusiva do território capixaba. Uma parte considerável dos estados brasileiros é dependente do sistema nacional ou de sistemas de outros países ${ }^{10}$ para o seu abastecimento. No ano de 2017, além do Espírito Santo, 10 dos 27 entes federados tinham geração interna provenientes de fontes não renováveis produzidas por termoelétricas ${ }^{11}$. Sendo que destes 10 estados, 9 deles pertencentes à periferia do processo de modernização nacional ${ }^{12}$.

Assim, as questões trazidas por esta tese confirmam a singularidade de se tratar analiticamente o setor de eletricidade brasileiro, e demonstram a necessidade de seu estudo sob a ótica regional. Lógica que se relaciona aos ciclos de um Estado brasileiro, ora desenvolvimentista fortalecido e centralizador, ora, em momentos de crise, menos presente, estabilizador de sua moeda e sob a tutela de um ajuste fiscal $^{13}$.

Evidentemente, tanto estas estruturas que envolvem o encadeamento político no campo energético, quanto as desigualdades do ponto de vista federativo brasileiros são complexas e dificilmente podem ser resumidas em uma grande hipótese. Contudo, entendemos que a partir do que foi apresentado até aqui, é válido um esforço no sentido de mapear e delimitar dinâmicas políticas específicas

\footnotetext{
${ }^{9}$ Segundo dados do balanço energético do estado do Espírito Santo do ano de 2019, fornecido pela Agência Reguladora de Serviços Públicos do Estado do Espírito Santo (ARSP).

${ }^{10}$ Que são os estados do Acre e Roraima.

${ }^{11}$ Os estados nesta situação são: Acre, Amazonas, Ceará, Espírito Santo, Maranhão, Mato Grosso do Sul, Paraíba, Pernambuco, Rio de Janeiro, Roraima, Sergipe. Dados do ONS, 2018 e do Jornal Nexo, 2019. Disponível em: https://www.nexojornal.com.br/grafico/2019/01/21/Qual-o-principal-tipo-deenergia-gerado-em-cada-estado. Acessado em 18 de fevereiro de 2020.

12 Este quadro entra em choque com os números em escala nacional, que apontaram em 2018 para $83,3 \%{ }^{12}$ da produção de eletricidade do país através de fontes renováveis, em sua maioria hidrelétricas. Sem falar, em uma conjuntura mundial, que aponta para o caminho da descentralização da geração de eletricidade, com uma autonomia cada vez maior das regiões dos territórios nacionais.

${ }^{13}$ RAPOSO, 2011.
} 
relacionadas à conformação dos setores de energia elétrica estaduais. Chamaremos este mapa de política da eletricidade.

Para darmos forma a este mapa, teremos 6 capítulos. No primeiro, que se chama "As especificidades do estudo da relação entre política e eletricidade", será apontada a importância dos estudos sobre a eletricidade e sobre sua relação com o Estado. Dentro deste aspecto, indicaremos também alguns dos caminhos trilhados na análise das questões energéticas, aquelas que apontam para a influência do setor de energia para estabilidade, mudança ou ruptura de sistemas políticos nos Estados nacionais.

No segundo capítulo, que tem o nome de: "Eletricidade como projeto de um Estado capitalista entre 1930 e 1946", iniciaremos as incursões nas especificidades do caso do Estado do Espírito Santo. Abordaremos aqui as questões relativas aos primeiros passos da implementação da infraestrutura e institucionalização da eletricidade, acompanhando a assunção de um projeto de Estado capitalista nacional.

Dentro desta conjuntura, apontaremos também para o surgimento das capacidades estatais do Estado brasileiro e a importância da participação das elites políticas, estratégicas e modernizantes, nacionais e regionais, no projeto de desenvolvimento capitalista brasileiro.

No capítulo 3, intitulado "A caracterização de um "Estado-elétrico" entre 1946 e 1964", analisaremos a dinâmica de institucionalização da energia que se direciona para a produção de um federalismo elétrico. Traremos aqui um debate sobre a importância do projeto desenvolvimentista e suas repercussões no contexto federativo, que tem o setor elétrico como um dos grandes alicerces para a industrialização.

Delimitaremos este debate com um panorama sobre a implementação da Energia Elétrica no Espírito Santo e exploraremos também como a Eletricidade se liga ao cenário do desenvolvimento capixaba, se relacionando à construção do que chamamos de um "Estado-elétrico". O que mais chama atenção aqui é o protagonismo das elites políticas locais em articulação com o cenário político nacional, no transcurso do desenvolvimento econômico, que se estabelece entrelaçado à consolidação do setor elétrico capixaba.

Já no capítulo 4, “A lógica centralizadora entre 1964 e 1990”, nos debruçaremos sobre o papel da empresa pública de energia elétrica federal como 
agente modernizador nacional e seus impactos em território capixaba, com os projetos para o setor elétrico, centralizados na administração pública federal e relacionados aos empreendimentos industriais estatais em âmbito nacional, acompanhando a lógica do regime político ditatorial daquele momento.

Com o capítulo 5, "Desestatização e regulamentação sob os auspícios do Estado nacional na década de 1990", discutiremos o processo de desestatização e das reformas implementadas, e os seus reflexos no setor elétrico nacional e no estado do Espírito Santo. A ideia é refletir sobre duas questões: (1) o amplo impacto da desregulamentação do setor elétrico, com a criação das agências reguladoras; (2) a construção das agências reguladoras, como a ANEEL, essenciais para o cenário a partir dos anos 2000.

No sexto e último capítulo, "Da crise de 2001 ao paradoxo atual: entre um projeto de desenvolvimento econômico e a geração de energia elétrica renovável em âmbito regional", encerraremos esta tese abordando a crise de abastecimento de 2001 e sua repercussão nas reformas do setor de 2004, propostas pela gestão do Partido dos Trabalhadores (PT) e a consolidação do Mercado Atacadista de Energia (MAE).

Será importante aqui perceber como se estabelece a relação entre o setor de energia elétrica capixaba e as mudanças que se apresentam a nível nacional e internacional. Apontando, também, para o forte peso da utilização de termoelétricas em um contexto de histórica dependência da energia do Sistema Nacional Integrado (SNI).

Fecharemos este estudo propondo uma reflexão sobre alguns pontos de relevância, destacando as singularidades da política da eletricidade brasileira, que aqui são observadas sob o ponto de vista regional. A seguir, procuraremos destacar os caminhos metodológicos desta pesquisa. 


\section{METODOLOGIA}

Para dar conta do objetivo geral desta tese, esta pesquisa desenvolve um percurso histórico aliado a observações de cunho sociológico e político, o que configura a base de nossa metodologia. Busca-se por este caminho o imperativo da história em seu percurso multifacetado, para, de um lado, identificar as variáveis brasileiras que influenciaram ao longo do tempo a configuração das políticas para o setor elétrico, e de outro, como grande objetivo da pesquisa, destrinchar as dinâmicas políticas que estiveram associadas ao processo de eletrificação do estado do Espírito Santo.

Com isso, fez-se a opção de identificar grandes movimentos, com ênfase nas esferas de atuação das elites políticas e modernizadoras (além de partidos e grupos políticos), levando em consideração a máxima defendida por Renato Perissinoto (2019): "não são apenas as instituições que contam, mas seus operadores também" (PERISSINOTO, 2019, p. 138).

Neste ínterim, realizaremos uma revisão da literatura que respaldará o emprego das análises histórico-documentais e dos dados estatísticos. A respeito da revisão de literatura, buscaremos identificar aspectos estruturais significativos que apontam para uma realidade brasileira sobre o tema, principalmente aquele que aponta: (1) as especificidades do estudo da energia, sobretudo da eletricidade, (2) a singularidade do processo de modernização brasileira, (3) a construção das capacidades estatais, (4) o papel das elites no processo de modernização brasileiro, e (5) as ideias que nortearam a questão federativa e regional no Brasil.

Com relação aos documentos históricos e dados estatísticos, é relevante dizer que, mesmo que a pandemia de COVID-19 tenha dificultado enormemente a coleta de documentos e inviabilizado uma maior amplitude de dados, foram utilizadas informações de diversas fontes, a saber: Centro de Memória da Eletricidade da Eletrobrás, Agência Nacional de Energia Elétrica (ANEEL), Banco Nacional de Desenvolvimento Econômico e Social (BNDES), Centro de Memória da Energia da Eletrobrás, Centrais Elétricas de Minas Gerais (CEMIG) em 1952, Companhia Paranaense de Energia Elétrica (COPEL), Companhia Estadual de Energia Elétrica do Rio Grande do Sul (CEEE), Companhia Central Brasileira de Força e Energia (CCBFE), Companhia Energética de Minas Gerais (CEMIG), Espírito Santo Centrais Elétricas (ESCELSA), Federação das Indústrias do Espírito Santo (FINDES), Instituto Brasileiro de Geografia e Estatística (IBGE), Operador 
Nacional do Sistema (ONS), Agência de Regulação de Serviços Públicos do Espírito Santo (ARSP), Governos Estaduais e Assembleias Legislativas de Espírito Santo, Paraná, Minas Gerais e Rio Grande do Sul, além do Congresso Nacional e algumas de suas Comissões. 


\section{CAPÍTULO 1 - AS ESPECIFICIDADES DO ESTUDO DA RELAÇÃO ENTRE POLÍTICA E ELETRICIDADE}

\subsection{As especificidades da eletricidade}

A importância dos estudos sobre energia - e seus tipos e usos - se explica pelo seu papel na construção da civilização humana. São os regimes de energia que moldam a natureza das civilizações, como elas são organizadas, como o poder político é exercido e como as relações sociais são conduzidas ${ }^{14}$.

E de todas as formas de energia que alimentam o mundo, a eletricidade é talvez a mais difundida. A eletricidade é diferente do petróleo, carvão ou da madeira, pois ela não é uma forma de energia armazenável e não existe na natureza. É uma forma puramente artificial de energia que pode ser produzida a partir de diversas fontes, como energia hidrelétrica, combustível nuclear, energia solar ou eólica.

A energia elétrica, em relação ao petróleo ou carvão, é relativamente fácil de se transportar e transmitir através de grandes distâncias. Entretanto, ao contrário de outros combustíveis, existe uma perda considerável durante a transmissão. Assim, quanto maior a distância que ela precisa ser transportada, maiores são suas perdas.

Outra característica da eletricidade é inexistência de tecnologia para armazenar grandes quantidades. Portanto, a produção e o uso de eletricidade precisam ser cuidadosamente sincronizados: qualquer incompatibilidade entre oferta e demanda cria problemas, desde a potencial instabilidade da rede até blecautes.

A eletricidade também é um objeto imaterial. Ela não pode ser vista, cheirada ou ouvida e, para todos os efeitos práticos, não pode ser provada ou tocada sem que isso represente risco de morte. Podemos ver as plantas, onde a eletricidade é gerada, os fios através dos quais é transportada, os aparelhos ou máquinas que a utilizam e os efeitos que ela tem sobre o corpo. Mas a eletricidade é sempre mediada, e, portanto, é desde o início uma coisa cultural e social. Não somente algo que pertence ao mundo natural, por mais que possa ser interpretado assim.

\footnotetext{
${ }^{14}$ RIFKIN, 2011.
} 
Desde o início de sua utilização em massa, as luzes elétricas abriram outras frentes para consumo, recreação e escolaridade, tornando muito mais seguro os espaços urbanos e o interior das casas. Ao abrir horas extras após o pôr do sol para a vida doméstica, também possibilitaram mais horas de trabalho no chão de fábrica. A eletricidade permitiu o trabalho em turnos, de modo que as unidades de produção pudessem estar abertas 24 horas por dia, facilitando a fabricação de bens e a movimentação de capital ${ }^{15}$.

Por outro lado, quando as infraestruturas elétricas estão funcionando como o planejado, tendem a desaparecer. Canos urbanos que transportam água, resíduos, fios elétricos e fios de telefone e telecomunicações estão todos escondidos dentro das paredes, e tais infraestruturas costumam estar escondidas nas ruas. Elas se tornam visíveis apenas quando quebram ou são substituídas por outras mais modernas.

Ao contrário de carros, geladeiras e aparelhos de televisão, as infraestruturas não devem ser exibidas e estetizadas. Para Akhil Gupta (2015), o que inicialmente diferencia a eletricidade de outras infraestruturas é seu papel na iluminação. A iluminação ajudou a realizar uma certa visão da vida privada, possibilitando a forma particular de domesticidade encontrada na família nuclear, centrada na extensão do dia escolar, na confecção e consumo de refeições em família, no fornecimento de entretenimento e lazer e na regulamentação da fertilidade implícita em todas essas atividades.

No processo que se acentua hoje, o uso da eletricidade se expande para uma gama tecnológica e mesmo para a mobilidade, se pensarmos a expansão da utilização de meios de transporte com motores elétricos. E uma vez que as pessoas já estão de alguma forma conectadas à rede elétrica, o foco das empresas de serviços públicos hoje é garantir a oferta adequada, levando em conta a intensidade crescente de novos usos da eletricidade e de sua relação com os sistemas sociais e econômicos.

Foi a importância da energia no desenvolvimento do capitalismo moderno que estimulou um novo pensamento e incorporou energia nas discussões de economia, política e desenvolvimento social. Uma destas discussões é feita por

\footnotetext{
${ }^{15}$ WOOLF, 1984.
} 
Arjun Appadurai (1996), que chama a atenção para eletricidade como um dos elementos centrais da modernidade.

Appadurai aponta que, com a chegada da eletricidade a lugares antes sem acesso a ela, se inicia uma interação complexa entre as maneiras locais de se fazer as coisas e os múltiplos potenciais de mudança que a eletricidade traz.

Além disso, a sensação de centralidade provocada pela eletricidade é intensificada pelo acesso das pessoas aos meios de comunicação, possibilitado por meio de dispositivos tecnológicos. Podemos dizer que a eletricidade literalmente conecta as pessoas a novas vivências, modifica percepções e visões de mundo ${ }^{16}$.

Podemos afirmar neste sentido que a forma pela qual a eletricidade é gerada, transmitida, distribuída e consumida, modela os arranjos sociais existentes assim como também molda as estruturas políticas, demarcando a relevância das relações historicamente construídas em seu entorno e trazendo para debate a possibilidade de se pensar um poder construído sobre a energia e através da energia. Perspectiva da qual falaremos a seguir, com a análise do conceito de Energopolitica.

\subsection{1"Energopolitica" e a indissociação entre política e energia}

O Conceito de Energopolitica criado por Dominic Boyer (2011; 2019) busca uma genealogia que de conta das dinâmicas políticas que envolvem a energia. Para Boyer, o poder sobre energia - e através da energia - tem sido o companheiro e colaborador do poder moderno, alicerçado tanto por atores políticos estatais quanto corporativos, através do compartilhamento de projetos de formação e transformação política, econômica, social e cultural - como os planos de modernização -.

Observando um cenário contemporâneo, em que boa parte dos Estados buscam a geração de eletricidade renovável e limpa em larga escala, a importância das dimensões materiais e infra estruturais da eletricidade se localiza na possibilidade e capacidade de desabilitar - e habilitar - determinadas configurações do poder político.

Por outro lado, seria possível indagar se os Estados possuem autoridade real e capacidade política para implementar grandes programas de desenvolvimento

\footnotetext{
${ }^{16}$ Neste sentido, Sophie Winther et. al. $(2013 ; 2008)$ faz algumas análises interessante sobre o papel da televisão, e consequentemente da eletricidade, no crescimento do sentimento de inclusão e identidade nacional no Quênia, e no fortalecimento da posição do Islã, na Tanzânia.
} 
nacional que incluam de fato as energias renováveis, por exemplo, em sua agenda de políticas públicas.

Isso porque, pouco se questiona neste caso se, além dos Estados, a própria estrutura política local, sobretudo, aquela que se relaciona com a energia - elites locais, regionais e nacionais, ativistas, partidos políticos, ONGs, jornalistas e representantes de empresas nacionais e transnacionais, entre outros - estão igualmente comprometidos ou são capazes de empreender alguma mudança no modelo dos setores enérgicos.

Nos parece, como veremos ao longo desta tese, que a resistência à transformação da infraestrutura tem menos a ver com a segurança energética, escassez, tecnologia ou eficiência do setor de energia elétrica, e mais com uma dependência entre as complexas relações de poder político constituídas historicamente ${ }^{17}$. Afinal, imaginar uma alternativa à “power grid” é, em essência, imaginar uma alternativa à autoridade política já estabelecida.

\subsection{O Estado como lugar do desenvolvimento energético}

Mesmo que atualmente a ampliação do escopo analítico para a compreensão da ação de atores nacionais e transnacionais, sobre as políticas e escolhas energéticas tenha fugido de uma visão baseada no monopólio do protagonismo do Estado - e das relações interestatais ou internacionais -, o Estado ainda é o lugar de decisão para os setores de energia mundiais. E essa condição persiste porque é o Estado nacional moderno que, ao longo do século XX, vai canalizar e, por vezes, centralizar a potência política e econômica da energia.

Não por acaso, os primeiros estudos sobre política energética foram motivados pelas implicações na segurança nacional dos Estados e a dependência de recursos. Isto porque a demanda das guerras mecanizadas tornou os produtos petrolíferos importantes para a capacidade de competição e para a própria existência dos Estados nacionais. Portanto, governos que controlassem a produção energia dos

\footnotetext{
${ }^{17}$ Uma outra questão relevante tratada por Dominic Boyer é referte, especificamente, às cadeias de suprimento, no caso dos setores elétricos, os sistemas de transmissão de eletricidade, exercem uma influência maciça e oculta sobre sistemas políticos e econômicos. Por este entendimento, a resistência à transformação de infraestruturas tem menos a ver com segurança energética, dificuldades financeiras ou falta de organização institucional, e mais com uma co-dependência política básica. Isso quer dizer que as redes translocais de alta tensão - seja entre Estados nacionais, seja, entre estados dentro de uma mesma federação - e as infraestruturas de combustíveis fósseis, são produtos da concentração política e industrial desde o início do século XX.
} 
seus Estados, que poderiam obter dividendos econômicos ou políticos por meio do poder de mercado.

A algumas décadas atrás, Stephen D. Krasner (1978) e Eric D. Melby (1981) se debruçaram sobre estes interesses de poder e sua relação com os mercados de matérias-primas ${ }^{18}$. Para estes autores, governo e o Estado são os atores mais importantes na conformação e implementação das políticas energéticas. Dentro desta ideia, os formuladores de políticas estatais e os governos têm um conjunto interesses autônomos em relação aos atores socioeconômicos, incluindo a promoção da concorrência no mercado e metas gerais de política interna e externa, para melhorar a segurança do fornecimento de energia.

Neste quadro, à medida que miramos para um sul global - ou também chamada, periferia do capitalismo - a profundidade destas relações tem se estabelecido muitas vezes no escopo da formação dos próprios países enquanto Estados nacionais modernos, após um período colonial, relacionando-se de forma constante com a difusão da industrialização interna e suporte as demandas transnacionais ${ }^{19}$.

Sob este ponto, é importante abordar como referência os paradoxos presentes na África do Sul apresentados por David Mcdonald (2010). Um deles trata da relação entre o abastecimento precário de energia elétrica à população local - em um continente com maior déficit no acesso à eletricidade do mundo - e o atendimento subsidiado pelo Estado, a demanda por energia das indústrias extrativistas locais.

\footnotetext{
${ }^{18}$ Ver mais em Melby EDK. 1981. Oil and the International System: The Case of France, 19181969. New York: Arno e Krasner SD. 1978. Defending the National Interest: Raw Materials Investments and U.S. Foreign Policy. Princeton, NJ: Princeton Univ. Press.

${ }^{19}$ Vale destacar o brilhante trabalho de Timothy Mitchell, Carbon Democracy: Political Power in the Age of Oil (2015). Mitchell relaciona a dependência de combustíveis fósseis com o declínio ou as fronteiras da democracia, analisando especialmente a relação do petróleo com a construção dos Estados do Oriente Médio. Inicialmente, o autor chama a atenção para como o uso do carvão mineral, anterior ao uso massivo do petróleo, possibilitou o surgimento do que ele chama de "democracias do carbono" no século XIX. Através da indústria do carvão, o fornecimento concentrado de energia viajava em redes que ofereciam aos trabalhadores um tipo de autonomia, com o controle e influência sobre os processos produtivos e de consumo. Mas enquanto o carvão ajudou a moldar a democracia moderna, o surgimento e protagonismo do petróleo estabeleceu alguns de seus limites. No curso de sua produção e transporte, o petróleo se misturou consideravelmente e convenientemente com a democracia, transnacionalizando e desterritorializado práticas políticas e as demandas econômicas. Colocando, inclusive, os interesses da indústria do petróleo para além dos domínios dos Estados nacionais e incorporando a lógica do domínio privado das empresas multinacionais aos territórios de extração.
} 
O outro paradoxo, diz respeito à influência da principal empresa de eletricidade do país, a ESKON, na manutenção da segregação racial no regime do Apartheid $^{20}$, e ao mesmo tempo, um dos pilares do processo de desenvolvimento econômico sul-africano pós-Aparheid ${ }^{21}$.

Como veremos ao logo dessa tese, a energia elétrica também ocupa um papel central na propulsão do desenvolvimento e nas dinâmicas de fortalecimento e enfraquecimento de sistemas políticos e sociais no Brasil. E vai ocupar este espaço relacionando-se a um momento de gênese de um país economicamente moderno durante o século XX, com profusão de novas tecnologias, melhoria da infraestrutura urbana, emprego de bens de consumo duráveis e de modos de vida que tiveram como centralidade o consumo da energia em larga escala.

Mas, ao mesmo tempo, será uma modernização conduzida sobre uma sociedade que mantinha as características imperiais, pormenorizando a reforma social para se modernizar ${ }^{22}$, que também se segmentava entre elites regionais transformadas pelo sucesso das exportações agrárias e profundas lacunas no crescimento econômico entre os estados federados.

E este será o caso do estado do Espírito Santo, onde a implementação da energia elétrica fez seguir o roteiro dos interesses das elites capixabas que se encontravam fragilizadas, e que serão coaptadas pelas necessidades existenciais de um projeto de industrialização estatal nacional, que tem início na década de 1930.

É possível dizer que o estabelecimento da energia elétrica é participante da fundação de um tipo de Estado capitalista, em várias das suas faces. Uma destas faces está relacionada à necessidade de um relativo distanciamento do velho padrão colonialista que impedia e limitava o crescimento econômico. Uma outra face baseia-se na ascensão de um movimento modernizante submerso em um contexto

\footnotetext{
${ }^{20}$ Para maior profundidade sobre o tema, pode ser feita a leitura do artigo de Leonard Gentle de 2010: Escom to Eskom: From racial Keynesian capitalism to neo-liberalism (1910-1994). Capítulo 2 do mesmo livro.

${ }^{21}$ Pelo mesmo caminho Sinan Erensü (2018) chama atenção para a estreita relação entre política energética governamental turca denominada Milli Energy - Energia Nacional, tradução livre - de 2017, sob governos consecutivos do Partido da Justiça e Desenvolvimento (Adalet ve Kalkınma Partisi - AKP), e a participação da família do presidente Recep Tayyip Erdogan, através de seu genro Berat Albayrak, Ministro de Recursos Naturais e Energia. Apontando que, além tudo, a energia elétrica pode ser colocada como um projeto de poder familiar.

${ }^{22}$ FAORO, 1992 p. 43
} 
de uma modernização conservadora ${ }^{23}$, em que não se pressupunha ruptura com a antiga configuração estatal de uma sociedade patrimonial estamental, mas apenas a sua reformulação.

Esta conjuntura determinou duas características predominantes do Estado brasileiro: (1) um sistema burocrático e administrativo neopatrimonial ${ }^{24}$, que se caracteriza pela apropriação de funções, órgãos e rendas públicas por setor privados, mas que permaneciam subordinados ao poder central, formando aquilo que Faoro chamou de estamento burocrático ${ }^{25}$. E (2) um despotismo burocrático, quando este tipo de administração se moderniza e segmentos do antigo estamento burocrático vão se profissionalizando e burocratizando ${ }^{26}$.

É a partir deste cenário, que a seguir, buscaremos explorar o palco da implementação da eletricidade no Espírito Santo, localizada neste despertar de uma modernização conservadora e que é permeada pelas características heterogêneas de um aparato estatal em permanente construção.

\footnotetext{
${ }^{23} \mathrm{O}$ termo cunhado por Moore Junior (1975) para analisar as revoluções burguesas que aconteceram na Alemanha e no Japão, em suas respectivas passagens de economias pré-industriais para as economias industriais. A questão central do processo de modernização conservadora é entender como o pacto político entre as elites dominantes condicionou o desenvolvimento capitalista, os levando para regimes políticos autocráticos e totalitários. Poulantzas (1986), ao analisar o caso da passagem da Alemanha para uma economia industrial, corroborou a ideias desenvolvidas por Moore Junior (1975) sobre as revoluções vindas de cima. Portanto, a Modernização Conservadora, e as Revoluções Vindas de Cima, são os momentos em que a revolução capitalista não tem forças suficientes para romper com a classe dos proprietários rurais, tendo como resultado o pacto político entre estas e a burguesia nascente. Tal pacto tem por objetivo manter um projeto de construção de uma sociedade capitalista, mas, mantendo-a arraigada em uma estrutura de dominação, cujo centro de decisão política do Estado mantém os interesses da classe dos proprietários rurais. No Brasil, os grandes proprietários agrários continuaram preeminentes e poderosos durante o Império e a República. Reis (1982) estudou-a durante o período do café, na República Velha, ao passo que Werneck Vianna (1976) se concentrou no período pós-1930, os dois aproximando-se ao conceito de Moore Jr.

${ }^{24}$ Para Hinnerk Bruhns (2012), a diferença entre patrimonialismo e neopatrimonialismo se situa para os autores desse texto no âmbito da relação privado/público. No patrimonialismo, todas as relações entre governantes e governado são de cunho privado, já no neopatrimonialsimo, a distinção público/privado existe apenas formalmente. O exercício "neopatrimonial" do poder se dá em um quadro estatal moderno de tipo legal-racional, que é, portanto, uma definição do neopatrimonialismo extraída dos conceitos de patrimonialismo e de burocracia legal-racional, segundo Max Weber.

${ }^{25}$ Nas palavras de Faoro, "o estamento burocrático comanda o ramo civil e militar da administração e, dessa base, com aparelhamento próprio, invade e dirige a esfera econômica, política e financeira. No campo econômico, as medidas postas em prática, que ultrapassam a regulamentação formal da ideologia liberal, alcançam desde as prescrições financeiras e monetárias até a gestão direta das empresas, passando pelo regime das concessões estatais e das ordenações sobre o trabalho. Atuar diretamente ou mediante incentivos serão técnicas desenvolvidas dentro de um só escopo. Nas suas relações com a sociedade, o estamento diretor provê acerca das oportunidades de ascensão política, ora dispensando prestígio, ora reprimindo transtornos sediciosos, que buscam romper o esquema de controle" (2001, p. 740).

${ }^{26}$ FAORO, 2001.
} 


\section{CAPÍTULO 2 - ELETRICIDADE COMO PROJETO DE UM ESTADO CAPITALISTA ENTRE 1930 E 1946}

\subsection{Espírito Santo: um espelho historicamente isolado do Brasil}

Neste capítulo analisaremos como a eletricidade esteve intimamente relacionada com a construção de um Estado capitalista no Brasil entre as décadas de 1930 e 1946. Uma das questões fundamentais a esse respeito, é como os entes federados construíram algumas características próprias de uma modernização conservadora, que no caso capixaba, esteve relacionado com as especificidades de formação social, política e econômica do seu território.

O estado do Espírito Santo está localizado na região sudeste do Brasil. Circunscrito pelos Estados do Rio de Janeiro, Minas Gerais e Bahia, tem uma das menores áreas do país - 46.077.5 $\mathrm{Km}^{2}$ - representando apenas $0,54 \%$ do território nacional, e a menor população dentre os entes federados da sua região. Caracterizase hoje por um polo produtivo, que conjuga indústria extrativa, agroindústria e indústria de base voltada ao mercado externo.

Contudo, até meados do Século XIX, foi o açúcar seu principal produto, também responsável pelo aparecimento de vilas e povoados habitados, que naquele momento se caracterizava por uma diminuta população, mal se aproximando dos 25 mil habitantes ao findar o período colonial. Tal questão foi impulsionada pelo seu isolamento do restante do Brasil, decorrente de políticas coloniais pombalinas de proteção das Minas Gerais.

Sem dúvida, a proibição de exploração do território capixaba foi o principal marco da historiografia do desenvolvimento e do povoamento do espírito-santense até o final do período colonial. Foi apenas com a transferência da Corte Portuguesa para o Brasil e a permissão de exploração das terras que os primeiros ciclos migratórios, inicialmente internos, chegam ao Espírito Santo.

Nas primeiras décadas de 1800 , a principal problemática para a expansão econômica da Província espírito-santense era a ausência de uma infraestrutura viária que permitisse o trânsito de pessoas e mercadorias entre o Espírito Santo e os 
seus vizinhos ${ }^{27}$. Foi a introdução da cafeicultura, no mesmo período, um grande facilitador para solução dessa problemática, pois esteve relacionada à abertura das estradas e ao processo de colonização do interior do estado.

É importante que se diga que no Espírito Santo a expansão cafeeira processou-se de forma bastante distinta daquela verificada em São Paulo. Três condições foram marcantes para esse processo, levando em consideração as reflexões de Marta Zorzal e Silva (1986).

Em primeiro lugar, temos a localização espacial, com a constituição de duas regiões produtivas distintas: a região sul, polarizada pelo Porto de Itapemirim, e a região central, polarizada pelo Porto de Vitória. A produção da região central, no entanto, era canalizada para a cidade de Vitória, a capital da Província e exportada por seu porto. Este porto, além de oferecer melhores condições para operações de exportação, por permitir o atracamento de navios de maior porte, escoaria, após a Proclamação da República, a produção oriunda dos portos de São Mateus e Santa Cruz, situados ao norte da Província.

Uma segunda condição era o reduzido tamanho da economia do território capixaba, que se aliava ao baixo grau de desenvolvimento de suas forças produtivas, com a quase inexistência de infraestruturas para dinamizar o ritmo das atividades produtivas, o que fez com que a expansão cafeeira no Espírito Santo se processasse em ritmo muito mais lento e em condições muito menos vantajosas do que aquelas existentes em São Paulo.

Ainda assim, o café se torna a maior fonte de recursos do comércio exterior capixaba, representando $94,33 \%$ das suas exportações ${ }^{28}$ nas primeiras décadas do século XX e representaria uma produção superior a um milhão e cem mil sacas, respondendo por cerca de $90 \%$ das rendas do estado até $1924^{29}$. A cafeicultura configura, o principal suporte econômico do Espírito Santo até os anos de 1950, quando os investimentos em infraestrutura denotam o início de uma preocupação por parte do governo estadual na expansão do capital local e no direcionamento de recursos para outros tipos de produção, como a do algodão, açúcar e têxtil, o que se acentua no período da Primeira Guerra Mundial, seguido pelo governo Nestor Gomes (1920-1924).

\footnotetext{
${ }^{27}$ Idem, 2006, p. 133.

${ }^{28}$ BITTENCOURT, 1987.

${ }^{29}$ FORTUNATO, 2011.
} 
A terceira condição distinta entre a expansão da cafeicultura em São Paulo e no Espírito Santo foi seu caráter imigratório, que não foi necessariamente o mesmo. A imigração no Espírito Santo não tinha como principal objetivo suprir um mercado de mão-de-obra pressionado por forte demanda, sua natureza era distinta, bem como foi sua localização espacial, na medida que sua função central era a colonização, sendo direcionado para as áreas despovoadas do território do estado.

Inclusive, levando em consideração esta estrutura de ocupação do território, a estrutura socioeconômica que se consolidou no Espírito Santo durante a vigência da Primeira República, foi a de uma estrutura mista, em que convivia simultaneamente a grande propriedade privada ao lado da pequena propriedade privada. Isso tanto na esfera espacial, quanto produtiva e comercial.

A expansão da pequena propriedade privada, no entanto, se realizou de forma bastante precária e espoliativa. Os imigrantes europeus receberam pequenas frações de terra desprovidas de qualquer infraestrutura, além de não estarem localizadas nas regiões mais férteis. Nessa situação, as carências se faziam presentes, em quase todos os aspectos da sobrevivência humana. Estas iam desde as condições de produção, passando pelo bem-estar social, até as condições de exposição dos seus produtos no mercado, que era bastante precária.

Este cenário reforçava as distâncias entre as elites proprietárias de grandes propriedades e controladoras do fluxo comercial, presentes desde o período colonial, e os imigrantes. Tais dinâmicas, além de disseminar relações servis em seus espaços, impregnava também, com características semelhantes de dependência e subordinação, as demais formas de produção presentes.

Configurou-se, assim, uma estrutura social no território capixaba, formada por elites agrofundiárias e por outras elites mercantis-exportadoras, que fariam um embate político e econômico entre si pela disputa pelo controle do aparato estatal, e que subordinaria a massa dos pequenos produtores camponeses a limites bem estabelecidos de participação política e práticas econômicas de subsistência.

A questão do coronelismo aí, vigente na prática política da Primeira República brasileira, seria uma arma eficiente. Servindo para impedir a emergência de oposições, imprimindo as transformações socioeconômicas em função do instinto preservador de líderes rurais e mercantis exportadores, constituindo-os em pontos de apoio e sustentação política. 
Esta relação de forças também se concebia na estrutura geográfica. $\mathrm{Na}$ região sul, em especial na região de Cachoeiro de Itapemirim, a maior parte dos coronéis era constituída por grandes proprietários de terra que controlavam o eleitorado rural. Interessante, neste aspecto, trazer o depoimento de Carlos Fernando Monteiro Lindenberg, um líder político de família de grande tradição no Espírito Santo.

\begin{abstract}
"[...], mas eu já estava envolvido na vida desde 9 ou 10 anos. Na época, de fazer a política eleitoral, nós éramos chamados pelos candidatos para fazer o Constitui. Era o seguinte: o sujeito passava uma procuração, que dizia: constituo .eu procurador o Coronel Antônio de Souza Monteiro, para fim de alistar Co eleitor e assinava. Fazíamos isso com a letra de meninos de 9 ou 10 anos, justamente porque a letra, ruim, confundia-se com a letra de colonos que, geralmente, não era boa. Assim esse processo passou a chamar-se Constitui, uma que a gente fazia ao Coronel Antônio de Souza Monteiro, meu tio, para alistamento de eleitores. A eleição, também, naquela época, era a bico de pena. $\mathrm{O}$ voto secreto veio mais tarde, após 1930. Por isso, naquela época, somente ganhava candidatos do governo, porque as eleições eram feitas nas antevésperas. E nós fazíamos para meu tio alistar as pessoas"(SILVA, 1986, p. 159).
\end{abstract}

\title{
2.1.1 Primeiros momentos da energia elétrica no Espírito Santo
}

A implementação da energia no Espírito Santo segue um roteiro dede formação de estruturação socioeconômica e política do estado. A primeira usina hidrelétrica do estado pertenceu à empresa pública estadual de Serviços Reunidos de Vitória, fazendo captação de água do Rio $\mathrm{Jucu}^{30}$.

Esta hidrelétrica, foi construída dentro do planejamento do Governo Jerônimo de Souza Monteiro (1908-1912) e movia as bombas do sistema de esgoto e do transporte férreo da capital Vitória. Contudo, o desenvolvimento da energia elétrica no Espírito Santo esteve mais relacionado ao atendimento enérgico do Sul do estado, área industrialmente mais desenvolvida, sendo Cachoeiro do Itapemirim sua maior cidade, que era, também, lugar de nascimento e berço político de Jerônimo Monteiro.

A primeira ampliação da produção de energia elétrica atendeu, assim, a demanda industrial do vale do Itapemirim com a usina de Fruteiras, no rio de mesmo nome, construída pelo governo do estado através de sua empresa de Serviços Reunidos de Cachoeiro de Itapemirim. Os empresários do sul capixaba,

\footnotetext{
${ }^{30}$ Bacia hidrográfica localizada na região Centro-Sul do Espírito Santo, próxima a região metropolitana de Vitória. Hoje, junto com o Rio Santa Maria, uma das principais fontes de abastecimento de água do Estado.
} 
entre as décadas de 1900 e 1930, também foram participantes dos investimentos nos serviços de geração e distribuição de eletricidade ${ }^{31}$, com a Companhia de Eletricidade Muqui do sul e a Usina Hidrelétrica Aparecida, no rio Muqui do Sul, que funcionava com dois grupos de geradores. Outros lugares do estado também operaram neste mesmo contexto.

E é ainda no governo Jerônimo Monteiro que as companhias públicas Serviços Reunidos de Vitória e a Serviços Reunidos de Cachoeiro de Itapemirim, principais empresas de energia da época, foram colocadas nas mãos de empresários privados por falta de capacidade da administração pública em atender à crescente ainda que pequena - demanda.

Porém, poucos anos depois, com o desenrolar do governo Florentino Ávidos (1924-1928) ${ }^{32}$, ocorre a retomada do controle das empresas e a construção de usinas públicas pelos mesmos motivos, mas, desta vez, pela incapacidade de atendimento da demanda destas mesmas empresas privatizadas ${ }^{33}$.

O plano de Ávidos era estimular o crescimento industrial na capital e no Sul do Espírito Santo, por isso, era necessário aumentar a infraestrutura produtiva de eletricidade de modo que a carência de energia não atrapalhasse o surgimento das indústrias previstas pelo governo. O governador atua, então, sob forte pressão popular e da imprensa, para que o suprimento de energia elétrica fosse melhorado e ampliado. A imprensa, inclusive, ajuda a organizar grupos populares que saiam pelas ruas para protestar contra a precariedade dos serviços elétricos da capital.

Mas em 1927, ainda na gestão de Florentino Ávidos, acontece a renúncia aos serviços de energia elétrica por parte do governo estadual, com o Estado transferindo a empresa Serviços Reunidos de Vitória e parte da Serviços reunidos de Cachoeiro de Itapemirim à iniciativa privada, com concessão de exploração por 50 anos. É a General Eletric S/A que se torna a portadora desta concessão, sendo

\footnotetext{
${ }^{31}$ RIBEIRO, 2013.

${ }^{32}$ Florentino Ávidos tem uma longa relação com projetos de energia e infraestrutura no Espírito Santo, especialmente no Sul do estado. Entre 1902 e 1903, dirigiu a construção da primeira usina hidrelétrica do Espírito Santo, destinada a fornecer energia a Cachoeiro de Itapemirim. Poucos anos depois, foi encarregado da construção do último trecho da Estrada de Ferro Sul do Espírito Santo, adquirida pela Leopoldina Railway, entre Cachoeiro e Matilde, que completava a ligação de Vitória à capital federal. Foi também empresário, com uma torrefação de café em Cachoeiro e uma usina de beneficiamento de arroz em Natividade (MG). CPDOC (FGV). Dicionário Histórico-Biográfico Brasileiro On-line: Florentino Ávidos. Rio de Janeiro, 10 out. 2020. Disponível em: http://cpdoc.fgv.br/sites/default/files/verbetes/primeira-republica/AVIDOS,\%20Florentino.pdf

33 Este ciclo de privatização e estatização é persistente e, igualmente, representação de uma conjuntura nacional de pouco investimento estatal na economia, bem como no setor elétrico.
} 
obrigado a ela, o fornecimento da energia elétrica às usinas industriais por preços e prazos previamente definidos.

Todavia, a General Eletric S/A cede seus direitos a CCBFE, empresa do grupo American \& Foreing Power Company (AMFORP), subsidiária para a América Latina do grupo Eletric Bond Share, ambos dos EUA ${ }^{34}$. A CCBFE seria chamada pelos capixabas de Central Brasileira, persistindo assim até 1968.

A CCBFE dinamizou rapidamente o abastecimento de energia, trocando os postes de madeira por postes de ferro fundido e construindo a subestação transformadora para interligação Jucu-Fruteiras. A empresa também incentivou o consumo de eletricidade, vendendo produtos eletrotécnicos e fornecendo crédito a população para a compra destes produtos. É neste momento que os hábitos urbanos começavam a se sobrepor ao hábito rural, principalmente em Vitória.

\subsection{A década de 1930: quando a mão pesada da modernização nacional bate à} porta.

Mas este período, que traz a abertura de novos caminhos para a expansão da infraestrutura de eletricidade no Espírito Santo, não será significativo para retirar o estado de retaguarda das transformações econômicas e sociais do país da época, o que se relacionava, especialmente, à manutenção do poder dos grupos políticos históricos, mesmo em um contexto de rupturas da década de 1930.

Contudo, é importante dizer, que no período anterior à crise do mercado internacional (1929), o Espírito Santo vivenciava um relativo momento de euforia e prosperidade econômica, em virtude da grande expansão da cultura cafeeira. Essa expansão, além de promover uma maior ocupação territorial e aumentar o contingente populacional - dada as características de desenvolvimento da cafeicultura capixaba, já relatadas - permitiu que o estado se projetasse enquanto produtor de café a nível nacional. Isto, por outro lado, também propiciou a realização de um maior aparelhamento da infraestrutura, imprimindo algum ritmo às relações socioeconômicas da região.

\footnotetext{
${ }^{34}$ Ferreira et al. (2012) aponta que a inserção da AMFORP na América Latina se deu antes de sua constituição como empresa. Sua origem remonta ao período de industrialização norte-americana, com a criação da Electric Bond \& Share - resultado da fusão de duas outras companhias, a Edison General Electric Company e a Thomson-Houston - em 1892, subsidiária da General Electric.
} 
Tal ascensão colocaria o Espírito Santo em condições de disputar uma posição de maior destaque na definição da política cafeeira nacional. É exatamente em fins da década de 1920 que as forças políticas do Espírito Santo conseguem se fazer representar nas negociações relativas a uma política de valorização do café nacional. E junto a ascendência no cenário político-econômico do país enquanto partidários da defesa dos interesses agroexportadores, realizariam seus primeiros ensaios de alavancagem ao palco federativo brasileiro.

A seguir, podemos ver como Aristeu Borges de Aguiar, candidato a presidente do Espírito Santo em 1927, introduz o estado aos demais entes federados:

"O Espírito Santo occupa hoje um logar de vanguarda entre os seus irmãos da Federação. Basta dizer-vos que com um território de pouco mais de quarenta mil kilometros quadrados, uma população de cerca de 450 mil habitantes tem uma arrecadação que orça por 30 mil contos de réis, o que lhe confere, sem dúvida, a primazia, entre os demais Estados, na produção per capita. [...] Sómente uma parte do Estado concorre na producção, estando a outra, aliás riquissima, entre o rio Doce e o $\mathrm{S}$. Matheus, com a suas reservas prodigiosas inteiramente intactas, denunciando a sua radiosa e refulgente predestinação, para futuro próximo [...]. (Jornal AGazeta, 1930) $)^{35}$

Se em uma primeira análise, a conferência proferida por Aguiar em comemoração ao bicentenário da introdução do cafeeiro no Brasil realizada em São Paulo em outubro de 1927, caracterizava o momento de ascendência econômica do Espírito Santo, por outro lado, revelava a tentativa de promoção política das elites capixabas no cenário nacional. Mas, de qualquer forma, este evento traduziu o apoio do então candidato Aristeu de Aguiar, que viria a se tornar presidente do estado ${ }^{36}$, à política econômica do então presidente Washington Luiz.

Mas é importante notar que, mesmo com o apoio de Aguiar, como assinala Flavio Calmon Wanick (2007), havia uma forte crítica por parte da elite agroexportadora capixaba, tanto a Washington Luís, quanto a Júlio Prestes ${ }^{37}$, com relação às políticas adotadas desde o crash da bolsa de Nova Iorque e o respectivo impacto no preço do café, o que acaba por corroborar a adoção de características pragmáticas da elite política capixaba, no trato das relações federalistas, já nos

\footnotetext{
${ }^{35}$ Discurso do Presidente do Espírito Santo. Jornal A Gazeta. Vitória, 05 de maio de 1930. Arquivo físico. Acessado em 10/07/2019.

${ }^{36}$ Nomenclatura utilizada para o título de governador de estado na época.

${ }^{37}$ Presidente do estado de São Paulo entre 1927 e 1930.
} 
primeiros momentos da república ${ }^{38}$. Momento em que as forças políticas do estado realizam articulações junto as demais forças políticas da região, para indicação de candidatos à sucessão presidencial, apoiando o candidato indicado por Washington Luiz à presidência da república, Júlio Prestes.

Concretamente, o ano de 1930 no Espírito Santo incorporou o debate político que se colocava no plano nacional, sobretudo, no meio urbano da capital, que não esteve desprovida da guerra entre as elites políticas históricas na disputa do poder regional do estado.

A família Souza Monteiro, cujo maior nome era o ex-governador Jeronimo Monteiro $^{39}$, sai vitoriosa desta guerra. Assim, o Espírito Santo, esteve sob o controle das forças jeronimistas - forças que apoiavam Jerônimo Monteiro. Tais forças foram responsáveis por ditar o sentido atribuído ao movimento e ao golpe no governo nacional de 1930 no estado, desejando, sobretudo, assumir o controle do aparelho estatal.

Contudo, Getúlio Vargas decide-se pelo nome do capitão João Punaro Bley, nome de fora do estado, mas indicado pela Associação Comercial de Vitória ${ }^{40}$.

[...] Punaro Bley, de repente, se viu na incumbência de interventor do Estado. Este aspecto é relevante. Ele chega em 1930, e não era daqui, não conhecia a política local, e teve de valer-se dos elementos que eram revolucionários, os contra Washington Luís. Aqui em Vitória eram: João Manoel de Carvalho, Afonso Correa Lyrio, Fernando de Abreu etc. Ele era manobrado, ora para um lado, ora para outro, porque, além da mocidade e da inexperiência política, ele tinha o desconhecimento específico da política do Espírito Santo. Até que ele tomou pé, já tinha

\footnotetext{
${ }^{38}$ Como analisa Wanick: "Somada à crítica nacional, os protagonistas da política capixaba também estavam amargando investidas constantes. Reportagens cada vez mais contundentes estampavam as páginas do vespertino. Em relação à política nacional, os textos continham trechos fortes e mordazes, como exemplos, "[...] bandalheira eleitoral com que se diz eleito o senhor Prestes [...]", "[...] circopolítico de que vem sendo excellente chefe de picadeiro o sr. Washington Luis [...]", "[...] a mistificação torpe controlada pelo energúmeno sr. Washington Luís [...]”, "[...] que o faccioso, despótico sr. Washington Luís, fazendo vista grossa dos princípios institucionais do regime [...]", entre muitos outros. Causaram-nos espanto a virulência dos adjetivos atribuídos ao supremo dirigente da nação, ao mesmo tempo que nos levaram a considerar, pelo menos em relação à imprensa, a total liberdade de manifestação dentro do Estado. Já no âmbito local, o alvo prioritário era o governo Aristeu e a neófita oligarquia Aguiar. Esta última estava se assenhoreando dos macropoderes estaduais e, não fossem as crises política e econômica, poderia ter-se transformado em uma das mais poderosas do Estado. Críticas fortes também eram feitas ao mandatário estadual: "[...] o sr. presidente Aristeu Aguiar, a grande esperança governamental desfeita para os seus conterrâneos capichabas, [...] desta nossa impagável república de fachada, para que s. exa. e outros desabusados sobas regionais da sua mesma estofa [...]." 24 As questões políticas foram complicadas ainda mais pelo aguçar dos problemas econômico-financeiros. A expansão econômica retrocedeu diante da queda dos preços e da vigorosa contração da demanda internacional pelo café, em virtude, como analisamos no capítulo primeiro, da crise detonada a partir de outubro de 1929, ocasionando, desde então, uma diminuição da receita estadual (WANICK, 2007).

${ }^{39}$ Governador entre 1908 e 1912.

${ }^{40}$ ACHIAMÉ, 2011.
} 
criado uma incompatibilidade com grande parte da população. E além do mais, encontrou uma situação econômica e financeira, dificílima. Cachoeiro de Itapemirim teve uma influência muito grande no segundo governo Bley (1935/43). Porque a permanência de elementos do velho PSD [sic] como Lúcio Mesquita, Fernando de Abreu, Armando Braga, que eram adversários antes da revolução de 30, e foram depois secretários do seu governo, amorteceram [sic] aqueles choques políticos. Cachoeiro de Itapemirim transmitiu, até certo ponto, ao governo Bley, aquele espírito de tolerância que foi a base do governo Fernando de Abreu (Prefeito de Cachoeiro de Itapemirim) ${ }^{41}$

Esta guinada política em 1930, que se dá a partir do nacional, além de um duro golpe para o grupo jonista, foi também o prenúncio de mudanças ainda mais profundas. A primeira delas é relativa à perda de poder de barganha das elites políticas capixabas, que se solidarizavam com as propostas encaminhadas pela burguesia mercantil-cafeeira do centro-sul brasileiro, já que estas estariam deslocadas do centro de comando político do Brasil até pelo menos a metade do século XX.

A segunda mudança se relaciona a acentuação de uma crise econômica e a impossibilidade uma solução a curto prazo. A grande questão que se coloca aí é a reduzida produção de café em relação a produção nacional, ao lado da forma como foi estruturada a produção, principalmente, ao redor com pequenas propriedades privadas e atomizadas. Tal estruturação não permitiu uma maior diferenciação econômica capaz de configurar outras formas de capital que fossem significativas para o estado, o que se tornou um grande problema com a acentuação de uma crise da cafeicultura que se arrastava, criando uma tempestade perfeita para o estado.

Assim, mesmo o Espírito Santo sendo parte integrante da região sudeste e do bloco político e econômico cafeeiro dessa região, que estava na vanguarda das transformações capitalistas nacionais, havia uma correlação sua com o bloco das regiões em que a transformação nas relações de produção pré-capitalistas se processou de forma defasada.

Nesta direção, coadunamos com o diagnóstico de Fernando Achiamé (2010) sobre o impacto dos acontecimentos de 1930 no Espírito Santo. Para ele, assim como para nós, a partir do advento da Revolução, os "anéis" políticos das elites dominantes do estado foram oferecidos para que se preservassem os seus "dedos" econômicos.

\footnotetext{
${ }^{41}$ Entrevista de ex-secretário de Estado da Justiça, ex-deputado estadual da Assembleia Constituinte de 1947 (SILVA, 1986, p. 174).
} 


\subsection{O projeto modernização nacional e o seu vínculo com setor elétrico.}

O movimento que depõe o presidente Washington Luís em 1930 e que impacta o Espírito Santo da forma como acabamos de narrar, cria as condições perfeitas para a acentuação do discurso de industrialização e modernização, que já vinham ganhando espaço nos estados centrais da federação e que acelera nacionalmente com a chegada ao poder de Getúlio Vargas.

Esta mudança se relaciona, antagonicamente, a uma política aplicada sob a economia cafeeira, que permitiu a manutenção da demanda interna e estimulou a indústria a produzir e substituir as importações. Contudo, a hegemonia da atividade cafeeira já não era total a nível nacional, seja pelo ônus que causava ao Estado que financiou a expansão do plantio e que regulava os estoques, seja porque outros seguimentos da economia haviam crescido mais do que o café.

Mas, a diminuição da cafeicultura significava, ao mesmo tempo, o risco de uma crise sem precedentes. Essa cafeicultura estava endividada, especialmente, com os bancos públicos e privados nacionais e, caso quebrasse, arrastaria consigo o nascente sistema financeiro nacional e seu impulso industrializante. É possível dizer, assim, que existia uma dependência morfológica entre cafeicultura e indústria?

Para lidar com essa questão, é necessário pensar em um processo mais amplo no contexto social: a dualidade entre o arcaico e o moderno. Para Gentil Corazza (1981), esta dualidade, muito mais que um conflito, foi uma relação orgânica, sendo uma conjuntura dependente de uma alimentação mútua, sem ruptura e com continuidades, frente ao fato de que as forças que conduziram este processo, na verdade, transformaram o sistema na finalidade de conservá-lo. A elite cafeeira foi, então, a base social de uma elite industrial.

Todavia, esse processo foi eminentemente contraditório, tendo em vista que a acumulação industrial foi impulsionada e limitada pelo café ao mesmo tempo. $\mathrm{O}$ fato é que, o capital cafeeiro gerou os alicerces da indústria, que, por sua vez, teve ampla capacidade responsiva com relação à crise de 1929 - momento em que, oportunamente, a política econômica passou a ter seu eixo principal no câmbio, sendo ajudada com uma carga tributária nacional pequena, o que garantiu o abastecimento interno de máquinas e matérias-primas industriais, com uma crescente demanda por crédito. 
Toda esta conjuntura se torna o motor do desenvolvimento do setor elétrico, que já tinha dado seus primeiros impulsos com entrada de grandes grupos estrangeiros e a formação de grupos nacionais, e que se aprofunda com o transcurso de uma rápida substituição de antigas fontes térmicas de força motriz industrial, como o carvão, pela eletricidade.

A eletricidade foi empregada de forma relativamente rápida, sendo convertida em uma forma de energia utilizável comercialmente, desde sua aplicação inicial nos processos industriais da química, metalurgia, além de usos urbanos nos transportes e iluminação domiciliar. Além disso, com a redução dos custos de produção e aumento da eficiência, a energia elétrica começa a se transformar em um elemento estratégico.

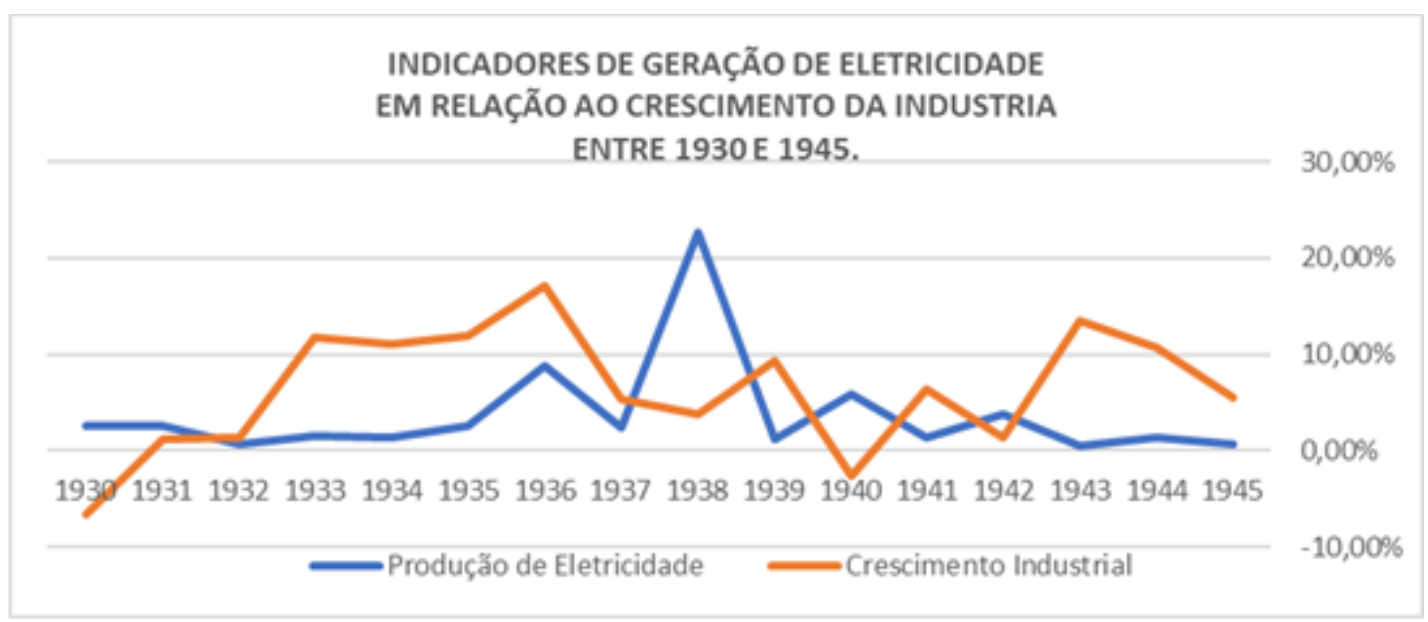

Gráfico 1 - construído com dados extraídos da tabela "Evolução de indicadores econômicos selecionados (1925-1945)", presente em Landi (2006).

Entretanto, como se percebe no gráfico 1, o crescimento industrial que se intensifica em 1930, mesmo que irregular, não essencialmente se traduz em incremento na mesma proporção de produção de eletricidade. Inclusive, mesmo com pequenos picos de alta pode se observar uma baixa constante a partir de 1939.

Ao que nos parece, esta descontinuação tem algumas razões que se relacionam com características peculiares da industrialização brasileira: (1) primeiro, não se construiu sob o comando de um empresariado inovador, do ponto de vista de um desenvolvimento capitalista, se desenvolvendo com base no desdobramento de uma estrutura industrial simples - permeada pelas contradições de uma economia agroexportadora - para uma estrutura mais complexa e avançada; e (2) em segundo lugar, o avanço se deu sob o impacto da ação estatal, dependendo 
de financiamento e planejamento, muitas vezes escassos, durante a segunda guerra mundial, entre 1939 e 1947; e (3) por último, este é um momento de luta, de ascensão e queda na industrialização, sobretudo como luta política, por uma modernização que conservasse o status de um poder patrimonialista, com pouca abertura para rupturas bruscas.

As razões deste descompasso entre crescimento industrial e produção de energia serão um dos fatores impulsionadores da superação de uma fase de "intervencionismo incidental" e onde se inicia a fase do "intervencionismo consciente" $^{42}$, a partir de um Estado centralizado e forte.

A importância da análise desse período em especial está na compreensão do ponto chave pelo qual se desenrolaram os processos de modernização, "pelo alto" que constituirão a formação do Estado brasileiro entre 1930-1960. Sônia Draibe (1985) define magistralmente este período:

\begin{abstract}
"De uma à outra fase da industrialização, com autonomia, força e capacidade de iniciativa, o Estado brasileiro planejou, regulou e interveio nos mercados e tomou-se, ele próprio, produtor e empresário; através de seus gastos e investimentos coordenou o ritmo e os rumos da economia e, através de seus aparelhos e instrumentos, controlou e se imiscuiu até o âmago da acumulação capitalista. Do ponto de vista social e político, regulou as relações sociais, absorveu no interior de suas estruturas os interesses e se transformou numa arena de conflitos. [...] Debilitou as instituições representativas e solapou as formas autônomas de aglutinação e expressão de interesses e conflitos. Manifestou-se como Executivo forte, como aparelho burocráticoadministrativo moderno e complexo e passou a operar através de um corpo cada vez maior e mais sofisticado de funcionários, os novos burocratas, metamorfoseados, nestas circunstâncias, em aparente 'tecnocracia'." (p. 20.)
\end{abstract}

Para Suzigan e Furtado (2006), é neste teatro que os fatores institucionais em sentido amplo, como instituições e políticas públicas, parecem moldar a constituição de regras, condições contextuais sob as quais os mecanismos econômicos e políticos operam, em relação à mudança tecnológica. Porém, a ação do Estado e seu papel dirigente não representam a pura e simples imposição dos interesses dos vencedores para a sociedade. A ação do Estado brasileiro, na medida em que define um projeto de desenvolvimento, quando se coloca um caráter geral à sua política econômico-social, dado que se toma dirigente, modifica a própria correlação de forças que lhe serve de base.

${ }^{42}$ SUZIGAN, 1973. 
Por isso, e através disso, pode-se dizer que o Estado no Brasil não se reduz a implementar os interesses dominantes, mas se constitui de um aparelho com capacidade própria e de uma lógica específica. É possível dizer que existe uma lógica da ação estatal que não se limita a transmitir a lógica do sistema de acumulação, muito menos a reduz à lógica dos interesses dominantes ${ }^{43}$. Seria um arcabouço que se manifesta na medida que imprimi um caráter a sua ação, acima dos interesses de classe sociais, que constituem a sua própria base de sustentação. Um tipo de Estado, então, que se enraíza em uma estrutura social heterogênea, em desequilíbrio, que se erige sobre um conjunto de forças sociais em constante transformação, que vai adquirindo, ao longo do percurso de transição, um aspecto de Estado nacional capitalista muito específico.

É a partir desta logica que o Estado varguista abre caminho para a consolidação de uma tecnoburocracia, sendo os programas, conselhos e comissões técnicas comuns à consolidação do Estado Novo, e cujo pareceres seriam decisivos nos processos de tomada de decisão e para a aglutinação de elites técnicas.

Para Renato Boschi (1979), os intelectuais foram o lócus da prática burguesa e do debate institucional em diferentes momentos. Por isso que os industriais, ao tomarem consciência da importância desse controle, passariam a se organizar em âmbito nacional, numa tentativa de integrar as diversas federações regionais já existentes.

A importância desta dinâmica se caracteriza pela liderança de Roberto Simonsen como um dos atores fundamentais, em um momento incidental na formação de uma consciência industrialista, uma vez que se supera, de certa forma, o imediatismo conjuntural das demandas econômicas, em direção à elaboração de um projeto coletivo e possível de desenvolvimento econômico ${ }^{44}$.

$\mathrm{O}$ industrialismo aparece como um projeto político hegemônico e global, sendo seu lugar por excelência o Centro das Indústrias do Estado de São Paulo (CIESP). Boschi (1979), neste sentido, sugere que o apoio dos industriais ao golpe de 1937 veio da mentalidade intelectual corporativista amadurecida no período, a partir de um histórico de participação na vida política nacional desde os anos 1920.

Por outro lado, é um fato que a entrada da burguesia industrial nos esquemas de aliança política tradicionais foi problemática, sobretudo pela resistência dos

\footnotetext{
${ }^{43}$ CORRAZA, 1986

${ }^{44}$ AQUINO, 2010.
} 
setores tradicionais ligados à oligarquia agroexportadora. Isto porque tal inserção representava o surgimento de novas demandas, que reordenariam as prioridades e diretrizes do conjunto econômico e social nacional ${ }^{45}$. Isto se reproduziu no Estado Novo, quando o estamento militar, em articulação com estas novas elites industriais, proclamaram-se modernizadoras e reformadoras, com a ideia de progresso e desenvolvimento dentro da ordem nacional.

Embora este nacional-desenvolvimentismo tivesse uma função retórica legitimista ${ }^{46}$, ordenadora, ele não pode ser encarado apenas como uma "máscara" da agenda política varguista, mas também como ideário de orientação para certos fins. Neste sentido, pode-se afirmar que Vargas aderia ao ideário nacionaldesenvolvimentista ${ }^{47}$ - e não necessariamente o contrário.

${ }^{45}$ DINIZ, 1978; AQUINO, 2010.
${ }^{46}$ BASTOS, 2007.
${ }^{47}$ É possível dizer que o “desenvolvimentismo”, segundo Fonseca (2015), vai se localizar entre duas dimensões do ponto de vista epistemológico: (1) um conjunto de práticas de política econômica propostas e executadas pelos formuladores de políticas que compartilham um núcleo comum de atributos que os caracteriza como tal e (2) um conjunto de ideias que se propõe a expressar teorias, concepções ou visões de mundo. Esta polissemia na busca da construção de tipo ideal mundo foi utilizada por vários autores para conceituar não propriamente desenvolvimentismo, mas Estado desenvolvimentista, que Jose Medina Echevarría (1964) denominou "mecanismo essencial" para a superação do subdesenvolvimento. Logo, o conceito foi utilizado indiretamente para designar um conjunto de atributos caracterizadores da política econômica de determinados governos de um sul global. O desenvolvimentismo aparece na literatura tanto referindo-se a um fenômeno da esfera do ideológico, como para nomear práticas históricas de política econômica associadas a um Estado característico. A primeira referência de "Estado desenvolvimentista" pode ser encontrada em Cardoso e Faletto (1970), entre o final da década de 1960 e o início da década de 1970. Todavia, a caracterização de "Estado-desenvolvimentista" já aparecera antes com Hélio Jaguaribe (1962) na obra Desenvolvimento econômico e desenvolvimento político. E posteriormente em Bresser-Pereira em 1963 e 1968, que o caracteriza como choque do desenvolvimentismo intervencionista e uma ideologia com o objetivo de desenvolvimento econômico. Esta "Ideologia desenvolvimentista" consta nas análises de Celso Furtado (1961, p. 216), mesmo que a ideia de desenvolvimentismo não apareça em sua obra. Segundo Furtado, o "desenvolvimentismo" é uma forma de conservadorismo, pois parte da premissa de que as estruturas econômicas e sociais que se formaram na Europa, desde a Revolução Industrial, e que estão indissoluvelmente ligadas ao capitalismo, podem ser transplantadas para a América Latina. Se não se considera o estruturalismo, a classificação que me parece corresponder ao meu pensamento é a de "nacionalismo reformista" (Arquivo Celso Furtado, 1970). Próximo a Furtado, é Echevarría (1964) que se aprofunda nos aspectos chave para a consolidação e a continuidade das políticas desenvolvimentistas: (1) atores, grupos sociais e políticos, e suas organizações como empresários, intelectuais, burocracia estatal, elite política, operários e classes médias; (2) adoção por parte deles de uma visão de mundo desde do ideário do desenvolvimento, e por último; (3) força política para canalização dos seus anseios e os verem materializados como política econômica. Mas é possível dizer que no Brasil é a Ricardo Bielschowsky (1988) a quem se deve a formulação mais precisa do conceito de desenvolvimentismo como ideologia. Segundo ele, o desenvolvimentismo é (1) onde a industrialização integral é a via de superação da pobreza, (2) não sendo possível uma industrialização eficiente e racional através do mercado, sendo necessário que o Estado (3) planeje e defina a expansão desejada dos setores econômicos. (4) Tendo este mesmo Estado que ordenar a expansão, captar a orientação e ordenar os recursos financeiro, onde a iniciativa privada for insuficiente. Ao longo dos desdobramentos intelectuais sobre a ideia, é importante apontar para as análises comparativas de Sergio Schneider 
Dada esta definição geral dos interesses nacionais, as formas e os objetivos particulares da intervenção nacional-desenvolvimentista mudariam ao longo dos momentos em que Vargas esteve no poder.

Mesmo que a siderurgia fosse central no modelo de desenvolvimento desde a década de 1930, a ênfase na industrialização pesada e na infraestrutura de base aumentou ao longo do tempo, à medida que gargalos na oferta de energia e insumos básicos ameaçavam afetar a continuidade da expansão industrial e diversificação econômica.

Este cenário se relacionava, de uma forma geral, com o sucesso na disseminação da energia como força motriz, que levou a um cenário comum de escassez e racionamento até a década de 1940. Assim, a intervenção nacionalista no setor não era apenas fruto dos objetivos do desenvolvimento proposto pela modernização, mas resultaria de choques entre interesses definidos como nacionais no âmbito da política de Estado e os interesses constituídos na lógica do capital industrial privado.

Nestas circunstâncias, a participação da energia no contexto nacional entre 1930 e 1946 foi marcada pelo enfraquecimento do mercado privado como ator político e econômico preponderante e pela assunção do Estado como principal investimento e organização do setor. A dinâmica de interação entre Estado e mercado foi determinada: 1) pelo fracasso das tentativas de regulação do mercado; 2) pelos obstáculos para mobilizar recursos para empreendimentos estatais.

O protagonismo de empreendedores privados nacionais no setor elétrico era pouco realista, dadas suas limitações no campo financeiro e de tecnologia. Já a intervenção por meio de estatais, por outro lado, envolvia custos econômico e políticos consideráveis, não apenas por entrar em choque concessionárias estrangeiras e seus governos ${ }^{48}$, mas também por exigir a concentração de recursos financeiros significativos no Estado nacional. Para um governo que foi consolidado

(1999) da experiência histórica do Brasil e do México, que aprofunda a conceituação do desenvolvimentismo, caracterizando o Estado-desenvolvimentista nestes países: (1) capitalismo político, uma vez que investimentos e lucros são construídos a partir de decisões estatais; (2) defesa do desenvolvimento e da necessidade do Estado; (3) exclusão política da maioria da população adulta; (4) burocracia fluida e fracamente institucionalizada.

${ }^{48}$ Alexandre Saes (2009) narra o conflito entre o polvo canadense (Light) e o Minotauro de santos (Doca de santos) pelo controle do mercado de energia em São Paulo entre o final do século 19 e as primeiras décadas do século 20. 
politicamente e economicamente de forma gradual, com idas e vindas, a opção estatal não podia ser a inicial.

Paulatinamente, a primeira ação do governo, seguindo a guinada ao controle estatal, foi a de barrar o processo de concentração do setor, impedindo transferências ou as promessas de transferências, de exploração de cursos e quedas d'águas em setembro de 1931, alegando a preparação em curso de um Código de Águas e buscando evitar "operações, reais ou propositadamente simuladas, que dificultem oportunamente a aplicação das novas leis ou frustrem a salvaguarda do interesse do país"49.

Destacaram-se também, em 1931, a retirada da competência dos municípios para autorizar a exploração da energia hidráulica que passava a ser uma concessão da União; em 1933. Antes mesmo da promulgação do novo Código, em meados de 1934, o governo interveio sobre a liberdade contratual das concessionárias, eliminando a cláusula-ouro, primeiro marco regulatório do setor elétrico, em que a energia potencial dos cursos d'água tornou-se um bem autônomo suscetível de apropriação, determinando que a revisão tarifária se realizasse a cada três anos ${ }^{50}$.

Em 10 de julho de 1934 é promulgado o Código de Águas ${ }^{51}$, às vésperas da Constituição do mesmo ano, com as seguintes delimitações: 1) o fim do direito de acessão, que dava ao proprietário da terra a propriedade também sobre os cursos e quedas d'água; 2) concentração do poder concedente de uso para o governo federal, retirando poder de estados e municípios; 3) revisões contratuais para o respeito ao princípio de "custo pelo serviço".

Em um aspecto geral, se separa o potencial de energia elétrica do direito de propriedade às margens dos rios. Neste sentido, a energia elétrica, especialmente aquela obtida por fonte hidráulica, se torna um novo bem público que só poderia ser explorado em conjunto ao Estado.

Novos avanços no campo da nacionalização do setor elétrico se dão com a constituição de 1937, que reacomoda a legislação às restrições econômicas e políticas existentes. A Constituição reforçaria o nacionalismo da legislação varguista ao definir que novas concessões só poderiam ser feitas a brasileiros ou empresas constituídas por acionistas brasileiros. Contudo, estas regras foram

\footnotetext{
${ }^{49}$ Decreto 20395, de 15 de setembro de 1931.

${ }^{50}$ Decreto 23501, de 27 de novembro de1933.

${ }^{51}$ Pode ser acessado em: http://www.planalto.gov.br/ccivil_03/decreto/d24643.htm
} 
atenuadas pelo Decreto $852 \mathrm{em} 1938^{52}$, permitindo a estrangeiros a possibilidade de ações sem direito a voto, e pela Lei Constitucional n. 6 de maio de 1942, que autorizou o aproveitamento de novas concessões por empresas estrangeiras, diante do cenário de racionamento daquele ano $^{53}$.

Surgiram também, neste período, as primeiras agências voltadas para a regulamentação da produção industrial de energia elétrica, como o Serviço de Águas do Ministério da Agricultura em 1934. A primeira associação de classe do setor elétrico, a Associação Brasileira de Concessionárias de Energia (ABCE), que representa as empresas concessionárias de energia elétrica, surgiria em 1936, e, em seguida, o Conselho Nacional de Águas e Energia Elétrica (CNAEE), organizado em 1939 e subordinado a presidência da república.

Não obstante, o governo estadonovista procurou regular as atividades empresariais privadas de acordo com interesses definidos como nacionais pela política estatal. Por outro lado, se a regulação do mercado não se mostrasse viável para induzir os investimentos desejados, a alternativa de intervenção direta por meio de empresas estatais só se viabilizaria com recursos financeiros cuja mobilização era política e economicamente custosa. Por isto, não só na energia elétrica, mas na siderurgia e no ramo do petróleo o governo Vargas procurou explorar como oportunidades de barganha de fundos públicos externos para desenvolver os ramos básicos, antes de recorrer à formação de fundos financeiros locais destinados a empresas estatais.

52 Pode ser acessado em http://www.planalto.gov.br/ccivil_03/decreto-lei/19371946/del0852.htm\#: :text=Cabe\%20a\%20execu\%C3\%A7\%C3\%A3o\%20deste\%20decreto,em\%2 0que $\% 20$ este $\% 20$ se $\% 20$ transformar.\&text=Este $\% 20$ decreto $\% 2$ Dlei\%20entrar\%C3\%A1\%20em,re vogadas\%20as\%20disposi\%C3\%A7\%C3\%B5es\%20em\%20contr\%C3\%A1rio.

53 É importante analisar que as características das empresas de serviços públicos - geração, transmissão e distribuição de eletricidade, por exemplo - foram tradicionalmente vistas, durante boa parte do século XX, como monopólios naturais a serem controlados pelo Estado, ou mesmo regulados, quando concedidos, e ficavam nas mãos de firmas privadas. No último caso, a empresa pode pertencer ao setor privado, mas a produção é regulada por um órgão ou uma comissão do governo. Um outro modelo é quando uma concessão é outorgada pelo Estado por um período finito, onde a empresa privada de serviços públicos não envolve qualquer propriedade privada, mas sim, é uma empresa privada prestando um serviço específico. Segundo Guislain e Kerf, neste caso: “[...]o Estado delega ao setor privado o direito de prestar um serviço, embora retenha algum controle sobre o setor, ao incorporar em um contrato de concessão ou licença os termos de referência e as condições (inclusive os direitos e as obrigações do prestador do serviço) que regerão o projeto de infraestrutura." (1996, p. 101). Um contrato de concessão inclui determinações sobre as tarifas a serem cobradas, sobre o método pelo qual podem ocorrer reajustes periódicos, além de também incluir disposições relativas a investimentos para modernizar e ampliar os serviços específicos que constituem o objeto do contrato (BAER e MCDONALD, 1997). 
O cenário, então, vai se determinando, pela passagem de um sistema de pulverização na produção e distribuição de energia para, da mesma forma que nos outros segmentos da administração pública, ir, aos poucos ${ }^{54}$, para um sistema centralizado e fundado na empresa estatal.

A intervenção progressiva no setor elétrico mostra que o nacionaldesenvolvimentismo podia ser flexível, oportunista e politicamente realista embora a influência do movimento tenentista de escopo nacionalista não possa ser desprezada, na figura de Juarez Távora, que foi diretamente atuante na regulação do setor como ministro da Agricultura ${ }^{55}$ - dada a dificuldade de regular o mercado segundo sua ideia e de mobilizar recursos locais para empreendimentos estatais.

As estratégias, neste sentido, podiam variar em função das conjecturas que seriam necessárias para alcançar os resultados pretendidos com diferentes formas de barganha externa, fosse por meio de filiais de empresas estrangeiras ou de recursos públicos.

No caso específico do setor elétrico, quando a barganha internacional pareceu não assegurar a realização dos objetivos, Vargas não hesitou em denunciála com a retórica de confronto aos interesses de Estado e à expansão de sua intervenção direta na economia.

Ao final, podemos dizer que os períodos entre 1930 e 1946 destaca-se como o momento do desenvolvimento do setor, sua evolução institucional, jurídica e o progresso técnico do setor elétrico, muito mais do que o aspecto produtivo. Tendo, inclusive, como ponto de partida, as relações entre racionalidade legal e técnica, com as estratégias referentes às permissões para exploração dos recursos energéticos e uma intervenção da administração pública nos contratos dos serviços de eletricidade dos empreendimentos de geração, transmissão e distribuição de energia estatais.

\subsection{Eletricidade e o impacto da modernização no contexto capixaba no pós-} 1930.

Voltando à análise do Espírito Santo, o estado chegará ao fim da década de 1930 com um relativo dinamismo social e algum desenvolvimento industrial. Em 1940, o estado alcançaria uma população de 750.107 habitantes, um crescimento de

\footnotetext{
${ }^{54}$ Estas mudanças no setor elétrico duram duas décadas mais para se consolidar.

${ }^{55}$ BASTOS, 2007.
} 
aproximadamente $60 \%$ com relação ao início da década de $1920^{56}$. Este aumento populacional considerável era reflexo das mudanças econômicas que se colocavam, sobretudo através do crescimento urbano ${ }^{57}$. Isto acompanha um cenário nacional de desenvolvimento industrial, que tem como um dos seus primeiros projetos estatais a Companhia Vale do Rio Doce (CVRD $)^{58}$, bastante importante no contexto da modernização capixaba.

A CVRD foi fruto de acordos entre os governos do Brasil - capitaneado por Getúlio Vargas -, da Inglaterra e dos Estados Unidos da América, para viabilizar um suprimento de minério de ferro às forças armadas aliadas durante a Segunda Guerra. Pelo acordo, ao Brasil caberia desapropriar a Estrada de Ferro VitóriaMinas $^{59}$ e liquidar todos os débitos e hipotecas. Aos ingleses coube indenizar a desapropriação da concessão das minas de ferro da Cia. Itabira de Mineração, que seriam incorporadas à CVRD. E o Export-Import Bank (EXIMBANK), dos Estados Unidos da América, seria designado para financiar US\$ 14 milhões em créditos para compras de equipamentos e materiais necessários às obras de reestruturação e ampliação da Estrada de ferro, para a expansão e conclusão das obras do cais de embarque do porto de Paul - município de Vila Velha, região metropolitana de Vitória - e para a extração do mineral nas jazidas em Minas Gerais.

Para atender esta demanda, além do crescente consumo dos 32 municípios existentes no Estado, o setor elétrico capixaba contava com 44 pequenas empresas que operavam 45 usinas geradoras. A maior e mais expressiva empresa continuava sendo a CCBFE, empresa constituída nos anos 1920 responsável por fornecer $92,11 \%$ da força e $74,32 \%$ da energia gasta na iluminação das cidades capixabas entre 1940 e $1960^{60}$.

Foi ainda com código de águas, promulgado em 10 de julho de 1934, que se conseguiu dar alguma organização ao aproveitamento dos recursos hidráulicos e a indústria de energia no Espírito Santo, normatizando igualmente a política de

\footnotetext{
${ }^{56}$ Censo Demográfico 1872, 1890, 1900, 1920,1940, 1950, 1960,1970, 1980,1991, 2000 e 2010. IBGE, 2010. Disponível em: https://censo2010.ibge.gov.br/sinopse/index.php?dados=4\&uf=00 Acesso em: 04/05/2020.

${ }^{57}$ Mas sem abalar a sua dependência da cafeicultura, em termos econômicos, políticos e sociais, que seria uma forte influência até a década de 1960.

${ }^{58}$ A Companhia Vale do Rio Doce foi criada em 1 de junho de 1942 em Itabira, Minas Gerais.

59 Criada em 1904, sendo inicialmente uma ferrovia privada, construída para o transporte ferroviário de passageiros e para escoar a produção cafeeira entre o Vale do Rio Doce e o Espírito Santo. Em 1908, sua foto foi alterada, passando a escoar o minério de ferro extraído no município mineiro de Itabira até os portos do Espírito Santo.

${ }^{60}$ RIBEIRO, 2013, p. 45.
} 
concessões. Neste quadro, Cachoeiro do Itapemirim, possuidor de maior quantidade de unidades industriais do que Vitória, e que estabelecia maior influência na política capixaba, foi também o maior beneficiado com a expansão dos serviços de energia elétrica.

Em Vitória, os maiores consumidores seriam serrarias beneficiadoras de café, as fábricas de tecidos Jucutuquara Industrial Ltda, fábrica de gelo e oficinas, como as áreas operacionais mecânicas das indústrias e das empreiteiras de obras no Porto de Vitória e da Companhia Estrada de Ferro Vitória-Minas. Já em Cachoeiro de Itapemirim seriam atendidas quatro serrarias de madeira e três fábricas, uma de tecido, outra de cimento e uma de açúcar, que utilizavam energia elétrica. Todo este consumo, tanto na capital quanto em Cachoeiro, também era fornecido pela CCBFE.

Entretanto, a expansão industrial e comercial associada à indução do consumo residencial extrapolava a capacidade de geração. Juntos, os maiores consumidores de Vitória utilizavam $2314 \mathrm{CV}$ fornecidos pela CCBFE, enquanto o consumo de Cachoeiro de Itapemirim ultrapassava 3342 CV.

É em 1941 que o sistema de geração da CCBFE começa a dar os seus primeiros sinais de deficiência. A demanda média anual de energia na zona de concessão da CCBFE, que correspondia a 32,89\% da população capixaba e compreendia a zona mais dinâmica da sua economia, aumentou, sem que empreendimentos de geração acompanhassem a demanda.

Tendo em vista este quadro, o segundo interventor federal escolhido por Getúlio Vargas, Jones dos Santos Neves ${ }^{61}$ (1943-1945), inclui na tríade de planejamento da ação de seu governo, que incluía saneamento, produção e transportes, um programa para enfrentar a crise no abastecimento de energia.

Tinha-se, para tanto, a convicção de que a CCBFE não daria mais conta sozinha dos investimentos necessários em novas usinas de geração de energia, e

\footnotetext{
${ }^{61}$ Jones dos Santos Neves nasceu em São Mateus (ES), norte do estado em de 1901. No início de 1933 participou da comissão diretora provisória do Partido Social Democrático (PSD) do Espírito Santo, criado com vistas às eleições à Assembleia Nacional Constituinte, convocadas pelo presidente Getúlio Vargas. Em 21 de janeiro de 1943, Jones Neves foi nomeado interventor federal no Espírito Santo, assumindo o cargo no mesmo dia em substituição a Punaro Bley. Em 1945 Jones Neves elegeu-se senador pelo PSD. Assumindo o mandato em abril de 1947, participou da Comissão de Finanças do Senado e das comissões mistas de Investigação Agrícola e de Leis Complementares. Nesse período, foi também presidente do diretório regional do PSD em seu estado e membro do diretório nacional do partido. Em 1950 elegeu-se governador do Espírito Santo na legenda da coligação entre o PSD e o Partido Trabalhista Brasileiro (PTB).
} 
que o modelo estadual de fornecimento estava no seu limite. Contudo, tanto o governo estadual quanto o federal relutavam em fazer investimentos em empreendimentos de eletricidade de grandes dimensões, uma vez que as receitas do Estado durante a segunda guerra mundial, e depois dela, estavam limitadas a sua capacidade de endividamento e às oscilações do preço do café.

Mesmo assim, as diretrizes de Neves eram claras e anunciavam um novo tempo para ação estatal e para a responsabilidade sobre a infraestrutura elétrica capixaba:

\begin{abstract}
"Os novos tempos nos ensinam que o Estado é a função das condiçães econômicas que predominam em sua organização social. Daí a necessidade imperiosa de fortalecer as suas forças econômicas e racionalizar a sua administração." 62
\end{abstract}

A necessidade de um projeto modernizador já era representada de forma clara na fala do governador Jones do Santos Neves, que também chama atenção para a inevitabilidade da construção de um aparato estatal que desse conta deste arranjo. Daí, duas questões parecem emergir como condições essenciais do projeto modernização brasileiro: primeiro, a formação das capacidades estatais e depois o papel das elites modernizadoras. Questões que serão tratadas a seguir.

\title{
2.4.1 As capacidades estatais
}

Tomando Max Weber (1978) como referência, é possível dizer que a centralidade do Estado é necessariamente acompanhada pela construção de uma "capacidade estatal" de intervir de forma efetiva no contexto social, político e econômico. Por sua vez, esta capacidade estatal se dá pela existência de uma burocracia profissionalizada e de uma coordenação interestatal ${ }^{63}$.

Para tal, como se expressa no eixo da modernização brasileira e capixaba, torna-se necessária a existência de uma administração pública profissionalizada e qualificada que seja capaz de interpretar a realidade social e econômica local e de dar conta das dinâmicas políticas coerentes ${ }^{64}$. É importante apontar aí justamente para as especificidades heterogêneas do Estado brasileiro, sob o ponto de vista federativo.

\footnotetext{
${ }^{62}$ RIBEIRO, 2013, pg. 72.

${ }^{63}$ RUESCHEMEYER E EVANS, 1985.

${ }^{64}$ SKOCPOL, 1985.
} 
A percepção da heterogeneidade dentro do Estado manifesta-se nas discussões sobre como o arranjo estatal brasileiro combinaria princípios do Estado racional legal com normas informais que seriam permeadas por sistemas de patronagem e que centralizariam recursos políticos e econômicos, com a finalidade de maximizar ganhos privados.

Neste ínterim encontram-se os estudos sobre os bolsões de eficiência ${ }^{65}$, caracterizado pela existência de ilhas de burocracias racionais-legais que conseguem se isolar da política de patronagem, que são características apropriadas por uma larga literatura sobre o tema, para explicação das heterogeneidades do contexto brasileiro.

Essas capacidades estatais, então, são vistas por um enfoque sistêmico que posiciona organizações estatais no entorno de vários níveis, atores e influências, que atuam em intensa interdependência. A capacidade estatal passa a se relacionar com a perspectiva da governança e da construção de redes entre organizações do setor público, privado e organizações não-governamentais, que passam a ser fundamentais para a administração ${ }^{66}$.

É possível dizer, portanto, que a análise da capacidade do Estado brasileiro em formular e implementar políticas desenvolvimentistas devem ser pensadas a partir do arranjo político-institucional, que compreende "[...] o conjunto de regras, mecanismos e processos que definem a forma particular como se coordenam atores e interesses na implementação de uma política pública específica" (PIRES E GOMIDE, 2014, p. 7).

2.4.2 A importância das elites modernizantes e estratégicas no contexto do desenvolvimento brasileiro.

As elites podem ser consideradas como os principais atores na construção das capacidades do Estado brasileiro. Mesmo que no contexto brasileiro atual estes grupos tenham se transformado em algozes da vida política nacional ${ }^{67}$, o seu

\footnotetext{
65 EVANS, 1989.

${ }^{66}$ Peter Evans (1993), que classificou o Brasil como um Estado que possuía uma administração que se aproximava em vários aspectos das burocracias predatórias, onde predominava a patronagem e o clientelismo. Mas onde, também, bolsões - ou ilhas - de eficiência, representadas por burocracias profissionalizadas que se aproximam a administrações dos Estados desenvolvimentistas.

${ }^{67}$ RAPOSO, 2019.
} 
impacto sobre o crescimento e o desenvolvimento econômico transborda a sua representação na sociedade.

A razão disso é o controle destes agentes políticos e econômicos sobre os ativos produtivos e as instituições, o que lhes permite influenciar tanto na alocação de autoridade, quanto na alocação de recursos. Ainda que haja influência de outros grupos de pressão e de políticas, as elites tomam a maioria das decisões mais relevantes e esboçam virtualmente quase toda legislação, controlam o orçamento nacional e são a fonte da maior parte de inovações em políticas públicas. E será, também, uma das principais características de uma Estado desenvolvimentista, com a expansão de uma burocracia por mecanismos institucionais comandada por estes atores que conduzirá a um permanente diálogo com os setores econômicos estratégicos e organizados da sociedade em que atua.

A esse respeito, é após a Revolução de 1930 que se inicia no Brasil um caminho de construção institucional vigoroso com vistas a uma certa racionalização administrativa e ao desenvolvimento econômico. Agências estatais previamente existentes, como o Itamaraty e o Banco do Brasil, foram postas a serviço destes dois objetivos, contribuindo para a formação de técnicos competentes dedicados a pensar a modernização econômica.

Assim, a construção de uma burocracia coerente e a inserção social são duas faces da atuação de uma elite que mais se relaciona com o processo de modernização. E que impedem, por um lado, que o isolamento se transforme em despotismo burocrático e descambe para o Estado predatório e impedem, por outro, que a inserção na sociedade leve o Estado a ser apropriado pelos grupos econômicos e sucumba ao clientelismo e à privatização.

Paradoxalmente, ao contrário de uma a burocracia coerente e da inserção social, o sistema político brasileiro que vai se estabelecer no pós-30, mesmo desestabilizado pelo contexto de rupturas da época, conserva seu núcleo de bases agrárias tradicionais que são absorvidas pelo Estado graças à centralização política no contexto de transformação econômico-social ${ }^{68}$.

Nestas circunstâncias, a sociedade que conserva é a mesma que se transforma, e o sistema de poder se parte em várias partes, introjetando conflitos que o levam, inclusive, a permanentes impulsos reformistas - ou de modernização.

${ }^{68}$ CAMARGO, 2019. 
Assim, o antagonismo reformismo-imobilismo se revela através de cisões internas, regionais e nacionais, que impõem complicados arranjos e se traduzem em crises frequentes. E é nessa sucessão de crises de desfecho institucionalmente incerto que se tece a história política brasileira deste momento.

Assim, é possível dizer que a modernização não foi capitaneada por um núcleo de elites renovadoras e dinâmicas, situado na periferia do sistema de poder, mas por uma oligarquia "dissidente" 69 , uma geração de políticos mais jovens do que os que dominavam a República Velha. Modernização esta forçada por um movimento de massa que já indicava a importância da população urbana e de suas reivindicações políticas. Este modelo corresponderia à "modernização conservadora", já apontando por esta tese algo próximo do padrão de transição assumido pela Alemanha, cujo resultado estaria expresso na excessiva concentração do poder político e que se traduziu na construção de uma estrutura corporativista de representação de interesses.

De um modo geral, podemos afirmar que as vinculações agrárias nos momentos de 1930, com reflexos ao longo das décadas seguintes, tenderam a se diversificar ao longo do ciclo quando muitos proprietários rurais penetram também na indústria. Ocorre também, em sentido inverso, que o segmento se consolida no interior da elite política.

Este é o caso dos capitalistas industriais nacionais - e regionais como o capixaba - que inicialmente permanecem nos intervalos do poder e que se fortalecem, à medida que o sistema industrial se expandia. A este respeito, Renato Perissinoto (2014) chama atenção para o contexto das elites modernizantes, que se refere à presença, numa dada sociedade, de elites disposta a industrializar e modernizar o país, tomando "decisões desenvolvimentistas" e as implementando conforme um plano. Essas elites modernizantes se dedicam à construção de um Estado que oriente suas ações econômicas por um plan rationality ${ }^{70}$ - ou planejamento racional -, em oposição à racionalidade de mercado e à racionalidade estritamente ideológica.

A característica específica deste planejamento racional consiste num tipo de intervenção estatal pautada pela produção de determinados resultados, considerando a ideia de que "eficácia" predomina sobre a de "eficiência". Mas

${ }^{69}$ Idem, 2019, p. 20

${ }^{70}$ JOHNSON, 1982, pp. 17-21. 
estabelecimento de elites modernizantes não é condição suficiente para a existência desse Estado, mas sim necessária, sem a qual não haveria as decisões desenvolvimentistas.

\begin{abstract}
"Não basta, portanto, que todas as características institucionais e contextuais identificadas acima estejam presentes se uma sociedade não conta com um grupo social disposto a assumir politicamente a tarefa de controlar o Estado, construir suas capacidades institucionais e promover o desenvolvimento como um "projeto" político, cuja evolução dependerá muito das características desse grupo." (Idem, 2014, p. 63)
\end{abstract}

As elites modernizadoras são o sustentáculo que produz instituições para que os Estados capitalistas alcancem metas desenvolvimentistas. As instituições do Estado, contudo, serão importantes porque reproduzirão os agentes que irão operálas, isto é, a burocracia técnica - que também é política. Estas instituições estatais irão produzir os agentes que, por sua vez, irão reproduzi-las por meio de suas práticas. Uma elite burocrática pequena, integrada, ainda que não monolítica, próxima do Poder Executivo, recrutada essencialmente nas estruturas burocráticas do Estado e caracterizada pelo predomínio de uma burocracia econômica.

Por fim, a produção de uma burocracia dotada de poder para construir um “consenso político" também é uma das características destas elites. É possível dizer que o desenvolvimento econômico se torna então fenômeno prioritariamente político e a sua ocorrência depende muito da capacidade política de tal elite modernizante em forjar esse tipo de coalizão com outras elites exteriores ao Estado. Cumprindo o papel de agente de ligação $o^{71}$, essencial para qualquer projeto desenvolvimentista e cumprindo o papel de elites estratégicas, proposta por Adriano Condato (2009):

"A noção de "elite estratégica" (ou melhor: "elites estratégicas", já que há várias) foi proposta por Suzanne Keller há um bom tempo para contrapor-se à imagem de uma classe dominante politicamente unificada ("ruling class") e socialmente homogênea. Apesar do pressuposto normativo que orienta sua empreitada contra o elitismo clássico (no caso, o pluralismo), há três ideias na base desse conceito que são úteis para descrever e explicar o meu problema: $i$ ) nas "sociedades industriais" (i.e., naquelas sociedades que conhecem um intenso processo de transformação capitalista), a reprodução da ordem social não cabe apenas a um único grupo social que controla, ao mesmo tempo, os recursos políticos e os recursos econômicos; ii) no recrutamento para o universo da elite política, atributos adquiridos (conhecimento técnico, experiência etc.) contam muito mais que atributos herdados ou background de classe, de modo que a origem social do grupo no poder é muito mais heterogênea do que numa ordem tradicional onde "riqueza" desempenha um papel essencial; e iii) uma

\footnotetext{
${ }^{71}$ HIRSCHMANN, 1964.
} 
elite estratégica pode tornar-se, em função das tarefas específicas que deve desempenhar, cada vez mais autônoma, seja em termos organizacionais, seja em termos profissionais, ou mesmo ideológicos (em relação ao grupo de origem)."

Se de um lado esta política e está burocracia incrustada no Estado desenvolvimentista absorvem o setor empresarial, também se verifica a tendência inversa: a atividade política pode constituir o trampolim de um capital inicial que permite a incorporação de quadros políticos à indústria reforçando a organicidade da estrutura social.

As elites capixabas tiveram, ao longo do tempo de construção das capacidades do Estado, - como veremos com mais profundidade no decorrer desta pesquisa - que responder ao desafio de definir quais os limites aceitáveis de seu projeto nacional em âmbito local. Podemos incluir nesse caso a controvérsia sobre a vocação industrial ou agrícola, que só se acomoda no governo Juscelino Kubitschek, e que terá repercussões também no Espírito Santo.

Mas, no período de 1946 a 1964, aos poucos concentrou-se o poder no processo decisório, para permitir formas mais simplificadas e informais de condução dos negócios públicos. A modernização a partir daí se coloca com a participação subalterna do setor industrial privado, mas que logo em seguida se infiltra no aparelho de Estado para colher os frutos do transcurso da industrialização estatal. 


\section{CAPÍTULO 3 - A CARACTERIZAÇÃO DE UM "ESTADO-ELÉTRICO" ENTRE 1946 E 1964}

\subsection{O entrelaçamento entre a administração estatal e a infraestrutura de energia elétrica no estado do Espírito Santo.}

Entre 1946 e 1964, a modernização brasileira alicerçada em uma industrialização estatal, como vimos até aqui, entrelaça seu sucesso ao desenvolvimento da infraestrutura elétrica levando a criação do que caracterizaremos de Estado Elétrico. Assim neste capítulo, veremos como as particularidades deste processo em âmbito capixaba, sobretudo a partir da ação de elites e grupos políticos regionais que buscaram o controle dos processos de mudança econômica, moldaram a construção de um sistema elétrico.

É possível dizer que enredo da modernização capixaba - acompanhando o movimento do país - tomou velocidade a partir de 1945. Do ponto de vista político, esta modernização esteve diretamente relacionada à redemocratização do país que inaugurou uma nova fase na conjuntura de transformação do Estado brasileiro, e onde a estrutura política foi reaberta a uma maior participação das classes sociais presentes na formação social brasileira, inclusive sob o ponto de vista regional.

Por este caminho, a Constituição Federal de 1946 redefiniu as formas de articulação existente entre a instância do político e o campo das práticas de classe ${ }^{72}$. Efetivamente, esta constituição reintroduziu o regime democrático tanto como padrão definidor da estrutura do político, quanto das relações entre as estruturas. A compreensão desse conjunto de relações políticas remete à análise dos elementos constitutivos do aparato político-institucional que se formou em âmbito federativo.

Ao longo destes 18 anos - 1946 a 1964 - em que o regime democrático esteve presente na formação social brasileira, quase todos os partidos que se consolidaram no cenário nacional marcaram presença no espaço político-partidário dos Estados federados, inclusive no estado do Espírito Santo.

\footnotetext{
${ }^{72}$ CPDOC (FGV). Entre dois governos: 1945-1950 e a constituição de 1946. Rio de Janeiro, 25 nov. 2020. Disponível em: https://cpdoc.fgv.br/producao/dossies/AEraVargas2/artigos/DoisGovernos/Constituicao1946
} 
Podemos dizer que as transformações que se processaram no Brasil modificaram a face política capixaba em duplo sentido. Por um lado, ampliaram a composição das forças políticas pré-existentes e permitiram que as facções divergentes ou rivais entre si ocupassem espaços partidários distintos no sistema em formação. Por outro, criaram condições para que as classes sociais que estavam no seio da produção rural e urbana emergissem no cenário da representação política regional.

A divisão das forças sociais e políticas podia ser entendida assim: (1) as que estavam relacionadas às elites agrofundiárias, que conseguiram conquistar espaço na direção política do aparelho estatal com os movimentos de 1930 e ampliaram esse espaço de poder regional, no Espírito Santo. (2) As forças constituídas no seio da pequena produção rural e dos núcleos urbanos do interior do estado, que representavam a grande massa populacional da época - inclusive, grande parte desta população imigrante europeia. (3) E por último, as classes populares urbanas dos principais centros urbanos Vitória e Cachoeiro de Itapemirim, além de Colatina $^{73}$.

Mas, efetivamente, na estratégia estadual, esteve presente de forma marcante os laços de afinidades e vinculações pré-existentes entre as lideranças políticas do Espírito Santo com aquelas constituídas a nível nacional.

Dois caminhos neste sentido se destacam: o primeiro trilhado por um mesmo conjunto de forças sociais que se abrigaram em partidos de nível nacional, como Carlos Lindenberg e Jones dos Santos Neves no PSD, e um segundo caminho, de lideranças historicamente opostas entre si, a nível estadual, que integraram um mesmo partido, como Attílio Vivácqua e Asdrubal Soares, que também foram para o PSD, mesmo tendo Lindenberg e Neves como seus principais rivais políticos ${ }^{74}$.

\footnotetext{
${ }^{73}$ Cidade próxima à divisa com Minas Gerais.

${ }^{74}$ Importante trazer a análise de Silva (1986), em que, segundo ela, esta dinâmica "refere-se ao fato de os partidos precisarem se constituir enquanto organizações nacionais, o que vai ensejar a necessidade de fundar diretórios em todos os Estados da Federação, por uma parte; e, a existência, no Espírito Santo, de um grupo heterogêneo de lideranças políticas, constituído por, pelo menos, três categorias distintas: a) as historicamente rivais no plano estadual como: Fernando de Abreu, Carlos Lindenberg, Henrique (tais Novais, versus Attílio Vivácqua, Ailton Tovar, Eleosippo Cunha, Geraldo Vianna, etc.); b) as pertencentes a um mesmo conjunto de forças sociais, mas que, no plano político, se dividem para garantir sua permanência no controle do Aparelho Regional de Estado. (Como por exemplo: Carlos Lindenberg (PSD) e seu irmão Fernando Lindenberg (UDN), Manoel Silvino Monjardim (PSD) e Adelpho Poli Monjardim (PTB); Jones dos Santos Neves (PSD) e Guilherme dos Santos Neves (PTB), etc.). c) as novas lideranças que surgiram em função da maior diferenciação social, e da ocupação de novos espaços territoriais do Espírito Santo - norte do Estado.
} 
Toda essa conjuntura, se torna mais visível na primeira eleição pós Estado Novo, onde se consuma a vitória do candidato da coligação PSD/UDN, Carlos Lindenberg (1947 a 1950) ${ }^{75}$, que nutria forte relação inter-coroneis.

Em termos comparativos com a região sudeste, onde a prática populista passava a ser norteadora da vida política no Espírito Santo, as práticas coronelistas serão requentadas, constituindo o domínio político da época, apoiadas sobre a máquina partidária nacional.

Contudo, diferente do campo político, os últimos anos da década de 1940 consolidaram as mudanças estruturais na economia e, principalmente, no papel do Estado. Culminando, na passagem de uma economia baseada na exportação de produtos agrícolas para uma economia industrial direcionada ao mercado interno e urbano, tendo o aparato estatal como elemento indutor deste movimento.

Este momento impulsiona novas relações entre o Estado e os atores políticos e econômicos, constituindo uma condição determinante para a consolidação do capitalismo no país, e sobretudo, no Espírito Santo. Conjuntura esta que tem como um dos delimitadores uma contundente ação estatal no setor de eletricidade, com a intensa participação das elites políticas em prol do seu desenvolvimento, o qual chamaremos de Estado-elétrico.

Neste ínterim, é Carlos Lindenberg que, mesmo fortemente ligado às forças políticas e econômicas do latifúndio, tentou fomentar o crescimento industrial através da geração de eletricidade, como uma das prioridades de sua gestão. O que levou ao planejamento de novas usinas como a de Jucu II, negociada em parceria, em forma de empréstimo, com a CCBFE.

É importante dizer que estes projetos elétricos também estavam relacionados à introdução de técnicas de planejamento econômico tendo em vista o avanço de uma industrialização de base a nível nacional, a partir do complexo de minério e siderúrgico da Companhia Vale do Rio Doce, além de operações portuárias, em sua maioria, com forte investimento do governo federal.

Entre as primeiras pode-se destacar: Eurico Rezende (UDN), Fernando Duarte Rabelo (PDC), José Cupertino de Almeida (PSP) - representantes das classes médias urbanas -; Saturnino Rangel Mauro (PTB), Benjamim Campos (PCB) - representantes das classes populares urbanas - e, entre as segundas: Wilson Cunha (PR), Moacyr Brotas (UDN)i Alberto Ceolim (PRP), etc. (SILVA, 1986, p. 310)".

75 Segundo, Alvarenga (2017), os membros e apoiadores do PSD faziam parte de uma elite latifundiária, sobretudo as que dominavam a produção do café. Essa característica fazia com que a influência do partido incidisse tanto nas áreas urbanas quanto nas rurais. 
Entretanto, a eletricidade ainda continuava escassa nas cidades capixabas, sobretudo em vários bairros de Vitória que estavam em franca expansão. Importante observar que os dados populacionais do período entre 1920 e 1950 reforçam a percepção de um crescimento populacional do Espírito Santo, sobretudo, a partir da capital e de sua região metropolitana - Grande Vitória -, que fica no entorno de $117 \%$ entre 1920 e 1950 e em $82 \%$ entre 1950 e 1960. Enquanto a população rural, mesmo que ainda predominante, passa de $71,8 \%$ em 1960 para $54 \%$ em $1970^{76}$.

O fornecimento de energia também não conseguia ter a estabilidade exigida pelas indústrias e pelos comércios, problemática tratada pela CCBFE com soluções paliativas. Em entrevista, Christiano Dias Lopes ${ }^{77}$ aponta sua visão sobre o problema da expansão da energia no Espírito Santo durante a concessão a CCBFE naquele momento:

“[...] a Companhia Central Brasileira de Energia Elétrica dizia: não podemos investir em energia elétrica porque o Espírito Santo não tinha consumo; e o Espírito Santo não tinha consumo porque não se desenvolvia; não se desenvolvia porque não tinha Energia Elétrica. E ficava naquele negócio de uma empurra para lá outro empurra para cá." 78

A disputa política das eleições de 1950 que elegeu Jones dos Santos Neves (1951 a 1955) - agora de forma democrática ${ }^{79}$ - se colocava no olho da furação em uma crescente campanha de encampação da CCBFE e pela melhoria da infraestrutura de eletricidade. A campanha, com forte viés nacionalista, se dava através de um movimento suprapartidário liderado pelo tenente-coronel do exército José Patente Frota ${ }^{80}$ e por integrantes da linha de frente do PSD. Mas que agregava,

\footnotetext{
${ }^{76}$ BITTENCOURT, 1984.

${ }^{77}$ Que viria a ser governador entre 1967 e 1971.

${ }^{78}$ Entrevista concedia a Luiz Claudio M. Ribeiro. Vitoria: nov. 2002, p.6.

${ }^{79}$ Jones dos Santos Neves havia sido interventor de Getúlio Vargas em 1943.

${ }^{80}$ José Patente Frota. Importante personagem político (mesmo quando ainda militar) capixaba com articulação nacional, entre a década de 1950 e todo o período do regime militar. Presente na sessão verbetes do CPDOC/FGV: Em 1951 foi nomeado chefe de polícia do estado do Espírito Santo no governo de Jones dos Santos Neves. Bacharelou-se em ciências jurídicas e sociais pela Faculdade de Direito do Espírito Santo em 1952, deixando a chefia da polícia capixaba em 1954. Promovido a tenente-coronel em 1956, passou para a reserva, alcançando o generalato no final da década de 1950, quando iniciou sua carreira política. No pleito de outubro de 1958 elegeu-se deputado estadual no Espírito Santo na legenda do Partido Social Democrático (PSD), ocupando a cadeira em fevereiro do ano seguinte. De 1961 a 1962 foi líder da bancada de seu partido na Assembleia Legislativa. Em outubro de 1962 reelegeu-se na mesma legenda. Com a extinção dos partidos políticos pelo Ato Institucional $n^{\circ} 2(27 / 10 / 1965)$ e a posterior instauração do bipartidarismo, filiou-se à Aliança Renovadora Nacional (Arena), partido de sustentação ao regime militar instalado no país em abril de 1964. m novembro de 1966 elegeu-se deputado federal pelo Espírito Santo na legenda da Arena. Deixando a Assembleia em janeiro de 1967, tomou assento na Câmara em fevereiro seguinte. No
} 
igualmente, membros do Partido Comunista Brasileiro e de diversos partidos com viés nacionalista.

Dentro deste panorama, o governo de Jones dos Santos Neves vai se produzir a partir da materialização de um projeto de uma modernização para o Espírito Santo, produzindo as condições para a sua implementação a partir da ideia de necessidade de uma infraestrutura adequada, sendo a energia elétrica uma das prioridades.

Todavia, como problemática fundamental, se colocava a dissociação entre a instância do agente político (Estado) e as demais instâncias (econômica e sociais) em um contexto de uma população predominantemente rural e uma economia agro fundiária. O que leva em muitos momentos Neves, mesmo tendo como plataforma política a época de sua eleição uma aliança com a oligarquia agrofundiária, a atender apenas as necessidades básicas deste grupo em detrimento da continuidade de um projeto de governo ${ }^{81}$, que desse conta da construção de um aparato estatal para a modernização.

A aprovação do primeiro Plano Estadual de Eletrificação, lei nº 527 de 1951, é uma das manifestações deste cenário. Teve uma intensa participação das elites capixabas, tendo como pilares a construção de hidroelétricas e a criação de uma empresa estadual de energia que, nas palavras de Jones dos Santos Neves, seria “ $o$ fundamento inicial da nossa redenção econômica".

O Plano Estadual de Eletrificação foi resultado de articulação concentrada do PSD capixaba na esfera nacional. Foram as articulações entre Neves, Getúlio Vargas e Oswaldo Aranha que fizeram com que o recém-criado BNDE (Banco Nacional do Desenvolvimento Econômico) assumisse o pagamento integral da construção da hidrelétrica de Rio Bonito - uma das principais obras do Plano Estadual - e de linhas de transmissão. Em contrapartida, o Governo do estado teria

pleito de novembro de 1970 reelegeu-se na mesma legenda. Durante essa legislatura foi presidente da Comissão de Segurança Nacional e suplente das comissões de Constituição e Justiça, de Fiscalização Financeira e Tomada de Contas, de Minas e Energia e de Transportes, Comunicações e Obras Públicas. No pleito de novembro de 1974 voltou a reeleger-se deputado federal pelo Espírito Santo na legenda da Arena. Foi vice-líder do governo e de seu partido da Câmara, voltando a integrar a Comissão de Segurança Nacional e, como suplente, a Comissão de Constituição e Justiça. Deixou a Câmara dos Deputados em janeiro de 1979. No governo de Eurico Resende, iniciado no mesmo ano, Parente Frota foi nomeado secretário de Segurança Pública. CPDOC (FGV). Dicionário Histórico-Biográfico Brasileiro On-line: Jones dos Santos Neves. Rio de Janeiro, 29 dez. 2020. Disponível em: http:// http://www.fgv.br/cpdoc/acervo/dicionarios/verbete-biografico/jones-dossantos-neves.

${ }^{81}$ SILVA, 1986, p. 436. 
por obrigação contratual organizar a formação da Espírito Santo Centrais Elétricas S/A.

Ainda se utilizando de ligações com a área técnica de planejamento econômico, e de suas relações partidárias e de sua amizade com Getúlio Vargas, Jones dos Santos Neves e seu grupo político estabeleceram projetos para organização da administração econômica do estado, reunindo os instrumentos de planejamento já utilizados na esfera federal. Neves tinha plena convicção da necessidade de obras de infraestrutura econômica, dada a carência em que todo o território capixaba se encontrava.

Assim, é possível dizer que o papel da energia elétrica, momento da modernização capixaba, segue o caminho citado por Alexandre Saes $(2008)^{82}$ :

\begin{abstract}
"conjugado com a emergência do processo de industrialização e urbanização, as transformações no sistema de eletricidade eram parte fundamental na formação do capitalismo brasileiro. As decisões e os projetos políticos para o desenvolvimento do setor de energia elétrica representavam, no limite, as formas como as classes dominantes do país pensavam no grau de subordinação ao capital estrangeiro e a intensidade da modernização".
\end{abstract}

Isso fica bem demarcado quando Jones dos Santos Neves analisa os propósitos da política elétrica e sua relação com os eixos de modernização capixaba, quando diz: “(...) a eletrificação do Estado obedece ao proposito estabelecido nas diretrizes do atual governo de preferência as centrais que mais se aproximem dos eixos de gravidade econômica." E complementa no mesmo discurso:

\footnotetext{
“(...) situação estratégica de seu porto de mar (...) tendo como tributarias as regiões de todo o 'hinterland' mineiro, o crescente caudal de minério de ferro que desce das vertentes do Itabira em busca do oceano para se encontrar com o carvão importado, tudo isso faz deste litoral um centro monopolizador de futuras industriais ${ }^{83}$ ".
}

Investimentos em energia elétrica foram considerados fundamentais no Espírito Santo, bem como o aparelhamento do estado enquanto ente capaz de planejar e prover o sistema de suporte institucional, fiscal e financeiro. Neste ponto, é possível caracterizarmos a ideia de Estado-elétrico dentro de uma categoria de

\footnotetext{
${ }^{82}$ SAES, 2008.

${ }^{83}$ Espírito Santo (Estado). Governador 1952, 1953, 1954. Vitória: Impressa Oficial apud. Silvia, op. cit., p.261, 262, nota 29.
} 
dominação racional legal, na qual Max Weber ${ }^{84}$ observa como a forma de dominação típica do Estado moderno. Estado este que se torna lugar da existência de normas legais, pela existência de um conjunto administrativo burocrático e onde se colocam pressupostos importantes para mitigar os potenciais conflitos que possam existir entre a atividade econômica, a atividade política e a administração pública, no processo de implantação de uma infraestrutura para a eletrificação. Como caminho único.

Tal conjuntura deu a Jones do Santos Neves - como a grande parte das elites políticas capixabas igualmente - o argumento básico para propor ações intervencionistas estatais massivas no Espírito Santo. Neste sentido, se produz o Plano de Valorização Econômica do estado. Este plano expressou o delineamento das prioridades econômicas da sua gestão no decurso da modernização estatal, o que exigiu o suporte tecnocrático para sua execução, levando a busca por técnicos no Espírito Santo e, sobretudo, nos estados vizinhos para tal fim. A ideia era que os locais da administração pública considerados centrais para as tarefas do projeto de Neves, precisavam de uma direção capaz de imprimir dinamismo.

Paralelamente ao Plano de Valorização Econômica, foi criada a Secretaria de Viação e Obras Públicas, promovendo, para isso, o desmembramento da Secretaria de Agricultura, Viação e Obras Públicas. Dada a importância que foi atribuída a Secretaria para a execução da política econômica, ela foi superequipada tecnicamente, e absorveu a maior parte dos recursos financeiros do Estado, em média $42,7 \%^{85}$.

$\mathrm{O}$ reforço dessa tendência vem com o aterro de mangues, enseadas, desmonte de morros e consequente construção de novas avenidas e o porto de Vitória. Também se constitui o aeroporto, prédios comerciais à beira-mar e loteamentos. Em 1950, o Plano de Valorização Econômica do Estado concentrava $39 \%$ da capacidade de investimento estatal em cinco anos, em que, das 4 áreas prioritárias, $23 \%$ do seu valor total de investimento era destinado ao setor de energia elétrica ${ }^{86}$.

\footnotetext{
${ }^{84}$ WEBER, 1981.

${ }^{85}$ GONÇALVES, 2010 p. 67.

${ }^{86}$ ESPÍRITO SANTO [Estado]. Plano de valorização econômica do Espírito Santo. Mensagem enviada pelo Sr. Governador a Assembleia Legislativa em 22 de maio de 1951. IJSN, Vitória, ES: 1951.
} 
O plano incluía também a contratação da empresa alemã AEG Allgemeine Elektrizitats-Gesellschaft pelo Governo do estado, para a análise das bacias hidrográficas e, em especial, para análise do potencial de uso hidrelétrico da bacia do rio Santa Maria. A definição do aproveitamento dessa bacia levou em conta a consequente redução de prazos e custos das obras de linhas de transmissão. Além disso, a eleição deste aproveitamento como ponto de partida para o aproveitamento hidrelétrico no estado obedece ao propósito estabelecido pelas diretrizes de aproximação dos centros de gravidade econômica, especialmente a região central, onde fica a capital Vitória, e a centro-sul, onde fica Cachoeiro de Itapemirim.

Outra questão também pertinente é que o Plano de Eletrificação Estadual se torna peça ajustada ao surgimento de um setor público de eletricidade nacional. Esta sincronia, que unia o projeto estadual à construção de uma racionalidade técnica do segundo governo varguista (1951-1954), pode ser vista a partir das leis criadas pelo governo Neves, que eram cópias ajustadas dos projetos aprovados no congresso nacional do primeiro período varguista ${ }^{87}$.

O intuito desta proximidade por parte do governo estadual era, para além de uma associação política com o governo federal, ajustar as estruturas jurídicas das concessões de prestação de serviços públicos com os financiamentos captados através do governo federal ${ }^{88}$. Contudo, mesmo que com grande capacidade de articulação política estadual e federal, não seria no governo Jones dos Santos Neves que se construiria uma empresa pública de grande porte para o setor elétrico do estado, nem se inaugurariam boa parte das obras de geração de energia.

A respeito da ESCELSA, ela despontaria pela primeira vez apenas em $1956^{89}$, no governo sucessor de Neves, Francisco Lacerda de Aguiar (1955 e 1959) ${ }^{90}$, absorvendo pequenas empresas de geração, transmissão e distribuição e suprindo

\footnotetext{
${ }^{87}$ RIBEIRO, 2013.

${ }^{88}$ Ver mais em Lei federal $n^{\circ} 1.628$ de junho de 1952 . Art. $8^{\circ} ; \mathrm{n}^{\circ} 1807$, de 7 de janeiro de 1953 sobre empréstimos para serviços públicos. Sendo a Lei estadual $n^{\circ} 755$, de 07 de dezembro de 1953 a mais importante delas, que criava o sistema elétrico estadual e que teve como resultado mais concreto a constituição da Espírito Santo Centrais Elétricas S/A, resultado de acordo específico com o governo do estado do Espírito Santo.

${ }^{89}$ A criação da ESCELSA só se deu a partir da aprovação da Lei 1.088, de 30 de agosto de 1956 que instituiu a taxa de juros de $9 \%$ para o empréstimo a ser feito junto ao BNDE, além de criar o Fundo de Eletrificação a ser composto pela parcela que cabia ao estado do Imposto Único de Energia Elétrica (Lei federal $n^{\circ} 2308$ de 1954.).

${ }^{90}$ Francisco Lacerda de Aguiar. Em outubro de 1950, elegeu-se deputado federal pelo Espírito Santo na legenda do PSD. Ocupou sua cadeira na Câmara dos Deputados de março de 1951 a janeiro de 1955. Mesmo tendo se desligado do PSD, seu prestígio crescera o suficiente para lhe permitir
} 
as deficiências de abastecimento da zona de concessão da Companhia Central Brasileira de Força Elétrica (CCBFE).

É importante notar o conjunto de forças que se aglutinaria em torno da Assembleia de constituição da Espírito Santo Centrais Elétricas S/A. Além do governador, estavam Lysandro Ceciliano de Oliveiras, Azeredo de Souza Werneck, Oswald C. Guimarães ${ }^{91}$, Orlando Antenor Guimarães ${ }^{92}$, Álvaro Sarlo ${ }^{93}$, Asdrúbal Soares ${ }^{94}$, José Ribeiro Martins, Alcides Guimarães, Alcides Vianna, Hildewald Guimarães, Afonso Sarlo, Antenor Guimarães ${ }^{95}$, Jose Ferrari Valls, Alberto de Oliveira, Oscar Rodrigues de Oliveira, José Fortunato Ribeiro ${ }^{96}$, Manoel Moreira Camargo, Eurico Resende ${ }^{97}$, Fernando Costa, José Rodrigues Oliveira, Emílio

candidatar-se em 1954 ao governo do Espírito Santo. Elegeu-se governador em 3 de outubro na legenda da Coligação Democrática, constituída pelo Partido Trabalhista Brasileiro (PTB), o Partido Republicano (PR), o Partido de Representação Popular (PRP) e o Partido Social Progressista (PSP), derrotando Eurico Sales, da Aliança Interpartidária, composta pelo PSD e a União Democrática Nacional (UDN). CPDOC (FGV). Dicionário Histórico-Biográfico Brasileiro On-line: Francisco Lacerda de Aguiar. Rio de Janeiro, 30 nov. 2020. Disponível em: http://www.fgv.br/cpdoc/acervo/dicionarios/verbete-biografico/aguiar-francisco-lacerda-de

${ }^{91}$ Prefeito de Vitória (1958 a 1959).

92 Empresário Local.

${ }^{93}$ Prefeito de Vitória (1935 a 1936).

${ }^{94}$ Asdrúbal Soares, Prefeito de Vitória (1930 a 1933). Elegeu-se primeiro suplente de deputado à Assembleia Nacional Constituinte pelo Espírito Santo em 1933, no Partido Social Democrático (PSD). Ainda em 1933, foi secretário de Agricultura, Viação e Obras Públicas de seu estado, na gestão do interventor João Punaro Bley (1930-1935). Após a promulgação da Constituição, foi eleito deputado federal pelo PSD. Ainda em 1934, foi lançado candidato ao governo capixaba na legenda das Oposições Coligadas, formadas pelo Partido da Lavoura e o Partido Proletário. Assumiu sua cadeira na Câmara dos Deputados em julho de 1935 e exerceu o mandato até 10 de novembro de 1937, quando o advento do Estado Novo suprimiu os órgãos legislativos do país. Em seguida, passou a dedicar-se à sua carreira profissional, tornando-se diretor-proprietário de uma companhia de serviços de engenharia, a Empresa Brasileira de Engenharia e Comércio (EBEC). Com o fim do Estado Novo e a redemocratização do país, em dezembro de 1945 elegeu-se deputado à Assembleia Nacional Constituinte pelo PSD. Em janeiro de 1948 votou contra a cassação dos mandatos dos parlamentares comunistas. Deixou a Câmara ao final da legislatura, em janeiro de 1951. Em agosto de 1962 foi eleito governador interino pela Assembleia Legislativa do Espírito Santo, substituindo Hélcio Pinheiro Cordeiro, também governador interino. Assumiu as funções logo em seguida e em janeiro de 1963 entregou o cargo a Francisco Lacerda de Aguiar, eleito em outubro de 1962. Além disso, dirigiu os jornais O Estado e A Tribuna, em Vitória, e primeiro presidente da Espírito Santo Centrais Elétricas S.A. (Escelsa). CPDOC (FGV). Dicionário Histórico-Biográfico Brasileiro Online: Asdrúbal Martins Soares. Rio de Janeiro, 30 nov. 2020. Disponível em: http:// http://www.fgv.br/cpdoc/acervo/dicionarios/verbete-biografico/soares-asdrubal-martins

${ }^{95}$ Empresário, dono da Antenor Guimarães \& Cia. Ltda, empresa que prestava serviços de transporte e infraestrutura portuária, logística marinha, além de grande de empresas no ramo da construção civil e de serviços para o governo do estado.

${ }^{96}$ Desembargador.

${ }^{97}$ Eurico Resende. Após o Estado Novo e o início do processo de redemocratização, filiou-se à União Democrática Nacional (UDN), partido político criado em 1944. Elegeu-se para a Assembleia Legislativa do Espírito Santo em 1950, 1954 e 1958, sempre pela UDN. Em 1962, elegeu-se senador pelo Espírito Santo, apoiado por uma coligação constituída pela UDN e pelos partidos Democrata Cristão (PDC), Trabalhista Brasileiro (PTB), Social Progressista (PSP) e de Representação Popular (PRP). Deixou a Assembleia Legislativa em janeiro de 1963, ao final da legislatura, e no mês 
Roberto Zanotti, José Franklin dos Santos, Eurico Fernandes, Manoel Bezerra Nunes, Aylton Tovar, Acyr Monteiro, Joaquim Leite de Almeida, Antônio Pereira Lima e Tasso da Silveira Pessoa. ${ }^{98}$

E na edição do jornal A Tribuna do dia da constituição da empresa, eram expostas as razões de sua função:

\begin{abstract}
"promover o aproveitamento das fontes de energia elétrica existentes no Estado; planejar, construir e operar sistema de produção, transformação, transmissão e distribuição de energia elétrica, sob suas diversas modalidades; explorar, mediante concessão, o comercio de energia elétrica; adquirir, por qualquer título, ou arrendar usinas geradoras de eletricidade, linhas de transmissão e redes distribuidoras de energia elétrica; interessar-se em empreendimentos ou empresas que tenham por objetivos a indústria de energia elétrica e promover quando possível ou necessário, a articulação d'agua das usinas geradoras com as que se puderem destinar à regulação dos rios e seu aproveitamento em obras de irrigação $(06 / 09 / 1956$, p. 05)".
\end{abstract}

$\mathrm{Na}$ primeira assembleia da empresa, foi eleito um dos presentes na cerimônia de criação, Asdrúbal Soares ${ }^{99}$, como presidente. É relevante dizer que o primeiro presidente da Escelsa era habituado ao executivo público, pertencente ao grupo vitorioso no movimento de 1930, assim como Jones dos Santos Neves e Carlos Lindenberg. Chegou ao poder com a nomeação do primeiro interventor de Getúlio Vargas no Espírito Santo João Plunaro Bley, que, por sua vez, o nomeou prefeito da capital.

A indicação de Soares para presidente da Escelsa foi de substancial importância para o futuro da empresa. Como presidente do diretório estadual do

\footnotetext{
seguinte assumiu sua cadeira no Senado, onde exerceria a vice-liderança da UDN, logo desde março e até a extinção do partido, dois anos e meio depois. Participou, em seu estado, das articulações que resultaram no golpe de 1964 que depôs o presidente João Goulart (1961-1964). Com a extinção dos partidos políticos pelo Ato Institucional $\mathrm{n}^{\circ} .2(27 / 10 / 1965)$ e a posterior instauração do bipartidarismo, filiou-se à Aliança Renovadora Nacional (Arena), de orientação governista. Participou da redação final da nova Constituição promulgada em 24 de janeiro de 1967 e no ano seguinte tornou-se vice-líder do governo e, a partir de 1969, vice-líder da Arena no Senado. Em 1970 foi relator do decreto-lei do governo que o Congresso referendou, instituindo a censura prévia das publicações periódicas. No pleito de novembro de 1970, reelegeu-se senador pelo Espírito Santo na legenda da Arena, assumindo o mandato em fevereiro de 1971. Nessa legislatura, continuou vicelíder da Arena e do governo no Senado, tendo sido titular das comissões de Constituição e Justiça, do Distrito Federal e de Legislação Social, além de suplente da Comissão de Finanças. Resende foi escolhido em março de 1977 pelo presidente Ernesto Geisel (1974-1979) líder da maioria no Senado, substituindo o senador Petrônio Portela. Em setembro de 1978, elegeu-se, por via indireta, governador do Espírito Santo. Substituindo Élcio Álvares (1974-1979), tomou posse em março de 1979. Com a extinção do bipartidarismo em novembro de 1979 e a consequente reformulação partidária, filiou-se ao Partido Democrático Social (PDS). CPDOC (FGV). Dicionário HistóricoBiográfico Brasileiro On-line: Asdrúbal Martins Soares. Rio de Janeiro, 01 dez. 2020. Disponível em: http://www.fgv.br/cpdoc/acervo/dicionarios/verbete-biografico/eurico-vieira-de-resende

${ }^{98}$ Escritura Pública da Construção da Sociedade. O Diário. 29/11/1956, p. 4-5.

${ }^{99}$ Que viria a ser governador interino entre 1962 e 1963.
} 
Partido Social Progressista (PSP), fora um dos principais articuladores de uma coligação que unia PSP, PTB, PR, PRP e parte da UDN, e foi responsável por atrair Francisco Lacerda de Aguiar para o PTB, na eleição em que se tornaria governador.

O governo de Francisco Lacerda de Aguiar (ou Chiquinho) apresenta uma plataforma de continuidade com relação ao governo Neves. Mesmo que, em relação ao seu antecessor, existisse uma ainda mais profunda relação com setor agrárioexportador cafeeiro. Esta continuidade está fortemente relacionada a alguns fatores, como ao resultado do protagonismo do Estado no desenvolvimento econômico com a integração dos planos nacional e estadual, e ao início de um relativo consenso sobre a necessidade de industrialização por parte das forças políticas das várias regiões do estado.

Neste universo, a energia elétrica era vista para além de necessária, mas como essencial ao projeto de industrialização, modernização e aumento de produtividade na agricultura. Isso fica explícito em fala do Secretário de Fazenda do Espírito Santo no governo Chiquinho - como também era conhecido o governador Francisco Lacerda de Aguiar -, Kleber Guimarães, em 1957:

\begin{abstract}
“[...] Não é preciso tecer comentários, por certo, sobre o que representa a eletricidade no meio rural, dotando o homem do campo das condições de bem-estar que estimulam e o confortam, facilitando a criação da pequena indústria rural, de tanta significação, nem tampouco a expressão que tem as cidades a fartura de energia, propiciando a constituição de conjuntos industriais que irão fortalecer nossa economia." 100
\end{abstract}

\title{
3.2 A empresa pública de energia e o Estado como desenvolvimento entre 1946
} e 1964.

A ascensão de uma elite técnica em âmbito estatal relaciona-se à ideia de uma modernização pautada por um positivismo político e racionalidade administrativa, que vai se apresentar, igualmente, como a acentuação de um projeto de expansão do modo de produção capitalista, em duas dimensões: um de base tecnocrática e outra de caráter político-ideológico. E é sob o governo Eurico Gaspar Dutra (1946 a 1951) que, mesmo enquanto se baixavam as pretensões do caminho de aceleração e modernização industrial, se acentuava os impulsos para uma ação mais centralizada, coordenada e tecnocrática do Estado na economia ${ }^{101}$.

\footnotetext{
${ }^{100}$ ESPÍRITO SANTO. Assembleia Legislativa, 1957.

${ }^{101}$ DRAIBE, 1985, p. 85.
} 
O Plano Salte, como principal engajamento desenvolvimentista deste governo, compõe uma imagem interessante para analisar o período. O Plano envolveu a intensificação da racionalização em prol do desenvolvimento econômico brasileiro. Constituiu-se por programas coordenados e sistematizados de empreendimento e obras públicas, tendo como um dos principais avanços o uso do ponto de vista técnico, estatístico e o planejamento, como pilares.

Mas a respeito do setor de energia elétrica da época, a importância dada refere-se à tentativa de combate à perspectiva de escassez do fornecimento de eletricidade, que se abateu sobre o país durante a década de 1940. Esta crise atingia em cheio São Paulo, centro industrial do país, desembocando em um racionamento que se acentuou no ano de 1950.

É só no início do segundo governo Getúlio Vargas (1951 - 1954) que a energia volta a ocupar papel de maior destaque nas principais linhas de planejamento do governo federal. O que fica expresso em mensagem de Vargas ao congresso nacional em 1951:

\begin{abstract}
"Para que a eletricidade seja um elemento de progresso e permita o desenvolvimento industrial não é meramente necessário que seja barata, é indispensável, que seja sobretudo abundante. A oferta de energia deve preceder e estimular a demanda. A falta de reserva de capacidade e as crises elétricas são processos de asfixia econômica de consequências funestas. É indispensável, por isso, que o Poder público assuma a responsabilidade de construir sistemas elétricos, onde sua falta representa maiores deficiências." 102
\end{abstract}

O segundo governo varguista se propôs a avançar na montagem de infraestrutura para o desenvolvimento econômico, possibilitando a integração da indústria pesada de bens de capital e de insumos, aplicando capitais públicos nos empreendimentos considerados estratégicos, como a eletricidade.

Contudo, como aponta Eduardo Raposo (2011), Vargas chegou pela segunda vez acompanhado de uma grave crise que aprofundava as contradições e desigualdades da sociedade brasileira. E apesar de ter se manifestado em diferentes setores da sociedade e do Estado, esta crise tinha origem da mesma fonte e do mesmo hibridismo que já vinha caracterizando o desenvolvimento das instituições do país, divididas entre uma vocação política de natureza corporativa, preocupada

\footnotetext{
${ }^{102}$ Acessado em 17 de outubro de 2018. Disponível em: http://www.biblioteca.presidencia.gov.br/presidencia/ex-presidentes/Getúlio vargas/mensagens-aocongresso/mensagem-apresentada-na-abertura-da-sessao-legislativa-1951
} 
com a manutenção da clientela que apoiava seu projeto ${ }^{103}$ - com forte impacto na perspectiva regional -, e uma outra, de natureza mais universalista, mais difusa, fragmentada e pouco organizada politicamente.

Esta questão reverberou nas dinâmicas do setor elétrico, com o empenho constante para que, com o empreendimento público, não fossem ameaçados diretamente os interesses de grupos privados nacionais e de filiais estrangeiras. Dava-se preferência, mesmo com uma necessidade de investimentos em empreendimentos de interesse público, a contratos de fornecimento de equipamentos por exportadores estadunidenses, o que significava, com frequência, o financiamento ${ }^{104}$ direto das próprias empresas de energia multinacionais ${ }^{105}$. Na tabela 1, expõe-se o investimos e o acréscimo de energia entre 1952 e 1957 :

\begin{tabular}{|c|c|c|}
\hline \multicolumn{3}{|c|}{ Tabela 1 - investimos e o acréscimo de energia entre 1952 e 1957 } \\
\hline Empresas & Investimentos (Cr\$) & $\begin{array}{c}\text { Acréscimo de capacidade } \\
\text { geradora (MW) }\end{array}$ \\
\hline $\begin{array}{c}\text { Públicas (Chesf, CEEE-RS, } \\
\text { CEMIG-MG, USELPA (SP) }\end{array}$ & 4.240 & 331,2 \\
\hline Grupo Light & 696 & 160 \\
\hline Grupo Amforp & 2.179 & 170,6 \\
\hline $\begin{array}{c}\text { Independentes (Companhia } \\
\text { Nacional de Energia Elétrica e } \\
\text { Companhia Mato-grossense de } \\
\text { Eletricidade) }\end{array}$ & 114 & 21,1 \\
\hline TOTAL & $\mathbf{7 . 2 2 9}$ & $\mathbf{6 8 2 , 9}$ \\
\hline
\end{tabular}

Fonte: Relatório Geral da Comissão Mista Brasil - Estados Unidos para o Desenvolvimento Econômico.

De todo modo, o lobby das empresas de energia elétrica estrangeiras não impediu o financiamento de três empreendimentos públicos estaduais na geração de energia, a Companhia de Energia Elétrica Rio-Grandense (CEERG), Companhia Elétrica de Minas Gerais (CEMIG) e Usinas Elétricas do Paranapanema (USELPA), uma vez que os três empreendimentos atenderiam regiões à beira do colapso energético ${ }^{106}$.

E, mais importante, segundo Hildete Pereira de Melo Hermes de Araújo (1979, p.104), é a partir do diagnóstico da Assessoria Econômica do segundo governo varguista que se abre ainda mais o caminho para a intervenção maciça no

\footnotetext{
${ }^{103}$ Idem, 2011.

${ }^{104}$ Comumente realizados através de empréstimos internacionais.

105 Já que muitas delas também eram fornecedoras de equipamentos ou tinham algum tipo de relação com estas empresas. Como no caso da relação General Eletric e ANFORP.

106 BASTOS, 2007.
} 
setor de energia como solução do impasse de abastecimento industrial, bem como para o seu financiamento total. Na verdade, chega-se à conclusão de que só restava ao Estado brasileiro escolher entre duas ações: (1) ajudar as empresas privadas na captação de capital necessário, tendo ele que mobilizar os recursos em favor das empresas, ou (2) investir diretamente nele criando as empresas públicas para realizar os projetos. A opção pelo investimento direto coadunou com a política de criação de órgãos e empresas estatais voltadas para a execução de políticas públicas, que já estavam em curso.

Nesta direção, em 1953, o governo encaminha ao Congresso projeto de lei 3.204/53, que propõem a criação do Imposto Único sobre a Energia Elétrica (IUEE) e o Fundo Federal de Eletrificação (FFE) ${ }^{107}$, sendo este aprovado apenas em $31 / 08 / 1954{ }^{108}$

Além disso, na busca de financiamento, Vargas dá outro grande passo ao criar o Banco Nacional de Desenvolvimento Econômico - BNDE. O BNDE é especialmente importante para a história do setor elétrico, principalmente para custeio dos projetos dos setores elétricos regionais. E serão estes projetos regionais que terão grande impulso a partir daí.

Foram de Rio Grande do Sul, Minas Gerais e Paraná os primeiros planos estaduais de aproveitamento de eletricidade na década de 1950, inaugurando a prática da planificação no setor de energia elétrica no país ${ }^{109}$. Apesar de constituírem propostas distintas, compartilhavam importantes pontos em comum: disciplinavam o espaço de atuação do Estado e dos capitais privados nos setores de energia elétrica naqueles locais, e concebiam alguma integração com planos de desenvolvimento econômico regionais ${ }^{110}$.

A relevância da atuação das empresas estatais no setor elétrico está justamente na particularidade do setor no conjunto do planejamento brasileiro, que nasceu como fruto de experiências de empresas regionais, que contribuíram - ou

\footnotetext{
107 O Fundo contava, além de dotações orçamentárias, com $20 \%$ da arrecadação com despachos aduaneiros e com o Imposto Único sobre a Energia Elétrica (IUEE). Visava expressamente a constituição do capital das empresas públicas destinadas a investir no setor.

${ }^{108}$ Um pouco depois do suicídio de Vargas.

${ }^{109}$ Memória da eletricidade. A intervenção dos governos estaduais no setor de energia elétrica: os casos do Rio Grande do Sul, de Minas Gerais e do Paraná. Centro de memória da eletricidade. Rio de Janeiro, 2005.

${ }^{110}$ Veremos mais a respeito na seção "3.2.4 As empresas estaduais do setor elétrico como recorte do debate regional e federal"
} 
mesmo foram essenciais - na formulação do sistema elétrico nacional quando da criação da Eletrobrás em 1962.

É possível afirmar ainda que as diversidades e desigualdades regionais foram decisivas para a aplicação de distintas políticas energéticas nos estados. Neste sentido, o papel das companhias estaduais de energia elétrica, como instrumentos de uma política energética regional, representou a presença do poder empreendedor do Estado em sua forma local. Principalmente porque, a partir destas empresas, foram formulados os primeiros planos estaduais de aproveitamento energético nas décadas de 1940 e 1950, inaugurando a prática de planificação no setor elétrico. Até então, tanto o contexto normativo quanto de planejamento para o setor de energia elétrica, cabia as municipalidades que realizavam contratos de concessão às empresas que pretendessem gerar e fornecer energia elétrica - como vimos nos primeiros momentos da eletricidade no Espírito Santo.

Quando a constituição de 1934 modificou o sistema, havia muitas empresas de eletricidade municipais, empresas privadas nacionais e sobretudo empresas estrangeiras, bem como autoprodutoras. As empresas estrangeiras exploravam os serviços nas maiores áreas urbanas, e as empresas privadas nacionais e municipais atuavam nas cidades de médio e pequeno porte.

Já a autoprodução relacionou-se historicamente com as indústrias para seu consumo próprio, sendo que o excedente desta produção era comercializado nos seus arredores - o que em muitos casos, acontece até hoje -. Na maioria das vezes, sem qualquer padronização de linhas de transmissão ou frequência.

A seguir, exploraremos a caracterização dos distintos trajetos percorridos pelos estados federados na criação destas empresas, enquanto diferentes partes do Plano Nacional de Eletrificação inicialmente proposto em 1954. Evidenciando, ainda, as iniciativas das administrações locais com relação a energia elétrica, como pontos de partida para políticas de desenvolvimento econômico regional, que se relacionavam aos interesses de grupos de poder político específicos, em escala local e nacional.

Como demonstraremos, foi deste modo que se deu a diferença do modelo de eletrificação de Minas Gerais, que beneficiou a implementação de uma industrialização pesada concentrada no território, e o modelo do Paraná, que atendia atividades agroindustriais territorialmente dispersas. 
Voltando ao olhar para o setor elétrico nacional, quando finalmente foi criada a Eletrobrás, ela tinha que considerar os modelos estaduais e se adequar a uma pauta - tanto técnica como política e econômica - especificamente local. Ao mesmo tempo, estas diferenças são representações até hoje presentes das desigualdades regionais de desenvolvimento econômico e da infraestrutura elétrica, traços característicos de um modelo federativo brasileiro absolutamente assimétrico.

Mas, antes de tratarmos mais profundamente alguns aspectos da montagem dos setores elétricos de Rio Grande do Sul, Minas Gerais e Paraná, iniciaremos uma breve caracterização conceitual do federalismo moderno.

\subsubsection{Federalismo moderno e o Brasil}

Tomamos como referência, inicialmente, Arretche e Rodden (2005), que caracterizam federalismo como uma forma de organização de Estado em que os entes federados são dotados de autonomia administrativa, política, tributária e financeira necessárias a fim de manter o equilíbrio que se estabelece entre eles para a constituição do Estado Federal. Por se tratar de um pacto entre os entes federados - pacto federativo -, há a implicação de reciprocidade e cooperação entre governo central e governos subnacionais locais.

O federalismo é definido como um meio-termo entre governo unitário, que tem poderes exclusivamente concentrados na União, e uma confederação, na qual o governo central é praticamente inexistente. A confederação é caracterizada como uma aliança entre Estados independentes. O governo central não poderia aplicar as leis sobre os cidadãos sem a aprovação dos Estados, que seriam a fonte da soberania.

A diferença essencial entre federação e confederação é que, na primeira, o governo central possui poder sobre os cidadãos dos Estados ou províncias que compõem a União sem que essa ação tenha de ser acordada pelos Estados. A experiência histórica que gera esse novo conteúdo é a construção do Estado norteamericano a partir de 1787.

Segundo Ricardo Ismael (2005), no processo de ratificação da primeira Constituição estadunidense, destacam-se os ensaios publicados na impressa de Nova York por Alexander Hamilton, James Madison e Jonh Jay, no período de outubro de 1787 e abril de 1788, sob pseudônimo coletivo de Publis. Estes três 
estavam empenhados em argumentar a favor da substituição da confederação pela federação, que estabelecia uma nova orientação para a distribuição territorial do poder político.

O federalismo se transformou ao longo da história, atravessando a fronteira estadunidense e ganhando diversas formas e se adaptando a distintas realidades. Neste trabalho privilegiamos o modelo federalista dos Estados Unidos do século XVIII, já que foi o modelo utilizado pelas constituições brasileiras. Mas debater o federalismo contemporâneo também requer discutir a instituição de um governo federal. O modelo estadunidense privilegiou o pacto federativo como uma associação de estados autônomos submetidos a uma divisão de poderes particulares, sob tal forma que a unidade política é alcançável sem tirar dos entes federados sua independência em relação aos demais. Assim, as autoridades estaduais não se subordinam à autoridade federal, sendo apenas coordenadas e necessariamente independentes em sua respectiva esfera.

Para o cientista político Daniel J. Elazar (1994), dois aspectos principais se destacam no federalismo contemporâneo. Por um lado, uma distribuição constitucional de poder entre o governo central e as unidades governamentais constituintes, de tal forma que todos podem compartilhar do planejamento e implementações de políticas públicas. Por outro, o sistema federal se coloca como uma aliança entre corpos políticos. Desta forma, o arranjo federal é estabelecido e regulado por um pacto, cujas conexões internas refletem um modelo particular de divisão que prevalece entre os participantes, em que cada um reconhece a integridade de cada associado e busca promover unidade.

\subsubsection{Um federalismo brasileiro entre a Primeira República e 1964.}

Os primeiros passos do federalismo brasileiro se deram juntamente com a República em 1889. Contudo, a federação brasileira, ao invés de decorrer do consenso voluntário de seus membros, a reorganização político-institucional do Brasil foi um ato político outorgado, destinado a impedir a fragmentação territorial $^{111}$.

Neste quadro, o poder que deveria caber à união, aos estados e aos municípios, tornou-se o tema mais controverso nas discussões da assembleia

${ }^{111}$ LOBO, 1986. 
constituinte de $1891^{112}$. O modelo de federalismo nacional acabou sendo uma tentativa de cópia do modelo estadunidense, mas norteado por grandes diferenças culturais e sociais existentes por aqui. O país vai conceber o pacto federal, dentro de uma economia agrária, com uma população predominantemente rural, analfabeta e dominada por latifundiários.

É uma época conturbada de história nacional, marcada por diversas revoltas locais, em um contexto de movimentos políticos por maior autonomia das províncias com relação ao governo central e acompanhado pelo deslocamento do eixo econômico do Rio de Janeiro para São Paulo.

Era particularmente a junção de um liberalismo ortodoxo combinado com um federalismo, resultando em um domínio oligárquico dentro dos estados e com uma profunda desigualdade entre as economias regionais. $\mathrm{O}$ pacto identificado como "política dos governadores", baseada, segundo José Murilo de Carvalho (1984), no isolacionismo e total autonomia das Províncias. Tal política vigorou até a reforma constitucional de 1926, que inaugurou o fortalecimento do governo central.

Entretanto, com o conflito proclamado por oligarquias mineiras e gaúchas em 1930, e o estabelecimento do Estado Novo que vai buscar reformas, e, essencialmente, restaurar a posição do governo efetivamente centralizado como principal fator político e social. A Constituição de 1934 refletiu o pacto político resultante do movimento de 1930, entre a oligarquia rural e as insipientes classes média e operária que surgiam com o princípio da industrialização.

Fica claro no período que a expansão dos poderes federais, igualmente à criação de mecanismos de integração entre os entes federados, abriu espaço para a celebração de acordos visando o desenvolvimento das competências das diversas esferas de governo. São várias as instituições e regulamentações nacionais a partir dela, inclusive, como falado anteriormente, a primeira legislação relativa à institucionalização da produção de energia, o Código de Águas.

Com o Estado Novo em 1937, acentuam-se as características de centralização. Bandeiras estaduais são queimadas, governadores estaduais são trocados por interventores nomeados pelo governo central, assembleias e câmaras

${ }^{112}$ CARVALHO, 1984. 
municipais são fechadas. Contudo, a eliminação da descentralização política não reduziria a descentralização fiscal e administrativa.

O fortalecimento da democracia com a queda de Getúlio Vargas em 1946, refletindo o clima mundial pós Segunda Guerra Mundial, juntamente ao processo de urbanização e às transformações da estrutura produtiva, reforçaram tanto os poderes locais como a importância da coordenação via governo federal. Neste momento, formar-se-ia um governo federal com nítida capacidade técnica, regulatória - com a consolidação de agências públicas - e de gestão de políticas públicas. O texto constitucional de 1946 reflete o novo pacto federativo com o estabelecimento da autonomia municipal, a melhor partilha tributária e o peso das competências da União.

A classe operária, que já havia sido incorporada pelo corporativismo do Estado novo, torna-se importante ator político, independente dos governadores mesmo que não independentes do Estado. Uma democracia de massas começava a formar-se, sob o signo do populismo e do nacionalismo.

A união federal, contudo, continua a legislar sobre o trabalho, a política social, a política econômica, segurança interna e externa, ficando as forças policiais subordinadas ao exército nacional. O governo federal agora possui quadros treinados, agências especializadas em planejamento e execução de políticas públicas, expandindo a intervenção econômica ao petróleo, fertilizante, transporte, bem como a eletricidade. Há, também, uma cooperação administrativa e financeira mais clara, e a Constituição reservara tratamento especial para algumas regiões do país, explicitando as competências de cada esfera governamental. A mudança mais contundente é a transferência de recursos entre o governo federal e estadual, característica mais duradoura do federalismo brasileiro. Momento que é definido, segundo Carvalho, como "federalismo cooperativo" (1984 p. 19).

\subsubsection{Entre regionalismo e uma cooperação insulada}

Como vimos, a evolução do federalismo brasileiro desde a Proclamação da República é marcada por alguns acontecimentos envolvendo a relação entre a união e as unidades da federação. Um dos principais acontecimentos é a manifestação regionalista dos estados a fim de obter apoio econômico do governo federal.

A ênfase no aspecto regional decorre das características históricas da federação brasileira. A ação dos estados e regiões do país, que procuraram 
historicamente negociar no Congresso nacional investimentos públicos do governo federal, torna-se relevante no caso do Brasil, tendo em vista os desdobramentos sobre os avanços, e retrocessos, do regime político e do desenvolvimento econômico.

Segundo Ricardo Ismael (2005), o regionalismo pode ser entendido como a mobilização política de grupos dominantes em uma região em defesa de interesses específicos com relação a outros grupos de outras regiões ou dentro do próprio estado. A mobilização regionalista é complexa, e envolve tanto forças sociais no interior como uma articulação com o poder centralizado no Estado. É mobilizado por grupos para obtenção de vitórias particulares no jogo pelo poder político e econômico, dependendo dos interesses dos envolvidos e do caráter progressista ou conservador das condutas ${ }^{113}$.

Há uma literatura sobre economia regional ou economia do desenvolvimento que tem participado ativamente das discussões sobre a dinâmica do federalismo brasileiro. Nesta conjuntura, a estrutura federativa aparece como instrumento para o desenvolvimento, permitindo a integração das economias regionais e assegurando a melhora das atividades econômicas no país.

Por isso, é possível identificar ao longo da história brasileira no século XX que as mudanças no federalismo podem ser apresentadas seguindo as variações nas próprias políticas públicas voltadas para o desenvolvimento regional, realizadas pelo governo federal, instituições regionais e governos estaduais.

Os estados de São Paulo, Minas Gerais e Rio Grande do Sul e os estados do nordeste destacam-se dos demais, impulsionando o fenômeno político. Os grupos destes locais perceberam a importância na federação brasileira, de uma aliança política com o governo federal, de modo que procuram agir nesta direção em diversos momentos da história republicana.

Mas é notoriamente no período de 1945 a 1964 que o país mais avança no processo de regionalização do Estado Federal no Brasil, com a introdução de dispositivos constitucionais relacionados às regiões brasileiras e à criação de instituições federais de âmbito regional.

Uma das características deste período serão as manifestações regionalistas dos estados brasileiros, que Ricardo Ismael (2005) descreve como cooperação

${ }^{113}$ CASTRO, 1989. 
regional insulada. Até 1945, a hegemonia das oligarquias no plano estadual era acompanhada pela hegemonia dos estados no âmbito federal. Os grandes estados conseguiam impor seus interesses na formulação da política econômica, sendo, portanto, os mais favorecidos, ou mais protegidos, na federação brasileira. Para Raimundo Faoro (1992), as pequenas unidades federadas obedeciam porque eram pobres. Assim, um federalismo hegemônico prevalecia, fazendo cair o apoio ao modelo federal.

Contudo, a contar da redemocratização de 1946 até o golpe militar de 1964, o processo de regionalização do Estado Federal se aprofunda, com a introdução de dispositivos constitucionais relacionados às regiões brasileiras e à criação de instituições federais de âmbito regional. Sobre estes aspectos, Ismael (2005) analisa:

\begin{abstract}
"A cooperação dos governos estaduais do Nordeste no contexto federativo foi um dos resultados da regionalização do federalismo brasileiro, sem deixar, porém, de contribuir decisivamente para consolidação desta tendência. As manifestações regionalistas na primeira experiencia federalista (1889-1930), sobretudo de São Paulo e de Minas Gerais, influenciaram, no ambiente nordestino, a emergência de uma ação política semelhante por parte do conjunto dos estados da região. Entretanto, a cooperação regional envolvendo os governos nordestinos será, por assim dizer, institucionalizada apenas com a criação da SUDENE, no final dos anos $60 "(2005$, p. 85).
\end{abstract}

A constituição de 1946 deu início à prática de transferências constitucionais da União para os estados e seus problemas. Além disso, é ampliada a participação da união no planejamento e na execução de políticas públicas voltadas para o desenvolvimento em âmbito estadual, dirigidas para a integração das regiões brasileiras e para a redução das assimetrias regionais - com grande ênfase para o governo Juscelino Kubitschek.

\title{
3.2.4 As empresas estaduais do setor elétrico como recorte do debate regional e federal
}

A importância das empresas de energia elétrica estaduais enquanto instrumentos em um federalismo cooperativo insulado, associa-se à construção das capacidades de articulação de interesses difusos entre os atores políticos e econômicos locais e nacionais, por parte do Estado. Tendo como foco principal, desde a expansão do processo de eletrificação, uma agenda de modernização que 
atendesse aos interesses de acomodação de antigas - e novas - forças na disputa pelo poder político.

Foram várias empresas estaduais que surgiram ainda na década de 1950 e que foram parte desta conjunta, a Empresa Fluminense de Energia Elétrica, em 1954, as Centrais Elétricas de Santa Catarina em 1955, Centrais Elétricas de Goiás em 1955, a Espírito Santo Centrais Elétricas em 1956, a Companhia de Eletricidade do Amapá em 1956, as Centrais Elétricas Mato-Grossenses em 1958, as Centrais Elétricas do Maranhão em 1959.

Contudo, aprofundaremos aqui a conjuntura de criação e consolidação de três empresas criadas neste momento: as Centrais Elétricas de Minas Gerais S/A (CEMIG), Companhia Estadual de Energia (CEEE), do Rio Grande do Sul, a Companhia Paranaense de Energia (Copel).

Estas empresas ocupam lugar de destaque pelo fato de, em primeiro lugar, terem sido as formuladoras dos primeiros planos estaduais de energia nas décadas de 1940 e 1950, inaugurando a prática de planificação do setor - como já vimos anteriormente. E, em segundo lugar, por fazerem parte de algum plano de desenvolvimento econômico regional, conduta igualmente inédita em boa parte do país.

De acordo com os documentos obtidos no Centro de Memória da Eletricidade da Eletrobrás, a partir dos respectivos planos estaduais de eletrificação e legislações estaduais, é possível dizer que, ao lado das iniciativas pioneiras iniciadas pelos capitais privados locais, a formação destes setores elétricos contou desde a origem com a participação das administrações municipais, ou seja, participação estatal.

Como já foi mencionado, até 1934, as prefeituras exerciam não apenas um papel determinante na regulamentação, mas tiveram uma grande participação na produção e na distribuição de energia elétrica, inclusive, com a instalação de usinas termoelétricas. O capital estrangeiro também foi importante para este processo. Em aproximadamente 40 anos (1920 a 1960), desde a instalação da primeira usina do grupo AMFORP ${ }^{114}$, formaram-se setores elétricos isolados, sem nenhuma padronização, mas que conseguiram atender à demanda de eletricidade para os

\footnotetext{
${ }^{114}$ American \& Foreign Power Company - AMFORP.
} 
serviços de iluminação, transporte público e - mesmo que subtendido - as indústrias locais.

O principal causador da reordenação do setor de energia elétrica a nível local foi a assunção de um poder federal como regulador, e sobretudo a escassez de energia que atingiu em cheio o país e os estados como Minas Gerais, Rio Grande do Sul e Paraná, de maneira específica.

Em Minas Gerais, a crise se relacionava ao desenvolvimento de uma indústria siderúrgica. No Rio Grande do Sul, a partir do aumento do mercado consumidor industrial de alimentos, têxteis, dentre outros. Já no Paraná, a crise no abastecimento de energia se relacionava ao crescimento urbano e da agricultura cafeeira.

Mas, em todos os casos, o padrão de acumulação do capital foi alterado, passando a ser comandado por bens de consumo duráveis, bens de capital e de insumos básicos. Neste contexto, o Estado - primeiramente através dos governos locais e posteriormente a nível federal - foi obrigado a responder pelo colapso de um sistema elétrico difuso e na maioria dos casos, precário. A formação dos setores de energia elétrica gaúcho e paranaense são representações destas conjunturas, em associação às dinâmicas políticas locais e ao desenvolvimento de suas economias. A seguir, trataremos dos dois casos.

\subsubsection{Companhia Estadual de Energia Elétrica (CEEE) do Rio Grande do Sul e a} um modelo de desenvolvimento com impacto político nacional.

Os casos do Rio Grande do Sul e do Paraná podem ser pensados como exemplos do desenvolvimento do setor elétrico, que estiveram mais próximos de uma política econômica regional ou local, do que de um projeto nacional de desenvolvimento quando foram geridas. Mas nem por isso deixaram de se relacionar politicamente ao aspecto federativo.

No caso do Rio Grande do Sul até 1943, as plantas da empresa AMFORP em Porto Alegre, Canoas e Pelotas, representavam quase $44 \%$ da capacidade nominal total instalada, respondendo por $70 \%$ de toda energia consumida no Estado. O Estado controlava não mais de $25 \%$ do parque gerador sul-rio-grandense. Todavia, o sistema elétrico gaúcho vinha sendo demandado não só por um racionamento que se espalha pelo estado desde 1942, mas especialmente pelas necessidades de expansão de uma industrialização ligada a ramos tradicionais, 
como alimentícios, calçadistas e de beneficiamento vegetal, junto ao crescimento da atividade urbana e sua modernização.

Importante dizer que, neste momento, o Rio Grande do Sul não esteve à margem do desenvolvimento industrial brasileiro da década, e já ocupava a terceira posição no processo de industrialização nacional desde $1930^{115}$. Além disso, a segunda guerra mundial estimulou igualmente o crescimento dos ramos tradicionais da indústria e, ainda, a diversificação e o desenvolvimento de um setor metalúrgico $^{116}$, o que pressionava ainda mais o setor elétrico dos municípios gaúchos. Mesmo a Companhia de Energia Elétrica Rio-Grandense (CEERG), que atendia Porto Alegre, mantinha uma política de contenção de gastos, impondo à cidade cortes de energia frequentes.

Assim, a busca de uma solução para a escassez de energia elétrica requereu o aumento da participação do Estado por meio da transferência de poder isolado das prefeituras para o governo estadual, a partir da constituição da Comissão Estadual de Energia Elétrica (CEEE) em 1943.

A CEEE foi criada no caminho da racionalização da oferta de energia elétrica mediante o aproveitamento de recursos hídricos através de hidrelétricas e a utilização dos recursos carboníferos do estado por termoelétricas. A atribuição inicial do órgão, neste caso, foi a criação das diretrizes básicas do primeiro Plano de Eletrificação do Estado em 1945, que previa a interligação dos sistemas municipais e a viabilização e elaboração de projetos.

A direção da comissão ficou a cargo do engenheiro Noé de Mello Freitas, que escolheu sua equipe técnica ${ }^{117}$. Esta comissão ampliou a participação do governo do estado não apenas em nível de planejamento, mas também com a geração de eletricidade.

No Plano de Eletrificação do Rio Grande do Sul, consta que o estado tinha a menor capacidade de energia elétrica por habitante e que o motivo dessa situação, além da precariedade na geração, era o baixo atendimento das zonas rurais, onde residia a maioria da população. Assim, a expansão da infraestrutura elétrica no

\footnotetext{
115 IBGE. Recenseamento geral: censo econômico, 1940.

116 PESAVENTO, 1982.

${ }^{117}$ Entre eles Mario Lannes Cunha, primeiro presidente da Eletrosul, subsidiaria da Eletrobrás para a região sul do Brasil.
} 
estado vai se dar sob dois eixos: desenvolvimento industrial e eletrificação rural ${ }^{118}$. Além disso, o plano tece críticas ao planejamento energético nacional, apontando para a necessidade de exploração das reservas carboníferas e dos recursos hídricos. Dentro deste contexto, o governo estadual pressiona pelo aumento da participação do estado na produção e distribuição de energia elétrica, sendo está uma pauta colocada por vários governadores que se seguem, a saber: Walter Jobim (PSD) 1947 e 1951, Ernesto Dornelas (PSD) entre 1951 e 1955, Ildo Meneghetti (PSD) entre 1955 e 1959, e Leonel Brizola (PTB) entre 1959 e 1963.

De acordo com o Plano de Eletrificação, o setor elétrico rio-grandense deveria ser organizado com base em uma sociedade anônima a ser constituída pelos governos municipais, o governo do estado, empresas privadas e consumidores. Caberiam 50\% das ações ao governo estadual, 35\% às prefeituras e 15\% ao capital privado.

O governo gaúcho buscou recursos de diversas fontes para tocar as etapas do plano de eletrificação do estado. A primeira etapa foi entre 1946 e 1950, a segunda entre 1950 e 1955 e a terceira entre 1955 e 1969. Todavia, a maioria esmagadora dos recursos empregados na execução dos planos se deu pela taxa de eletrificação, por empréstimos estaduais a bancos públicos, entidades financeiras multilaterais e grupos internacionais.

\begin{tabular}{|c|c|c|c|}
\hline Fase & $\begin{array}{l}\text { Fonte Hidráulica } \\
\qquad(\mathrm{kW})\end{array}$ & $\begin{array}{c}\text { Fonte Térmica } \\
(\mathrm{kW})\end{array}$ & $\begin{array}{l}\text { Total } \\
(\mathrm{kW})\end{array}$ \\
\hline Primeira Fase & 21200 & 17750 & 45420 \\
\hline Segunda Fase & 98000 & 30000 & 141600 \\
\hline Terceira Fase & 75000 & 187000 & 262000 \\
\hline Total & 194200 & 234750 & 449020 \\
\hline
\end{tabular}

Fonte: elaboração própria desde dados da Centro de Memória da Energia, 2005 e do CEEE, 1944, 1950 e 1964.

O que é importante analisar nesta conjuntura é que, entre a primeira e a terceira fase, há um incremento de $89 \%$ na total produção de energia elétrica, sendo $92 \%$ de energia térmica e $89 \%$ de energia hidráulica.

${ }^{118}$ RIO GRANDE DO SUL (ESTADO). Plano de Eletrificação do estado: plano regional preliminar de eletrificação do Rio Grande do Sul, 1945. 
Em 1952, a CEEE é transformada em autarquia, mediante ato do governador Ernesto Dornelles (PSD), dando autonomia à comissão a fim de captar recursos no Brasil e no exterior, planejar e construir usinas, fiscalizar os serviços de eletricidade e de comunicação, além de promover desapropriações por utilidade pública e realizar encampações decretadas. ${ }^{119}$ Neste momento, a CEEE passa a responder por $80 \%$ da energia consumida no Rio Grande do Sul. A opinião pública e a elite política gaúcha já viam no horizonte a incorporação da Companhia de Energia Elétrica Rio-Grandense (CEERG), subsidiária do grupo AMFORP.

A partir de 1958, lança-se as bases para o confisco da companhia, sem indenização ao grupo AMFORP/BOND \& SHARE. Esta situação seguia a tendência de manifestação de grupos nacionalistas do país, que defendiam a estatização de empresas dos setores básicos da economia. Os atos ocorreram durante o governo de Leonel Brizola (1958-1962), atingindo empresas estrangeiras - não só do setor de energia. Assim, em maio de 1959 o governo gaúcho encampa e confisca os bens da Companhia de Energia Elétrica Rio-Grandense, subsidiária da AMFORP.

Leonel Brizola foi eleito deputado federal em outubro de 1954 e no ano seguinte prefeito de Porto Alegre. Foi seu desempenho à frente da prefeitura da capital gaúcha que o credenciou Brizola para disputar com êxito o governo estadual, pelo Partido Trabalhista Brasileiro (PTB) em outubro de 1958. Conferindo, ainda, prioridade ao desenvolvimento industrial, baseado em investimentos do capital privado nacional e do governo estadual. ${ }^{120}$

Empossado em janeiro de 1959, deu início a uma administração voltada fundamentalmente para os problemas do desenvolvimento econômico, considerando a crise que passava a economia gaúcha, como consequência de sua marginalização no âmbito da política econômica implantada pelo governo Kubitschek. E uma das principais bandeiras de Brizola para superação dos problemas econômicos gaúchos, era uma forte intervenção do Governo estadual na economia, o que passava pela encampação da CEERG.

\footnotetext{
${ }^{119}$ Rio Grande do Sul. Lei estadual nº1744, artigo 2, letra K.

${ }^{120}$ CPDOC (FGV). Dicionário Histórico-Biográfico Brasileiro On-line: Leonel Brizola. Rio de Janeiro, 25 out. 2020. Disponível em: http://www.fgv.br/cpdoc/acervo/dicionarios/verbetebiografico/leonel-de-moura-brizola
} 
A campanha pela encampação ganhou ainda mais ímpeto durante a presidência de João Goulart (1961-1964) ${ }^{121}$. Neste momento, diversas organizações populares, como a Frente de Mobilização Popular, a União Nacional dos Estudantes e o Comando Geral dos Trabalhadores, empreenderam uma ofensiva contra a atuação de empresas estrangeiras que controlavam o fornecimento de serviços públicos nos principais centros urbanos do país.

Marco Antônio Medeiros da Silva (2015) faz uma excelente abordagem sobre estes momentos no Rio Grande do Sul. Para ele, a desapropriação da Companhia de Energia Elétrica Rio-Grandense (CEERG) aos 103 dias de governo Brizola, foi a concretização de uma promessa de campanha eleitoral de solucionar o problema crônico de abastecimento e de interrupção do fornecimento de energia elétrica. Leonel Brizola considerava a crise pela qual passava como consequência de sua marginalização no âmbito da política econômica implantada pelo governo Juscelino Kubitschek, defendendo, assim, o desenvolvimento da industrialização estatal com intervenção direta do governo estadual na economia.

Esta ação se relacionava também ao quadro de estagnação de planejamento do desenvolvimento da agricultura, indústria e de outros setores da economia gaúcha. Foi uma iniciativa que se somou à política de encampações que já era praticada pela Comissão Estadual de Energia Elétrica (CEEE), que já havia adquirido pequenas empresas privadas e municipais, prática que representou $70 \%$ do total da energia elétrica controlada por autarquias estaduais.

A dinâmica de encampação do governo Leonel Brizola no Rio Grande do Sul foi um ato ousado do governador, antecedendo até mesmo as expropriações das empresas estrangeiras realizadas por Fidel Castro, em Cuba. Obtendo também amplo apoio da opinião pública e da maioria dos parlamentares da Assembleia RioGrandense. Porém, mais tarde, representou o ponto de cisões internas no PTB nacional, tornando inclusive o governador do Rio Grande do Sul um dos responsáveis pelo agravamento das relações com os Estados Unidos. Brizola, neste aspecto, ao ser interpelado pelo presidente Juscelino Kubitschek, explicou tratar-se de um processo conduzido dentro da lei, sendo o poder judiciário, concedente ao Estado do Rio Grande do Sul, da posse da CEERG, portanto, de um ato arbitrário do Executivo.

${ }^{121}$ É bom lembrar que o presidente era cunhado de Leonel Brizola. 
Acreditamos que a encampação da CEERG significara um divisor de águas na gestão pública regional com influências profundas no cenário nacional. As encampações representaram o que Ricardo Bielschowsky (2000) chamou de "desenvolvimento reformista", um ciclo ideológico que foi marcado pela formação do "complexo nacional-popular" que marca a política brasileira desde então.

3.2.6 Companhia Paranaense de Energia (COPEL): entre influência política paulista e o efeito urbano da agroindústria

No Paraná, a eletricidade chega em 1890, como consequência de um contrato com a empresa Companhia Água e Luz de São Paulo para iluminação pública na capital paranaense, Curitiba. 20 usinas são instaladas até 1920, dentre elas, 13 térmicas e 7 hidráulicas. Além de usinas municipais e privadas, o estado contava ainda com empresas autoprodutoras, como outra empresa paulista, a Indústrias Reunidas Matarazzo, as Indústrias Brasileiras de Papéis e a Companhia Mate Laranjeiras.

Neste momento, o setor de energia elétrica do Paraná detém três características principais: a reduzida participação das administrações locais, a presença de empresas dos estados vizinhos, como São Paulo, e a acentuada descentralização, que se caracterizava pela ausência de uma rede de transmissão e de distribuição capaz de integrar as usinas localizadas em pontos dispersos do seu território.

Em 1928, o governador Caetano Munhoz da Rocha (PR) assina contrato com a Empresas Elétricas Brasileiras representante da AMFORP no Paraná. Por este contrato, a empresa adquiriu a South Brazilian Railways Limited e assim constituiu a Companhia Força e Luz do Paraná (CPFL), empresa está que deteve o monopólio dos serviços.

Até a década de 1930 as atividades extrativas e agroindustriais eram as que mais contribuíam para a formação do mercado de consumo de eletricidade, devido seu efeito urbanizador. Cidades como Palmas, Lapa, Castro e Pota Grossa cresceram apoiando-se nas atividades de pecuária, Campo Mourão e Cascavel em função da extração de mate; Pato Branco e Francisco Beltrão em consequência da exploração dos pinheirais.

É assim, que a madeira se torna o principal elemento de desenvolvimento econômico. A extração da madeira e suas indústrias correlatas - papel, papelão e 
mobiliário - passaram a fazer parte da economia de grande número de municípios do Paraná, disseminando a industrialização pelo interior do estado ${ }^{122}$.

Núcleos urbanos como estes, criados a partir da agroindústria extrativista, representavam os principais consumidores de energia elétrica. Isso fica mais evidente quando se constata que $75,1 \%$ da força motriz da indústria era de máquinas a vapor. Da mesma forma e no mesmo momento, se inicia a fase do café como um dos principais elementos da pauta econômica do Paraná, fruto da expansão da lavoura paulista no Norte paranaense. Na década de 1940, com a ocupação do chamado Norte Novo e o consequente aumento das lavouras de café, passou a ser o produto de maior importância da economia paranaense ${ }^{123}$.

A cafeicultura foi igualmente um agente importante para o mercado de energia elétrica, especialmente, com o seu dinamismo econômico e com sua relação com a colonização de diversas partes do interior do estado. Este processo de colonização foi intensificado com o governo Manuel Ribas (PSD) entre 1937 e $1945^{124}$, que aproveitou grandes áreas de terras devolutas para empreendimentos de programas de colonização.

Contudo, mesmo com essa expansão das áreas habitadas e da atividade econômica, não interessou a CPFL fornecer energia aos novos núcleos urbanos no norte do estado, pois, de um lado, não possuía as concessões desses municípios e, por outro, a interligação entre as redes elétricas era precária e requereria um grande volume de investimento, incompatível com a política de contenção de investimentos adotada pela AMFORP no Brasil. Foi assim que a escassez de energia no estado do Paraná levou a atuação governamental à busca pela racionalização da oferta de energia do território paranaense.

A principal ação estatal foi a criação do Serviço de Energia Elétrica entrando em funcionamento em 1947 -, órgão vinculado à Secretaria de Viação e Obras Públicas, e que tinha por finalidade regularizar o fornecimento de energia elétrica no estado. A criação deste serviço foi no governo Moyses Lupion, (PSD),

\footnotetext{
122 RODRIGUES, 2009, p. 01-17.

${ }^{123}$ MIGLIORINI, 2006.

${ }^{124}$ Ribas iniciou, então, um período de 13 anos à frente do governo estadual, durante o qual tornouse fundador (1933) e presidente honorário da Partido Social Democrático (PSD) do Paraná. Foi eleito governador pela Assembleia Estadual Constituinte de 1935 (na qual o PSD detinha a maioria, com 20 representantes), e voltou a ocupar a interventoria durante o Estado Novo (1937-1945). CPDOC (FGV). Dicionário Histórico-Biográfico Brasileiro On-line: Manuel Ribas. Rio de Janeiro, 28 out. 2020. Disponível em: http://www.fgv.br/cpdoc/acervo/dicionarios/verbete-biografico/ribasmanuel-interv-pr
} 
que governou pela primeira vez entre 1947 e 1951, com o início do plano de eletrificação estadual sendo desenhado.

Importante destacar que Moyses Lupion vai estar associado, como quase a totalidade dos partidos da época, a um segmento de poder que representava interesses empresariais do setor madeireiro, e especialmente vinculado às lideranças e às estratégias do PSD. Segundo Evandir Condato (1999), o período compreendido entre 1945-1950 aponta o udenismo e o lupionismo como desdobramentos da oposição entre PSD/UDN, influenciados igualmente pelo nacionalismo e pelo regionalismo.

No entanto, o governo de Lupion apresentou-se como uma vertente do conservadorismo, um pouco mais ao centro, se comparado ao radicalismo udenistas. Ao ser apresentado como liderança regional, o Moises Lupion vinculase às políticas de massas, mas sem apresentar o mesmo carisma de Vargas. O 'lupionismo' foi muito mais o resultado de uma prática incentivada pelo PSD do que um fenômeno com características populistas.

Além da dimensão regionalizada da ação política, os discursos sobre a modernidade eram a tônica da prática lupionista. Neste sentido, Lupion teve a sua imagem ligada à de um empresário bem-sucedido e engajado na moderna corrente de desenvolvimento econômico, que, por sua vez, estava fortemente relacionado com o início do planejamento de um setor elétrico estatal.

Mesmo assim, o primeiro Plano de Eletrificação do Paraná, chamado PlanoElétrico, não teve a intenção de alterar a estrutura do sistema elétrico. Recomendando apenas a instalação de usinas e grupo de geradores de pequena potência nas localidades com problemas de abastecimento, este plano foi executado através da implementação de $87 \%$ de energia proveniente de origens térmicas e $13 \%$ hidráulicas.

O posterior Plano Hidroelétrico Paranaense teve mais impacto, mas foi proposto já no mandato do sucessor de Moises Lupion, Bento Munhoz da Rocha Netto (UDN), entre 1951 e 1956. Este Plano se dividiu em duas fases: a primeira entre 1951 e 1956, consistia na construção de usinas isoladas e em lugares onde as grandes centrais elétricas poderiam ser antieconômicas; e a segunda fase, entre 1955-1956, que consistia na implantação de quatro centrais geradoras, somando $152.880 \mathrm{~kW}$. 
Como os custos das obras da segunda fase eram maiores que a capacidade financeira do governo do estado, foi criado o Fundo de Eletrificação do Estado do Paraná (FEEP). Seu objetivo era financiar a construção, a ampliação e a conservação das obras de eletrificação do estado.

A mesma legislação que criou a $\mathrm{FEEP}^{125}$ autorizou o governo estadual a organizar empresas de economia mista para a construção e a exploração de centrais geradoras de energia elétrica. Assim foi criada, em 1954, a Companhia Paranaense de Energia Elétrica (COPEL), empresa de economia mista destinada a planejar, construir e explorar sistemas de produção, transmissão e comércio de eletricidade.

Os primeiros diretores da empresa foram Themistocles Linhares, presidente, Pedro Viriato Parigot de Souza ${ }^{126}$, diretor técnico, e Heraldo Correa, diretor administrativo. Contudo, esta primeira administração da Copel deixou a empresa, ainda em 1956, ainda em fase de estruturação.

Seria apenas no segundo governo de Moyses Lupion (PSD), entre 1956 e 1960, que o Plano Hidrelétrico Paranaense tomaria um novo rumo. Em mensagem à assembleia no início do seu segundo mandato, Lupion explicitava os pontos básicos da sua política econômica, baseada no papel de destaque à agricultura no conjunto da economia ${ }^{127}$.

Importante notar que esta referência de Lupion a uma política econômica baseava-se nas negociações entre o governo, estados vizinhos e a união, articulando em torno de um projeto econômico específico para a região sul. Foi assim que o governo federal apoiou prioritariamente o desenvolvimento das indústrias em São Paulo e financiou as atividades agrícolas do Paraná. E foi dentro deste contexto que a eletrificação do estado ocorreu entre 1950 e 1960.

Um bom exemplo dessa situação foi o convênio assinado entre Moyses Lupion e o governador de São Paulo, Jânio Quadros ${ }^{128}$, para o aproveitamento hidrelétrico do rio Paranapanema em 1959. Esse convênio previa a construção da hidroelétrica do Paranapanema (USELPA), em que o governo paranaense se

\footnotetext{
${ }^{125}$ PARANA. Lei estadual $\mathrm{n}^{\circ} 1384$, de 10 de outubro de 1953.

126 Pedro Viriato tornou-se vice-governador do Paraná em 1971. CPDOC/FGV. Dicionário Histórico-Biográfico Brasileiro On-line: Pedro Viriato Parigot de Sousa. Rio de Janeiro, 25 out. 2020. Disponível em: http://www.fgv.br/cpdoc/acervo/dicionarios/verbete-biografico/pedroviriato-parigot-de-sousa

127 BRAVIN et al., 2015.

128 Deputado Federal eleito pelo Paraná entre 1959 e 1961.
} 
comprometia com apenas $40 \%$ do capital da usina, restante ficava a cargo da União, em troca, seria assegurado o fornecimento de energia ao estado.

É possível dizer, observando estas condições, que está na dinâmica econômica a localização um dos principais elos regionais e que consolidava igualmente a integração produtiva com a de São Paulo, configurando-se uma complementaridade produtiva inter-regional ${ }^{129}$.

Neste contexto, a Companhia Paranaense de Energia Elétrica (Copel), ainda em fase de construção e extremamente fragilizada econômica, política e administrativamente, foi recuperada. Em 1962, foram redefinidas as bases de financiamento da empresa através da criação do Fundo de Desenvolvimento Econômico (FDE), além disso, a companhia conseguiu replanejar a base de cobrança de tarifas, posta em prática em 1964.

No mesmo ano, após o golpe de Estado de 1964, com a compra das empresas AMFORP pelo governo federal, a Copel encampa a Companhia Paranaense de Força e Luz (CPFL) e as usinas que faziam parte da DAEE-PR. Em 1966, passa integrar o Comitê de Estudos Energéticos da Região Sul. Já em 1970, a Copel vai deter $56,5 \%$ do mercado paranaense de eletricidade, superando autoprodutoras e empresas privadas do setor ${ }^{130}$.

As transformações ocorridas na base produtiva do Paraná, igualmente, que na infraestrutura elétrica nas décadas de 1960, 1970 e 1980, deram um grande destaque à modernização, e consequentemente, ao desenvolvimento de unidades agroindustriais, que foram de grande importância para a formação de parques industriais nas áreas rurais do estado.

3.2.7 A Companhia Energética de Minas Gerais (CEMIG) e um projeto nacional de desenvolvimento

Durante a década de 1940, a população do Estado de Minas Gerais era estimada em 6.736 .416 habitantes, representando $16,45 \%$ da população brasileira. Constatava-se a migração de boa parte de sua população rural para outros estados federados, estimando-se em 900 mil habitantes emigrados entre 1872-1940.

${ }^{129}$ TRINTIN E IZEPÃO, 1993.

${ }^{130}$ ANDRIOLI, 1975. 
Ao problema de uma migração acentuada, junta-se a dificuldade da expansão de uma infraestrutura elétrica na zona rural. Isso pode ser explicado pela dispersão da população, pelo tamanho das propriedades rurais e, sobretudo, pela inexistência de uma entidade especializada no planejamento e realização da eletrificação rural, considerando a falta de iniciativa das empresas privadas.

Duas questões são chaves para esta situação: (1) a reclamação das empresas sobre a legislação reguladora do setor, como o Código de Águas (1934); e (2) a taxa de lucros na área de concessão da Companhia Força e Luz de Minas Gerais (CFLMG) que vinha crescendo, e novos investimentos não necessariamente eram considerados convenientes.

Mas o projeto de construção da cidade industrial de Contagem representava um aumento considerável no consumo de energia elétrica. O que provocaria uma intervenção do governo mineiro na geração de energia que, além da construção de hidroelétricas e da organização institucional do setor, levou a criação do Departamento de Águas e Energia Elétrica de Minas Gerais (DAEE-MG).

Foi em novembro de 1949 que o governador Milton Campos (UDN) estabelece as bases para a criação de empresas de economia mista que pudessem atuar na necessária intervenção do Estado no setor de energia elétrica, através da Lei estadual $\mathrm{n}^{\circ} 510$ de 30 de novembro de 1949. A lei autorizava o governo mineiro a subscrever ações dessas empresas, fazer empréstimos e dispor de patrimônio, além de destinar 3\% da receita tributária estadual, durante 15 anos, ao fundo de eletrificação do Estado.

Importante apontar que um esboço inicial de um Plano de Eletrificação Mineiro - que ficaria pronto em 1951 - já havia sido realizado pelo engenheiro Lucas Lopes ainda em 1946, durante a gestão do antecessor de Milton Campos, Benedito Valadares (PSD), e colocava o planejamento como uma das linhas mestras de um modelo de desenvolvimento a ser aprofundado nos anos seguintes.

Lucas Lopes também vai elaborar as diretrizes da política de eletrificação mineira, propondo que os objetivos do Estado deveriam ser enquadrados na perspectiva do Plano Nacional de Eletrificação, partindo do pressuposto da necessidade da intervenção governamental no setor elétrico para o crescimento rápido e racional desta indústria, incentivando a iniciativa privada e suplementandoa, ou substituindo-a, quando deficiente ou inexistente. Segundo ele, 
“(...) é dever do Governo definir com objetividade as obras que pretende executar em prazos determinados, para que a iniciativa privada possa também fixar os seus objetivos sem o risco de perturbações por parte da iniciativa governamental" (CBE, 1950, p. 47).

A dimensão de Lopes para o projeto de desenvolvimento mineiro e brasileiro corrobora as análises de Daniel Barbosa e Lidiany Barbosa (2010) sobre o papel dos engenheiros na década de 1930, como profissional de corte ideal para os desígnios estatais. Pode-se perceber que, tanto na organização do serviço público, como na formulação dos órgãos deliberativos e consultivos definidores de políticas públicas de desenvolvimento econômico, há uma expressiva inserção dessa categoria.

$\mathrm{O}$ caso mineiro, especificamente, traz como processo significativo à formação de um corpo técnico estadual predominantemente formado por engenheiros, que entra na órbita da ocupação da administração pública. Esta categoria profissional será em Minas Gerais, de um modo muito específico, a elite técnica portadora de um discurso "modernizante" (BARBOSA E BARBOSA, 2010, p. 114).

Mas a defesa da intervenção do Estado no setor de energia elétrica por parte de Lopes é também o discurso de uma fração da elite econômica mineira que começa a expressar o ideário desenvolvimentista. Sob este aspecto, já em 1955, o presidente da Associação Comercial e Empresarial de Minas, Paulo Macedo Gontijo, em discurso na cidade de Governador Valadares, por ocasião da inauguração da Usina Hidroelétrica de Tronqueiras, diz:

\footnotetext{
“Tronqueiras não é apenas uma Usina elétrica a se inaugurar. Não é tão pouco a garantia de progresso do maravilhoso Vale do Rio Doce. Muito mais do que o marco da civilização plantado no aconchego suave dessas matas milenares ou no dorso sonolento do rio manso é a mensagem de realizações de gente mineira, da capacidade criadora do homem da montanha, e, sobretudo, a demonstração de que os problemas econômicos tão atrevidamente postos por Minas no cenário nacional, nestes últimos anos, encontram na fronteira da própria Minas os seus mais seguros realizadores" (GONTIJO, 1955, p. 6).
}

Sob este cenário, a Centrais Elétricas de Minas Gerais S/A (CEMIG) fundada em 1952 - tem significado especial enquanto instituição. Contou em sua equipe com Lucas Lopes, primeiro presidente da empresa entre 1952 e $1953^{131}$;

${ }^{131}$ E presidente do Banco Nacional do Desenvolvimento Econômico (BNDE) entre 1956 e 1958, Ministro da Fazenda 1958 a 1959. 
John Cotrim, diretor da empresa entre 1952 e $1954^{132}$; Mário Bhering, presidente da CEMIG entre 1954 e 1955; 1966 e 1968; 1983 e $1984^{133}$ e João Camilo Pena, presidente da CEMIG de 1969 a $1975^{134}$.

Mauro Thibau, ex-Ministro de Minas e Energia no governo militar (19641967) e participante da primeira diretoria da CEMIG, analisa um pouco destas contribuições, sobretudo a de Lucas Lopes:

\begin{abstract}
"A singularidade da direção da Cemig resultou de uma conjunção rara de fatores que por vezes acontece [...] Assumiu o governo de Minas um homem com uma mentalidade diferente Juscelino Kubitschek. Como principal assessor e, especificamente, executor da parte mais importante da administração, de que dependeria, sem dúvida, o êxito da pretensão de se afirmar nacionalmente e chegar à presidência da República, foi designado Lucas Lopes. ${ }^{135}$
\end{abstract}

Necessário também examinar o trabalho realizado por Lucas Lopes no interior da Comissão Mista Brasil-Estados Unidos (CMBEU), bem como no Banco Nacional de Desenvolvimento Econômico para atender projetos da CEMIG. O depoimento de John Cotrim ${ }^{136}$ versa neste sentido:

\begin{abstract}
“[...] Lucas Lopes, ao mesmo tempo que era da Cemig, integrou a Comissão Mista. Porque Juscelino, que era muito vivo, quando viu que a comissão se constituiria e objetivando garantir benefícios para o seu Estado, foi ao Getúlio e disse: "Quero um homem meu na comissão." E designou Lucas Lopes, que depois foi para a presidência do (Banco Nacional de Desenvolvimento Econômico) BNDE e começou a dar suporte aos programas de interesse de Minas Gerais".
\end{abstract}

A participação de Lucas Lopes na CMBEU esteve além do papel de técnico do governo brasileiro. Lopes atuou notadamente, visando garantir os recursos e dar continuidade ao projeto de desenvolvimento em Minas Gerais.

Nas suas próprias palavras, apenas permaneceu "na Comissão Mista porque podia fazer lobby a favor dos projetos mineiros. Modéstia à parte, eram os projetos que me pareciam melhores para o Brasil"137. Este cenário também é reforçado, pelos telegramas trocados entre Juscelino Kubistchek (PSD) e Getúlio Vargas, em

\footnotetext{
${ }^{132}$ E primeiro presidente da Furnas Centrais Elétricas S. A. em 1957.

${ }^{133}$ E diretor Eletrobrás entre 1967 e 1975, e, 1985 e 1990.

${ }^{134}$ Ministro da Indústria e Comércio (MIC) no governo militar do general João Batista Figueiredo de 1979 a 1984 e em 1985, assumiu a presidência de FURNAS.

${ }^{135}$ CENTRO DA MEMÓRIA DA ELETRICIDADE NO BRASIL, 1997.

${ }^{136}$ Fala registrada em: A Eletrobrás e a história do setor de energia elétrica no Brasil: ciclo de palestras/Centro de Memória da Eletricidade no Brasil; coordenação Renato Feliciano Dias. Rio de Janeiro, 1995.

${ }^{137}$ CENTRO DA MEMÓRIA DA ELETRICIDADE NO BRASIL, 1991, p.121.
} 
que demonstram "a interferência do governo federal em favor dos projetos industrializantes mineiros foi capital" ${ }^{\text {138. }}$.

Assim, a execução de projetos de desenvolvimento regional como o mineiro, demonstra como é necessária a identificação dos atores também denominados agentes do desenvolvimento ou como já identificamos, elites modernizadoras. Acima de tudo, a cultura de desenvolvimento demonstrada por estes agentes são elementos essenciais para o êxito de um projeto de desenvolvimento.

Podemos dizer, inclusive, que a ligação entre a política energética mineira e um projeto nacional de desenvolvimento não se coloca apenas na escolha dos nomes de engenheiros de Minas Gerais para formular a meta energética nacional durante os governos dos regimes democráticos e ditatoriais entre 1950 e 1990, ou mesmo como um mero favoritismo de uma presidente da República mineiro Juscelino Kubitschek ${ }^{139}$ - ao seu Estado de origem ${ }^{140}$. A trajetória de Minas Gerais, na construção de um setor de energia elétrica estatal, foi principalmente o direcionamento a nível nacional de uma política de construção de um Estado empreendedor e capitalista nacional, tanto em seus objetivos, orientados para o desenvolvimento industrial de base, quanto pela dimensão das unidades geradoras planejadas e construídas, todas de grandes proporções.

Assim, o setor elétrico mineiro se comprometeu com a implantação de infraestrutura energética para a indústria pesada, segundo as diretrizes do desenvolvimento econômico dominantes na época. $\mathrm{O}$ desenvolvimento industrial de Minas Gerais vinculou-se não apenas à concepção dominante da necessidade de ruptura com a tradição agrária enquanto herança colonial, mas também à prioridade em explorar os recursos naturais, sobretudo, para a indústria metalúrgica.

De acordo com Wilson Cano (2015), eram muitos os efeitos do Plano de Metas no contexto mineiro. No intervalo entre 1950 e 1960, a participação da indústria de Minas Gerais no setor de cimento saltou de 15,2\% para 23,8\%,

\footnotetext{
${ }^{138}$ SILVA, 2013, p. 16

${ }^{139} \mathrm{Na}$ presidência de Juscelino Kubitschek (PSD), a política econômica procurou restabelecer condições para a implementação dos compromissos estatais desenvolvimentistas assumidos a partir do Estado Novo. Kubitschek, ainda em seu mandato de governador mineiro, em janeiro de 1951, teve como eixo de ação o binômio "energia e transportes". Para Lilia Schwartz e Heloisa Starling, o segredo de Juscelino para conquistar a máxima simpatia dos grupos sociais que estariam envolvidos no projeto nacional, está no fato de conseguir transformar o Plano de Metas em um "projeto de um Brasil Possível" (SCHWARTZ e STARLING, 2015 p. 417).

${ }^{140}$ CENTRO DE MEMÓRIA DA ELETRICIDADE NO BRASIL, 2005, p. 14.
} 
totalizando um crescimento de 8,6\%; no setor siderúrgico, a produção de aço saltou de $21,6 \%$ para $31,9 \%$, totalizando um crescimento de $10,3 \%$. O desenvolvimento do setor minero-metalúrgico se consolidou ao longo dos anos 1950, com o surgimento de empresas como Usiminas, Mannesman, dentre outras, além do alargamento das empresas mais antigas como a Belgo-Mineira, a Vale do Rio Doce e Acesita. Entre os maiores consumidores de energia elétrica da CEMIG nos anos 1950 estavam a Mannesman (siderurgia) com 45.000 KW e a Belgo-Mineira com (siderurgia) $10.000 \mathrm{KW}$.

\subsubsection{A influência mineira no plano nacional}

Quando chega à presidência em 1956, Juscelino Kubitschek procura estabelecer as mesmas condições criadas em Minas Gerais para a implementação dos compromissos estatais desenvolvimentistas ${ }^{141}$. E não seria estranho que a lógica do planejamento energético ganhasse mais impulso, especialmente em seu projeto desenvolvimentista batizado "Plano de Metas". Este plano foi o programa de desenvolvimento econômico do governo, baseando-se em diagnósticos do Grupo CEPAL-BNDE sobre as demandas futuras da economia brasileira. Sob o impulso do Plano de Metas, houve uma intensa e rápida diferenciação industrial, articulada pelo Estado.

Maria da Conceição Tavares (1981) realça dois fatos essenciais da economia brasileira entre 1956 e 1961: o aumento da participação do governo nos investimentos e a entrada de capital estrangeiro privado e oficial para desenvolver vários setores.

Neste contexto, é proposto também o projeto de lei 4.280/54, que autorizava a União a constituir a Eletrobrás - Centrais Elétricas Brasileiras S.A., que só seria aprovada em 1961, no breve Governo Jânio Quadros. Mas sua importância fica registrada em fala do Prof. José Luiz Lima:

\footnotetext{
"O planejamento do setor de energia elétrica seria consagrado pelas reformas institucionais e políticas implementadas em meados da década de 1960. Esse instrumental, essa capacitação conquistada na primeira metade da década, haveria de informar todos os planos desenvolvidos mais tarde pelo governo federal no que diz respeito à infraestrutura
}

141 Como analisam Lilian Schwartz e Heloisa Starling (2015, p. 417), o segredo de Juscelino Kubitschek, para conquistar a máxima simpatia dos grupos sociais que estariam envolvidos no projeto nacional, está no fato de conseguir transformar o Plano de Metas em um "projeto de um Brasil possível. 
energética, e que foram elaborados a partir da Eletrobrás" (Centro de Memória da Energia, 1995 p. 70)

Nas políticas adotadas nos anos de 1952 a 1961, a meta da expansão das indústrias de base foi uma das que mais ganharam atenção e investimentos, crescendo significativamente em relação ao período anterior, como corrobora Lafer (1970):

"O setor de indústrias de base, que absorvia $20,4 \%$ dos investimentos
inicialmente contemplados pelo Plano de Metas era um dos setores
cruciais para se atingir a vigorosa política de industrialização de que
falava Kubitschek na sua campanha eleitoral de 1955 . Os resultados do
setor, no conjunto, mostram que esse objetivo foi atingido, pois o ritmo
de crescimento da produção industrial aumentou de mais de $96 \%$ sobre
1955 - índice do volume físico da produção industrial - crescimento
que se compara muito favoravelmente com o índice de $1952-1955$ que
foi de $42 \%$. Por outro lado, a produção industrial diversificou-se,
ganhando maior ênfase o setor de bens de produção [...] (1970, p. 45)".

O setor de indústrias de base entre 1955 e 1959 recebeu 55,4\% dos equipamentos estrangeiros que entraram como investimento direto via Instrução $113^{142}$, o equivalente a $93,6 \%$ do total, se forem desconsiderados os investimentos em setores que não faziam parte do Programa de Metas. Estes dados confirmam a importância do desenvolvimento deste setor nas metas do governo Kubitschek.

Contudo, ao final do governo Kubitschek, ocorre um importante ponto de inflexão. Entre os anos de 1961 final do seu governo e 1964, governo João Goulart, sob uma conjuntura econômica complicada e uma instabilidade política persistente, rompeu-se a dinâmica nacional-desenvolvimentista.

Como analisa Eduardo Raposo (2011), o governo Juscelino não conseguiu abalar as contradições fundamentais do nosso desenvolvimento social e político. Permaneceu sem mudanças ou rupturas, com a divisão entre grupos e corporações que recebiam recursos políticos e econômicos administrados pelo Estado, e os mesmos organizados, que continuaram excluídos do contrato social que vinha prevalecendo na organização política do país, seja do ponto de vista nacional ou regional.

142 Instrução $\mathrm{n}^{\circ} 113$ permitiu a importação de bens de capital à taxa "livre" de câmbio por investidores estrangeiros, caso esses investidores aceitassem, como forma de pagamento, a participação no capital próprio da empresa que importasse o equipamento. A Carteira de Comércio Exterior (CACEX) do Banco do Brasil, sucessora da Carteira de Exportação e Importação (CEXIM), julgava se os investimentos se enquadravam nas suas prioridades para a concessão dos benefícios da Instrução $\mathrm{n}^{\circ} 113$, embora no caso de bens de capital para produção de bens enquadráveis nas três primeiras categorias de importação a aprovação fosse automática (CPDOC/FGV, Acessado em 19/12/2019). 
Diante da polarização e do confronto entre forças políticas, conflitos que expressavam a falta de consenso sobre as regras que deveriam regular a vida política nacional, as elites industriais aliam-se às outras frações dominantes, porém heterogênicas, constituindo um golpe de Estado que depõem o presidente Goulart.

É necessário dizer que em todo um período desenvolvimentista até 1964, embora de forma intermitente, promove o avanço da tecnologia das estruturas econômicas e das instituições estatais. Esta dinâmica se organizou em torno do poder econômico do Estado, com infraestrutura e indústrias de base. O capital estrangeiro com indústrias dinâmicas e o capital nacional com indústrias tradicionais.

Neste momento, o Estado aparelhou-se em termos organizacionais, de coordenação econômica e planejamento, programas de metas e planos setoriais, políticas de financiamento estatal, de fomento e comércio exterior, normas e regulamentações específicas de preços, tarifas públicas, salários, concentração da economia e tecnologia. E, sobretudo, passando a utilizar o desempenho econômico como critério básico de legitimidade, em substituição aos clássicos instrumentos e valores de representação política.

A partir daí, as metas estabelecidas para a indústria de base foram atingidas, bem como o proposto pelo Plano para as áreas de infraestrutura energética. A expansão da capacidade instalada significou alcance dos objetivos de aumento de produção, elevando a capacidade instalada em $3.500 .000 \mathrm{~kW}$ em 1956, $5.000 .000 \mathrm{~kW}$ em 1960, e $9.000 .000 \mathrm{~kW}$ em $1965^{143}$.

Esta fase compreendeu a transição para um sistema elétrico estatal, seja no plano federal ou estadual. Tendo como postos-chave a criação de Furnas Centrais Elétricas S.A (Furnas) em 1957 - responsável pela UHE Furnas e destinada ao atendimento do crescimento da demanda de energia elétrica das cidades industrializadas do Sudeste, e em 1962 -, a criação da Centrais Elétricas Brasileiras - S.A (Eletrobrás), como empresa pública, controladora do Fundo Federal de Eletrificação - responsável pela concepção e realização de estudos e projetos, operação de usinas produtoras, linhas de transmissão e pela distribuição de energia elétrica nacional através do controle direto ou indireto de várias empresas regionais.

\footnotetext{
${ }^{143}$ Para comparação, a capacidade total do sistema elétrico em 2016 foi de $150.400 .000 \mathrm{~kW}$.
} 
3.2.9 O setor elétrico como recorte de um protagonismo político regional no desenvolvimento econômico nacional

Como vimos até aqui, a importância das empresas de energia elétrica estaduais enquanto instrumento da relação entre regionalismo e de um federalismo cooperativo insulado, associa-se à construção das capacidades de articulação de interesses difusos entre os atores políticos e econômicos, nacionais e regionais.

Do ponto de vista econômico, em Minas Gerais o foco se relaciona ao desenvolvimento de uma indústria siderúrgica. No Rio Grande do Sul, ao aumento do mercado consumidor industrial de alimentos, têxteis, dentre outros. Já no Paraná, o abastecimento de energia se relaciona ao crescimento da agricultura cafeeira e ao crescimento urbano. Na dinâmica política, isto representava uma agenda de modernização que se ligava diretamente à expansão do processo de eletrificação em atendimento aos interesses de acomodação de novas forças políticas, na disputa pelo poder da administração pública local e nacional.

Fica visível, então, a ascensão e o protagonismo do governador Leonel Brizola, no Rio Grande do Sul, com o Partido Trabalhista Brasileiro (PTB), representando um movimento nacional popular, e do governador Juscelino Kubitschek, em Minas Gerais, assim como o governador Moyses Lupion, no Paraná. Eles carregavam a bandeira do Partido Social Democrático (PSD) da época, fortemente inserida no ambiente de modernização regional, o que leva, inclusive, Kubitschek à presidência da República, apoiado em um discurso comum entre PTB e PSD, o desenvolvimentismo.

Levando em consideração estes transcursos políticos, as empresas, a seu modo, ocuparam um lugar de destaque neste momento. Em primeiro lugar por terem sido as formuladoras dos primeiros planos estaduais de energia nas décadas de 1940 e 1950, inaugurando a prática de planificação do setor, e em segundo lugar por fazerem parte de algum plano de desenvolvimento econômico regional, até então inédito em boa parte do país.

É possível dizer, assim, que o principal causador da reordenação do setor de energia elétrica a nível local foi a assunção de um poder central nacional como regulador a partir de uma organização federal como principal empreendedor, já que todo o sistema foi subordinado ao seu projeto e investimento direto através da Eletrobrás, suas subsidiárias. Ou mesmo, desde empresas estaduais de energia, sob o auspício de instituições públicas de crédito, que por outra parte não deixava de se 
relacionar com as necessidades desenvolvimentistas e modernizadora projetadas a nível regional. Aprofundaremos estas questões consolidação da Espírito Santo Centrais Elétricas S/A (ESCELSA) dentro da estrutura político-industrializante capixaba.

\subsection{Estruturas políticas históricas e a "ameaça" da industrialização capixaba}

Os rebatimentos da política desenvolvimentista nacional implementada na gestão Juscelino Kubistschek (1956 a 1960), na área do investimento público, foram mais fortes nos setores de transportes e energia. Contudo, os ganhos do Espírito Santo não podem ser tidos como relevantes, isso porque a orientação estadual divergiu um pouco do plano nacional, que previa concentração na geração com a construção de grandes usinas hidrelétricas e interligação nacional. Durante o governo Francisco Lacerda de Aguiar (1955 e 1959), foi dada ênfase às pequenas hidroelétricas pulverizadas em diversos municípios do Estado. Tal divergência não impediu que as obras de construção de uma usina hidroelétrica de maior monta, como a de Rio Bonito, tivessem continuidade e o acompanhamento da ESCELSA. E isso se associa ainda ao modo como as elites políticas capixabas vão se relacionar com o projeto desenvolvimentista nacional.

Tudo se inicia na disputa eleitoral capixaba de 1959, que tinha o seguinte quadro de candidatos: representado pela Aliança PSD/PSP, concorreu Carlos Lindenberg (PSD) e Raul Giuberti (PSP); pela Aliança Democrática UDN/PRP, disputou Eurico Rezende (UDN) e Archilau Vivácqua (PRP); e representando o PTB, concorreu com Floriano Lopes Rubim (PTB) ${ }^{144}$ e Arnaldo Pinto de Andrade (PTB).

\footnotetext{
${ }^{144}$ Floriano Lopes Rubim, formado em direito pela Faculdade de Direito da Universidade do Espírito Santo, formou-se também na Escola de Educação Física do Rio de Janeiro (Estado da Guanabara) em 1941. Nesse mesmo ano ingressou na Força Policial do Espírito Santo e participou da campanha militar brasileira na Itália durante a Segunda Guerra Mundial (1939-1945). Em 1948 passou a ajudante-de-ordem na Casa Militar do governador do Espírito Santo, Carlos Lindenberg (1947-1951), função que exerceu até 1949. Em 1950 elegeu-se deputado estadual pelo Espírito Santo, na legenda do Partido Trabalhista Brasileiro (PTB). Em outubro de 1954 elegeu-se deputado federal por seu estado, agora com o apoio da Coligação Democrática formada pelo PTB e pelos partidos Republicano (PR), de Representação Popular (PRP) e Social Progressista (PSP). Encerrou o mandato estadual em janeiro de 1955, assumindo no mês seguinte sua cadeira na Câmara Federal. Se licenciou da Câmara para assumir a Secretaria de Viação e Obras Públicas do Espírito Santo no governo de Francisco Lacerda de Aguiar (1955-1959). Em 1960, participou da campanha de Jânio Quadros para a presidência da República, filiando-se ao Partido Democrata Cristão (PDC). No entanto, no dia seguinte ao pleito realizado em outubro e vencido por Jânio, desligou-se do PDC, filiando-se ao Partido Trabalhista Nacional (PTN). Em outubro de 1962 voltou a se eleger deputado
} 
O candidato da Aliança PSD/PSP, o ex-governador Carlos Fernando Monteiro Lindenberg, era um dos principais líderes políticos do Espírito Santo. Sua trajetória política é o retrato do próprio movimento político realizado pelo Estado do Espírito Santo, pós-Vargas, que busca o pragmatismo e advoga pela necessidade imperiosa de salvar o Estado do caos financeiro e administrativo.

O representante do PTB, Floriano Lopes Rubim, era o primeiro candidato ao Governo do estado cuja origem social não remetia ou era de alguma forma, relacionada às oligarquias agro fundiárias nem às mercantis-exportadoras. Como sua principal plataforma política, estava a criação das condições para a industrialização do Estado, principalmente uma infraestrutura energética.

E por último, o candidato da UDN/PRP, Eurico Vieira de Rezende. Mineiro de origem, filho de aristocracia rural. Sua plataforma propunha as soluções para os problemas do estado de forma genérica.

O resultado desta eleição foi a vitória de Carlos Lindenberg ${ }^{145}$, que em discurso no ato de sua posse, diz:

federal com o apoio da coligação formada pelo PTN e o Partido Social Democrático (PSD). Assumiu o mandato em fevereiro de 1963, tornando-se vice-líder do partido na Câmara em junho do ano seguinte. Com a edição do Ato Institucional n 2 (AI-2), filiou-se à Aliança Renovadora Nacional (Arena), partido de apoio ao regime militar instalado no país após a deposição do presidente João Goulart em 31 de março de 1964. CPDOC (FGV). Dicionário Histórico-Biográfico Brasileiro Online: Floriano Lopes Rubim. Rio de Janeiro, 01 dez. 2020. Disponível em: http://www.fgv.br/cpdoc/acervo/dicionarios/verbete-biografico/floriano-lopes-rubim.

${ }_{145}$ Carlos Fernando Monteiro Lindenberg nasceu em Cachoeiro do Itapemirim (ES). Era sobrinho de Jerônimo de Sousa Monteiro, deputado federal, senador e governador do estado do Espírito Santo de 1908 a 1912; de Bernardino de Sousa Monteiro, vereador, deputado estadual, senador e governador do mesmo estado de 1916 a 1920, e de Fernando Sousa Monteiro, que foi bispo de Vitória. Em 1930 participou, em âmbito estadual, do movimento revolucionário que depôs o presidente Washington Luís, articulando-se com Joaquim de Magalhães Barata, o tenente Pio Borges da Cunha e outros. Lindenberg participa da fundação do Partido Social Democrático (PSD) no Espírito Santo e, nessa legenda, foi eleito deputado constituinte, iniciando seu mandato em 15 de novembro de 1933. Em 1934 deputado federal pelo Espírito Santo, assumiu a Secretaria de Fazenda do estado, a convite do governador João Punaro Bley. Chefiou cumulativamente, a partir de 1936, a Secretaria de Agricultura. Em 1947 concorreu pelo PSD, ao governo do Espírito Santo e foi eleito. Em outubro de 1950 foi eleito senador pelo Espírito Santo na legenda da coligação PSD-Partido Trabalhista Brasileiro (PTB), para o período legislativo 1951-1959. Em 1958 voltou a se eleger governador de seu estado na legenda do PSD. Após 1964, filiou-se à Aliança Renovadora Nacional (Arena), partido de sustentação do regime militar. Em 1966, indicou Cristiano Dias Lopes Filho para o governo do Espírito Santo, nas eleições indiretas estabelecidas pelo AI-3, de 7 de fevereiro de 1966. Aceita a indicação pela Arena capixaba, Cristiano foi eleito pela Assembleia Legislativa em setembro do mesmo ano. Em 1970 indicou para o governo do estado Artur Carlos Gerhardt Santos e, mais uma vez, a Arena ratificou a indicação, sendo seu candidato eleito em novembro. Após deixar a vida política em 1975, dedica-se a diretoria da Companhia Vale do Rio Doce, cargo que ocupava desde o governo de marechal Humberto Castelo Branco (1964-1967) e, posteriormente, a atividades de consultoria. CPDOC (FGV). Dicionário Histórico-Biográfico Brasileiro On-line: Carlos Fernando Monteiro Lindenberg. Rio de Janeiro, 13 dez. 2020. Disponível em: http://www.fgv.br/cpdoc/acervo/dicionarios/verbete-biografico/carlos-fernando-monteirolindenberg. 
"[...] Como é do conhecimento público, o primeiro trabalho, o mais árduo e mais difícil da nova administração será o de reorganizar e de finanças do Estado [...]. O Governo não poderá, porém, ater-se apenas à reorganização administrativa e das finanças públicas. Terá que se empenhar de modo a proporcionar ao Estado, meios de trabalho e de criação de riquezas, que forneçam novas fontes de renda, acompanhando o País, no seu acelerado crescimento. [...] Programa de utilização de nossas fontes de energia elétrica terá prioridade, para aproveitamento de nossas matérias primas e industrialização dos produtos da lavoura, o que redundará na sua valorização e fomento."146

Lindenberg, mesmo se colocando ao lado personalíssimo oligárquico do PSD capixaba, que articulava a manutenção da hegemônica das elites agroexportadora latifundiária ${ }^{147}$, não podia se esquivar das transformações que se processavam de forma acelerada a nível nacional, e que refletiram no Espírito Santo ao longo do seu governo seu Governo, entrecortando o seu projeto de poder político a nível regional. Neste contexto, tenta tomar o controle das mudanças econômicas, evitando rupturas bruscas com a ordem agrária.

Carlos Lindenberg retoma o projeto de desenvolvimento iniciado por Jones dos Santos Neves, mas tentando imprimir feições mais próximas de sua força políticas. Enquanto Jones dos Santos Neves tinha ideias de desenvolvimento industrial acelerado induzido pelo Estado, Lindenberg solidarizava-se com a alternativa mais conservadora, protagonizada pela burguesia agromercantil, cuja base fundamental de interesses era expressa pela economia cafeeira. Seu programa de governo, ainda como candidato dizia:

“[...] Empregaremos todos os esforços possíveis para a realização do
programa de eletrificação propiciando a industrialização do Estado,
visando às nossas fontes de receita e produção a que aludi. Como não
compreendo industrialização sem produção agrícola, entendo que a
agricultura em todos os seus ramos, deverá ter todo o amparo, toda
assistência técnica, social e financeira, como seu mais legitimo direito.
[...] A meu ver a industrialização, em nosso país, está intimamente
ligada ao desenvolvimento agrícola. Precisam caminhar paralelamente.
Qualquer desequilíbrio será fatal, desastroso para a economia nacional
". ${ }^{448}$

Mesmo assim, o seu governo vai concluir as obras da hidrelétrica de Rio Bonito e dar seguimento ao Plano Elétrico Estadual. Nas palavras de Lindemberg: “O programa de utilização de nossas fontes de energia elétrica terá prioridade,

\footnotetext{
${ }^{146}$ Espírito Santo (Estado). Governador, 1959-1962 (Carlos Lindenberg). Mensagem à Assembleia Legislativa, Imprensa Oficial. p. 3. Vitória,1960.

${ }^{147}$ SILVA, 1986.

${ }^{148}$ Jornal A Gazeta, 19/03/58, $1^{\text {a }}$ p., Roteiro (de Governo) do Candidato Carlos Lindenberg.
} 
para o aproveitamento de nossas matérias primas e industrialização dos produtos da lavoura [...]."149

O que nos parece claro é que, ao mesmo tempo que aceita a lógica de modernização nacional, a conduta de Carlos Lindenberg tinha como objetivo manter a estrutura fundiária existente no Espírito Santo, o que garantia a manutenção política das elites constituídas, principalmente aquelas reproduzidas na grande e pequenas propriedades rurais.

E isso tem relação com uma crise persistente na economia cafeeira, que corroía o capital econômico e político de boa parte das elites capixabas, o que, além de tudo, reforçaria o ganho de espaço e maior poder de luta de novas forças. Assim, inicia-se a configuração de um núcleo de elites políticas identificadas com o projeto de industrialização a nível nacional, as quais passaram a buscar formas de inserir o Espírito Santo com mais intensidade neste projeto. Essas forças se agregariam em torno da recém-criada Federação das Indústrias do Espírito Santo (FINDES) ${ }^{150}$.

\subsubsection{O aprofundamento da crise do café e o "consenso" pela industrialização}

A crise da agricultura cafeeira no Espírito Santo é considerada por uma vasta bibliografia, a conhecimento: BUFFON (1992), SILVA (1986), ROCHA \& MORANDI (1991), SIQUEIRA E VILLASCHI (2011), OLIVEIRA (2018) - como marco do momento em que iniciativas políticas fundamentadas no Estado foram direcionadas para o desenvolvimento urbano e industrial no Espírito Santo.

E é ainda entre as décadas de 1940 e 1950 que se chega ao máximo da expansão da cafeicultura em território capixaba, sendo o evento complementar de uma tempestade perfeita, em que conjugam ao mesmo tempo: pragas nos cafezais ${ }^{151}$, o início de um programa nacional de erradicação, e finalmente, novos setores da economia capixaba ganham dinamismo, acelerando a falta de mão de obra. O resultado mais direto disso é, já nos primeiros anos da década de 1960, o declínio derradeiro do cultivo de café ${ }^{152}$.

Além disso, por ser um estado agroexportador onde, em 1960, 56,6\% da arrecadação com exportações vinha do café, e como a características do cultivo se

\footnotetext{
149 Jornal A Gazeta, 01/02/59, p. 01. Capa.

${ }^{150}$ Criada em 1958

${ }^{151}$ Entre as mais conhecidas, a Broca e a Ferrugem.

${ }^{152}$ Mesmo que este nunca deixará de ser referência para a economia capixaba.
} 
relacionavam fortemente com uma produção agrícola familiar e em pequenas propriedades, se viveu uma crise de grandes proporções em vários lugares da sociedade $^{153}$. Entre 1962 e 1967, foram erradicados 53,8\% dos cafeeiros capixabas, gerando a eliminação de 60mil empregos, o que equivaleu a 200 mil pessoas migrando do campo para a cidade. ${ }^{154}$

O cenário levou as elites estaduais afetadas à constatação da necessidade de diversificação profunda da economia, o que Oliveira (2018) chama de consenso de necessidades. Não existia opção para estes grupos, a não ser confluir para um profundo projeto industrializante, gestado por elas próprias - mas ao auspício nacional - e sob o controle do PSD ${ }^{155}$.

Mesmo com a tentativa de manutenção de seus poderes, muitas destas elites agrárias perdem seu espaço dando lugar a forças com um viés urbano-industrial, e outras abraçaram de forma definitiva o ideário desenvolvimentista que se colocava. Nas palavras de Christiano Dias Lopes ${ }^{156}$ :

\begin{abstract}
“[...] A própria estrutura socioeconômica do estado, que se assentava tradicionalmente na lavoura de café, desabou no rasto dessa cultura, sem que nosso incipiente desenvolvimento industrial alcançasse um nível de expressão capaz de oferecer qualquer compensação pelas consequências do radical colapso do cafeeiro. As implicações sociais do desastre outorgam ainda ao governo, a pesada responsabilidade de assistir as populações que estão se desajustando, exatamente no momento em que por consequências do mesmo fenômeno, estão arrasadas as parcas possibilidades tributarias do Estado." 157
\end{abstract}

Por este caminho, foi criado, na Federação das Indústrias do Espírito Santo (FINDES) em 1959, um conselho técnico que teria enorme influência nos governos que se seguiram. O Conselho Técnico foi constituído com os seguintes membros: Eliezer Batista e Arthur Carlos Gerhardt Santos, além de Alberto Stange, Humberto

\footnotetext{
${ }^{153}$ MEDEIROS, Antônio Carlos. Espírito Santo: a industrialização como fator de desautonomia relativa. Dissertação de mestrado (Mestrado em Administração Pública). Escola Brasileiro de Administração Pública da Fundação Getúlio Vargas, Rio de Janeiro, 1997; Arquivo Público do Estado do Espírito Santo. IBC/GERCA, 1979.

${ }^{154}$ Com uma população total estimada de 1.599 .333 , ou seja, uma migração de $12,50 \%$ de sua população. Fonte dos dados: IJSN, 1977.

${ }^{155}$ Partido Social-Democrata (PSD).

${ }^{156}$ Governador entre 1967 e 1971.

${ }^{157}$ ESPÍRITO SANTO, Ano Zero. A Gazeta, Vitória, p. 2, 30 mar. 1967.
} 
Pinheiro Vasconcelos, Aloísio Simões, Jorge Faria Santos e Bolivar de Abreu, e depois Guy Predo de Freitas e Eugênio Pacheco ${ }^{158}$.

O Conselho Técnico da FINDES e posteriormente o Conselho de Desenvolvimento Econômico (CODEC), criado pela Lei estadual № 1.613 , de 10 de fevereiro de 1960, agiram prioritariamente no sentido de produzir o mapeamento da situação do estado, articulando junto à Confederação Nacional das Indústrias (CNI) o apoio ao planejamento para o desenvolvimento do Governo Estadual, realizando assim, em 1960 o "Seminário Pró-Desenvolvimento Econômico do Espírito Santo".

Marta Zorzal e Silva (1986) fazem uma interessante análise sobre a atuação da FINDIS e sobretudo, do CODEC sobre o governo estadual a partir daí:

“[...] o processo de planejamento, enquanto atividade tecnocrática, tem início na nova esfera de agregação e articulação de interesses, e, em sua dinâmica, avança para o interior do Aparelho de Estado produzindo modificações na sua estrutura institucional (SILVA, 1986, p. 240)"

\footnotetext{
${ }^{158}$ Eliezer Batista, engenheiro, que ingressa em 1949 na Companhia Vale do Rio Doce, trabalhando no Departamento de Construções da Estrada de Ferro Vitória-Minas. Ocupou, posteriormente, os cargos de chefe do Departamento da Via Permanente (1951) e de assistente de engenharia (1957). Em maio de 1959, foi nomeado superintendente da estrada. Em 1961, assume a direção da Companhia, em substituição a Francisco de Sá Lessa. Em 1962, foi nomeado ministro das Minas e Energia em substituição a João Mangabeira. Integrava o gabinete provisório chefiado por Hermes Lima (1962-1963). Em abril de 1963, participou da Comissão de Nacionalização das Empresas Concessionárias do Serviço Público (Conesp), para a compra das subsidiárias da Bond and Share, pertencente ao grupo American and Foreign Power Company, e da International Telephone and Telegraph (ITT). Como ministro, foi também presidente do Conselho Nacional de Minas e Energia e da Comissão de Exportação de Materiais Estratégicos. Em 1968, foi designado presidente da fundação da Rio Doce Internacional S/A, subsidiária da Vale com sede em Bruxelas. Na década de 1970, a partir do governo de Rondon Pacheco (1971-1975) em Minas Gerais, passou a atuar também como consultor e promotor de negócios para o governo mineiro, quando várias indústrias de bens de capital se instalaram no estado. Em março de 1979, com o início do governo João Figueiredo, voltou a presidir a Companhia Vale do Rio Doce. CPDOC (FGV). Dicionário Histórico-Biográfico Brasileiro On-line: Eliezer Batista Da Silva. Rio de Janeiro, 04 dez. 2020. Disponível em: http://www.fgv.br/cpdoc/acervo/dicionarios/verbete-biografico/eliezer-batista-da-silva. Sobre Arthur Carlos Gerhardt Santos, Secretário do Planejamento de Viação e Obras Públicas no Espírito Santo de fevereiro de 1966 a janeiro de 1967, durante os governos de Francisco Lacerda de Aguiar (1963-1966) e de Rubens Rangel (1966-1967), também em 1967, diretor-presidente da Companhia de Desenvolvimento Econômico do Espírito Santo (Codes), atual Banco de Desenvolvimento Econômico do Espírito Santo (Bandes). Durante o ano de 1969 exerceu o cargo de diretor-presidente da Associação Brasileira de Bancos de Desenvolvimento (ABDE). Indicado pelo senador, naquele momento, da Aliança Renovadora Nacional (Arena) Carlos Lindemberg, para o cargo de governador do Espírito Santo nas eleições indiretas de outubro de 1970, foi eleito pela Assembleia Legislativa assumindo o governo em 1971 e indo até 1975. CPDOC (FGV). Dicionário Histórico-Biográfico Brasileiro On-line: Arthur Carlos Gerhardt Santos. Rio de Janeiro, 04 dez. 2020. Disponível em: http://www.fgv.br/cpdoc/acervo/dicionarios/verbete-biografico/artur-carlosgerhardt-santos. Para os demais, cabe ressaltar que além de Batista e Santos, Alberto Stange que era Professor, advogado, escritor e político, Humberto Pinheiro Vasconcelos, Coronel do exército e economista, e Bolivar de Abreu era médico sanitarista e foi secretário da educação do governo Carlos Lindenberg e Guy Predo de Freitas, Diretor do jornal A Gazeta.
} 
O governo capixaba foi incorporando em seu núcleo a participação de entidades corporativas que, a começar pelas diretrizes formuladas pelo Conselho Técnico e posteriormente por sua versão estatal, o CODEC, passaram a elaborar de forma constante um projeto de industrialização voltado à exportação, baseado fundamentalmente na indústria de base, logística industrial e agroindústrias.

Cabe registrar a articulação das elites políticas do Espírito Santo para a transferência da sede da CVRD do Rio de Janeiro para Vitória, e ainda para que um representante do Espírito Santo fosse indicado para a Presidência da Companhia, no caso, Eliezer Batista. Com a transferência da sede e a administração de Batista, a Empresa passa a investir mais intensamente no Espírito Santo, em direção à criação de condições para a instalação da indústria siderúrgica acoplada ao Porto de Tubarão, na parte continental do município de Vitória, que se chamaria Companhia Siderúrgica de Tubarão (CST) ${ }^{159}$, e que seria criada em 1976.

Na comemoração do segundo aniversário da Rádio Espírito Santo em 1961, o Governador Lindenberg enfatiza que o Espírito Santo despertava e caminhava para eliminar os entraves que dificultavam a expansão econômica do Estado no campo industrial. O primeiro passo para isso, foi a assinatura em 1962 do contrato entre Governo Estadual e Federal para a construção do Porto de Tubarão. O que posteriormente faria parte das metas prioritárias do Governo Federal.

3.3.2 O sistema elétrico capixaba como parte do mecanismo políticoindustrializante

Com a transferência da sede da CVRD para Vitória, também se dá a ampliação da estrada de ferro Vitória-Minas, o melhoramento no porto de Vitória e construção do Porto de Tubarão - como já dissemos -, que ocorre entre 1963 e 1964. Neste mesmo momento, a Companhia de Ferro e Aço de Vitória (COFAVI) amplia sua produção, inaugurando em 1963 seu alto forno a carvão vegetal para produção de ferro-gusa ${ }^{160}$. Em todos os casos, empreendimentos eletrointensivos que fizeram crescer a pressão para a construção de novas fontes geradoras de energia elétrica no Estado, fomentando o debate sobre a ausência de investimentos da CCBFE em usinas hidrelétricas.

\footnotetext{
${ }^{159}$ Hoje, ArcelorMittal Tubarão.

${ }^{160} \mathrm{O}$ ferro-gusa é uma liga de ferro, resultado da redução do minério de ferro ao absorver carbono em um alto-forno.
} 
A entrada em funcionamento da usina de Rio Bonito em 1959 - que representou um acréscimo de $70 \%$ na capacidade instalada de energia no estado -, trouxe um alento ao sistema elétrico capixaba. Contudo, os conflitos entre governo do estado, sociedade e CCBFE continuaram fortes.

A entrada da ESCELSA na produção de energia indicava para as camadas dirigentes e para a população a possibilidade de a empresa estadual atuar também na distribuição e pôr fim a existência da CCBFE como concessionária. No mesmo tempo, o movimento de encampação da CCBFE, liderado pelo Gen. José Patente Frota, organizava piquetes ao redor do posto arrecadador da CCBFE, no centro da capital, para impedir o pagamento de contas de energia à empresa. Se juntaram à campanha contra a CCBFE deputados, sindicalistas, o arcebispo de Vitória, empresas e indústrias, entre elas a Chocolates Garoto S/A, uma das maiores produtoras de chocolate do país, que ameaçava se mudar para São Paulo.

Em 1961, o governo do estado recebe autorização para capitalizar a ESCELSA, vendendo $49 \%$ de suas ações, a fim de atrair novos recursos e viabilizar as obras da Usina de Suíça. Além disso, foi autorizado pelo poder legislativo estadual que a CVRD se tornasse sócia da Escelsa pela compra das ações, dando substancial ajuda à execução do programa de eletrificação no Espírito Santo. O que, ao mesmo tempo, significava o início da entrada de capital federal na empresa estadual de energia, aprofundando-se ainda mais com a participação do BNDE no negócio.

Para a participação do Banco, o governo do estado teria que criar projetos para a construção das usinas de Timbui e Santa Leopoldina, além do exame operativo das unidades de Rio Bonito e Suíça e da implantação de outras usinas térmicas. É importante dizer que este acordo entre BNDE e Governo do estado do Espírito Santo, muito além de uma iniciativa para ampliar o abastecimento de energia elétrica em território capixaba, também estava relacionado com a participação do banco na administração da empresa, através da cláusula BNDE/ESCELSA FFE-10 que previa a indicação, pelo banco, de três membros do conselho fiscal da empresa. Assim, mesmo sendo o retrato de uma política estadual de fomento às indústrias, foi também uma forma de subordinação definitiva aos interesses e necessidades do governo federal dentro do setor elétrico regional.

A importância do setor elétrico para a política capixaba neste momento também vai se expressar pela ascensão ao governo do estado, de forma indireta, de 
Asdrúbal Soares, que tinha sido o primeiro diretor da Espírito Santo Centrais Elétricas S/A. Aliado do PSD, era um dos dirigentes do PSP, um dos poucos quadros a participar do governo Lindenberg. Historicamente, Soares sempre se relacionou com a organização dos serviços de energia elétrica no Espírito Santo. Ao mesmo tempo, sempre esteve bem relacionado no campo político, junto às forças que estiveram no poder.

A subida de Asdrúbal Soares a secretaria de obras públicas em 1958, e a posterior ocupação do cargo de diretor da ESCELSA a partir de 1960, sem dúvida o colocou como candidato à ocupação do governo do estado de forma interina entre 1962 e $1963^{161}$. Dentro deste quadro, Soares se torna, mesmo que por um breve período, um dos maiores articuladores no processo de encampação da CCBFE.

E foi ainda em 1962 que aconteceu a primeira tentativa de encampação da CCBFE, através do Decreto Estadual no 302/62. Contudo, após intensa batalha judicial no Superior Tribunal de Justiça Federal (STF), a encampação estadual é julgada ilegal, sob a alegação do estado estar interferindo em um serviço público federal.

Este será um dos principais assuntos da corrida eleitoral de 1962. Mas esta derrota na esfera jurídica federal não representava uma derrota na esfera política, já que a frente política vencedora da eleição para governador será a da situação, liderada por Francisco Lacerda de Aguiar (PSD) ${ }^{162}$.

Com o sucesso do pleito, o PSD capixaba inicia articulações junto ao governo federal, comandado pelo primeiro-ministro Tancredo Neves (PSD) do governo João Goulart (PTB), para encampação da CCBFE através da compra de todo o grupo AMFORP pela União.

É relevante destacar a proximidade, para além da questão da encampação da CCBFE, existente entre Francisco Lacerda de Aguiar e o governo João Goulart, o que ajudava Aguiar a direcionar a política de desenvolvimento econômico estadual. Assim, o ambiente político nacional conferia ao novo governo estadual um maior

\footnotetext{
${ }^{161}$ Asdrúbal Soares vai ser eleito indiretamente pela Assembleia Legislativa do estado e governou por um breve período, entre agosto de 1962 e janeiro de 1963. Ele ocupa o cargo após a renúncia do governador, vice-governador e do presidente da assembleia para a disputa da eleição de 1962.

162 Importante destacar o quadro da disputa eleitoral da eleição capixaba de 1962. Novamente, haveria um conjunto das forças representado pelas oligarquias agro fundiárias, mas agora com a presença de um núcleo relacionado ao processo de industrialização, orbitando em torno do PSD, contra todos os outros setores relacionados às classes populares urbanas, pequena produção rural, oligarquias mercantis-exportadoras, diluídos nos demais partidos.
} 
respaldo para propor medidas no sentido de atender realmente aos interesses das novas forças políticas na direção que orbitavam a gestão do PSD. Foram elaborados, neste ínterim, o Plano de Industrialização Rural ${ }^{163}$ e o Plano Educacional de Emergência.

A atuação Governo do estado do Espírito Santo também foi beneficiada por uma política de investimento em infraestrutura iniciada pelo governo federal, com a Companhia Ferro e Aço de Vitória (COFAVI) recebendo injeção de capital da ordem de elevado de 3,7 bilhões de cruzeiros através de subscrições feitas pelo BNDE. Sendo assim, o banco era detentor de 95\% do total do capital da Empresa, enquanto está aumentava sua capacidade de produção com a construção da Usina de Laminação do Ferro.

A modernização do estado capixaba parecia se tornar inevitável. E na medida que as elites capixabas relacionadas à inserção do Espírito Santo no processo desenvolvimentista nacional ganhavam mais força, estas passaram a exigir uma maior adaptação da administração estatal.

\footnotetext{
${ }^{163}$ A primeira etapa do Plano de Industrialização Rural foi implementada durante o ano de 1964. Para tanto, o Governo adquiriu 10 fábricas para industrialização de farinha, fécula e raspa de mandioca, 5 fábricas para industrialização do milho e 2 usinas de Laticínios, ao custo total de $\mathrm{Cr} \$$ 400.000.000,00. Estas foram alienadas a 17 cooperativas, "mediante contrato de utilização condicional, até a liquidação do preço ajustado", pelas respectivas cooperativas, conforme o disposto no art. $1^{\circ}$ da Lei 2.069 , de 23/11/64, que autorizou a realização dos contratos.
} 


\section{CAPÍTULO 4 - A LÓGICA CENTRALIZADORA ENTRE 1964 E 1989}

\subsection{O leviatã verde-oliva: os fundamentos da administração estatal do regime militar na construção de um sistema elétrico nacional.}

No capítulo que se inicia, avançaremos na análise dos impactos das transformações do Estado brasileiro durante seu processo de modernização, na organização do sistema elétrico do estado do Espírito Santo. A importância do período de 1964 a 1989 se dá pela centralização nacional do projeto de desenvolvimento econômico, o que repercutiu na forma de articulação das elites locais buscando a manutenção de sua participação nos caminhos tomados pelo setor elétrico regional.

Importante dizer que, a crise político-institucional que deu origem ao golpe de 1964, teve uma importância significativa para a implantação de reformas no setor elétrico que por um lado, incorporaram o sentido autoritário resultante do movimento militar e, por outro, atenderam a necessidade de reorganização do investimento público, de modo a adequá-lo ao estágio alcançado pela economia brasileira. Assim, a legislação e a dinâmica institucional deixaram de expressar a ordenação das relações entre o poder público e o setor privado, e passaram a desenvolver-se sob a órbita do Estado e da empresa pública federal.

Nos primeiros tempos após o levante militar, foi no Instituto de Pesquisas e Estudos Sociais (IPES) que se articulou a transformação de golpe em governo. Os alvos prioritários eram a ocupação de cargos na estrutura de planejamento governamental por parte dos apoiadores do golpe, civis e militares. Além disso, se buscava a definição de política econômica com o estabelecimento do Ministério do Planejamento e Coordenação Econômica.

\footnotetext{
“moldado através da colaboração ativa entre militares e setores civis interessados em implantar um projeto de modernização impulsionado pela industrialização e pelo crescimento econômico, e sustentado por um formato abertamente ditatorial. A interferência na estrutura do Estado foi profunda. Exigiu a configuração de um arcabouço jurídico, a implantação de um modelo de desenvolvimento econômico, a montagem de um aparato de informação e repressão política, e a utilização da censura como ferramenta de desmobilização e supressão do dissenso" (SCHWARTZ e STARLING, 2015 p. 449).”
}

O novo regime utilizou o desempenho econômico como critério básico de legitimidade, entrando em cena a ideia de eficiência empresarial, dando às instituições econômicas ascendência com relação às outras instituições públicas 
nacionais ${ }^{164}$

No caminho dos novos instrumentos de política econômica, deu-se início ao Plano de Ação Econômica do Governo (PAEG), executado durante o período de 1964-1966. Esse plano tinha como principais objetivos acelerar o desenvolvimento econômico e incluir, entre outras coisas, a expansão das empresas públicas federais.

O Estado ditatorial militar, assim, buscava expandir suas intervenções na vida econômica e social, além de descentralizar as atividades do setor público, criando órgãos da "administração indireta"165, implicando em uma maior autonomia e delegação de autoridade.

Como reflexo desta busca por autonomia, foi publicado o Decreto-Lei $\mathrm{n}^{\circ}$ 200 de 1967, que marcou a implementação da uma segunda reforma administrativa $^{166}$. Esse decreto inseriu a descentralização na prestação de serviços públicos, levando às transferências de atividades que eram realizadas pela administração direta do executivo para as autarquias, fundações, empresas públicas e sociedades de economia mista. Este decreto pode ser compreendido também como o aprofundamento de um modelo de administração pública gerencial.

No governo do gen. Costa e Silva (1967 a 1969) é criado o Programa Estratégico de Desenvolvimento (PED), que ficou responsável por apontar a necessidade de um crescimento ordenado, essencialmente na indústria de bens de produção e de bens de capital. Foi o momento inicial de uma mudança no modelo normativo da política industrial entre os anos 1970 e aos anos 1980. Reconheceuse, assim, o fim da substituição de importações como processo de industrialização e foram criadas metas mais qualitativas para inovação e desenvolvimento tecnológico, qualidade e produtividade.

A modernização e a racionalização das instituições administrativas em âmbito nacional compuseram parte importante do receituário empregado pelo governo militar para o relançamento do país em uma nova etapa do desenvolvimento capitalista, no qual, aprofunda-se o processo de industrialização

\footnotetext{
${ }^{164}$ RAPOSO, 2011, p. 94.

165 Autarquias, fundações públicas, empresas públicas e sociedades de economia mista. São entidades administrativas autônomas, criadas por lei específica, com patrimônio próprio e atribuiçõos estatais específicas.

166 Para Capobiango (2010), a primeira reforma administrativa ficou conhecida como Reforma Burocrática de 1936, tendo como característica a ênfase na reforma nas atividades de administração geral, montando um corpo burocrático clássico, de funcionários do Estado, não contemplando, porém, as atividades substantivas. Pautou-se na teoria administrativa que consagrava a existência de "princípios de administração", adotando a modernização da máquina pública como norte central.
} 
baseado no chamado modelo do tripé: empresa nacional, empresa estrangeira e um forte setor estatal ${ }^{167}$.

O ex-ministro do Ministro de Minas e Energia, entre 1964 e 1967, Mauro Thibau, em entrevista ao Centro de Memória da Eletricidade em 1997, faz uma análise a respeito do relacionamento entre o setor elétrico e o momento de mudança na administração pública. Ele aponta que havia a necessidade de se definir uma doutrina política para o setor, no sentido de resguardar a iniciativa privada dentro das reformas propostas pelo governo federal, ou mesmo de criar uma empresa brasileira semelhante à Electricité de France ${ }^{168}$. Thibau, afirma que chegou a pensar em centralizar toda a geração e transmissão na Eletrobrás, "que seria a única entidade capaz de assegurar autoridade e responsabilidade permanentes" (MEMORIA DA ELETRICIDADE, 1997, p. 174).

Tanto nos esforços de aprofundamento de um modelo de administração gerencial quanto no sentido de aprofundar o planejamento do desenvolvimento econômico estatal, é possível dizer que o setor elétrico foi o de maior atuação do regime militar. E a consolidação da Eletrobrás, talvez tenha sido a maior amostra disso.

Como resultado, tem início um novo período na história do setor elétrico, com apoio integral tanto político quanto econômico da União. Uma das primeiras ações neste momento foi a criação de uma correção monetária que possibilitou a retificação dos ativos das empresas. Também foi reajustado o valor da tarifa de energia elétrica, fazendo crescer o volume de recursos financeiros disponíveis para investimento do setor.

Este período também é marcado pela nacionalização da American \& Foreign Power Company (AMFORP) em 1964 e a sequente partilha de suas 10 subsidiárias entre as empresas estaduais de energia até o ano de 1968, o que levou ao fortalecimento destas empresas regionais. Nas palavras de Mauro Thibau, “ocorria o que John Cotrim denominou de 'cemiguite', ou seja, em face do êxito da CEMIG, cada estado queria ter sua empresa de energia elétrica" ${ }^{\text {"169. }}$

Em 1967 é criado o Sistema Nacional de Eletrificação, sob o comando da

\footnotetext{
167 DINIZ, 2010.

${ }^{168}$ Empresa estatal francesa responsável pela geração, transmissão e distribuição de energia elétrica na França.

${ }^{169}$ Memória da Eletricidade. Mauro Thibau: A trajetória de um ministro. Centro de memória da Eletricidade no Brasil, 1997 p.173.
} 
Eletrobrás. Vai definindo-se, assim, a disposição governamental de transformar as empresas estaduais em instituições com capacidade financeira e técnica para interligar as zonas econômicas locais, processo que foi concluído apenas em 1979, com a compra da Light e o encerrando da participação dela e da AMFORP no setor elétrico nacional, passando, então, as empresas subsidiárias das empresas para o controle de seus respectivos governos estaduais.

Em 1968 é criada a Eletrosul, e em 1973 a Eletronorte, como geradoras de energia a nível regional. Já em 1973 foi criada a Itaipu Binacional, passando o controle da hidrelétrica e de outras empresas para Eletrobrás, além de consolidar o papel das empresas como agência de planejamento, financiamento e holding federal no setor elétrico, atuando em todo o território nacional.

A Usina Hidrelétrica de Tucuruí também se coloca como grande projeto federal deste período. Seu planejamento foi feito dentro da Eletrobrás através do Plano de Expansão para as Regiões Sul e Sudeste até 1990 - ou Plano 90 -, levando em consideração um ritmo de crescimento do consumo de energia elétrica superior a $12 \%$ a.a. no período de $1975-1980$ e em torno de $10 \%$ a.a. no período de $1980-$ 1990.

O Plano 90 foi o primeiro plano a estudar de forma global os sistemas elétricos interligados no Brasil. A ideia era adequar a capacidade instalada de energia ao crescimento projetado econômico do país. Estas projeções sinalizaram para uma expansão da capacidade instalada da ordem de 30.000 MW até o final de 1980. Importante destacar, também, que em 1974 o Brasil possuía 17.500 MW.

\footnotetext{
"além da construção da Usina de Itaipu, o plano previa a implantação de usinas de grande porte, com destaque para Tucuruí (4.000 MW), no Rio Tocantins, primeiro grande empreendimento da região amazônica; Itaparica (2.500 MW), Sobradinho (1.050 MW) e Paulo Afonso IV (2.500 MW), todas no Rio São Francisco; Itumbiara (2.100 MW), Emborcação (1.000 MW) e Porto Primavera (1.800 MW) na região Sudeste; Salto Santiago (2.000 MW), Foz de Areia (2.500 MW) e Ilha Grande (2.000 MW) na região Sul” (LANDI, 2006, p. 55).
}

A partir deste cenário, o Ministério das Minas e Energia (MME), o Comitê de distribuição da Região Sul-Sudeste (CODI) e o Comitê Coordenador de Operações do Norte/Nordeste (CCON), como consequência dos resultados alcançados pelas ações dos Grupos Coordenadores para Operações Interligadas (GCOI), conduzem a interligação elétrica brasileira, além dos limites das regiões 
Sudeste e Sul, e promovem a evolução deste modelo dentro das zonas de distribuição de energia ${ }^{170}$.

Ao final de 1979, todo o processo de institucionalização já havia sido concluído. As principais organizações, como a Eletrobrás e empresas por ela controladas, bem como as empresas de energia elétrica estaduais e os diversos fornecedores de bens e serviços já estavam estabelecidos, levando a um aumento da capacidade instalada de energia elétrica, entre 1962 e 1979 de 388,22\% (CMEB, 1995 p.144).

A Eletrobrás teve um papel preponderante também nas iniciativas adotadas e nos suportes técnico, material e financeiro dado às empresas concessionárias que compunham o sistema elétrico brasileiro. Sua presença foi marcante em todas as regiões do país.

A estrutura existente desde a década de 1970, com a implementação de um sistema de transmissão rigidamente interligado em todas as regiões do país, criou as bases para as tendências do sistema elétrico público e privado atual. José Marcondes Brito de Carvalho ${ }^{171}$ em entrevista comenta um pouco sobre a complexidade e o nível de planejamento que o sistema elétrico havia chegado:

[...] O crescimento do sistema elétrico brasileiro, as interligações entre empresas estaduais e federais - em tensão cada vez mais elevada - a construção de aproveitamentos hidrelétricos na mesma bacia - mas pertencentes a empresas diferentes - e a entrada em operação da hidrelétrica de Itaipu associaram o sistema de corrente contínua e alternada. A crescente complexidade dos problemas inerentes ao planejamento e programação da operação impôs também a necessidade de coordenação da operação em tempo real. A Eletrobrás, justamente com as empresas controladoras de área - isto é, as empresas cuja capacidade significativa de geração permitem controlar seus próprios intercâmbios -, desenvolveu o próprio Sistema Nacional de Coordenação da Operação Interligada - Sinc. O Sinc compreende o Centro de Supervisão e Coordenação da Eletrobrás - CSC -, em Brasília, e a modernização ou construção do Centro de Operações do Sistema - o COS - da CEEE, Copel, Cesp, Cemig, Eletropaulo, Light, Furnas, Eletrosul, Eletronorte e Chesf. Para Viabilizar a implementação do projeto Sinsc, foi assinado, em 29 de agosto de 1979, um convenio entre Eletrobrás e as empresas mencionadas. [...] O projeto Sinc, deve ser considerado como parte integrante do sistema eletrico-energetico brasileiro, como instrumento de melhora de gestão

\footnotetext{
${ }^{170}$ Para um amplo panorama do processo de construção do setor acessar Memória da eletricidade. Ver mais em Caminhos da Modernização: cronologia da Energia Elétrica no Brasil (1879-2007). Centro de Memória da Eletricidade no Brasil. Rio de Janeiro, 2007.

${ }^{171}$ Foi chefe da área de Operações das Usinas Elétricas do Paranapanema (USELPA), Diretor da Eletrobrás e da Cesp, reconhecido como criador dos sistemas integrados de transmissão no Brasil. Além disso, foi membro do Conselho Consultivo da Eletrobrás.
} 
desse sistema (MEMORIA DA ELETRICIDADE, 1995, p. 209, 210 e 213).

Mas um outro lado desta história é que, a partir do final da década de 1970, os instrumentos das políticas que antes serviam à instrumentalização do setor elétrico e da industrialização nacional, passaram a ser administrados de acordo com os objetivos da estabilização macroeconômica. As altas taxas de crescimento da economia, as várias obras ligadas a projetos de desenvolvimento regionais, a concentração de renda e o regime político fechado avançaram sobre o país, aprofundando as contradições sociais e a dinâmica política ${ }^{172}$. Dinâmica esta que fica registrada na fala do ex-Ministro da Indústria e Comércio Exterior do regime militar entre 1979 e 1984 e ex-presidente da CEMIG e de FURNAS, Jose Camilo Pena:

\begin{abstract}
"A grande dificuldade que Furnas viveu no plano das realizações foi o fim dos governos estaduais biônicos. Esses governos tinham certa coerência com o governo federal. Com a democracia e a eleição dos governadores por voto direto a estabilidade do sistema federal de energia elétrica e de Furnas passou a ser seriamente contestada e mesmo ameaçada. Vejo graves dificuldades de o sistema estatal sobreviver na democracia. O sistema estadual cresceu e teve sucesso nos regimes militares fechados" (Idem, 1995, p. 243).
\end{abstract}

Para complicar o cenário, o esforço da administração pública na sustentação do crescimento da economia foi praticamente isolado. O capital privado nacional não investiu mais que do que era pedido e o capital privado estrangeiro era escasso, já que boa parte dos países do capitalismo central estavam em crise.

Até fins dos anos 1980, restrições por parte da política econômica fecharam o acesso a importações. Além disso, exportações foram subsidiadas, investimentos públicos em infraestrutura foram reduzidos, orçamentos públicos para financiamento industrial foram drasticamente cortados, incentivos de fomento também foram reduzidos e os controles de preços e tarifas públicas ficaram mais apertados. E com o primeiro e segundo choque do petróleo ${ }^{173}$ e a crise financeira internacional, é configurado um cenário de extrema dificuldade, tanto no setor interno como externo. O setor de energia elétrica foi obrigado, então, a viver sob todas essas restrições e constrangimentos de ordem econômico-financeira ${ }^{174}$.

\footnotetext{
172 RAPOSO, 2011.

173 Que se inicia em 1979.

174 LIMA, 1995.
} 
Ao final da década de 1980, o setor de energia elétrica chegaria à situação de quase insolvência e ingovernabilidade. Curiosamente, é também o período em que suas estruturas institucionais do setor estavam enraizadas como nunca nas próprias estruturas constitutivas do Estado nacional brasileiro.

\subsection{Uma modernização a partir do nacional e os interesses no desenvolvimento do setor elétrico capixaba.}

O golpe militar que se abate sobre o Brasil em $1^{\circ}$ de abril de 1964, não encontrou grande resistência no Espírito Santo. Boa parte das forças políticas do Espírito Santo, incluindo a quase totalidade do PSD e dos partidos que estavam relacionados à Coligação Democrática, apoiaram direta ou indiretamente o golpe militar, tais como: Jones dos Santos Neves (PSD), Carlos Lindenberg (PSD), João Calmon (PSD), João Parente Frota (PSD), Christiano Dias Lopes Filho (PSD), Raul Gilberti (PSP), Asdrúbal Soares (PSP), Eurico Resende (UDN), Floriano Rubin (PTB) e Isaac Rubin (PTB).

Isso porque, naquelas circunstâncias, o cálculo político para não se perder o mandato ou o cargo, era apoiar o Golpe de Estado. Sem falar, que mesmo em um contexto nacional de grande turbulência, os principais jornais do Espírito Santo estavam longe das tensões e da histeria dos noticiários dos outros estados da região Sudeste. Os jornais capixabas enquanto veículos oficiais das principais elites e grupos políticos locais mostravam que no Espírito Santo existiam outros interesses mais urgentes ${ }^{175}$.

Boa parte do ano de 1964, como exemplo, foi marcado pelo auge da campanha pela encampação da Companhia Central Brasileira de Força Elétrica (CCBFE). A campanha tem como um dos protagonistas centrais o Gen. José Parente Frota, na época, também Deputado Estadual pelo PSD.

Uma parte das elites capixabas, incluindo Frota, viam a possibilidade de encampação parecida com a que havia ocorrido no Governo Leonel Brizola (19591962) no Rio Grande do Sul, porém, bastante criticada pela direita, e o processo pelo qual Frota expressava profunda repulsa: "para não deixar o movimento cair nas mãos de comunistas" 176 .

${ }^{175}$ OLIVEIRA, 2018.

${ }^{176}$ OLIVEIRA, 2018, p. 66. 
Contudo, a situação política nacional se deteriorava e a negociação com o governo estadunidense para a compra das empresas do grupo ANFORP acabou sofrendo com essa situação, dando início a um imbróglio nacional com debates acalorados sobre a nacionalização das empresas.

Um debate de grande repercussão e que teve influência em todo cenário de encampações nacional, foi aquele entre o governador do estado do Rio Grande do Sul, Leonel Brizola ${ }^{177}$ e o economista, ex-presidente do BNDE, Roberto Campos, sobre o modelo a ser adotado na estatização das companhias de energia.

Mas a intensão declarada do governo militar era equacionar o problema da nacionalização das empresas multinacionais dos Estados Unidos da América de forma a evitar que o Brasil viesse a prejudicar-se no plano das relações internacionais $^{178}$. O governo federal entendia que não poderia apenas resolver os casos pendentes com o país da América do Norte, com medidas iguais às tomadas em âmbito estadual, como o que havia ocorrido com a concessionária de Porto Alegre. Assim, que em julho de 1964, foi criada uma comissão para tratar do tema que envolvia Eletrobrás, Ministério das Minas e Energia, Ministério da Fazenda, Ministério do Planejamento, Ministério das Relações Exteriores e Ministério Extraordinário para Planejamento e Coordenação Econômica. Em 18 de agosto de 1964 tais grupos entregavam um relatório ao presidente Castelo Branco, apontando que o Brasil deveria firmar acordo para a compra da AMFORP. O contrato de compra da empresa pela Eletrobrás fora, então, assinado em 14 de novembro de $1964^{179}$.

Além de todo esse quadro diplomático, político e econômico, o ponto a favor da estatização do grupo AMFORP pela Eletrobrás é que esta obedecia a um critério de integração entre empresas de energia elétrica inter-regionais que vinha sendo discutido desde o Conselho de Desenvolvimento, ainda do Governo de Juscelino Kubitschek. Desta forma, quando a CCBFE foi adquirida pela Eletrobrás, a unificação dos sistemas das duas maiores concessionárias do Espírito Santo era um passo inevitável, não apenas porque a interligação de sistemas em empresas

\footnotetext{
${ }^{177}$ Que havia nacionalizado a Companhia Estadual de Energia Elétrica (CEEE), já abordado por esta pesquisa no capítulo anterior.

${ }^{178}$ RIBEIRO, 2013.

179 CENTRO DE MEMÓRIA DA ELETRICIDADE NO BRASIL. Políticas de governo e desenvolvimento do setor de energia elétrica. Do código de Águas à crise dos anos 80 (1934-1984). Rio de Janeiro: 1995, p. 188.
} 
regionais já estava prevista na legislação, mas porque, juntos, BNDE e Eletrobrás já detinham o controle acionário do capital com direito a voto da ESCELSA.

O contexto da possibilidade de encampação CCBFE já havia chegado às ruas capixabas e o boicote à empresa por meio do não pagamento da conta de luz quase havia levado a uma greve no setor. O principal jornal do Espírito Santo, $A$ Gazeta, comandado pelo ex-governador Carlos Fernando Monteiro Lindenberg (PSD), trazia matérias e palavras de ordem em favor da encampação.

A nacionalização do setor elétrico começa em âmbito regional em 1964, com a aquisição pela Eletrobrás de todas as empresas do grupo AMFORP, como um dos seus pontos altos ${ }^{180}$. As empresas que pertenciam à AMFORP e atuavam no âmbito regional passaram para o controle de seus respectivos governos estaduais, reforçando sua importância como atores de mudança locais.

Após passar para o controle da Eletrobrás, a subsidiária capixaba da ANFORP, CCBFE, ajustou-se para produzir maior quantidade de energia e satisfazer o aumento progressivo da carga prevista para ocorrer em seu sistema, a começar por 1966 - quando entrariam em operação o porto de embarque de minério de ferro da CVRD (Porto de Tubarão) -, que significaria sair naquele momento de $66.918 \mathrm{~kW}$ para $170.900 \mathrm{~kW}$ no ano de 1975.

O segundo governo Francisco Lacerda de Aguiar (1963 e 1966), estava à frente de boa parte destes projetos. Ele não foi impactado inicialmente pelo golpe militar de 1964, tendo maior parte de seu programa governamental implementado. Foi só à medida que o regime militar tomava corpo e direção, sendo reorientado os rumos políticos e econômicos país, que seu governo foi desestabilizado. Este momento de desestabilização ocorreu quando as forças políticas regionais, principalmente aquelas agregadas em torno do PSD, mesmo partido de Aguiar, articularam em nome do golpe militar meios para tirar Francisco Lacerda de Aguiar da direção do Governo.

A mídia local teve grande participação neste quadro. O Jornal A Gazeta vincula em 1965 denúncias sobre o Governo Lacerda de Aguiar, em torno do envolvimento dele em processos de corrupção administrativa e insinuações a

\footnotetext{
${ }^{180}$ Processo concluído apenas em 1979, com a compra da Light, encerrando a participação dessas
} duas empresas estrangeiras no setor elétrico nacional. 
respeito de possíveis ligações de Francisco Lacerda de Aguiar com elementos subversivos ${ }^{181}$.

Este imbróglio tem como desfecho a renúncia de Francisco Lacerda de Aguiar (PSD) em 1966 e a posse do primeiro governador biônico da ditadura no Espírito Santo, do quadro do antigo PSD, Christiano Dias Lopes (1967-1971). Vencedor do primeiro pleito indireto, Dias Lopes acentuou os objetivos desenvolvimentistas como principal política pública, impulsionando as relações com o planejamento econômico nacional. Dentro disso, colocou em voga o plano de construção, junto à Companhia Vale do Rio Doce, de uma usina de pelotização ${ }^{182}$, além de uma siderúrgica atrelada ao porto de Tubarão. Importante ver o discurso de Christiano Dias Lopes na assembleia legislativa estadual, quando da tomada de posse como governador:

[...] sem dúvida, construção, pela Companhia Vale do Rio Doce, dos terminais de minério e carvão do Porto de Tubarão e a montagem de Usina de "Pellets", possibilitando à empresa uma política agressiva de exportação de minérios; o Projeto de uma Usina Siderúrgica Integrada por que vem lutando a Companhia de Ferro e Aço a ser construída em área de que é proprietária em Ponta de Tubarão, os auspiciosos projetos do Grupo Antunes já aprovados pelo governo federal que vão desde os entendimentos com a Vale do Rio Doce para a exportação de minério do Vale do Paraopeba através do Porto de Tubarão, até a construção de uma Usina de Pelotização e uma siderúrgica, criam perspectivas extraordinárias para um grande complexo industrial na Região de Vitória". ${ }^{183}$

$\mathrm{Na}$ questão da racionalidade administrativa, dentro da necessidade latente de modernização estatal sob a lógica desenvolvimentista, o governo Dias Lopes tendo como base o Decreto-Lei 200 de fevereiro de 1967 sobre reforma administrativa na esfera federal e a Lei Estadual n 2296/67xii sua regulação similar no plano local - promoveu uma reformulação do setor público estadual cuja lógica visava a implementação de políticas respaldadas pelo eixo da tecnocracia.

\footnotetext{
181 O pronunciamento de Francisco Lacerda de Aguiar sobre sua renúncia é interessante para entender o que acontecia: [...] chegou um coronel e me disse: - 'Eu vim aqui lhe aconselhar a deixar o Governo. 'O senhor está atrapalhando a Revolução'. E eu: - 'Mas estou atrapalhando a Revolução por quê'? E ele: - 'O senhor está atrapalhando a revolução por uma razão muito simples, o senhor é muito ligado ao povo. E homens como senhor, Carlos Lacerda, Ademar de Barros, Arraes e Juscelino, não podem continuar atrapalhando a Revolução'. De fato, logo depois que saí eles saíram [...] (SILVA, 1986, p. 435).

${ }^{182}$ A pelotização é o processo de compressão ou moldagem do mineiro de ferro na forma de um pellet.

${ }^{183}$ ESPÍRITO SANTO (ESTADO). Estado do Espírito Santo tem um novo governador: discurso. 1967.
} 
Edmilson Felipe et al. (2010) apontam que algumas das principais ações nesse sentido foram: a revitalização do Conselho de Desenvolvimento Econômico (CODEC), que a partir de 1967 fica também responsável pela elaboração e controle do orçamento estadual, e a criação da Companhia de Desenvolvimento Econômico do Espírito Santo - CODES.

Quem assumiria o CODES seria Arthur Carlos Gerhardt Santos que havia sido Secretário de Viação e Obras Públicas no governo transitório de Rubens Rangel ${ }^{184}$. Ele era aliado de Dias Lopes e se tornaria o segundo governador eleito indiretamente do estado, entre 1971 e 1975.

Neste momento, a participação do governo federal no contexto de desenvolvimento do estado fica ainda mais nítida. O papel da Eletrobrás na reestrutura do setor elétrico capixaba vai se aprofundando a partir do decreto 57.927 de 19 de novembro de 1965, que atribui competências para participação de cada empresa concessionária regional, sujeitando as novas concessões ao cumprimento de pré-condições básicas, tais como a inclusão do projeto no programa de obras prioritárias do Comité centro-sul, a capacidade de absorção pelo sistema de concessionárias de energia a ser gerada e a sua capacidade de obter financiamento.

Posteriormente, o decreto 60.824, de 07 de junho de 1967, definiu melhor as competências de DNAEE (Departamento Nacional de Águas e Energia Elétrica) como órgão concessor, enquanto à Eletrobras caberia a operação dos sistemas empresariais do setor elétrico, aprofundando a tendência de absorção e fusão ao recomendar a conveniência de concentração em número limitado de empresas de eletricidade e providenciando a integração destas empresas.

Paralela a esta questão, em decorrência da ausência de políticas de desenvolvimento nacionalmente integradas na época, via-se a possibilidade de fusão da ESCELSA/CCBFE como uma oportunidade de obter recursos públicos para o estado visando outros projetos econômicos. Tinha-se em vista, então, o planejamento a nível federal de uma industrialização associada, fortemente baseada em empreendimentos industriais de grande envergadura.

A partir disso, ocorreu a negociação entre governo do estado e Eletrobrás sobre a fusão ESCELSA/CCBFE - criando uma empresa de energia. Segundo relata Luiz Claudio Ribeiro (2013), uma das pautas desta negociação relacionava-se ao

${ }^{184}$ Rubens Rangel fica no cargo de governado entre a renúncia de Francisco Lacerda de Aguiar, em 05 de abril de 1966 e 31 de janeiro de 1967, posse de Christiano Dias Lopes Filho. 
medo de que o governo do estado tinha perante a possibilidade da nova empresa ser controlada por uma afiliada da Eletrobrás de outro estado da federação, em que os interesses capixabas acabariam sendo subjugados aos interesses de outros governos estaduais - ou de outro grupo de elites políticas regionais. Além disso, outra questão era a necessidade de investimento da nova empresa em pontos do território capixaba que não seriam tão rentáveis, pequenos projetos que pudessem propiciar algum desenvolvimento econômico ao longo de todo território.

As diretrizes desta negociação foram percebidas nas mudanças administrativas na CCBFE após passar para o controle da Eletrobrás. Uma dessas mudanças foram os ajustes para as obras e previsão de aumento da capacidade energética a partir de 1967, o que faz a oferta nominal de energia da empresa subir $127 \%^{185}$, a partir da ampliação e conversão dos sistemas Escelsa-CCBFE, e quando concluída a construção da usina de Mascarenhas ${ }^{186}$. A fusão entre Escelsa e CCBFE, no Espírito Santo, era entendida como inevitável e cada vez mais próxima. O primeiro indício da fusão foi a substituição de Asdrúbal Soares, diretorpresidente da empresa desde 1958, por Firmo Ribeiro Dutra, do quadro técnico da Eletrobrás ${ }^{187}$. Dutra também era ex-funcionário da empresa Cia. Auxiliar de Empresas Elétricas Brasileiras (CAEEB), uma das empresas do grupo ANFORP, e tinha a missão de preparar a unificação dos sistemas das empresas imprimindo condições de execução do plano de investimentos que o governo federal tinha para o Espírito Santo.

É relevante apontar que, além de um projeto que se relacionava a uma conjuntura de modernização estatal do Espírito Santo, sob a perspectiva do planejamento da interligação do sistema no centro-sul do país, a empresa que seria formada com a fusão Escelsa/CCBFE seria pensada como uma interligação de estruturas administrativas e operacionais, subordinadas à transmissão e distribuição da CEMIG no Espírito Santo, além da construção, operação e transmissão da energia gerada pela Usina Hidrelétrica de Mascarenhas ${ }^{188}$.

\footnotetext{
${ }^{185}$ De $66918 \mathrm{~kW}$ para $170900 \mathrm{kw}$.

${ }^{186}$ Além disso, houve também a orientação por parte da Eletrobrás para a expansão do seu sistema, com linhas de transmissão entre Vitória e Governador Valadares, para a interligação plena com a rede da CEMIG, a energia produzida por Furnas e Peixoto.

${ }^{187}$ ESCELSA. Relatório da Diretoria, 1965.

${ }^{188}$ Localizada no Rio Doce, na divisa com o estado de Minas Gerais. Inaugurada em 1974.
} 
Em 27 de outubro de 1967, a Assembleia Legislativa sanciona a Lei Estadual $n^{\circ} 2305$, que autorizava de forma definitiva a fusão da CCBFE com a Escelsa e a transferência da nova empresa para o controle federal. Já em 2 de janeiro de 1968 foi empossada uma diretoria comum às duas empresas, formada pelo presidente Carlos Alberto Pádua Amarante, figura próxima a Firmo Dutra ${ }^{189}$. Assim, a nova Espírito Santo Centrais Elétricas S/A (ESCELSA) é criada, já que nas palavras do governador, antes deste momento a Escelsa,

[...] que em certo momento de nossa história foi a afirmação da capacidade do capixaba para superar suas próprias necessidades e constituiu um fator extraordinário para nos retirar do imenso atraso de disponibilidades energéticas em relação ao Brasil, não tinha a menor perspectiva de ampliar sua capacidade de geração. ${ }^{190}$

Mas toda esta questão da fusão da ESCELSA e CCBFE era paralela à situação social e econômica do Espírito Santo na época. É importante dizer que a correspondência do estado com os seus vizinhos naquele momento baseava-se apenas em simples proximidade geográfica, ao serem analisados os indicadores econômicos como renda per capita, distribuição setorial do produto interno bruto, urbanização etc., o que valeu o apelido de "Nordeste sem Sudene"191. Para se ter uma ideia, em 1965 o Espírito Santo registrava uma renda per capita equivalente a $33,7 \%$ da renda per capita da região Sudeste.

Diante das necessidades capixabas, foi realizado, de janeiro a fevereiro do mesmo ano de constituição da "nova" Escelsa, em 1968, o Simpósio sobre os problemas do Espírito Santo, realizado pelo Clube de Engenharia do Rio de Janeiro. O simpósio teve como participantes o Presidente Gen. Arthur Costa e Silva, ministros e dirigentes, além de diversos representantes de órgãos federais de desenvolvimento regional.

Apesar de uma certa inoperância do grupo de trabalho criado a partir deste simpósio, houve alguns resultados importantes. Sua principal contribuição refere-

\footnotetext{
${ }^{189}$ Luiz Claudio M. Ribeiro (2013), ressalta ainda que, mesmo após a fusão entre as empresas, foram mantidos os repasses aos principais credores, como a própria AMFORP, a Usaid, AEG-Berlim, Eximbank, BID, BNDE entre outros. Tudo isso caracterizando os interesses envolvidos no setor elétrico capixaba e as complexas relações de financiamento empreendidas pelo governo brasileiro junto a instituições de crédito e agencias nacionais e internacionais.

${ }^{190}$ Mensagem do Governador Christiano Dias Lopes Filho à Assembleia Legislativa correspondente ao exercício de 1968. In: Estado do Espírito Santo: um estado em marcha para o desenvolvimento. Vitória: 1969 , p.38.

${ }^{191}$ MEDEIROS, 1977, p. 19.
} 
se às propostas apresentadas para a recuperação econômica, que apontavam para o setor industrial como o único com capacidade de desenvolver a economia capixaba, com destaque para siderurgia, atividades florestais, indústrias produtoras de insumos básicos para a construção civil, indústria de café solúvel e frigoríficos. Também se concluiu que seria necessária a ação do Estado na criação de um sistema de incentivos fiscais. A discussão e construção deste sistema ficou a cargo do Ministério do Planejamento, que no fim de agosto de 1969, como primeira medida, levou a inclusão da parte norte do Espírito Santo na SUDENE ${ }^{192}$.

Sobre este aspecto, o então governador Christiano Dias Lopes, na apresentação da proposta, dirigiu-se ao então ministro do Planejamento, aceitando a impossibilidade de inserção completa do Espírito Santo na SUDENE:

\begin{abstract}
"O Espírito Santo compreende e aceita a inviabilidade de ser, a esta altura, incluído na área da SUDENE. Também compreende que é do mais alto interesse nacional que não se altere a legislação de incentivos destinados à execução da política de desenvolvimento do nordeste. Igualmente já não deseja nenhum tratamento que signifique drenar para seu território recursos de outras áreas que seriam destinados ao nordeste. Hoje, o que o Espírito Santo vem pedir ao Governo Federal é que, pelo menos, os recursos gerados no Espírito Santo sejam retidos aqui, para nos ajudar no esforço imenso de superação da crise. A fórmula é simples e irrespondível: o contribuinte do Imposto de Renda, pessoa física ou jurídica, residente ou sediado no Espírito Santo, poderá aplicar em projetos considerados de interesse para o desenvolvimento do estado" $" 193$.
\end{abstract}

$\mathrm{Na}$ esteira desta inserção parcial do Espírito Santo na SUDENE, foi criado também o Fundo de Recuperação Econômica do Estado do Espírito Santo (FUNRES), o Fundo de Desenvolvimento Agrícola e Industrial (FUNDAI) e o Fundo de Desenvolvimento das Atividades Portuárias (FUNDAP) ${ }^{194}$. A respeito

\footnotetext{
192 A Superintendência do Desenvolvimento do Nordeste (SUDENE) foi criada pela Lei no 3.692, de 15 de dezembro de 1959, com o objetivo de promover e coordenar o desenvolvimento da região Nordeste. Sua instituição envolveu a definição do espaço que seria compreendido como Nordeste e passaria a ser objeto da ação governamental: os estados do Maranhão, Piauí, Ceará, Rio Grande do Norte, Paraíba, Pernambuco, Alagoas, Sergipe, Bahia, parte de Minas Gerais e parte do Espírito Santo.

${ }^{193}$ ESPÍRITO SANTO, 1979, p. 20.

${ }^{194}$ Em 10 de setembro de 1969, a Junta Militar, que havia substituído o Presidente Costa e Silva, assina o Decreto 880 que criava um fundo com recursos de Imposto de Renda das pessoas físicas e jurídicas residentes e domiciliadas no Espírito Santo, nos mesmos percentuais concedidos ao Nordeste. Isso foi fundamental para os investimentos no Espírito Santo naquele momento, e especialmente, para a do FUNDAP. O Fundo foi criado pela Lei ${ }^{\circ}$. 2.508 de 1970, e reforçado pela Lei 2.592 , de julho de 1971 e a ideia básica era otimizar a utilização dos portos capixabas para a intensificação dos fluxos comerciais, com foco nas importações, já que as exportações eram incentivadas por leis federais, gerando poucos recursos diretos ao Estado. Assim, os objetivos eram promover o estímulo à movimentação de mercadorias pelos portos do Espírito Santo. A viabilidade dessa iniciativa era baseada na conclusão das obras da BR 101 e 262 e no aproveitamento da ferrovia
} 
desta política de fundos, Arlindo Villaschi, Secretário de Planejamento do Espírito Santo em 1979, comenta:

“[...] Em primeiro lugar, viabilizou a geração de fluxos de importação pelos portos capixabas, até então majoritariamente utilizados para exportações. [...] Em segundo lugar, o incentivo financeiro concedido as importações (financiando subsidiado do imposto de circulação de mercadorias - ICM), tinha contrapartida a exigência de o beneficiado realizar direta ou indiretamente investimentos em projetos produtivos voltados para o desenvolvimento capixaba." 195

Ademais, através da lei 2.413/69, foi constituído o Banco de Desenvolvimento do Espírito Santo (BANDES), com a atribuição central de fornecer financiamento a programas e empresas que tivessem como objetivo o desenvolvimento estadual de médio e longo prazo. Importante demonstrar as mudanças setoriais na economia capixaba entre 1960 e 1970, e notar as mudanças econômicas setoriais na economia capixaba:

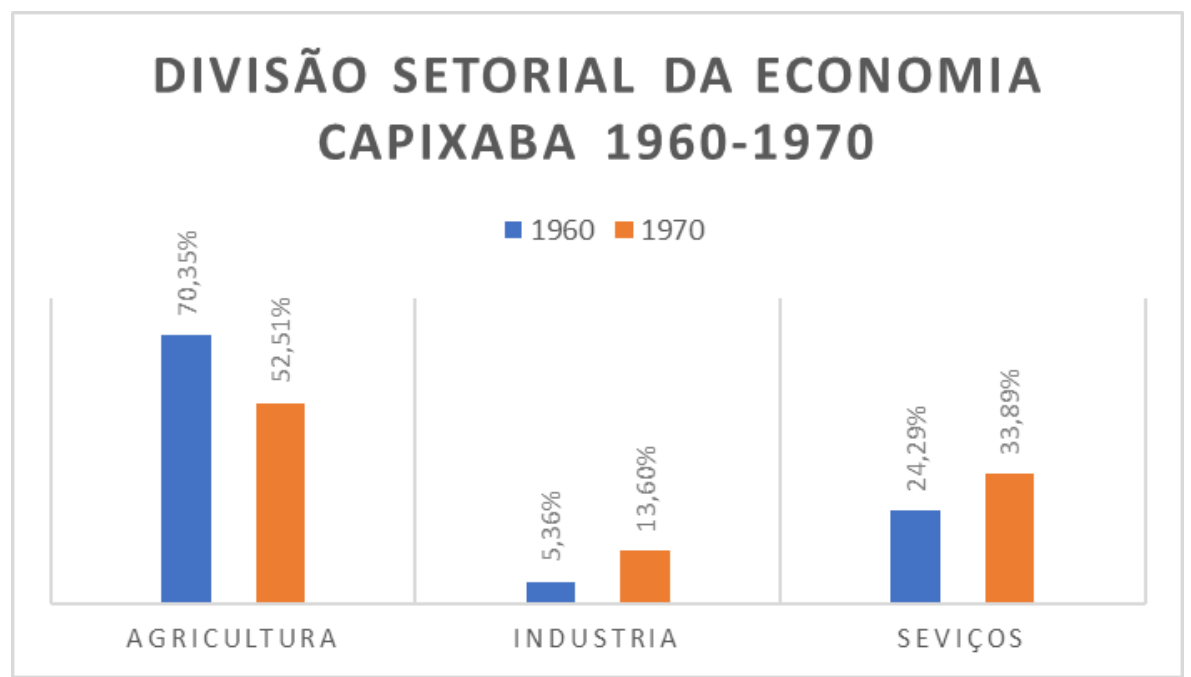

Gráfico 2 - Fonte: Dados Setoriais PEA e Renda. Secretaria de Planejamento do Espírito Santo (SEPJ). Vitoria, 1978.

Em outra dimensão, aprofundava-se a natureza técnica dada a formulação das políticas governamentais, o que refletia no aumento da distância entre o regime militar em âmbito federal e os legislativos estaduais. Foi neste ínterim que o segundo "biônico" da história do Espírito Santo, Arthur Carlos Gerhart Santos (1971-1974), foi escolhido - escolhido, inclusive, em lista tríplice pelo Presidente

Vitória a Minas. O que também, pela sua natureza de mecanismo financeiro, aumentava a renda gerada no território capixaba, a partir do financiamento das atividades econômicas nos setores industriais e de serviços (FELIPE et al. 2010, p. 12).

195 Villaschi, Arlindo. Revisitando o tema Fundap. Blog de Economia Capixaba. Disponível em: http://www.economiacapixaba.worldpress.com/2012/02/06/86/. Acessado em 08/10/2020. 
Gen. Emílio Garrastazu Médici. Santos era oriundo dos quadros da Federação das Indústrias do Estado do Espírito Santo (FINDES) e mantinha fortes relações com a Companhia Vale do Rio Doce (CVRD).

Santos, na nomeação do seu secretariado, priorizou secretários advindos de empresas privadas e públicas e da burocracia estatal federal ${ }^{196}$, ele demonstrava que a intenção era continuar com o projeto de desenvolvimento capixaba, se sustentando no modelo de modernização tecnocrática estatal localizado historicamente no apogeu da ditadura militar brasileira.

São, então, implementados seguindo estas diretrizes, os projetos que ficaram conhecidos como Grandes Projetos de Impacto (GP's). Os GP's ampliaram o papel da Companhia Vale do Rio Doce no desenvolvimento de vários setores da economia capixaba, além de agregarem os projetos de uma fábrica de celulose (Aracruz Celulose), portuária e logístico (integração com centro-oeste do país através do porto de Tubarão), naval (estaleiros) e turístico. Tal cenário fica explícito em entrevista dada por Arthur Carlos Gerhart Santos em 1974:

\begin{abstract}
“[...]Logo após minha posse, em conversa com o então ministro Delfim Neto, reforcei ainda mais a minha posição com referência aos investimentos externos, quando definimos que o Espírito Santo só poderia ter um processo de derramagem econômica, com a execução de projeto de igual ou maior envergadura que a Companhia Vale do Rio Doce. Isso porque, ela ficava isolada no panorama econômico do estado e seu efeito multiplicador era insuficiente para dinamizar a economia capixaba nos níveis desejados." ${ }^{197}$
\end{abstract}

Assim, também a indústria de transformação no Espírito Santo, entre a década de 1960 e 1970, apresentou elevadas taxas de crescimento - acompanhando o aumento da participação da indústria nos setores da economia capixaba -, o que possibilitou um aumento significativo de sua participação na geração da renda estadual. A taxa média anual de crescimento da produção $(15,8 \%)$ evidencia a grande dinamicidade do setor e sugere a extensão das alterações em suas dimensões, que de 1.600 estabelecimentos e 7.300 operários, em 1959, passou a 2.796 estabelecimentos e 28.681 operários em $1975^{198}$.

A partir de então, a industrialização capixaba caracterizou-se por significativa expansão dos gêneros tradicionais, sob o comando do capital nacional

\footnotetext{
${ }^{196}$ Falar do secretariado de Arthur. Pg. 262 de elites capixabas no golpe de 1964.

197 SANTOS, Arthur Carlos Gerhardt. O Pequeno Grande Estado. Revista Espírito Santo Agora. Vitória, Ano III, n. 11, p. 10, fev. 1974.

${ }^{198}$ ROCHA, H. C.; MORANDI, A. M. Cafeicultura e grande indústria: a transição no Espírito Santo 1955-1985. Espírito Santo em Ação. 2.ed. Vitória, 2012.
} 
e internacional, que encontrou condições altamente favoráveis, tanto em termos de crescimento do mercado consumidor, quanto de disponibilidade de incentivos fiscais e financeiros ofertados pelo estado.

Este cenário fez com que o abastecimento de energia elétrica pelo sistema da "nova" ESCELSA chegasse, em 1970, ao pico de $196763 \mathrm{kw}^{199}$, mais do que o planejado para o período, que era de $170.900 \mathrm{~kW}$. Agora, mais do que nunca, a expansão do sistema estava menos relacionada ao caráter regional da produção, e mais à interligação com sistema elétrico nacional e ao Plano 90, que concebeu vários projetos de geração de energia em larga escala, centralizados em determinadas regiões do país. O que possibilitava ao Espírito Santo, até aquele momento, assegurar um suprimento de energia completo para o todos os setores da economia, sem nenhum grande investimento em produção interna.

Adequa-se, assim, o interesse em manter a disponibilidade energética em benefício da produção planejada para os empreendimentos federais, como no caso da CVRD e da COFAVI; ou mesmo em empreendimentos privados, cujos investimentos eram definidos pela cúpula técnico-burocrática do governo militar federal, que ocupava os órgãos de decisão do planejamento e financiamento, como ocorreu com a Aracruz Celulose ${ }^{200}$.

Em 1974, o consumo industrial representava 21,4\% do consumo total de energia elétrica do estado, e no ano seguinte conclui-se cinco estudos de planejamento de um Sistema Espírito Santo com cronograma de obras até 1980, com o objetivo de atender ao mercado previsto de 656MW.

Com a predominância de projetos e recursos federais, a ESCELSA continua ampliando sua infraestrutura, em 1975, a capacidade de produção atinge aproximadamente 180,8 MW, compondo o Sistema ESCELSA neste ano: 11 usinas hidráulicas, 2 térmicas, 31 subestações, $1.555 \mathrm{Km}$ de linhas de transmissão, interligando-se ao sistema de Furnas pela subestação Cachoeiro de Itapemirim e de

\footnotetext{
${ }^{199}$ Na primeira metade dos anos 1970 foi concluído o programa de conversão de frequência para 60 Hz e iniciada a interligação do sistema elétrico do Espírito Santo com o da Região Sudeste, concluída até o final da década (BITTENCOURT, 1984). A construção dessas três unidades proporcionou ao Espírito Santo a autossuficiência até meados da década.

${ }^{200}$ Segundo Silvestre e Rodrigues (2007), a primeira fábrica da Aracruz Celulose S/A surge após uma bem-sucedida negociação do grupo Lorentzen, da Noruega, JakkoPoyry, da Finlândia e Billerud-A.B. da Suécia, com a burocracia da ditadura militar do general Ernesto Geisel. O Banco Nacional de Desenvolvimento Econômico (BNDE) financiou US\$ 337 milhões do total de US\$ 536 milhões do empreendimento, inaugurado com a presença do Presidente Geisel em 1978.
} 
Minas Gerais pela subestação de Governador Valadares ${ }^{201}$. No mesmo ano se termina, ainda, a interligação do Norte do Estado com o sistema da Região Sudeste e a troca da frequência para $60 \mathrm{~Hz}^{202}$.

Paralelo ao crescimento da infraestrutura elétrica, entre 1975 e 1980 outros setores da indústria de base e de transformação crescem à taxa média anual de 11,5\%. O gênero que mais apresentou variação foi papel e papelão, que em 1975 tinha o peso irrelevante de $0,1 \%$ no valor total da produção industrial, e em 1980 aumentou para $11,5 \%$, tornando-se o segundo mais importante - só superado por produtos alimentares, com 32,9\%. Esse enorme crescimento estrava atrelado, principalmente, à implantação da fábrica de celulose branqueada da Aracruz Celulose S/A, que entrou em operação no ano de 1979. Uma das maiores fábricas do ramo no Brasil, com capacidade nominal de produção de 475 mil t/ano e que destinava aproximadamente $80 \%$ da sua produção ao mercado externo.

Nos parece viável concluir que, a partir de 1975, acompanhado de um cenário nacional político e econômico favorável, o setor industrial no Espírito Santo ganhou mais contornos e características, desencadeado por um processo crescente de diversificação da estrutura industrial. O que esteve relacionado em paralelo, a expansão dos investimentos no setor elétrico integrado ao sistema nacional.

4.2.1 Os governos da década Élcio Alvares (1975 a 1979), Eurico Resende (1979 a 1983) e a acentuação de um modelo desenvolvimento estatal eletrointensivodependente.

Ainda em 1975, toma posse o terceiro governador biônico capixaba, Élcio Álvares $^{203}$ (Arena). Álvares orbitava a antiga ala desenvolvimentista do PSD e

\footnotetext{
${ }^{201}$ BITTENCOURT, 1979, p. 79.

${ }^{202}$ Mesmo assim, o Espírito Santo chegaria à década de 1980 extremamente dependente do sistema nacional, com cerca de 30\% da energia distribuída proveniente do Sistema Nacional Interligado (SNI) e o restante de geração de FURNAS, com parte incipiente de geração interna.

${ }^{203}$ Élcio Alvares se filia ao Partido Social Democrático (PSD) em 1955. Advogado, entre 1963 e 1964 foi conselheiro da Ordem dos Advogados do Brasil (OAB), seção Espírito Santo. Após o golpe militar de 1964, que derrubou o presidente João Goulart (1961-1964), filiou-se à Aliança Renovadora Nacional (Arena). Atuava como advogado do grupo financeiro João Santos, quando, no pleito de novembro de 1966, elegeu-se suplente de deputado federal pelo Espírito Santo na legenda da Arena. Em novembro de 1970 foi eleito deputado federal. Assumiu a cadeira em março de 1971 e em novembro seguinte tornou-se vice-líder de seu partido na Câmara, cargo que ocuparia até 1973. Com a extinção do bipartidarismo em 1979 filiou-se ao Partido Democrático Social (PDS). Em janeiro de 1985, Élcio Álvares foi um dos fundadores do Partido da Frente Liberal (PFL). E depois de 11 anos afastado do exercício de cargos eletivos, integrou a coalizão do PFL com o PDS e outros partidos menores como candidato ao Senado pelo Espírito Santo, no pleito de outubro de
} 
representou a continuidade do caminho modernizador de Christiano Dias Lopes Filho e Arthur Carlos Gerhardt Santos. O I Plano de Desenvolvimento Estadual foi construído em seu governo, com um compromisso de continuidade com Grandes Projetos de Impacto (GP's).

A tônica principal do governo Élcio Álvares será a negociação política continuada com as elites políticas capixabas, o que tenta aglutinar, ao longo do seu governo, os anseios e os interesses destes grupos políticos em nome de um projeto convergente nacional ${ }^{204}$.

O setor siderúrgico foi o que recebeu maior atenção no governo Álvares. Sob a direção do governo federal, a Companhia Siderúrgica de Tubarão se tornou uma sociedade de economia mista, ficando o governo brasileiro com $51 \%$ do capital social e a Fisinder, sociedade italiana e a Kawasaki Steel, japonesa, com 24,5\% das ações cada. Esta seria a terceira grande empresa de expressão internacional do Espírito Santo, depois da CVRD e da Aracruz Celulose.

No plano da administração estadual, uma das suas principais ações foi tornar mais dinâmica as bases do sistema de planejamento, extinguindo o CODEC e marcando o início do funcionamento do Sistema Estadual de Planejamento do Espírito Santo, através da Lei n.3043, de 31 de dezembro de 1975. E assim foi criada a Secretaria de Planejamento (SEPLAN), com a formação de um corpo técnico e recrutando profissionais de outros órgãos da administração pública direta e indireta.

1990, onde foi eleito. Em 1992, Élcio Álvares integra a CPI mista destinada a apurar as denúncias sobre as atividades de Paulo César Farias e, em agosto foi o primeiro senador do PFL a romper apoio ao presidente Fernando Collor de Melo. Nomeado ministro da Indústria e Comércio do governo Itamar Franco, assumiu a pasta em janeiro de 1994. Álvares concluiu sua gestão à frente do ministério em 31 de dezembro de 1994, ao final da gestão de Itamar Franco. No início de 1996, foi um dos principais estrategistas do governo para conseguir a aprovação, pelo Senado, do Sistema de Vigilância da Amazônia (Sivam). Em dezembro de 1998, foi escolhido pelo presidente Fernando Henrique Cardoso, novo Ministério da Defesa, que viria substituir as pastas do Exército, da Marinha, da Aeronáutica e o Estado-Maior das Forças Armadas (EMFA). Deixando o Ministério da Defesa em janeiro de 2000. Secretário do Planejamento de Viação e Obras Públicas no Espírito Santo de fevereiro de 1966 a janeiro de 1967, durante os governos de Francisco Lacerda de Aguiar (19631966) e de Rubens Rangel (1966-1967). Também em 1967, diretor-presidente da Companhia de Desenvolvimento Econômico do Espírito Santo (Codes), atual Banco de Desenvolvimento Econômico do Espírito Santo (Bandes). Durante o ano de 1969 exerceu o cargo de diretor-presidente da Associação Brasileira de Bancos de Desenvolvimento (ABDE). Indicado pelo senador, naquele momento, da Aliança Renovadora Nacional (Arena) Carlos Lindemberg, para o cargo de governador do Espírito Santo nas eleições indiretas de outubro de 1970, foi eleito pela Assembleia Legislativa assumindo o governo em 1971 e indo até 1975. CPDOC (FGV). Dicionário Histórico-Biográfico Brasileiro On-line: Élcio Álvares. Rio de Janeiro, 04 dez. 2020. Disponível em: http://www.fgv.br/cpdoc/acervo/dicionarios/verbete-biografico/alvares-elcio

204 OLIVEIRA, 2013. 
Além disto, o governo de Álvares promoveu uma política de contenção de despesas, visando regularizar os pagamentos e o custeio da saúde pública estadual que estavam em atraso, além de contratar operações de crédito, que chegaram a comprometer $21 \%$ das receitas estaduais.

Foi criada também a Fundação Jones dos Santos Neves (IJSN), para auxiliar os estudos da Seplan, com a elaboração e execução de estudos, pesquisas, planos, projetos, programas de ação e organização de bases de dados estatísticos e georreferenciados, nas esferas estadual, regional e municipal, voltados ao desenvolvimento socioeconômico do Espírito Santo. O Decreto n.831-N, de 7 de maio de 1976, em seu artigo $3^{\circ}$ definiu seus objetivos:
“a) Programar e executar pesquisas que subsidiem melhor equacionamento dos problemas econômicos e sociais, fornecendo suporte técnico ao Governo Estadual na elaboração de seus programas de desenvolvimento.
b) Formular diagnósticos, realizar estudos e promover a elaboração de planos de desenvolvimento urbano e regional, auxiliando o funcionamento da Seplan.
c) Auxiliar, sempre que necessário, as ações do Poder Público que forem de interesses dos municípios.
d) Manter informações referentes aos aspectos socioeconômicos do Espírito Santo.
e) Formar recursos humanos (técnicos) para o fomento de estudos ligados às especificidades da realidade capixaba."

A criação da Fundação Jones dos Santos Neves foi ainda uma iniciativa, no sentido de dar à administração pública local as condições técnico-científicas e financeiras para pesquisa dos problemas com que se deparava o estado. É possível dizer que é a partir do governo Álvares que as técnicas de planejamento no Espírito Santo aprofundaram sua importância dentro da máquina estatal.

Com a criação da Secretaria de Planejamento (SEPLAN) permitiu também a construção de programas setoriais e planejados, permitindo ações qualitativas e quantitativas a prazo, por meio de estudos técnicos mais aprofundados, de acordo com às particularidades históricas e geográficas capixabas. Serviu também como instrumento de pressão junto ao Governo Federal, uma vez que seria possível pedir à União os recursos complementares necessários, a partir dos estudos e diagnósticos produzidos.

Relevante destacar que a política formulada por Élcio Alvares esteve também direcionada a interiorização com o objetivo de descentralizar os projetos do entorno de Vitória, direcionando recursos para a eletrificação rural, telefonia, infraestrutura viária e moradia rural. 
Esta guinada ao interior tem a ver com alguns aspectos. O primeiro deles refere-se ao enorme crescimento populacional da Região metropolitana de Vitória (Grande Vitória), que entre as décadas de 1960 e 1980 registrou um aumento de $356,22 \%$, passando de 198.265 para $706.263^{205}$. A ideia era diminuir a migração das áreas rurais para a região metropolitana. Já o segundo relaciona-se à estreita relação de Alvarez com as elites agroexportadoras capixabas, que se mantinham subalternas ao desenvolvimento industrial desde a década de 1960. Estas dependiam dos recursos financeiros do Fundo de Desenvolvimento Econômico do Espírito Santo (FUNRES), que incentivava projetos agropecuários, mas que não propunha uma reforma agrária ou alteração na estrutura fundiária. Houve, neste ponto, a retomada da expansão da lavoura cafeeira, a primeira após a crise do café e erradicação dos cafezais da década de 1960. Agora, em moldes empresariais e com modernização tecnológica.

Por sua vez, o governador biônico sucessor de Alvares, Eurico Resende (ARENA), que irá governar entre 1979 e 1983, tenderá ao aprofundamento em relação ao planejamento estadual e a sua política econômica. Em 27 de outubro de 1980, por meio do Decreto n.1.469-N, todas as fundações estaduais são remodeladas, transformando-se em autarquias. Dentre elas, a Fundação Jones dos Santos Neves, que passa a se chamar Instituto Jones dos Santos Neves.

Tal decreto uma tentativa de reorientar os recursos internos para novas frentes e estimular a captação de capitais no exterior, um mecanismo criado com o propósito de dinamizar a expansão industrial e maximizar os lucros dos setores tradicionais da economia local. Porém, a ideia de um sistema estadual de planejamento só se concretizou no texto da lei, pois na prática isso não aconteceu. Isto é observado através do papel que deveria exercer a Secretaria de Estado do Planejamento (SEPLAN), no planejamento estadual, tendo como subordinados o Banco de Desenvolvimento Econômico do Espírito Santo (BANDES) e o Instituto Jones dos Santos Neves. Não houve qualquer controle administrativo efetivo da Seplan sobre estes órgãos, restando ao Instituto produzir estudos, projetos e programas, não sendo possível sedimentar o planejamento estadual como o desenhado por Resende.

\footnotetext{
${ }^{205}$ Dados Adaptados e de construção própria obtidos de FIBGE, Censo Demográfico do ES.
} 
O papel do BANDES também chama a atenção neste momento. Caberia ao banco oferecer o suporte técnico para a "estruturação de uma classe produtiva, estimulando elementos locais e/ou promovendo a transferência para o Estado de empresários de outras regiões" ${ }^{\text {206 }}$. Esperava-se ainda que o banco continuasse com os investimentos nas atividades econômicas tradicionais, além de identificar novos setores dinâmicos passíveis de recursos.

\subsection{A década de 1980: a política de um setor elétrico em um outro contexto federalista}

Com o passar das décadas do regime militar, as ações das estatais são cada vez mais centralizadas na dimensão federal, restringindo a atuação regionalizada. Deste modo, se por um lado, estavam os estados dependentes dos recursos e do planejamento público federal, por outro, um governo nacional com poder cada vez mais sem legitimidade popular.

Tomando como referência as análises de Ricardo Ismael (2005) sobre o Nordeste, é importante observar que a cooperação insulada entre os entes da federação na década de 1980 ficou sem sustentação política, mas não ficou totalmente desaparecida, como alternativa para boa parte das forças políticas. Este padrão cooperativo tornou-se, com a criação da SUDENE, uma referência obrigatória na cultura política nordestina e igualmente, um movimento motivador para as discussões sobre o desenvolvimento econômico das regiões brasileiras.

Mas este terceiro momento da experiência federalista brasileira começa com a eleição dos governadores de forma direta em $1982^{207}$. Agora com a legitimidade das urnas, os governadores passaram a redefinir em novas bases a relação com o governo federal, marcando a retomada do federalismo no Brasil ao devolverem aos estados o direito de escolherem seus governantes.

Para além da conjuntura política, o momento deste novo contexto federalista se deparada com um processo inflacionário crônico, com o esgarçamento da capacidade fiscal e, por consequência, a uma acentuada redução dos meios para financiar o desenvolvimento.

\footnotetext{
${ }^{206}$ ESPÍRITO SANTO, 1980, p. 40

${ }^{207}$ Relembrando, a primeira se inicia com a Proclamação da República em 1889 e a segunda ao fim da era Vargas, em 1947.
} 
Esse quadro geral de dificuldades condicionou as proposições descentralizadoras do federalismo proposto pela constituição de 1988. Representativa de um conjunto de anseios democráticos e de tentativas de superação das amarras centralizadoras do sistema político do período ditatorial (1964-1985), a Constituição de 1988 propugnava para o federalismo brasileiro maior descentralização política e de recursos ${ }^{208}$.

O reconhecimento dos municípios como entes federados já representava de alguma forma tais mudanças. Um novo conjunto de relações federativas, com maior protagonismo dos governos estaduais, foi pensado a partir daí. O texto constitucional de 1988 estabeleceu, por exemplo, que competia à União “elaborar executar planos nacionais e regionais de ordenação do território e de desenvolvimento econômico e social" ${ }^{209}$.

Contudo, a Assembleia Nacional Constituinte contemplou também uma maior distribuição e participação nas receitas públicas de estados e municípios. Triunfou a ideia de que os entes federados precisavam, além de autonomia política, maior participação no bolo do orçamento público federal.

A descentralização, então, redefiniu as relações intergovernamentais, na medida em que ampliou o poder dos governadores estaduais e municipais nas decisões nacionais e restringiu os recursos federais para intervir na federação brasileira $^{210}$. Não obstante, é também certo dizer que ao final, o pêndulo histórico tendeu para uma reconcentração de poderes políticos, institucionais e financeiros em Brasília. As razões para esta centralização são muitas, mas é certo que se relacionam com a tarefas de reorganização do Estado em um contexto de dificuldades macroeconômicas de grande monta ${ }^{211}$, o que vai ficar explícito nas dinâmicas do setor elétrico na década.

\subsubsection{O colapso do setor elétrico}

Uma grave crise do setor elétrico adentra a década de 1980 e deixa evidenciada as limitações dos instrumentos de controle do Estado e a deterioração

\footnotetext{
${ }^{208}$ MONTEIRO NETO, Aristides. Governos estaduais no federalismo brasileiro: capacidades e limitações no cenário atual. Texto para discussão / Instituto de Pesquisa Econômica Aplicada. Brasília - Rio de Janeiro: Ipea, 2013.

${ }^{209}$ Senado Federal. Constituição da República Federativa do Brasil: quadro comparativo. Brasília, Senado Federal, 1996, pp. 99 e 441.

${ }^{210}$ SOUZA, 1997, pp. 171-180.

${ }^{211}$ ARRETCHE, 2012; FILHO, 2012; OLIVEIRA, 2007.
} 
das relações entre empresas estaduais e a Eletrobrás, com a eclosão de conflitos de natureza financeira e institucional.

Dois pontos merecem especial atenção neste colapso brasileiro: 1) o primeiro relaciona-se à subordinação do setor aos interesses da política macroeconômica, já mencionada aqui; e 2) o segundo trata-se do surgimento de contradições internas ao próprio setor decorrentes do modelo institucional.

Como explica Monica Landi (2005), na intenção de atingir os objetivos propostos pelo II PND, a Eletrobrás ${ }^{212}$, assim como as demais empresas estatais brasileiras, foram estimuladas a captar recursos externos como forma de financiar seus expressivos investimentos. Ainda em 1978, tais inversões representaram mais de $10 \%$ do volume global de investimentos realizados no país, assumindo papel de destaque na sustentação do investimento estatal. Com isso, há uma estratégia deliberada do governo federal em viabilizar crescimento interno com endividamento externo, que acabou por redundar na própria estatização da dívida externa brasileira.

Paralelamente, o segundo choque do petróleo e a alta dos juros internacionais revelaram o esgotamento dessa capacidade de endividamento, acelerando o processo de estrangulamento econômico-financeiro do setor público. No caso específico do setor elétrico, se tem o esgotamento das transferências de recursos fiscais para o setor, com a utilização das tarifas como instrumento de política econômica.

Mais a adiante na década de 1980, em 1985, o último presidente do período ditatorial, José Sarney (PMDB), ao assumir o cargo, defrontou-se com uma crise econômica impulsionada por uma violenta pressão inflacionária, que acabaria por deslocar o debate político para as questões econômicas de curto prazo e para a polêmica dos planos de estabilização que se sucederam.

O setor elétrico, a essa altura, como ferramenta de política de governo, dada sua capacidade de gerar reflexos específicos sobre determinados segmentos da sociedade, se encontrou novamente em uma situação paradoxal. Poderia ter acesso a diferentes fontes de financiamento, ao mesmo tempo que a sua própria função de

\footnotetext{
${ }^{212}$ Neste momento, a ELETROBRÁS era o braço empresarial do Estado no setor elétrico, agente de financiamento setorial que, além de exercer as decisões de investimento estatal, cumpria as funções de coordenação, planejamento e operação de todo o sistema elétrico nacional, incluindo as empresas estaduais e as pequenas concessionárias de capital privado.
} 
prover suporte a determinadas políticas econômicas determinava a exposição das concessionárias do serviço público de eletricidade ao desequilíbrio financeiro. Neste momento, há a combinação de perda de fontes de financiamento e aumento dos custos internos e tarifas que já não refletiam a realidade da concessão.

Incapacitadas de realizar o volume de investimentos necessários para acompanhar a expansão e manutenção dos serviços, as empresas ainda tinham que conviver com a fragilidade do órgão regulador (DNAEE) ${ }^{213}$, que deixava o setor elétrico nacional à mercê de erros de planejamento, interesses políticos locais e pressões de grupos de interesse vinculados ${ }^{214}$ às empreiteiras ou outras empresas ligadas à indústria eletrotécnica. Como forma de contornar todo este imbróglio, e visando capitalizar as dívidas do setor elétrico, o governo federal intensificou a transferência do endividamento do setor elétrico para o Tesouro Nacional, que passou a operar efetivamente como mecanismo de financiamento das obrigações externas vencidas.

No gráfico 3 é possível observar esta evolução dos empréstimos e financiamentos ao longo da década. Duas constatações são imediatas: (1) o crescimento e o grande peso do endividamento em moeda estrangeira em 1980 e 1987, e (2) a diminuição considerável do endividamento, no mesmo momento de uma crise aguda no setor elétrico.

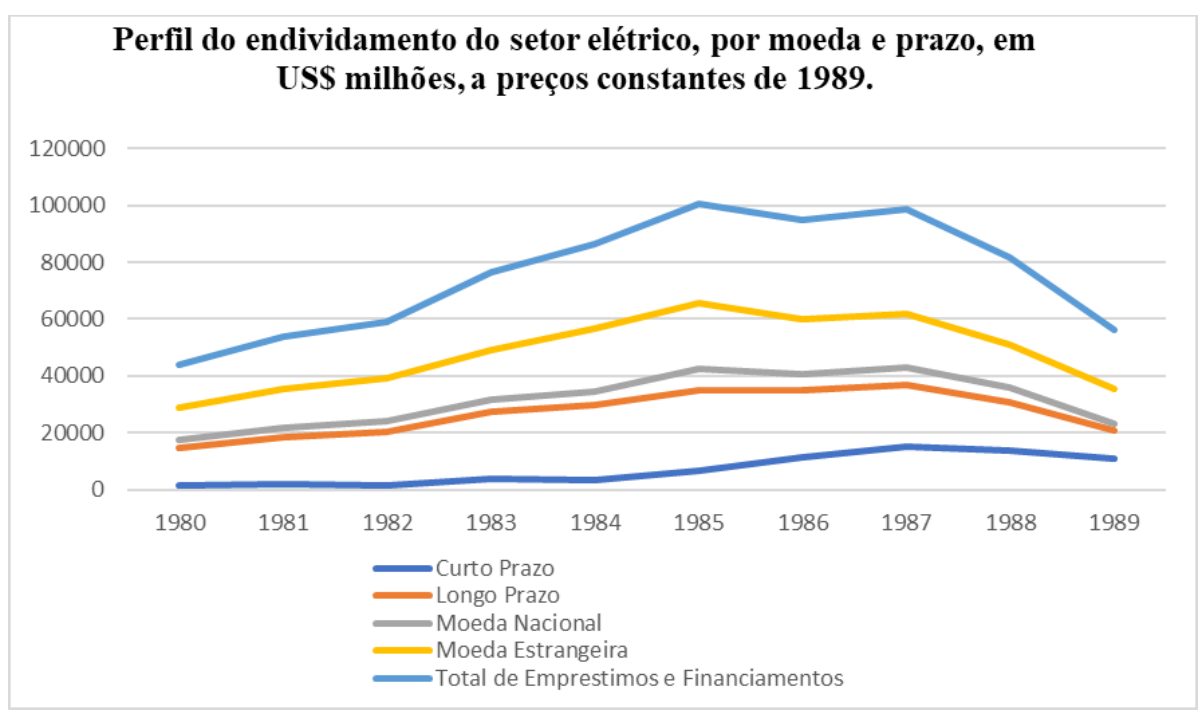

Gráfico 3 - Fonte: Eletrobrás e Landi (2005).

${ }^{213}$ Departamento Nacional de Águas e Energia Elétrica (DNAEE)

${ }^{214}$ ROSA, L., TOLMASQUIM, M., PIRES, J. C. L,1998. 
Com o esgotamento deste modelo para o setor, o marco institucionalregulatório passou a não mais ser observado, e as empresas passaram a não efetuar os pagamentos sobre a energia comprada do grupo ELETROBRÁS e da Usina de Itaipu. A inadimplência das concessionárias estaduais virou ferramenta de gestão empresarial, generalizando-se por todo o país e afetando os alicerces de operação do sistema elétrico nacional.

Por sua vez, os problemas de gestão nas concessionárias não só vão conduzir a um grave quadro institucional, como também vão fornecer subsídios aos argumentos pela privatização das empresas estatais do setor. Acertando precisamente, os sistemas elétricos regionais, como o setor elétrico capixaba, mesmo em crise, continuarão a perseguir o caminho traçado pelo desenvolvimento industrial. Quadro que irá refletir na crise de abastecimento que bater à porta ainda na década de 1990.

4.3.1 Um modelo de desenvolvimento em crise e que persiste: os governos Gerson Camata (1983 a 1986) e Max Mauro (1987 a 1991)

A segunda metade da década de 1980 no Espírito Santo foi, ao mesmo tempo, o período de uma segunda expansão do setor industrial eletrointensivo, e o lugar de uma profunda crise na gestão estatal capixaba, o que arrefece as iniciativas do Estado para o desenvolvimento.

Ao tomar posse como o primeiro governador capixaba fora do espectro da ARENA, em 1983, Gérson Camata ${ }^{215}$ (PMDB) representa o desafio que recebera

215 Gerson Camata, iniciou sua carreira profissional como jornalista e apresentador do programa Ronda da cidade, na Rádio Cidade de Vitória. Vereador em Vitória em 1967, na legenda da Aliança Renovadora Nacional (Arena). Em novembro de 1970 elegeu-se deputado estadual e deputado federal em novembro de 1974, pelo mesmo partido. Foi reeleito em novembro de 1978 e com a extinção do bipartidarismo em novembro de 1979, filiou-se ao Partido do Movimento Democrático Brasileiro (PMDB), de oposição ao governo. Em 1982 lançou sua candidatura ao governo do Espírito Santo, disputando com Carlito Von Schilgen, do Partido Democrático Social (PDS), governista. Venceu com 67\% dos votos válidos. Em 1986 foi eleito senador pelo Espírito Santo. Em outubro de 1994 reelegeu-se senador. Iniciando novo mandato em fevereiro de 1995, tornou-se terceiro-vice-líder do PMDB, cargo que manteria até janeiro de 1999, e passou a integrar as comissões de Educação e Infraestrutura, nas quais permaneceria até 1998. Em julho, às vésperas da convenção do PMDB para a escolha do candidato a governador do Espírito Santo, renunciou à pré-candidatura e anunciou seu apoio a José Inácio Ferreira, candidato da coligação formada pelo Partido da Social-Democracia Brasileira (PSDB), o PFL, o Partido Progressista Brasileiro (PPB), o Partido Liberal (PL) e o Partido Verde (PV). No pleito de 2002, foi reeleito para o terceiro mandato de senador pelo Espírito Santo na legenda do PMDB. Licenciou-se em maio 2006, quando, a convite do governador Paulo Hartung, assumiu a Secretaria de Desenvolvimento, Infraestrutura e Transportes do Espírito Santo no lugar de sua esposa, Rita Camata. CPDOC (FGV). Dicionário 
de seus antecessores: um déficit orçamentário de 42 bilhões de cruzeiros e dívidas em torno de 102 bilhões de cruzeiros.

Uma das principais marcas do governo Camata foram as tentativas de aproximação com o partido governista no estado e com a burocracia do governo federal, principalmente pela necessidade de contenção de despesas e de financiamento. Dentro deste contexto, o governador marca uma reunião com presidente Gal. Figueiredo, pessoa com quem teve problemas durante a campanha para o governo do estado ${ }^{216}$.

Superadas as divergências entre ambos, Camata recebera empréstimos federais a longo prazo e a fundo perdido. Conseguiria, dessa forma, rolar a dívida externa, regularizar o pagamento do funcionalismo e deslanchar seu programa de governo.

Camata escolhe Orlando Caliman para a Secretaria de Planejamento e Ricardo Santos para a de Agricultura, ambos ex-auxiliares de Eurico Resende e considerados por setores do PMDB "tecnocratas que sempre estiveram a serviço dos governos do PSD" - mas que formaram a base da ARENA no estado, durante o regime militar.

Do ponto de vista do modelo de desenvolvimento, Camata enfatizou o apoio à agricultura e ao homem do campo, através do avanço de projetos de eletrificação, construção de estradas e escolas. Justificou seu apoio à agricultura com o argumento de que essa atividade apresentava a vantagem de gerar um retorno rápido do ponto de vista tributário, enquanto a implantação de indústrias, por demandar do estado concessões fiscais, ocasionava uma baixa arrecadação de impostos.

Enquanto isso, em 1985, a CST utilizava $88,8 \%$ de sua capacidade e empregava diretamente 6,3 mil pessoas. Já a Companhia de Ferro e Aço de Vitória (COFAVI), cuja capacidade das unidades de laminação de aço era de $360 \mathrm{mi}$ t/ ano, aumentaria sua produção, chegando a um total de 500 mil t/ano.

A produção de gusa também se ampliou com a implantação de dois outros projetos de empresários mineiros: a Companhia Metalúrgica Vetorial, com

Histórico-Biográfico Brasileiro On-line: Gerson Camata. Rio de Janeiro, 04 dez. 2020. Disponível em: http://www.fgv.br/cpdoc/acervo/dicionarios/verbete-biografico/camata-gerson

${ }^{216}$ Durante a campanha, Camata havia chamado o Gal. João Figueiredo de "general mentiroso" durante a campanha ao governo do estado, sendo enquadrado na Lei de Segurança nacional (ibid, 2020). 
capacidade de 60 mil t/ano e a Ferroeste Industrial S/A, com capacidade de 100 mil t/ano, que entrou em operação em 1986.

Em maio de 1986, estimulado pelo presidente José Sarney (1985-1990), Camata volta ao senado e Max Mauro $^{217}$ (1987 a 1991) se torna governador do Espírito Santo, tendo como foco central, o saneamento das finanças do estado.

Com o processo de desenvolvimento que se inicia em 1990, que inaugura a abertura econômica, a liberalização comercial de 1994 a 1999 com o Plano Real e a paridade cambial de $\mathrm{R} \$ 1$ por US\$ 1 , fez com que houvesse um forte incremento das atividades de exportação e importações. O Espírito Santo se beneficiaria, sobretudo, com o Fundo de Desenvolvimento das Atividades Portuárias (FUNDAP), que financiava as empresas importadoras e que acabou por viabilizar o aumento em grande escala do volume de transações através dos portos capixabas.

\footnotetext{
${ }^{217}$ Max Freitas Mauro nasceu em Vila Velha (ES) no dia 11 de março de 1937, filho de Saturnino Rangel Mauro e de Maria da Penha Freitas Mauro. Seu pai foi sindicalista, fundador do Partido Trabalhista Brasileiro no Espírito Santo, em 1947, e seu primeiro presidente regional, tendo sido eleito, naquele ano, deputado estadual constituinte. Nas eleições de novembro de 1990, apoiou o candidato vitorioso Albuíno Cunha de Azeredo, da coligação Partido Democrático Trabalhista (PDT), Partido Socialista Brasileiro (PSB) e Partido Comunista do Brasil (PCdoB), a quem passou o cargo em março do ano seguinte. Em 1994 deixou o PMDB e se filiou ao Partido Trabalhista Brasileiro (PTB) e, concorreu ao governo do Espírito Santo no pleito de outubro desse ano, mas não conseguiu se eleger. Quatro anos depois, disputou, com êxito, uma vaga na Câmara dos Deputados, pela legenda petebista. Disputou o governo do Espírito Santo nas eleições de 2002 sendo derrotado por Paulo Hartung (PMDB-ES) e na disputa pelo Senado, em 2006, Max Mauro acabaria vencido por Renato Casagrande (PSB-ES). Um deles, Max Mauro Filho, também seguiu a carreira política. Vereador no município de Vila Velha entre 1989 e 1992, elegeu-se deputado estadual pelo PTB em 1994, reelegendo-se em 1998 com a maior votação do estado, elegendo-se prefeito de Vila Velha em 2004. CPDOC (FGV)Dicionário Histórico-Biográfico Brasileiro On-line: Max Freitas Mauro. Rio de Janeiro, 04 dez. 2020. Disponível em: http://www.fgv.br/cpdoc/acervo/dicionarios/verbetebiografico/max-freitas-mauro.
} 


\section{CAPÍtUlO 5 - DESCENTRALIZAÇÃO, DESESTATIZAÇÃo E REGULAMENTAÇÃO SOB OS AUSPÍCIOS DO ESTADO NACIONAL NA DÉCADA DE 1990}

\subsection{A privatização da Espírito Santo Centrais Elétricas S/A e o governo} Albuíno Azeredo (1991 a 1995)

O capítulo 5, busca explorar as mudanças ocasionadas pela transição de um regime político ditatorial para um democrático e pela crise no modelo de desenvolvimento nacional, que consequentemente, atingem o setor de energia elétrica. Conjuntura que leva a uma série de privatizações de empresas estatais regionais de energia, modificando as estruturas centralizadoras do setor elétrico nacional, colocando em xeque as dinâmicas políticas locais que davam suporte a este setor.

Neste cenário que no início de 1990 com o patrocínio do deputado federal Waldir Pires ${ }^{218}$ (PDT) da Bahia, o engenheiro Albuíno Azeredo ingressa no Partido Democrático Trabalhista (PDT) e candidata-se a governador do Espírito Santo, derrotando José Inácio Ferreira do Partido Social Trabalhista (PST) no segundo turno.

O período do seu governo será um momento de acentuações de processos nacionais em âmbito regional. Em primeiro lugar, se consolidam profundas transformações na estrutura socioeconômica capixaba, sobretudo, seu padrãourbano industrial. Depois, se abraça o movimento de globalização da economia mundial que significaria: privatização e abertura da economia.

\footnotetext{
${ }^{218}$ Francisco Waldir Pires de Sousa nasceu em Acajutiba (BA). Foi secretário de Governo do governador baiano Luís Régis Pacheco Pereira (PSD), de 1951-1955. Em outubro de 1954 elegeuse deputado estadual na Bahia na legenda do Partido Trabalhista Brasileiro (PTB), assumindo o mandato em fevereiro de 1955. Em maio de 1963 foi nomeado consultor-geral da República, substituindo Gilvan Correia de Queirós (1962-1963). Em 10 de junho de 1964 seguinte, com base no AI-1, Waldir Pires teve seus direitos políticos suspensos. Após um período de exílio no Uruguai, seguiu para a França. Em 15 de março 1985 foi assim empossado o vice-presidente José Sarney após a morte de Tancredo Neves -, que manteve os ministros escolhidos por Tancredo. Um deles era Waldir Pires, que assumiu o Ministério da Previdência e Assistência Social, sucedendo a Jarbas Passarinho. Empossado em 15 de março de 1987 no governo baiano. Convidado por Lula, presidente do PT, para filiar-se a esse partido em fins de 1989, Waldir Pires deu preferência ao PDT. Nessa legenda foi eleito deputado federal em outubro de 1990 . Ao se iniciar o governo Lula, em $1^{\circ} \mathrm{de}$ janeiro de 2003, Waldir Pires foi nomeado ministro-chefe da Corregedoria-Geral da União. E em 31 de março de 2006, Valdir Pires deixou a Controladoria-Geral da União para assumir o Ministério da Defesa, em substituição a José Alencar. CPDOC (FGV). Dicionário Histórico-Biográfico Brasileiro On-line: Francisco Waldir Pires de Sousa. Rio de Janeiro, 04 dez. 2020. Disponível em: http://www.fgv.br/cpdoc/acervo/dicionarios/verbete-biografico/francisco-waldir-pires-de-sousa
} 
Mas as privatizações no Espírito Santo começaram ainda em 1989, com a venda das ações da Aracruz Celulose e da COFAVI. Em 1992 e 1993 foi a vez da CST e ESCELSA, respectivamente. A CVRD seria um pouco depois, em 1997, restando nas mãos do governo federal, apenas, algumas áreas da infraestrutura portuária e aeroportuária, e dois bancos.

Assim, a abertura econômica teve reflexos diretos, principalmente em razão da implementação de tecnologias e de uma nova estruturação administrativa nas empresas que foram privatizadas e que agora, seriam controladas por grandes conglomerados econômicos nacionais e internacionais.

Também se intensificaram alguns destinos geográficos de investimento do capital privado, com pouca interferência da ação governamental sobre as desigualdades regionais. Essas grandes mudanças modelaram a ação estatal, saindo de cena um Estado empresário e emergindo um Estado regulador da economia. Notoriamente, em uns setores mais dom que em outros, como o setor de energia, um dos mais afetados por esta mudança.

Os arranjos produtivos petróleo e gás natural - do qual falaremos mais no próximo capítulo - vão ganhar especial impulso nesta conjuntura, com a criação da Agência Nacional do Petróleo (ANP) e o vislumbrar de grandes potencialidades de descoberta no território capixaba. Em 1998, 40\% das descobertas de petróleo e gás do país serão no Espírito Santo.

\subsubsection{Desestatização e descentralização dos setores elétricos dos anos 1990}

Este período de mudanças estruturais na economia, que vai de 1985 a 1997 , bem como a dívida acumulada pelo setor elétrico desde início da década de $1980^{219}$, determinaram a inviabilização econômico-financeira das empresas estatais de energia, afetando o marco institucional e a capacidade de atender às necessidades de aumento de geração. Um cenário de deterioração do setor elétrico brasileiro se somou à conjuntura política e às pressões internacionais pela reforma do Estado, dando força e voz aos defensores da solução desestatizante implantada durante a década.

Vale destacar, que é impossível dissociar a discussão da globalização da economia, mediante a internacionalização dos mercados de serviços, mercadorias e

\footnotetext{
${ }^{219}$ Que pode ser vista no gráfico 3.
} 
capitais, dos caminhos trilhados pelo setor elétrico brasileiro a partir de então. Mesmo que as influências do capital e das mudanças dos sistemas produtivos a nível nacional não sejam novidade para o setor, é nos anos 90 que se rompe o conceito clássico de fronteiras geográficas estatais, o que limita a atuação do Estado, principalmente sobre a execução das políticas cambiais, monetárias e tributárias.

Além disso, a fragmentação das atividades produtivas permite às empresas multinacionais praticar o comércio escolhendo seletivamente entre as distintas legislações nacionais e concentrando seus investimentos nos países onde elas lhes são mais favoráveis. Em um caminho paralelo, a disseminação do neoliberalismo, promovida especialmente por agências multilaterais como BID e FMI, com sua síntese relacionada ao Consenso de Washington, leva à liberalização do comércio e do investimento estrangeiro, à desregulamentação e à privatização em grande escala, como medidas a serem adotadas em países do capitalismo periférico, como o Brasil.

Luiz Carlos Bresser Pereira, Ministro da Administração Federal e Reforma do Estado de 1995 a 1998, argumenta em artigo, Uma reforma gerencial da Administração Pública no Brasil (1998), sobre as necessidades, naquele instante, de implementação de reformas no aparelho estatal, tidas como indispensáveis para que o Estado realizasse também o papel de garantidor dos direitos sociais e de promotor da competitividade econômica dentro deste cenário.

Com o nome de Reforma da Gerencial da Administração Pública, iniciada em 1995, foi definida inicialmente no Plano Diretor da Reforma do Aparelho de Estado, cuja emenda constitucional foi aprovada pelo Congresso Nacional naquele mesmo ano. Para Bresser Pereira esta reforma teve como objetivo atuar em quatro problemas do Estado Brasileiro: (1) a delimitação do tamanho do Estado, (2) a redefinição do papel regulador do Estado, (3) a recuperação da governança ou capacidade financeira e administrativa de implementar as decisões políticas tomadas pelo governo, e (4) aumento da governabilidade ou capacidade política do governo de intermediar interesses, garantir legitimidade e governar.

Além disso, entre as questões mais importantes que envolviam esta reforma, estavam: a criação de agências executivas e agências reguladoras, em que seriam inseridos dispositivos de consulta pública e audiências públicas como parte dos processos decisórios das agências, intitulado de controle social. Foram criadas também organizações sociais, a alteração do Regime Jurídico Único - que 
estabelecia, entre outras coisas, um regime trabalhista único para todos os servidores públicos - junto a uma nova política de recursos humanos. Consolidouse, assim, uma ideia de gestão pela qualidade total, como principal estratégia de gerenciamento a ser adotada pelas organizações do Estado.

O setor elétrico foi um dos primeiros a acompanhar estas mudanças no papel do Estado, antes, inclusive, das reformas propostas por Bresser Pereira. Através da reforma e de privatizações do setor no início da década de 1990, o Plano Nacional de Desestatização (PND), no Art. $1^{\circ}$ da Lei 8.031/90, previa justamente:

\begin{abstract}
“(i) transferir à iniciativa privada as atividades exploradas pelo setor público; (ii) reduzir a dívida pública; (iii) incentivar a "retomada de investimentos" a essas empresas privatizadas; (iv) modernizar as indústrias e ampliar sua competitividade; (v) focar a administração pública nas atividades que sua presença é fundamental; e (vi) fortalecer o mercado de capitais. Inclusive, a mesma Lei estabeleceu em seu Art. $4^{\circ}$, que as estatais seriam privatizadas mediante a: (i) transferência da participação societária por pulverização de ações junto ao público, empregados, acionistas, fornecedores e consumidores; (ii) abertura de capital; (iii) aumento de capital por meio de direitos de subscrição; (iv) transformação, incorporação, fusão ou cisão; (v) alienação, arrendamento, locação, comodato ou cessão de bens e instalações; ou (vi) dissolução de empresas ou desativação parcial de seus empreendimentos, com a consequente alienação de seus ativos". ${ }^{220}$
\end{abstract}

A reforma do setor de energia elétrica incluiu a privatização de concessionárias e a constituição de um marco regulatório. Contudo, não se conseguiu equacionar adequadamente a expansão dessa indústria, levando a uma crise do racionamento de 2001.

A privatização do setor foi marcada por uma forte desnacionalização, a partir da entrada de grandes grupos econômicos internacionais privados e estatais, atuantes em vários setores e países. Esta entrada de grupos estrangeiros também era esperada e estimulada pelo governo, dada a necessidade de divisas para ajudar no processo de ajuste macroeconômico.

Até 1995, a maioria das 62 companhias de geração, transmissão e distribuição era de propriedade federal ou dos governos estaduais. A Eletrobrás, como companhia centralizadora de energia de propriedade do governo federal, com uma participação minoritária de outros investidores, era a maior proprietária e operadora do setor de energia.

${ }^{220}$ BRASIL, 1990. 
Mas a Eletrobrás possuía, efetivamente, o controle da maioria das ações, de duas companhias de distribuição de eletricidade: a Espírito Santo Centrais Elétricas S/A (ESCELSA) e a Light - Serviços de Eletricidade S/A, do Estado do Rio de Janeiro, sendo os governos estaduais, donos da maioria das outras companhias de distribuição. Na tabela 3, podemos ver o resultado dos leilões realizados de 1995 a 2000:

Tabela 3 - Resultados dos leilões de privatização do setor elétrico (1995-2000)

\begin{tabular}{|c|c|c|c|c|c|}
\hline EMPRESA & $\begin{array}{c}\text { DATA } \\
\text { DA } \\
\text { VENDA }\end{array}$ & $\begin{array}{c}\text { VALOR DA } \\
\text { LICITAÇÃO } \\
\text { (US\$ } \\
\text { MILHÕES) }\end{array}$ & ÁGIO & $\begin{array}{c}\% \text { DO } \\
\text { CAPITAL }\end{array}$ & $\begin{array}{c}\text { GRUPO } \\
\text { COMPRADOR }\end{array}$ \\
\hline Escelsa & $12 / 07 / 95$ & 385 & 11,78 & 50,00 & $\begin{array}{l}\text { Iven e GTD } \\
\text { (Brasil) }\end{array}$ \\
\hline Light & $21 / 05 / 96$ & 2.217 & - & 50,44 & $\begin{array}{c}\text { EDF (França), } \\
\text { AES (EUA) e } \\
\text { Houston }\end{array}$ \\
\hline Cerj & $20 / 11 / 96$ & 588 & 30,27 & 70,26 & $\begin{array}{c}\text { Clilectra/Enersis } \\
\text { (Chile) e EDP } \\
\text { (Portugal) }\end{array}$ \\
\hline Coelba & $01 / 07 / 96$ & 1.602 & 77,38 & 62,54 & $\begin{array}{c}\text { Iberdrola } \\
\text { (Espanha) e Previ } \\
\text { (Brasil) }\end{array}$ \\
\hline $\begin{array}{c}\text { CEEE } \\
\text { (COeste) }\end{array}$ & $01 / 10 / 97$ & 1.372 & 93,55 & 90,91 & AES (EUA) \\
\hline $\begin{array}{l}\text { CEEE (Norte- } \\
\text { NE) }\end{array}$ & $21 / 10 / 97$ & 1.487 & 82,62 & 90,75 & $\begin{array}{l}\text { VBC (Brasil), } \\
\text { CEA (EUA) e } \\
\text { Previ (Brasil) }\end{array}$ \\
\hline CPFL & $01 / 11 / 97$ & 2.741 & 70,15 & 41,06 & $\begin{array}{c}\text { VBC (Brasil) e } \\
\text { Bonnaire (Brasil) }\end{array}$ \\
\hline Enersul & $19 / 11 / 97$ & 568 & 83,79 & 48,67 & Escelsa \\
\hline Cemat & $27 / 11 / 97$ & 356 & 21,09 & 86,91 & $\begin{array}{c}\text { Grupo Rede/Inepar } \\
\text { (Brasil) }\end{array}$ \\
\hline
\end{tabular}




\begin{tabular}{|c|c|c|c|c|c|}
\hline Energipe & $01 / 12 / 97$ & 525 & 96,05 & 86,42 & $\begin{array}{c}\text { Cataguases- } \\
\text { Leopoldina } \\
\text { (Brasil)/ CMS } \\
\text { (EUA) }\end{array}$ \\
\hline Cosern & $01 / 12 / 97$ & 616 & 73,90 & 85,75 & $\begin{array}{c}\text { Iberbrola } \\
\text { (Espanha) Previ } \\
\text { (Brasil) }\end{array}$ \\
\hline Coelce & $02 / 04 / 98$ & 868 & 27,20 & 53,11 & $\begin{array}{l}\text { Enersis (Chile) e } \\
\text { Endesa (Espanha) }\end{array}$ \\
\hline $\begin{array}{c}\text { Eletropaulo } \\
\text { Metropolitana }\end{array}$ & $15 / 04 / 98$ & 1.776 & - & 29,80 & EDF/AES/Houston \\
\hline Celpa & $01 / 07 / 98$ & 388 & - & 51,26 & $\begin{array}{c}\text { Grupo Rede/Inepar } \\
\text { (Brasil) }\end{array}$ \\
\hline Elektro & $16 / 07 / 98$ & 1.273 & 98,90 & 46,62 & $\begin{array}{c}\text { Enron Brasil } \\
\text { Power Holding }\end{array}$ \\
\hline $\begin{array}{l}\text { Eletropaulo } \\
\text { Bandeirante }\end{array}$ & $17 / 09 / 98$ & 860 & - & 29,80 & CPFL/EDP \\
\hline $\begin{array}{l}\text { Celb-Cia. } \\
\text { Em BORB. }\end{array}$ & $30 / 11 / 99$ & 45 & - & 75,26 & Energipe \\
\hline Celpe & $17 / 02 / 00$ & 1.004 & - & 99,56 & $\begin{array}{c}\text { ADL Energy } \\
\text { (Iberdrola), Previ e } \\
\text { BB - Banco de } \\
\text { Investimento }\end{array}$ \\
\hline Cemar & $15 / 06 / 00$ & 289 & - & 86,25 & $\begin{array}{c}\text { Pensylvannia } \\
\text { Power \& Light }\end{array}$ \\
\hline SAELPA & $30 / 11 / 00$ & 185 & - & 74,29 & Energipe \\
\hline Geração & & & & & \\
\hline $\begin{array}{l}\text { Cachoeira } \\
\text { Dourada }\end{array}$ & $05 / 09 / 96$ & 663 & 43,49 & 78,88 & Endesa/Enersis \\
\hline Gerasul & $15 / 09 / 96$ & 801 & - & 42,10 & Tractebel (Bélgica) \\
\hline $\begin{array}{c}\text { Cesp } \\
\text { Paranapanema }\end{array}$ & $28 / 07 / 99$ & 682 & 90,2 & 38,66 & $\begin{array}{c}\text { Duke Energia do } \\
\text { Sudeste Ltda }\end{array}$ \\
\hline Cesp Tietê & $27 / 10 / 99$ & 472 & 29,3 & 38,66 & AES Gerasul \\
\hline $\begin{array}{c}\text { Outras } \\
\text { Operações }\end{array}$ & & 3.284 & & & \\
\hline
\end{tabular}




\begin{tabular}{|c|c|c|c|c|l|}
\hline $\begin{array}{c}\text { Empresas } \\
\text { Federais }\end{array}$ & & 3.403 & & & \\
\hline $\begin{array}{c}\text { Empresas } \\
\text { Estaduais }\end{array}$ & & 18.358 & & & \\
\hline
\end{tabular}

Fonte: tabela construída com dados extraídos da ANEEL e de LANDI (2006).

O resultado desta Reforma do Setor Elétrico Brasileiro foi a organização de toda uma estrutura descentralizada. Criou-se uma estrutura regulatória composta pela Agência Nacional de Energia Elétrica (ANEEL), organismo regulador e fiscalizador, cujo objetivo seria disciplinar as tarefas do setor elétrico por intermédio de resoluções - e por duas entidades de direito privado, ligadas aos agentes concessionários da indústria de eletricidade. Uma delas foi o Operador Nacional do Sistema (ONS), que criou e ampliou regras e normas para gerenciar a produção e a transmissão de eletricidade.

Já a outra foi o Mercado Atacadista de Energia Elétrica (MAE), que formou um conjunto de regras comerciais para os agentes ou concessionárias que negociam a energia por atacado. Por essas regras, deveriam ser registradas as quantidades negociadas nos contratos de longo prazo e determinados os preços de venda a curto prazo - chamado de spot - da energia elétrica ${ }^{221}$.

Além disso, em 1999 foi criado o Comitê Coordenador do Planejamento da Expansão do Sistema Elétrico (CCPE), com o objetivo de regular e estruturar a atividade de planejamento da expansão elétrica. No ano seguinte, foi regulamentado o Conselho Nacional de Política Energética (CNPE), órgão de assessoramento, ligado à presidência da República, que tinha como objetivo a formulação de políticas e diretrizes ligadas à energia.

As reformas brasileiras também impactaram as cadeias produtivas industriais, que enfatizaram ganhos de produtividade pela diminuição da quantidade de trabalho, através de demissões, terceirização e importação de soluções tecnológicas advindas do exterior. O resultado prático dessa política atingiu no longo prazo as contas públicas, pela ampliação de importações e das remessas de lucros e dividendos.

Estas políticas empresariais, efetivadas por incentivo ou fomento do Estado nacional, modificaram profundamente a lógica de reprodução da indústria de

${ }^{221}$ GOLDENBERG e PRADO, 2003. 
energia elétrica. Dentre os resultados, houve um aumento desproporcional na lucratividade das empresas concessionárias, em um primeiro momento, e impactos negativos sobre os setores da economia e sobre as regiões da federação.

Outra questão relevante é que o poder econômico e a capacidade gerencial desses grupos privados entrantes passaram a contrastar com a fragilidade dos órgãos de controle e regulação a nível nacional e, principalmente, local. As transformações impostas ao sistema elétrico brasileiro significaram um movimento de modificação dos papéis e funções mediante a utilização intensiva de descentralização, cortes e reduções funcionais ${ }^{222}$. Uma outra questão refere-se, à ação política do capital privado no Congresso, que viria a assumir importância crescente ao longo do primeiro mandato de Fernando Henrique Cardoso. Neste período de reformas, com abertura para o mercado, a estrutura de representação de interesses do empresariado industrial se articulava de forma complexa e diferenciada ${ }^{223}$ em relação a outros momentos da história brasileira.

No caso do setor elétrico, esta dinâmica ajudou no consenso de que, com a abertura do mercado, seria necessária a criação de um mercado competitivo no atacado, com importância para o livre acesso à transmissão, incremento da produção independente, desverticalização e descentralização do setor.

Seguindo estes passos, a coordenação operacional passou a ser feita pelo Operador Nacional do Sistema (ONS) com base na regulamentação do Grupo Coordenado de Operação Integrada (GCOI), da mesma forma que o Mercado Atacadista de Energia (MAE). No âmbito institucional federal, as atribuições foram distribuídas entre o Ministério das Minas e Energia e a agência reguladora ANEEL. Para Helena Lorenzo (2002), essas atribuições não foram claras quanto aos seus limites, dando margem a disputas entre essas instâncias e os órgãos coordenadores privados.

\subsubsection{O papel das agências reguladoras}

Neste horizonte, é relevante o papel da Agência Nacional de Energia Elétrica (ANEEL). Esta esteve no centro da descentralização das atividades de 
regulação, fiscalização e controle junto às agências reguladoras estaduais, através de negociação entre governos estaduais, bancadas federais dos estados e a União.

A sua criação foi acompanhada da constituição de várias outras agências na esfera regional. Entre 1997 e 2005 foram criadas 23 agências em 18 estados, além de duas agências municipais ${ }^{224}$. A descentralização do modelo de agências está diretamente relacionada ao avanço das privatizações e ao forte estímulo do governo federal à regulação. Assim, papel da União, como agente indutor da difusão da nova forma institucional, foi fundamental, sobretudo, na conformação do incentivo e do financiamento das privatizações, além de influenciar os programas estaduais de reforma do setor público.

Mesmo com os estados enfraquecidos devido à crise de endividamento público e à situação deficitária das empresas de energia, o que delineou essa condição foi a importância dos setores elétricos estaduais para o sistema elétrico nacional, tendo em vista que a distribuição de energia elétrica estava em sua maioria sob controle estadual, por meio de empresas estaduais de energia estatais. As empresas estaduais, antes da privatização, controlavam cerca de $80 \%$ da distribuição de energia elétrica. Assim, o governo federal também teve que ceder a descentralização do poder de regular e fiscalizar para viabilizar as privatizações nos estados.

Fica claro, tendo em vista todo o cenário político, econômico e fiscal da época, que os estados tinham interesse em privatizar suas companhias de energia, mas também pretendiam manter o máximo possível de controle sobre o setor. No caso de São Paulo, por exemplo, foram criados programas de desestatização e órgãos parecidos com as agências reguladoras estaduais, para coordenar a privatização tanto no setor elétrico quanto no de gás natural.

Assim, um dos interesses dos estados federados na criação da ANEEL era assegurar a manutenção do poder que os estados exerciam sobre a distribuição dos serviços de energia através das empresas estaduais de energia elétrica. ${ }^{225}$ Neste

\footnotetext{
${ }^{224}$ Todas as duas na área de saneamento. Uma em Joinville, Santa Catarina, e outra em Cachoeiro de Itapemirim, no Espírito Santo.

${ }^{225}$ Interessante aqui estender um debate teórico sobre o papel das agências reguladoras. Nas análises de Regina Farias (2006), as agências reguladoras, que foram fruto das reformas administrativas da década de 1990, são consideradas na estrutura estatal como entes neutros que, teoricamente, fazem a intermediação entre os consumidores e as empresas de energia. Contudo, Nicos Poulantzas (1978) nos fornece uma primeira análise sobre a função destas instituições, a partir de sua observação sobre o poder estatal. Para Poulantzas, os aparelhos do Estado não têm "poder" por si mesmos. No
} 
caminho, o Projeto de Lei original no $1.669 / 96$ propunha a criação da ANEEL e do Conselho de Serviço Público de Energia. Especificamente no seu art. $3^{\circ}$, previa a articulação da União com os estados ${ }^{226}$ para a exploração de serviços e instalações de energia elétrica, o aproveitamento energético dos cursos de água, além da possibilidade de credenciamento de órgãos estaduais para realizarem as atividades de fiscalização e controle dos serviços prestados nos seus territórios.

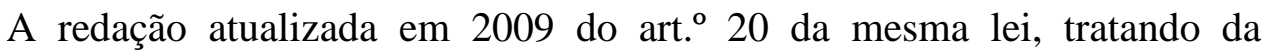
descentralização das atividades, diz:

"Art. 20. Sem prejuízo do disposto na alínea b do inciso XII do art. 21 e no inciso XI do art. 23 da Constituição Federal, a execução das atividades complementares de regulação, controle e fiscalização dos serviços e instalações de energia elétrica poderá ser descentralizada pela União para os Estados e para o Distrito Federal visando à gestão associada de serviços públicos, mediante convênio de cooperação."

Ainda continuam excluídos da descentralização os serviços e instalações de geração de interesses do sistema elétrico interligado e os de transmissão integrante da rede básica. Mas é importante dizer que nenhuma outra agência federal teve um nível de descentralização de atividades semelhante ao da ANEEL, não decorrendo apenas de racionalidade técnica, mas, sobretudo, devendo-se à articulação política exercida pelos estados em torno do interesse de manter o controle sobre a regulação e a fiscalização dos serviços de energia elétrica ${ }^{227}$.

Podemos dizer que o papel ANEEL, enquanto instituição fruto de um longo caminho de privatizações, mais especialmente de um longo processo de modernização estatal brasileiro, é tanto resultado, quanto acessório da disputa pelo poder nos entes federados. Resultado enquanto instituição criada para organização de um outro lugar no qual o Estado irá ocupar um papel central ao longo das

\footnotetext{
processo contrário, este é um lugar que materializa e concentra as relações de classe. O Estado não é uma entidade, com uma essência instrumental intrínseca, mas é uma relação, mais precisamente a condensação de relações. O autor desenvolve o conceito da separação das esferas política e econômica através do Estado. O poder político, embora apoiado no poder econômico, é proprietário no sentido de que, em sua transformação condiciona, toda mudança em outras áreas de poder e o poder político se concentram e se materializam no Estado - o ponto central do exercício do poder político. Sob esta análise, localiza-se o papel da agência, fortemente relacionada com o ambiente político em que ela opera. Existe uma correspondência entre os traços contextuais e as características internas da burocracia. Como principais características do contexto brasileiro temos: a debilidade das instituições; o baixo nível de organização da sociedade civil; o baixo nível de expectativa quanto à atuação do governo; o baixo nível de participação; o povo como objeto da política pública 226 Artigo revogado em 2004.

${ }^{227}$ Até março de 2019, 10 dos 24 estados e suas respectivas agências, tinham convênios com a Aneel em seu relatório online sobre a descentralização. Ver mais em https://www.aneel.gov.br/descentralizacao-de-atividades. Acessado em 24 de julho de 2020.
} 
reformas. E acessório, pois é um espaço político em que se disputa o controle do planejamento, desenvolvimento e participação econômica e política na indústria do setor elétrico.

5.1.3 A importância da privatização da ESCELSA em um novo paradigma energético capixaba.

Nesse cenário de desestatização e de mudanças profundas, a Espírito Santo Centrais Elétricas S/A foi incluída no Plano Nacional de Desestatização (PND) pelo Decreto 572, em junho de 1992, sendo a primeira empresa a ser leiloada.

A ESCELSA era uma sociedade anônima de capital fechado controlada pela Eletrobrás, que detinha 72,337\% das ações e com participação do Governo Estadual com 23,176\%, de Prefeituras 2,298\%, e de outros acionistas com os restantes $2,189 \%^{228}$. Era garantido, especialmente ao estado do Espírito Santo, por dispositivo estatutário, a indicação de um dos seus quatro diretores e, caso sua participação atingisse $30 \%$, de dois diretores. Assim, mesmo minoritário, o Governo Estadual poderia ter algum tipo de influência na estratégia da empresa.

É no governo de Albuíno Azeredo (PDT) que se dá o primeiro passo para a total privatização da Espírito Santo Centrais Elétricas S/A, quando é enviado à Assembleia Legislativa do estado, em 24 de fevereiro de 1994, através da mensagem 13-94, o projeto de lei 19/94. O projeto tem em seu artigo $1^{\circ}$ a autorização à alienação de 1.054.072 (um milhão cinquenta e quatro mil e setenta e duas) ações ou 23,17\% do total de ações da ESCELSA ${ }^{229}$.

O envio do projeto de alienação das ações da ESCELSA de longe foi um processo pacífico. Sua venda suscitou pesados debates públicos entre as elites políticas capixabas e nacionais. E isso se deu ao fato da empresa de energia do Espírito Santo ter sido a primeira distribuidora regional a ser privatizada, transformando o debate em torno de sua privatização em um debate em torno do modelo de privatização nacional que se colocava.

Dentro desta conjuntura, Albuíno escreve ao então deputado e líder do PSDB na Câmara dos deputados, José Serra, afirmando sua posição em relação à privatização,

${ }^{228}$ ROSA e HOFFMAN, 1995, p. 01.

${ }^{229}$ RIZI, 2008, p. 45 
[...] somos contra a privatização de empresas que operam em setores estratégicos e, em consequência, acionamos todos os mecanismos ao nosso alcance para evitar que fosse privatizada a Escelsa. Apesar de nosso pensamento, acatamos respeitosamente a decisão do Governo Federal, que resolveu de forma irreversível promover a privatização da Escelsa $^{230}$.

Já o prefeito de Vitória, Paulo Hartung, também do $\mathrm{PSDB}^{231}$, demonstra preocupação com os desdobramentos que poderiam ocorrer no processo. Hartung levanta alguns pontos, dos quais destacamos:

“[...] Os investimentos realizados permitiram o desenvolvimento socioeconômico do Espírito Santo, fazendo destacar-se, a nível nacional, como Estado possuidor de um dos maiores índices de eletrificação rural; [...], porém, o realizado no passado não esgotou a responsabilidade que temos, como poder público, em garantir e evoluir esse nível de desenvolvimento. Para tal, é a energia o fator fundamental e essencial, e é a Escelsa a única via de suprimento de energia elétrica para o Espírito Santo."232

Neste ínterim, o governador Albuíno Azeredo (PDT) demonstra seu desagrado ao comportamento do prefeito de Vitória e de lideranças do PSDB no estado, que se articulavam para condenar e tentar obstruir a votação sobre a venda das ações, além da própria privatização da empresa, na Assembleia Legislativa do Espírito Santo.

Significativo destacar a problemática da composição da Assembleia Legislativa capixaba neste momento. A composição da casa, aliada ao padrão de comportamento dos atores políticos da época, indicava as restrições que estavam sujeitas as organizações do aparato do Estado para articular, definir e implementar políticas que pudessem mudar seu trajeto econômico. Instauraram-se, assim, no Espírito Santo, ao mesmo tempo que um imbróglio a nível nacional a respeito do processo de desestatização dá ESCELSA, uma complexa situação de governabilidade. Nas palavras de Pereira (2002),

“[...] a esmagadora maioria [dos deputados] sempre teve carreira dominante anterior ao exercício do mandato vinculada ao Estado - do regime militar -. Só esse resultado já é suficiente para demonstrar que os índices altos de renovação não traziam para o legislativo parlamentares com perfis de carreiras muito diferentes. Os nomes mudavam, mas o histórico pessoal de atuação política era sempre muito parecido [...]. A maioria dos deputados que tiveram carreiras vinculadas ao Estado sempre contou com bases eleitorais interioranas. Exatamente

${ }^{230}$ ESPÍRITO SANTO (Estado). Of./G n 0 0343/94, 16 de março de 1994.

${ }^{231}$ Falaremos dele mais adiante, mas é relevante dizer que Hartung foi um importante figura da política capixaba, com forte relação com a antiga ala do PSD capixaba, ligada ao projeto de desenvolvimento de Jones dos Santos Neves do antigo (PSD). Ele que ocuparia a cadeira de governador por três vezes a partir de 2003.

232 PREFEITURA MUNICIPAL DE VITÓRIA. GAB/82/93-Circ., 28 de fevereiro de 1994. 
a metade do plenário em 90 e 94, subindo para 56,7\% em 98". (PEREIRA, 2002, p. 22).

Mesmo neste teatro político conturbado, em 6 de abril de 1994 a Assembleia Legislativa, após uma agitada sessão de 18 horas, aprova o projeto que deu origem à Lei 4.895 para a venda das ações da ESCELSA em poder do governo do estado. Estavam presentes na sessão, em sua maioria, membros do sindicato dos funcionários e membros da sociedade civil organizada, expulsos pela tropa de choque da Polícia Militar do plenário, após o deputado Cabo Camata (PSB) ter chamado os manifestantes de "cambada de vagabundos" 233 . Foram 18 votos a favor e 9 nove contra a venda. Albuíno classificou o resultado como uma "vitória da sociedade capixaba"234.

Em 1995, ano do seu leilão de privatização na bolsa de valores do Rio de Janeiro, a capacidade instalada da ESCELSA era de cerca de 160 MW, correspondendo a $24 \%$ das necessidades do mercado interno. O restante era importado do sistema nacional ${ }^{235}$, abastecido por FURNAS e ITAIPU BINACIONAL ${ }^{236}$, estrutura que não se altera de forma substancial até a crise elétrica de 2001. Sendo a estrutura de consumo de energia naquele momento a seguinte:

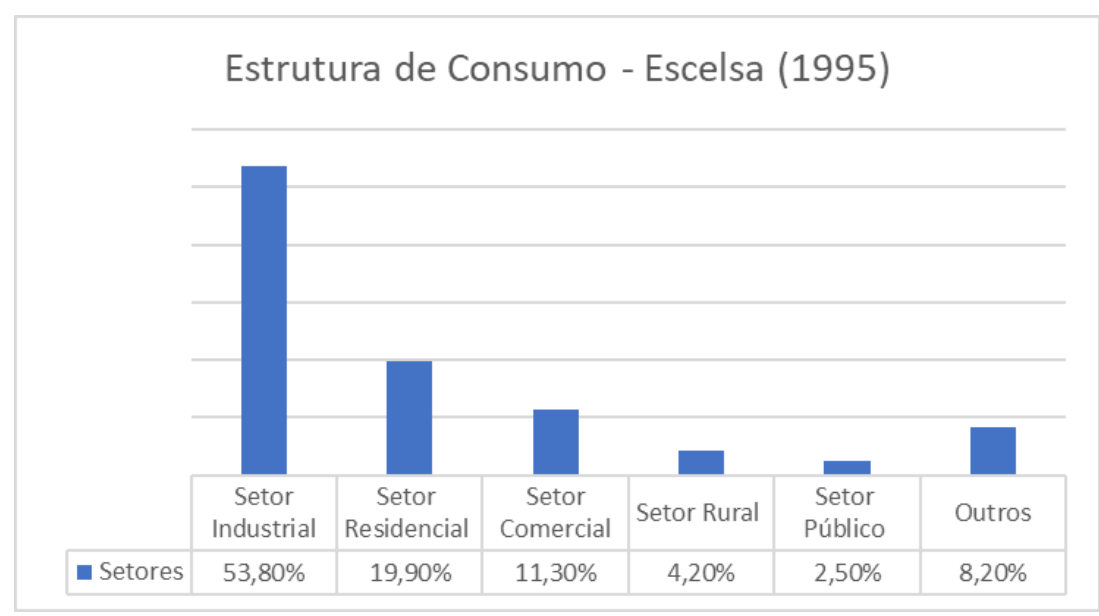

Gráfico 4 - Fonte: ROSA e HOFFMAN (1995)

\footnotetext{
${ }^{233}$ RIZI, 2008, p. 43 e 45.

${ }^{234}$ Assembleia aprova a venda das ações da Escelsa. A Gazeta, Vitória, p. 4, 7 abr. 1994.

${ }^{235}$ Situação que persiste até hoje, como discutiremos mais adiante.

${ }^{236}$ Com uma rede de transmissão, ESCELSA compõe-se neste momento de 29,2 mil Km que se interliga com o Sistema Sul-Sudeste em um tronco de FURNAS e outra linha com a CEMIG.
} 


\section{CAPÍtulo 6 - DA CRISE AO PARAdOXO ATUAL: ENTRE UM PROJETO DE DESENVOLVIMENTO ECONÔMICO E A GERAÇÃO DE ENERGIA ELETRICA RENOVAVEL.}

\subsection{O período pós-1990 e o continuidade na alternância entre Paulo Hartung e Renato Casagrande}

O capítulo que fecha esta pesquisa, buscará apontar para as repercussões do processo histórico de formação do setor de energia elétrica capixaba. Duas questões são destaques: a primeira, a cooptação permanente dos grupos políticos locais para o projeto de desenvolvimento econômico nacional. E segundo, a influência direta deste modelo de desenvolvimento na conformação de um composto de geração de eletricidade no Estado do Espírito Santo proveniente de termoelétricas.

Dentro destes aspectos se nota primeiramente, que mesmo que o Estado nunca tenha deixado de participar da conformação do setor elétrico nacional e capixaba, podemos dizer que a privatização da ESCELSA pode ser considerada um eixo de mudança na ação estatal sobre o setor elétrico do Espírito Santo, à medida que o direcionamento do investimento privado a partir da abertura de mercado nacional de energia nos anos 1990 se torna mais um fator a determinar as características do setor - mesmo que a visão das elites políticas locais sobre o desenvolvimento econômico ainda seja relevante para delimitar o planejamento da expansão da infraestrutura.

Entretanto, estas transformações não foram capazes de alterar as configurações de geração interna de energia constituídas desde 1950, relacionadas a um projeto de desenvolvimento econômico eletrointensivo. Inclusive, estas relações foram substancialmente acentuadas por dois fatores: (1) primeiro, pela necessidade de investimento das empresas em produção interna de eletricidade no estado, sendo adotada a construção de termoelétricas e a autoprodução privada como principais motores da expansão da oferta interna, e depois, (2) pela retomada do planejamento desenvolvimentista estatal nacional em solo capixaba, na gestão federal do Partido dos Trabalhadores (PT).

Sob estas condições, entre 2003 e 2020, o Espírito Santo esteve o comando de dois governadores: Paulo Hartung (PSB e depois PMDB), de 2003 a 2007, 2007 
a 2011 e 2015 e 2019, e Renato Casagrande (PSB), de 2011 a 2015 e a partir de $2019^{237}$.

No período destes dois mandatos, as diretrizes do slogan "um novo Espírito Santo" forjado no primeiro governo da gestão de Paulo Hartung e alicerçado nos dados e nas expectativas de progresso econômico nacional. O slogan foi mantido como princípio de ação da administração estadual, sendo a concepção norteadora das relações entre governo estadual e as representações dos grupos políticos e econômicos locais.

Assim, identificou-se mais a Paulo Hartung do que a Renato Casagrande ${ }^{238}$ um vínculo com um modelo de desenvolvimento que tem produção histórica sobre

${ }^{237}$ Paulo Cesar Hartung Gomes. Economista formado pela Universidade Federal do Espírito Santo (UFES), presidente do Diretório Central dos Estudantes da UFES de 1978 a 1979. Filiado ao Movimento Democrático Brasileiro (MDB), em abril de 1964. No fim da década de 1970, participou do Comitê Brasileiro de Anistia (CBA) no Espírito Santo e em 1979 filiou-se ao Partido do Movimento Democrático Brasileiro (PMDB). Nessa legenda, foi eleito deputado estadual no pleito de novembro de 1982, assumindo o mandato na Assembleia Legislativa do Espírito Santo em março do ano seguinte. Em 1985, foi um dos delegados do Espírito Santo ao Colégio Eleitoral que elegeu o sucessor do presidente da República, general João Batista Figueiredo. Paulo Hartung elegeu-se deputado estadual constituinte em novembro de 1986, sempre na legenda do PMDB. Em 1989, passou a participar da Comissão Constitucional da Assembleia Estadual Constituinte do Espírito Santo, chegando a ocupar a posição de líder da bancada do PSDB de 1990 a 1991, que havia recém se filiado. Em outubro de 1990, foi eleito deputado federal pelo PSDB. Contudo, renunciou ao mandato de deputado em $1^{\circ}$ de janeiro de 1993 para receber a prefeitura do seu antecessor Vítor Buaiz, do Partido dos Trabalhadores (PT). Em junho de 1997, Paulo Hartung assumiu o cargo de diretor de desenvolvimento regional e social do Banco Nacional do Desenvolvimento Econômico e Social (BNDES), por indicação do ministro das Comunicações, Sérgio Mota, onde permaneceu até março de 1998. Paulo Hartung assumiu sua cadeira no Senado em fevereiro de 1999. Em outubro de 2001, já pensando nas eleições seguintes para o governo do Espírito Santo, transferiu-se para o Partido Socialista Brasileiro (PSB), e em outubro de 2002 foi eleito, ainda no primeiro turno, governador do estado. CPDOC (FGV). Dicionário Histórico-Biográfico Brasileiro On-line: Paulo Cesar Hartung Gomes. Rio de Janeiro, 04 dez. 2020. Disponível em: http://www.fgv.br/cpdoc/acervo/dicionarios/verbete-biografico/paulo-cesar-hartung-gomes.

Renato Casagrande. Ingressou na vida política como militante do Partido Comunista do Brasil (PC do B) e como dirigente do Centro Acadêmico da Universidade Federal de Viçosa, instituição na qual ingressou em 1979 como aluno do curso de graduação em engenharia florestal. Em 1982, filiou-se ao Partido do Movimento Democrático Brasileiro (PMDB). Entre 1984 e 1987 atuou como secretário de Obras e Serviços Públicos da Prefeitura Municipal de Castelo. Em 1987, filiou-se ao Partido Socialista Brasileiro (PSB) e ingressou na Faculdade de Direito de Cachoeiro de Itapemirim (ES). No pleito de 1990, elegeu-se o primeiro deputado estadual da história do PSB capixaba. Em 1995 foi vice-governador na chama com Vitor Buais (PT). Em 1999 foi convidado para o cargo de Secretário de Meio Ambiente do município de Serra, região metropolitana da Grande Vitória. No ano seguinte, foi escolhido Secretário-Geral da Comissão Executiva Nacional do PSB. No pleito de 2002, candidatou-se ao cargo de deputado federal e foi eleito com 69.721 votos. Em outubro foi eleito senador federal pelo Espírito Santo, com 1.031 .487 votos, número correspondente a 62,39\% dos votos válidos. Em 2003 foi eleito Deputado e em 2007 Senador. 2011, foi eleito Governador do Espírito Santo e desde 2019 é governador.

${ }^{238}$ É importante notar, contudo, que durante a pesquisa foi possível identificar mais matérias dos principais jornais capixabas favoráveis às ações de Hartung do que a conduta de Casagrande. No nosso entendimento, isso se deve ao momento mais favorável em termos de articulação política e econômica com os vários setores capixabas, de um em relação ao outro. $\mathrm{O}$ que criou uma 
o itinerário republicano capixaba, especialmente, aquele iniciado pelo governo Jones dos Santos Neves. Ao que nos parece, esta condição também tem relação com os nortes econômicos dos primeiros anos da gestão federal liderada por Luís Ignácio Lula da Silva (PT) entre 2003 e 2011, que se alia ao estabelecimento de uma proximidade pessoal entre o governador Hartung e o presidente Lula da Silva, a ponto de Lula influenciar a decisão de Paulo Hartung em trocar o PSB pelo $\mathrm{PMDB}^{239}$.

Neste ínterim, o projeto viabilizado ao longo dos dois primeiros mandatos de Hartung e consolidado na sequência por Casagrande, foi o momento em que o estado recebeu, proporcionalmente, um dos maiores índices de investimento público e privado da federação. Segundo dados do Instituto Jones dos Santos Neves (2012), entre 2008 e 2020, a economia capixaba recebeu investimentos de $\mathrm{R} \$ 143,1$ bilhões, em que o setor de energia significou anualmente, em média, 11,84\% dos recursos totais do período ${ }^{240}$.

Os investimentos que foram concluídos no setor de energia, em sua maioria, estão relacionados a projetos em transmissão e distribuição de energia elétrica no Estado, mas também cabe apontar para o investimento na exploração de petróleo e gás natural, inseridos no contexto de expansão da indústria extrativista.

A indústria extrativa capixaba é um dos ramos que se desenvolve desde os anos 60, e que reúne as atividades de extração de minerais metálicos, de petróleo e gás natural, de minerais não-metálicos e de carvão mineral. A extração de minerais metálicos, o de petróleo e gás e o de minerais não metálicos responderam, em 2005, a $28,6 \%, 8,4 \%$ e 5,2\%, respectivamente, do Valor da Transformação Industrial $(\mathrm{VTI})^{241}$ do estado. Sobre a indústria de extração de minerais metálicos, o Espírito

proximidade maior de Paulo Hartung com ideário jonista, alicerçado pelas principais elites desenvolvimentistas capixabas, que por sua vez, são proprietárias dos dois maiores jornais de circulação do estado, "A Tribuna" e "A Gazeta".

${ }^{239}$ Vale destacar a manchete do jornal A Gazeta: "Hartung deve seguir conselho de Lula e confirmar filiação no PMDB. Futuro partidário do governador foi discutido em encontro com o presidente.” A Gazeta, Vitória, ES, 09/02/2005, p.14, c.1-6.

${ }^{240}$ Instituto Jones dos Santos Neves (IJSN). Investimentos Concluídos no Espírito Santo, 2008$2011 ; 2012 ; 2013 ; 2014 ; 2015-2020$.

${ }^{241} \mathrm{O}$ Valor da Transformação Industrial (VTI) corresponde à diferença entre o valor bruto da produção industrial (VBPI), isto é, a soma das vendas de produtos e serviços industriais (receita líquida industrial), variação dos estoques dos produtos acabados e em elaboração, e produção própria realizada para o ativo imobilizado e o custo com as operações industriais (COI), sendo estes os custos ligados diretamente à produção industrial, ou seja, é o resultado da soma do consumo de matérias-primas, materiais auxiliares e componentes, da compra de energia elétrica, do consumo de combustíveis e peças e acessórios; e dos serviços industriais e de manutenção e reparação de 
Santo sedia hoje duas empresas que são destaques nacionais, e que são originárias dos Grandes Projetos (GP's): a Companhia Vale do Rio Doce (hoje Vale) e a Samarco Mineração.

A respeito da Vale, - privatizada em maio de 1997 quando o Consórcio Brasil adquiriu 41,73\% das ações ordinárias do governo federal - as atividades da empresa no Espírito Santo compreendem: sete usinas de pelotização de minério de ferro, com uma capacidade de produção de 25 milhões de toneladas de pelotas/ano, um Complexo Portuário de Tubarão, localizado em Vitória, um Terminal Portuário de Vila Velha, localizado no Porto de Capuaba, Vila Velha, a Estrada de Ferro Vitória a Minas (EFVM), a Ferrovia Centro-Atlântica (FCA) e o Terminal Rodoferroviário de Colatina.

A Samarco, por sua vez, produzia até antes da tragédia de Mariana ${ }^{242}$, anualmente, 14 milhões de toneladas de pelotas de minério de ferro e cerca de 1 milhão de toneladas de finos de minério concentrado em Ubu - município capixaba de Anchieta - onde existe um complexo portuário. A partir de 2008, com a entrada em operação da terceira usina de pelotização, a empresa teve sua capacidade produtiva aumentada em 54\% (21,6 milhões de toneladas). Além disso, sua participação no mercado mundial passaria de 15\% para 19\%, segundo informação do Relatório Anual 2006 da empresa ${ }^{243}$.

A respeito da indústria metalúrgica capixaba, o destaque fica por conta da hoje chamada ArcelorMittal Tubarão, antiga estatal Companhia Siderúrgica de Tubarão (CST), que representou 27,2\% do VTI estadual em 2005. Após a sua privatização em 1992, a companhia diversificou sua produção, em 2002, com a implantação de um Laminador de Tiras a Quente (LTQ). Já em 2003, teve início o Plano de Expansão da produção para 7,5 milhões de toneladas por ano, que foi concluído em 2007.

Ainda em 2005, foi criada a Arcelor Brasil, resultado da união da Companhia Siderúrgica Belgo Mineira, da CST e da Vega do Sul, todas sob

\footnotetext{
máquinas e equipamentos ligados à produção prestados por terceiros. NESCAT/UFSC. Disponível em: https://necat.ufsc.br/valor-de-transformacao-industrial-ibge/. Acessado em 08 dez. 2020.

${ }^{242}$ Há 3 anos, o rompimento de barragem de Mariana causou maior desastre ambiental do país e matou 19 pessoas. Portal G1. Disponível em: https://g1.globo.com/mg/minasgerais/noticia/2019/01/25/ha-3-anos-rompimento-de-barragem-de-mariana-causou-maior-desastreambiental-do-pais-e-matou-19-pessoas.ghtml Acessado em: 08 dez. 2020.

${ }^{243}$ Disponível em: https://www.samarco.com/wp-content/uploads/2016/08/2006-Relatorio-Anualde-Sustentabilidade.pdf Acessado em: 08 dez. 2020.
} 
controle acionário da Arcelor, empresa de capital luxemburguês. Em 2006, a Arcelor Brasil e suas subsidiárias passaram a fazer parte do grupo ArcelorMittal, como consequência da fusão entre a Arcelor e a Mittal Steel.

Para se ter uma ideia da importância dessas empresas, em um ranking das 200 Maiores do Espírito Santo, desenvolvido pelo Instituto Euvaldo Lodi (IEL) instituto ligado a Federação das Indústrias do Espírito Santo (FINDES) respectivamente, Vale (CVRD), ArcelorMittal Tubarão, Aracruz Celulose e Samarco foram as quatro maiores empresas do estado em 2008, com Receita Operacional Bruta (ROB) gerada localmente superior a R \$ 23,2 bilhões, representando mais de $60 \%$ do total de ROB das empresas atuantes no estado.

Outro modo de se analisar o peso das grandes empresas eletrointensivas na indústria local é a participação delas nas exportações capixabas. Os dados do Ministério do Desenvolvimento, Indústria e Comércio (2007) mostram que em 2006 as empresas dos Grandes Projetos - CVRD e coligadas, ArcelorMittal Tubarão, Samarco, Aracruz Celulose - tiveram uma participação de 75,4\% no valor das exportações estaduais ${ }^{244}$.

Este $3^{\circ}$ ciclo de desenvolvimento capixaba ${ }^{245}$, como é chamado este momento, aponta contundentemente para a continuidade da dependência das atividades industriais de base e da produção de commodities no setor industrial. Inclusive no setor de serviços, as atividades relacionadas ao comércio exterior, que estão em grande parte relacionadas a estes setores industriais, representam o ponto mais importante.

Paralelamente, o gráfico 6 apresenta o consumo de energia elétrica no Espírito Santo entre 2008 e 2017, com forte participação do setor industrial capixaba. Mesmo em 2017, um dos anos de menor consumo da série histórica apresentada, foram consumidos 7053,7 GWh pelo setor industrial, ou seja, 58\% da energia elétrica consumida no estado. Mas esta relação entre o parque industrial já instalado e o consumo de eletricidade no Espírito Santo será fortemente impactada pela crise energética de 2001.

\footnotetext{
${ }^{244}$ Ministério do Desenvolvimento, Indústria e Comercio, 2007.

${ }^{245}$ Espírito Santo (ESTADO). Planejamento de Desenvolvimento ES, 2006. p. 15. Disponível em: https://planejamento.es.gov.br/Media/sep/Plano\%20ES\%202025/Plano\%20de\%20Desenvolviment o\%20ES\%202025.pdf Acessado em: 08 dez. 2020.
} 


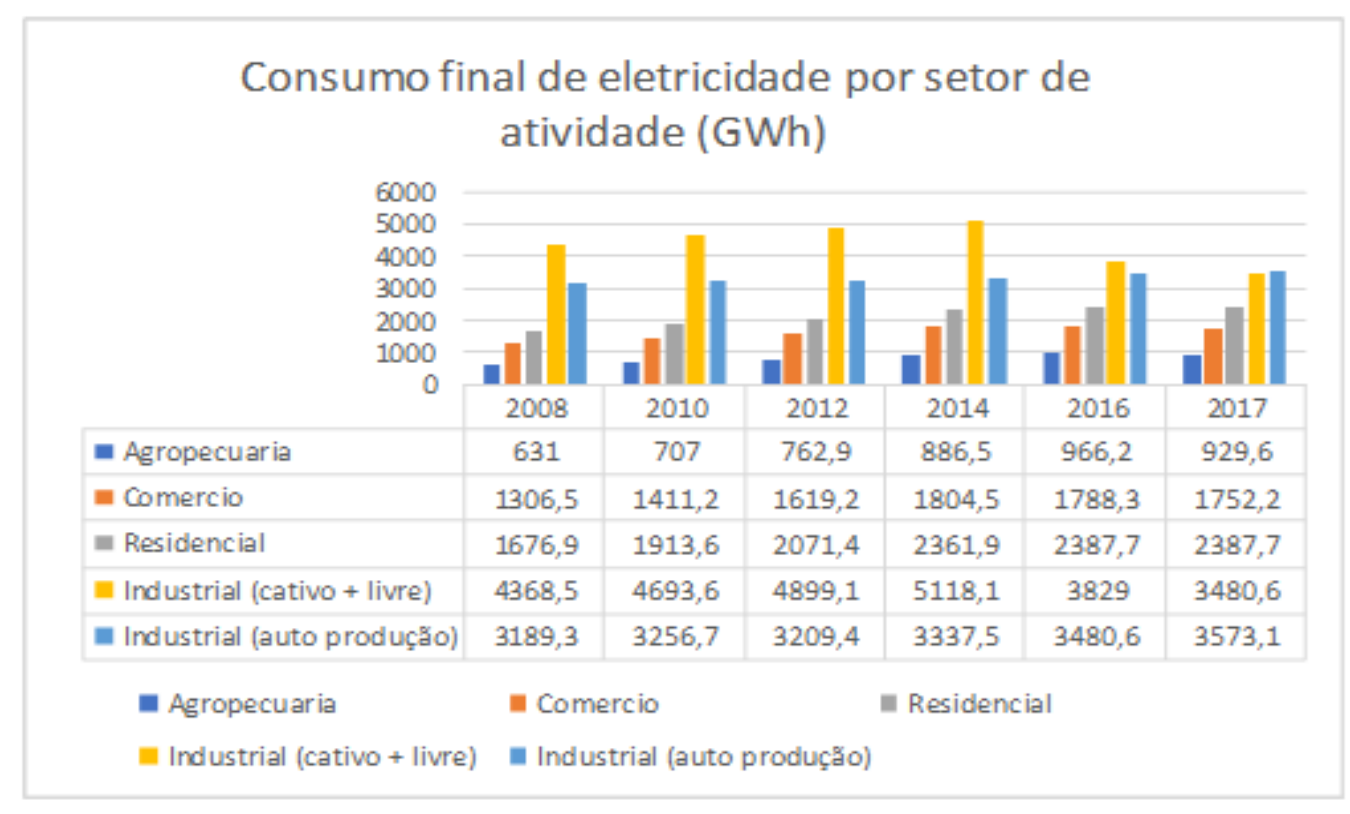

Gráfico 5 - Fonte: Agência reguladora de serviços públicos do Espírito Santo (ARSP)

\subsection{Do papel da crise elétrica de 2001 ao desenvolvimento do Mercado de}

\section{Energia Elétrica}

No cenário nacional, embora houvesse a percepção nas diversas empresas do setor, no Ministério de Minas e Energia (MME), na Agência Nacional de Energia Elétrica (Aneel) e Operador Nacional do Sistema (ONS), de que uma crise de falta de energia elétrica no sistema nacional tinha grande probabilidade de ocorrer ainda em $1997^{246}$, o governo Fernando Henrique Cardoso (PSDB) não conseguiu implantar um ambiente regulatório adequado e nem um mercado livre confiável no Mercado Atacadista de Energia (MAE). A Comissão Mista do Congresso Nacional, criada para tratar do tema em 2002, corrobora esta condição ao afirmar que:

\footnotetext{
"A reestruturação foi iniciada pela privatização das empresas do setor, sem que se dispusesse de uma clara regulamentação do mercado, indispensável, notadamente, para investimentos em geração e transmissão"247
}

Um outro aspecto é que, os grupos internacionais compradores das estatais regionais do setor elétrico, financiaram suas compras tomando empréstimos de curto prazo de bancos nacionais - BNDES - e internacionais. Dessa forma, assim

\footnotetext{
${ }^{246}$ GOLDENBERG E PRADO, 2003.

247 BRASIL. Congresso. Comissão Especial Mista destinada a estudar as causas da crise de abastecimento de energia no País, bem como, propor alternativas ao seu equacionamento. Relatório Final $\mathrm{n}^{\circ}$ 2, Relator Paulo Souto (PFL). Brasília, DF: Câmara dos Deputados, Coordenação de Publicações, 2002, p. 34
} 
que esses recursos chegavam ao país, tinham de atender à remessa de lucros da empresa privatizada, ao pagamento de juros e amortizações do dinheiro que foi financiado, não havendo espaço para os investimentos necessários ${ }^{248}$.

Além disso, a resistência política enfrentada pelo governo à reforma do setor elétrico, aliada a crise cambial brasileira, levou a um processo de desestatização incompleto, com a não privatização das grandes geradoras da Eletrobrás e à incapacidade da rolagem da dívida das empresas devedoras, que piorava mais a situação das contas nacionais. Assim, a necessidade de solução dos problemas na infraestrutura elétrica do país, já adiada por tanto tempo,

"não permitiu que se adotasse a sequência lógica de ter primeiro um
plano para depois executá-lo. A expansão da oferta era inferior à
demanda já desde 1990. [...] As contingências e prazos do processo
político, impunham que etapas fossem queimadas e, principalmente,
que se criasse uma pressão reformista por meio do início das
privatizações. Seguiu-se apenas a diretriz de privatizar."

Esta situação é agravada por uma política de austeridade fiscal do governo federal da gestão Fernando Henrique Cardoso (PSDB), que impediu as geradoras federais de fazerem novos investimentos, já que estes eram contabilizados como gastos do setor público e comprometiam as metas pretendidas de superávits primários.

É possível ver no gráfico 7 que o comportamento dos investimentos no setor elétricos, já entre 1987 e 1997, apontava para a redução em quase 3 vezes no decorrer dos 10 anos, sem a devida correção nos anos posteriores.

${ }^{248}$ GOLDENBERG E PRADO, 2003.

249 BRASIL. Congresso. Comissão Especial Mista destinada a estudar as causas da crise de abastecimento de energia no País, bem como, propor alternativas ao seu equacionamento. Relatório Final $n^{\circ}$ 2, Relator Paulo Souto (PFL). Brasília, DF: Câmara dos Deputados, Coordenação de Publicações, 2002, p. 34 e 35 . Disponível em: http://legis.senado.leg.br/sdleggetter/documento?dm=3951259\&disposition=inline Acessado em 03 de agosto de 2020. 


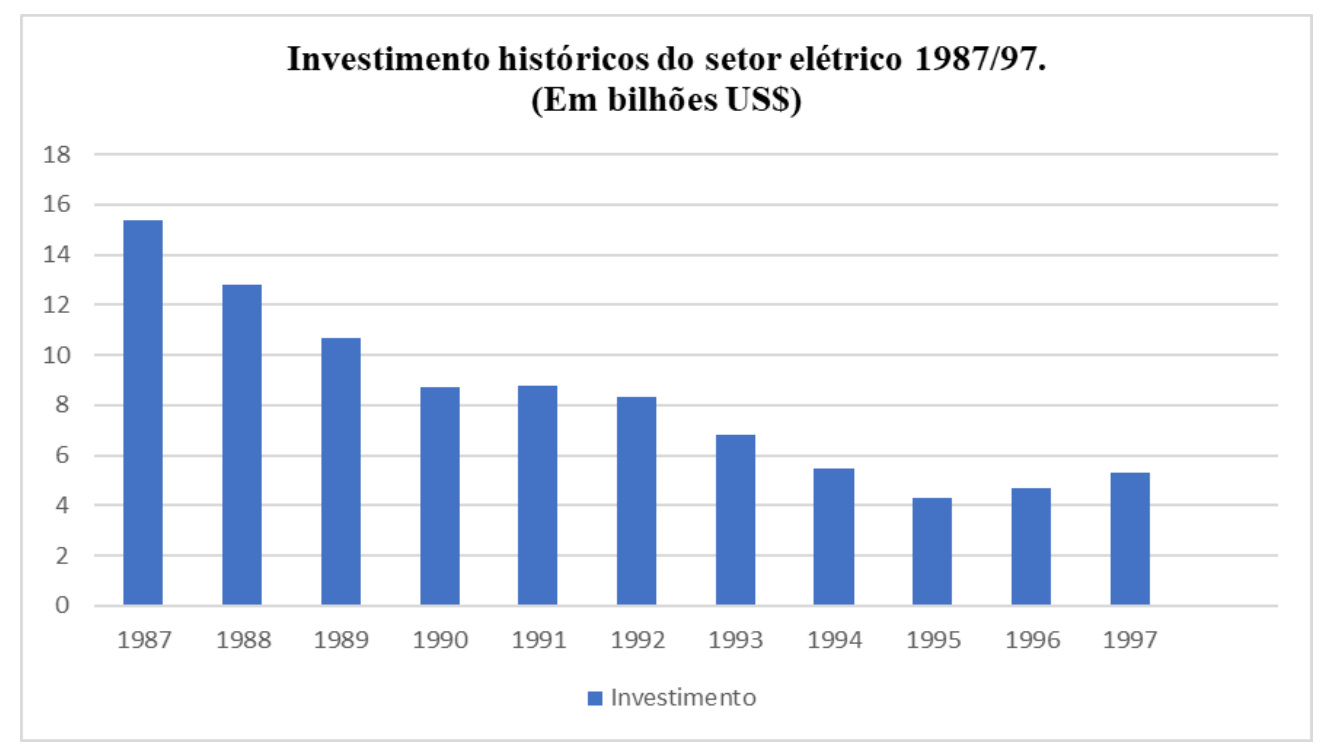

Gráfico 6 - Fonte: Eletrobrás, 1998 e Ferreira (2000), adaptado.

A situação piora ainda mais quando em abril de 2001 o armazenamento dos reservatórios das maiores hidroelétrica do país chega a pouco mais de $30 \%$ de sua capacidade, indicando a possibilidade de secarem quase completamente antes da nova estação de $\operatorname{chuvas~}^{250}$. Foi implementado, então, entre $1^{\circ}$ de junho de 2001 a $1^{\circ}$ de março de 2002, o racionamento de energia em escala nacional.

É importante apontar para a criação, ainda em 1999, por parte do Ministério das Minas e Energia do Programa Prioritário de Termoeletricidade (PPT), visando minimizar o risco de déficit entre produção e consumo de energia, que já representava um risco de abastecimento, da construção e entrada em operação de 49 termoelétricas a gás e óleo combustível num período máximo de dois anos, ou seja, até 2002. A crise, sem dúvidas, foi um dos motivos de consolidação do PPT, mas ele também era uma tentativa direta de ajuste das reformas no setor, introduzindo, entre outras coisas, a garantia de oferta de geração para fazer frente ao risco da crise, em detrimento do mercado $s p o t^{251}$, que ainda não havia funcionado.

Com o término do racionamento, em dezembro de 2001, a União instituiu um conjunto de medidas com objetivo de gerenciar a crise e promover sua superação, incluindo uma recomposição tarifária - devido ao período do

${ }^{250}$ GOLDENBERG e PRADO, 2003.

${ }^{251}$ Ambiente onde os geradores e comercializadores de energia elétrica realizarão contratos livremente acordados entre si e liquidam os montantes de energia não contratados comercializados no curto prazo, ou "mercado spot" (BETTEGA e RAMOS, 2001, p. 43). 
racionamento - com adiantamentos de recursos do BNDES, além da compra de energia elétrica emergencial pela empresa estatal criada para esse fim, a CBEE (Comercializadora Brasileira de Energia Emergencial) $^{252}$.

Mesmo com a escalada da privatização do setor, e um mercado meio aberto e meio regulado neste momento, é possível dizer que o governo federal, com relação à atuação da iniciativa privada e a intenção de descentralização do sistema elétrico nacional, continuou responsável pelo abastecimento de energia nacional. Em relação a isto, é importante destacar as conclusões da Comissão Especial Mista do Congresso Nacional, em 2001, a respeito do papel do Estado no setor de energia elétrica, mesmo após o processo de desestatização dos anos 1990:

"Fundamental nisso tudo foi o reconhecimento, pelo Ministro Pedro
Parente, de que, não importa quem preste os serviços de energia
elétrica, a responsabilidade pelo abastecimento nacional é da União, o
que se coaduna com o que está expresso no art. 21 da Constituição
Federal, que estabelece que a ela compete a exploração direta ou
mediante autorização, concessão ou permissão dos serviços e
instalações de energia elétrica e o aproveitamento energético dos cursos
d" água."253 Aproveitando os reflexos desta situação, o então candidato à presidência da república, Luís Inácio Lula da Silva (PT), enfatiza a necessidade de revisar a política estatal para o setor elétrico. E logo ao assumir a presidência, em 2003, inicia o esboço de um projeto de lei ${ }^{254}$ que tinha o objetivo de rever o modelo de gestão do setor. Em dezembro do mesmo ano, o projeto é finalizado no Ministério das Minas e Energia (MME), sendo visto como um novo "Modelo Institucional do Setor Elétrico".

Assim, o modelo implantado no Brasil a partir de 2004 teve como objetivos centrais, tanto criar condições para a realização de investimentos - públicos e privados - em geração, tendo em vista a necessidade de se evitar uma nova crise de abastecimento, quanto adequar a abertura do mercado de eletricidade às diretrizes da nova gestão federal ${ }^{255}$.

${ }^{252}$ Que é extinta em 2007, pelo decreto $\mathrm{n}^{\circ} 6.191$ de 20/08/2007.

253 BRASIL. Congresso. Comissão Especial Mista destinada a estudar as causas da crise de abastecimento de energia no país, bem como propor alternativas ao seu equacionamento. Relatório Final $\mathrm{n}^{\circ}$ 2, Relator Paulo Souto (PFL). Brasília, DF: Câmara dos Deputados, Coordenação de Publicações, 2002, p.164. Disponível em: http://legis.senado.leg.br/sdleggetter/documento?dm=3951259\&disposition=inline Acessado em 04 de agosto de 2020.

${ }^{254}$ Projeto de Lei $\mathrm{n}^{\circ} 3.337 / 04$.

${ }^{255}$ Neste sentido, uma das mudanças mais profundas e talvez a mais duradoura deste novo modelo, foi a constituição de dois ambientes de negociação para a comercialização de energia elétrica a 
Constitui-se aí dois mercados, o regulado e o livre, dando-se mais importância para o mercado regulado, já que as distribuidoras passaram a determinar a estimativa de demanda de eletricidade para 3 e 5 anos. Com base no somatório destas estimativas, foram realizados leilões, dando aos vencedores contratos que variavam de 15 a 30 anos, dependendo da fonte da planta de geração.

Este modelo conseguiu firmar um padrão de financiamento de longo prazo, além de determinar a segurança jurídica e marco regulatório protegido. Isso pode ser constado a partir de duas questões. A primeira, em que os leilões de geração apresentaram mais oferta do que demanda, e a segunda, que apresentou o contexto de fusões e aquisições, com destaque para a forte participação do grupo estatal chinês State Grid. ${ }^{256}$

Contudo, o modelo comercial do Setor Elétrico Brasileiro começa novamente a se apresentar financeiramente instável, justamente em períodos de

partir do decreto federal $n^{\circ}$ 5.163/2004: (1) o Ambiente de Contratação Regulada (ACR), com agentes de geração e de distribuição de energia que podem apenas negociar energia somente nos leilões de energia existente promovidos pela Câmara de Comercialização de Energia Elétrica (CCEE), sob delegação da Aneel e, (2) o Ambiente de Contratação Livre (ACL), com livre negociação de valores e contratos entre geradores, distribuidores, comercializadores, importadores e exportadores, além dos consumidores livres e especiais, em livre negociação entre os compradores e vendedores. Este modelo foi derivado do MAE - Mercado Atacadista de Energia, instituído em 27 de maio de 1998. O MAE se tratava de um ambiente virtual, sem personalidade jurídica, com função de intermediar em todas as transações de compra e venda de energia elétrica, assim como a contabilização e formação de preços que reflita o custo marginal do sistema. A estrutura do MAE apresentava conflitos de interesses, entre vendedores e compradores, resultando em paralisia do mercado e falta de credibilidade, consequentemente, deixando de cumprir suas atribuições - crítica recorrente durante a crise de abastecimento de 2001. Em linhas gerais, o objetivo destas reformas era criar um modelo que permitisse a sociedade benefícios de longo prazo de mecanismos de mercado, notadamente estimulando onde fosse possível, a concorrência entre agentes econômicos. A característica mais marcante deste novo modelo foi a contratação compulsória, pelos consumidores, de garantia física em volume equivalente a $100 \%$ do consumo. Neste sentido, não se negociaria mais a energia como produto, mas sim um contrato financeiro baseado na necessidade de consumo. A garantia física de cada usina, tendo em vista sua capacidade de produção, seria calculada pelo Ministério de Minas e Energia, utilizando uma metodologia definida por ela em sua função reguladora. Além disso, os contratos de garantia física são assignados no mercado regulado mediante os leilões de energia nova. Estes leilões podem ser realizados em diversos formatos, tendo como principais os leilões A-5, cinco anos antes do início do suprimento e A-3, três anos antes do início de suprimento. Complementarmente, o modelo conta com um mecanismo de conciliação das diferenças entre os montantes contratados e os montantes medidos, isto é, a energia efetivamente produzida e consumida, chamado de Mercado de Curto Prazo. As diferenças são valoradas a um preço específico, denominado Preço de Liquidação das Diferenças, calculado em modelos computacionais.

256 Ver mais em: COHEN, Sandra. Como a State Grid se tornou a líder do setor elétrico brasileiro. Revista Negócio, Rio de Janeiro, 12 julho de 2019. Disponível em: https://epocanegocios.globo.com/Empresa/noticia/2019/07/como-state-grid-se-tornou-lider-dosetor-eletrico-brasileiro.html. 
crise hidrológica prolongada, como a que vai se apresentar em 2014, tendo em vista, a predominância da geração por hidroelétricas no país a várias décadas ${ }^{257}$.

Este cenário provocou um grande impacto financeiro para os agentes envolvidos no setor elétrico nacional: consumidores, geradores a partir de fontes hídricas que tiveram incapacidade ou déficit de geração, geradores térmicos que por qualquer razão não conseguiram gerar a energia requerida pelo Operador Nacional do Sistema (ONS) e geradores que tiveram a entrada em operação em atraso.

A partir desta nova crise, entre outubro de 2012 e o início de 2016, o ONS aciona a maior parte das usinas termoelétricas existentes ${ }^{258}$, que operaram continuamente até 2020, a fim de evitar um novo racionamento. Além disso, a União reagida à crise financeira no setor elétrico com uma série de inovações regulatórias, destinadas essencialmente a manter o sistema solvente. As distribuidoras foram socorridas - novamente -, primeiro mediante aportes do Tesouro Nacional, e depois com a captação de empréstimos via CCEE, garantidos por aumentos futuros da tarifa dos consumidores cativos ${ }^{259}$.

Mesmo assim, uma grande quantidade de ações judiciais se avoluma desde 2015, resultando na paralização do mercado e obrigando o Governo Federal a oferecer uma repactuação do risco hidrológico ${ }^{260}$. Neste ínterim, cabe apontar as análises de Castro et al. (2017) sob este modelo atual do mercado de energia:

\begin{abstract}
"O fato de o modelo comercial brasileiro ser baseado em contratos de longo prazo é adequado do ponto de vista da expansão da capacidade, embora ele tenha se mostrado arriscado e financeiramente frágil durante a recente crise hidrológica. $\mathrm{O}$ problema parece, pelo menos em parte, ter um caráter estrutural, isto é, estar associado ao desenho do modelo de comercialização de energia no atacado brasileiro. [...] Grosso modo, pode-se afirmar que os mercados de energia funcionam melhor em países onde a energia é gerada principalmente a partir de fontes térmicas, em função da previsibilidade da geração e de seus custos.
\end{abstract}

\footnotetext{
${ }^{257}$ Em 2018, 64\% da geração de eletricidade no Brasil foi proveniente de hidroelétricas. (EPE, 2019) 258 Muitas delas de operação sazonal.

259 Consumidor ao qual só é permitido comprar energia da distribuidora detentora da concessão ou permissão na área onde se localizam, em sua maior parte, consumidores residenciais.

${ }^{260}$ Corresponde à relação entre o volume de energia que é gerado pelas usinas e a garantia física total delas. Dentro das leis atuais que regem o setor elétrico, caso uma usina hidrelétrica gere energia abaixo da sua garantia física, ela é penalizada e deve pagar por essa diferença. Um dos motivos que faz com que as usinas forneçam energia abaixo da sua garantia física é a falta de chuvas e queda no volume das hidrelétricas. Como o Brasil é um país extenso e as condições climáticas são adversas, foi criado o Mecanismo de Realocação de Energia (MRE), em que há a possibilidade de transferência de energia de uma usina para outra. Ou seja, uma hidrelétrica que gerou acima da sua garantia física pode transferir energia para outra que gerou abaixo. Assim, soma-se toda a garantia física das usinas que compõem o MRE e toda a energia que foi gerada. Caso o volume elétrico realmente gerado seja menor do que a garantia física, as hidrelétricas têm que pagar a diferença. Esse é o risco hidrológico, estipulado a partir das previsões para as condições de geração, como volume de chuvas, paradas para manutenção.
} 
Nestes mercados, o preço da usina marginal tende a ser igual ao custo variável de geração associado ao preço do combustível que ela utiliza. No caso dos mercados onde a geração depende, em grande medida, de fontes renováveis, essa correlação se enfraquece e os preços podem ser muito baixos por longos períodos (CASTRO et al., 2014)."

\subsection{A necessidade de geração de energia no Espírito Santo e o avanço das termoelétricas}

Toda esta crise de abastecimento de energia elétrica com os apagões, racionamento e crise regulatória, atingiu em cheio o território capixaba. O que faz a Federação das indústrias do Estado do Espírito Santo (FINDES) cobrar sistematicamente, ainda durante crise de abastecimento de 2001, a melhoria do sistema elétrico com o aumento da produção interna ${ }^{261}$.

Relevante neste ponto destacar a histórica dependência capixaba da eletricidade do Sistema Nacional Integrado (SNI), presente no gráfico 7, e perceber sua ligação com os anos de maior de consumo industrial presentes no gráfico $6 .{ }^{262}$

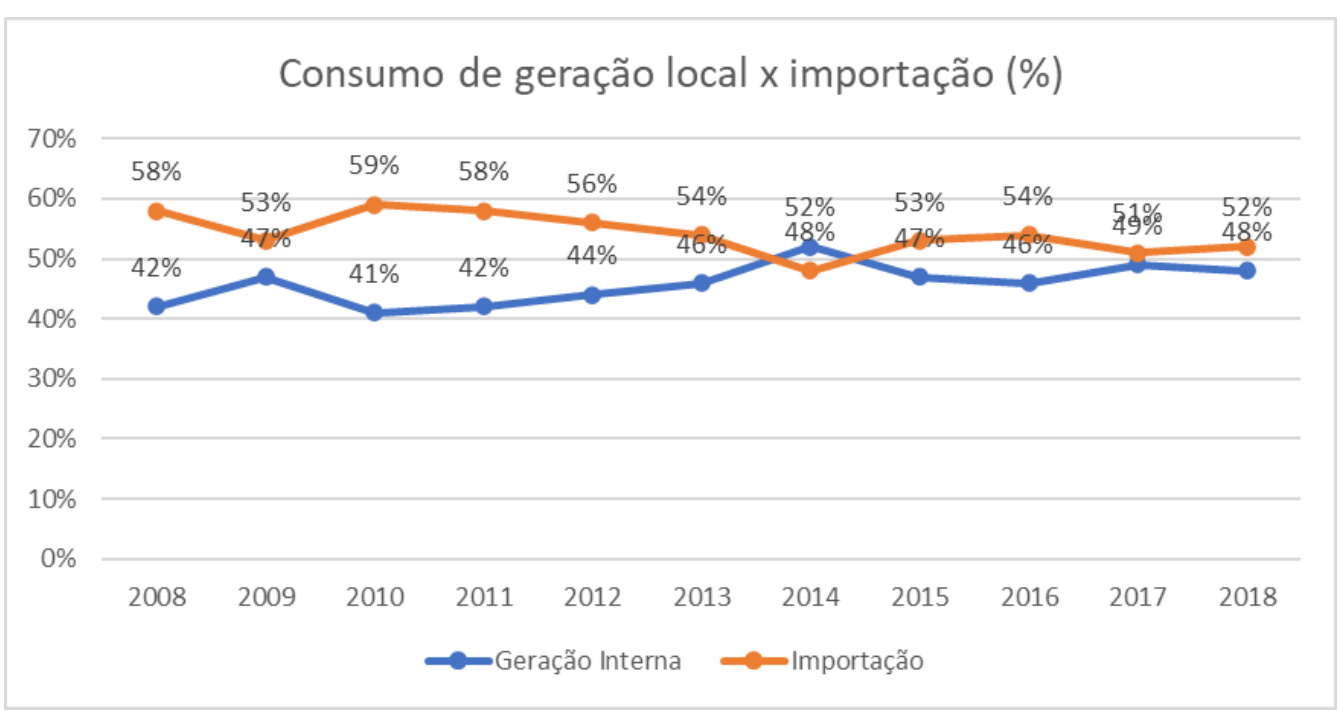

Gráfico 7 - Fonte: Agência Reguladora dos Serviços Públicos do Espírito Santo (ARSP)

Tendo em vista o cenário, em 2001 a ESCELSA, já privatizada, recebe um aporte de R\$ 196 milhões do BNDES ${ }^{263}$ para recomposição das perdas com o racionamento, investimento em geração, além da incorporação dos projetos dos

\footnotetext{
${ }^{261}$ FINDES cobra geração de energia no Estado. Jornal A Gazeta. 23 de janeiro de 2002, p. 7. 262 p. 169

${ }^{263}$ Escelsa recebe R\$ 196 milhões do BNDE. Jornal A Gazeta. 12 de março de 2002, p. 4.
} 
linhões de transmissão para melhoria da ligação entre a rede capixaba e o serviço de Furnas e da CEMIG.

Em 2003 o governo do Espírito Santo dá incentivos a geração térmica ${ }^{264}$, inclusive aquela relacionada à produção a partir de empreendimentos industriais autoprodução. Em 2007, leva à realização de um leilão de energia nova ${ }^{265}$, com previsão de instalação de 7 plantas de geração para atendimento a toda rede ${ }^{266}$.

Isto demonstra que o caminho adotado pelo estado para superar a crise de abastecimento, assim como no contexto nacional, passaria pela expansão a partir de termelétricas. Algo que não seria necessariamente novo no estado. Por mais que esta situação estivesse umbilicalmente relacionada à solução nacional, o quadro das crises de abastecimento - que passavam pela solução térmica como um remédio rápido e financeiramente viável -, no contexto capixaba, aliou-se a um histórico já consolidado de autoprodução de energia de uma indústria eletrointensiva.

Como é possível ver na tabela 5 e 6, as termelétricas instaladas no Espírito Santo são em sua maioria fruto de autoprodução, particularmente a partir de empresas extrativistas, de aço e papel e celulose - justamente aqueles setores presentes no passado (e atualmente) - e de projeto de desenvolvimento capixaba entre as décadas de 1960, 1970, 1980 e 1990. É assim que entre 2008 e 2018 as termelétricas provenientes de fontes não renováveis representaram mais de $50 \%$ da eletricidade produzida no estado ${ }^{267}$, chegando a impressionantes 66,60\% em 2016.

\begin{tabular}{|l|r|}
\hline \multicolumn{2}{|c|}{ Tabela 4 - Termelétricas no Espírito Santo } \\
\hline Usina & Potência (MW) \\
\hline CST $^{*}$ & 225,10 \\
\hline Aracruz* & 210,40 \\
\hline UTE Luiz Oscar Rodrigues de Melo ${ }^{* *}$ & 204,00 \\
\hline Viana & 174,30 \\
\hline Sol* & 147,30 \\
\hline
\end{tabular}

\footnotetext{
${ }^{264}$ Investimentos garantem térmicas em 2003. Jornal A Gazeta, Vitória, ES, 20 de setembro de 2001, p.07.

${ }^{265}$ Nesses leilões, os empreendedores concorrem para a instalação e operação de usinas de geração para atender o crescimento da demanda prevista. Com o objetivo preencher o aumento de carga das distribuidoras.

${ }^{266}$ Contudo, até 2020, apenas duas haviam sido construídas.

${ }^{267}$ Ministério das Minas e Energia (MME), 2018.
} 


\begin{tabular}{|c|c|}
\hline Alcon* & 11,20 \\
\hline Biancogrés* & 5,11 \\
\hline João Neiva & 3,50 \\
\hline Subestação CPD* & 3,22 \\
\hline Paineiras* & 3,20 \\
\hline Lasa* & 3,20 \\
\hline Vale Complexo de Tubarão GE2* & 2,56 \\
\hline Vale Complexo de Tubarão GE1* & 2,56 \\
\hline Apart Hospital* & 2,10 \\
\hline Shopping Praia da Costa* & 1,80 \\
\hline Leão Linhares* & 1,60 \\
\hline Vale Complexo de Tubarão 7GE* & 1,60 \\
\hline Vale Complexo de Tubarão GE8* & 1,60 \\
\hline Fibrasa Embalagem* & 1,10 \\
\hline Atacadão SA Vila Velha* & 0,80 \\
\hline Shopping Vila Velha* & 0,76 \\
\hline Atacadão SA Serra* & 0,72 \\
\hline VTA JM* & 0,70 \\
\hline Wallmart Sams Vitória* & 0,64 \\
\hline ETE Coronel Borges & 0,61 \\
\hline Fibrasa Sudeste* & 0,55 \\
\hline $\begin{array}{l}\text { Editora e Distribuidora Pitágoras } \\
\text { Linhares* }\end{array}$ & 0,36 \\
\hline Autosserviço FAÉ* & 0,35 \\
\hline Laticínios Resende* & 0,35 \\
\hline Total & 1011,65 \\
\hline
\end{tabular}

*Autoprodutores. Fonte: SANTOS, 2015 e ARSP, 2015.

Tabela 5 - Geração de Energia Elétrica por Fonte (\%)

\begin{tabular}{|l|l|l|l|l|l|l|l|l|}
\hline \multirow{2}{*}{ GERAÇÃO POR FONTE } & \multicolumn{7}{|c|}{ ANO } \\
\cline { 2 - 9 } & $\mathbf{2 0 0 8}$ & $\mathbf{2 0 0 9}$ & $\mathbf{2 0 1 0}$ & $\mathbf{2 0 1 2}$ & $\mathbf{2 0 1 4}$ & $\mathbf{2 0 1 6}$ & $\mathbf{2 0 1 7}$ & $\mathbf{2 0 1 8}$ \\
\hline RENOVÁVEL & $\mathbf{4 9 , 2}$ & $\mathbf{6 0 , 3}$ & $\mathbf{5 9 , 3}$ & $\mathbf{5 4 , 8}$ & $\mathbf{3 8 , 3}$ & $\mathbf{3 3 , 4}$ & $\mathbf{3 4 , 9}$ & $\mathbf{4 3 , 6}$ \\
\hline $\begin{array}{l}\text { Hidráulica (CGH, PCH e } \\
\text { UHE) }\end{array}$ & 24,1 & 35,0 & 33,8 & 31,3 & 20,0 & 13,2 & 14,4 & 24,7 \\
\hline
\end{tabular}




\begin{tabular}{|l|l|l|l|l|l|l|l|l|}
\hline $\begin{array}{l}\text { Térmica Renovável } \\
\text { (Biomassa de Cana, } \\
\text { Lixívia) }\end{array}$ & 25,1 & 25,3 & 25,5 & 23,5 & 18,3 & 20,2 & 20,5 & 18,9 \\
\hline NÃO-RENOVÁVEL & $\mathbf{5 0 , 8}$ & $\mathbf{3 9 , 7}$ & $\mathbf{4 0 , 7}$ & $\mathbf{4 5 , 2}$ & $\mathbf{6 1 , 7}$ & $\mathbf{6 6 , 6}$ & $\mathbf{6 5 , 1}$ & $\mathbf{5 6 , 4}$ \\
\hline $\begin{array}{l}\text { Térmicas Gases de Processo } \\
\text { (Aciaria, Coqueria, Alto } \\
\text { forno) }\end{array}$ & 50,8 & 39,7 & 40,7 & 32,6 & 28,9 & 40,5 & 36,4 & 35,1 \\
\hline Térmicas a Gás Natural & - & - & - & 8,1 & 18,9 & 21,4 & 20,8 & 18,5 \\
\hline Térmicas Óleo Combustível & - & - & - & 4,5 & 13,8 & 4,7 & 7,8 & 2,8 \\
\hline TOTAL & $\mathbf{1 0 0}$ & $\mathbf{1 0 0}$ & $\mathbf{1 0 0}$ & $\mathbf{1 0 0}$ & $\mathbf{1 0 0}$ & $\mathbf{1 0 0}$ & $\mathbf{1 0 0}$ & $\mathbf{1 0 0}$ \\
\hline
\end{tabular}

Tabela 6. Fonte: Agência Reguladora dos Serviços Públicos do Espírito Santo (ARSP), adaptado.

Outra questão que surge ao observarmos a tabela 6 é que, além da predominância da geração de energia por gases de processo, destaca-se uma franca expansão da utilização do gás natural como fonte para produção de energia pelas plantas termelétricas, a partir de 2012. O que também é demonstrado no gráfico 9 , na comparação da geração de energia por MWh:

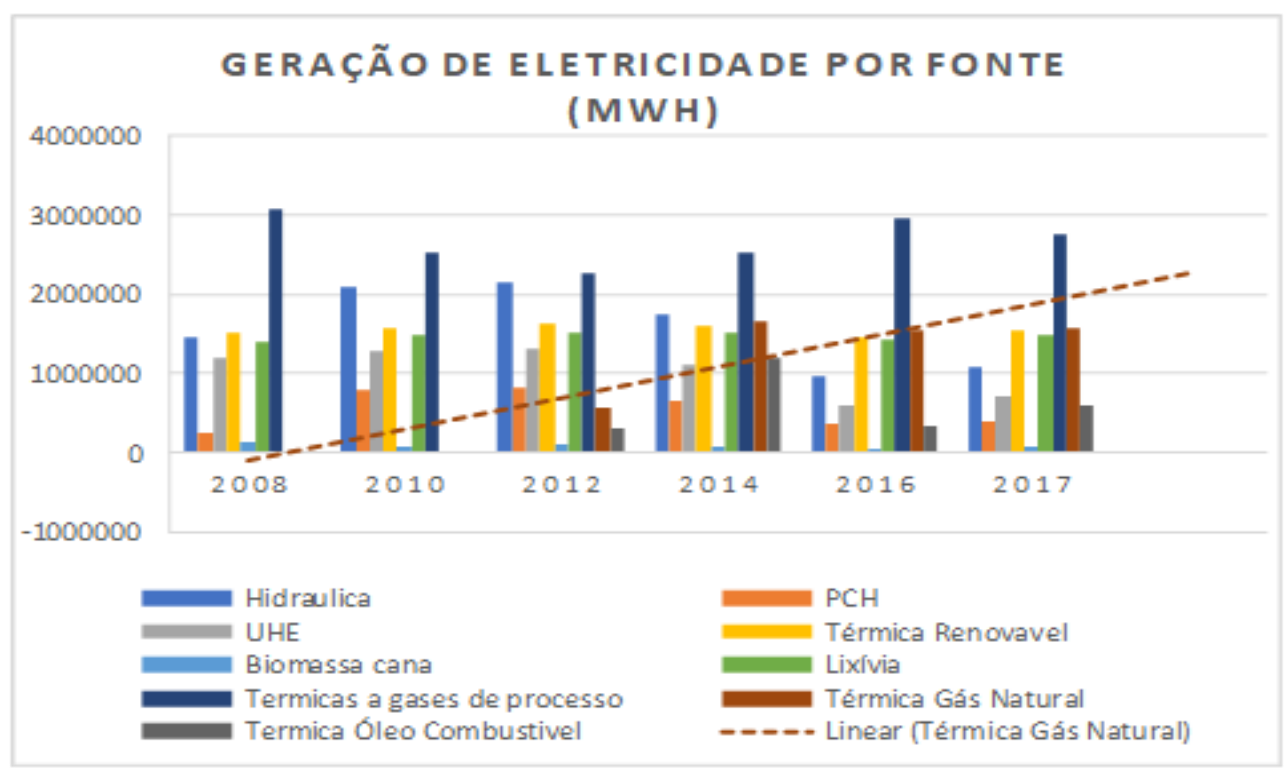

Gráfico 8 - Fonte: Agência Reguladora dos Serviços Públicos do Espírito Santo (ARSP)

Já mencionamos, mas é relevante destacar novamente que a implementação do gás natural no Espírito Santo, por estar diretamente associada à produção do 
setor industrial extrativista, apresenta expansão em território capixaba com o incremento da produção na Bacia de Campos ${ }^{268}$, nos anos 1990.

Mesmo ganhando corpo apenas no final do século passado, a atividade de prospecção, extração e processamento de petróleo e gás natural, foi iniciada no estado ainda em 1957, com a descoberta de seu primeiro campo viável para produção comercial em 1969. O desenvolvimento do setor de petróleo em território espírito-santense pode ser pensado levando em conta dois períodos históricos diferentes. No primeiro, que dura até 1994, o setor era controlado pela União, sob tutela da Petrobras, que deteve o monopólio de exploração, produção, refino e transporte marítimo no Brasil e no Espírito Santo.

O segundo período se inicia a partir da aprovação, em 1995, da Emenda Constitucional $\mathrm{n}^{\circ} 5$, que alterou a Constituição Federal brasileira e flexibilizou o monopólio da Petrobras, possibilitando a atuação de empresas privadas em todos os elos da indústria do petróleo. Isto permitiu, além da desregulamentação dos preços, a participação de empresas privadas no setor e a criação da Agência Nacional do Petróleo, Gás Natural e Biocombustíveis (ANP).

Não há dúvida de que o modelo regulatório produzido em 1998 possibilitou a atração de novos investimentos, uma maior participação dos entes federados sobre as receitas geradas pelas atividades do setor e o fortalecimento da Petrobras. Neste contexto, a produção brasileira total de petróleo líquido e de gás natural (LGN) mais do que dobrou, saltando de 1,24 milhão de barris equivalentes de petróleo por dia (bep/d) em 1998, para 2,5 milhões de bep/d em 2009.

Mesmo que a produção de gás tenha sido reduzida em 2009 em função da crise mundial do ano anterior, o Espírito Santo representou, naquele ano, 5,1\% da produção nacional de petróleo e gás. As reservas provadas de gás no estado corresponderam a $13 \%$ das brasileiras em $2009^{269}$.

Nos gráficos 10 e 11 é possível perceber a contínua escalada da produção de gás natural desde 2005, na qual o setor de energia se coloca como principal consumidor de gás natural, com um crescimento contínuo desde 2008.

\footnotetext{
${ }^{268}$ A Bacia de Campos é uma bacia sedimentar brasileira situada na costa norte do estado do Rio de Janeiro, estendendo-se até o sul do estado do Espírito Santo. A bacia compreende $100 \mathrm{mil}$ quilômetros quadrados, sendo a maior província petrolífera do Brasil, responsável por mais de $80 \%$ da produção nacional do petróleo.

${ }^{269}$ Instituto Jones dos Santos Neves (IJSN). Espírito Santo: instituições, desenvolvimento e inclusão social. Vitória, ES, 2010.
} 


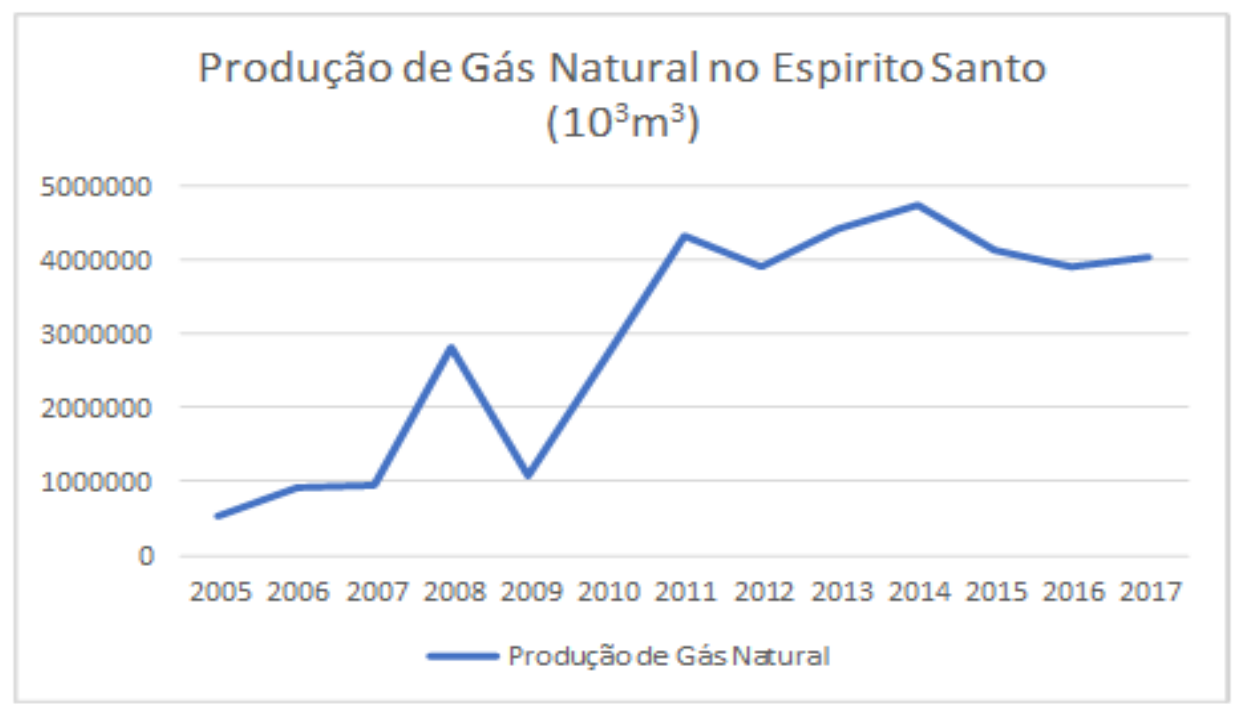

Gráfico 9 - Fonte: Agência reguladora de serviços públicos do Espírito Santo (ARSP), 2018.

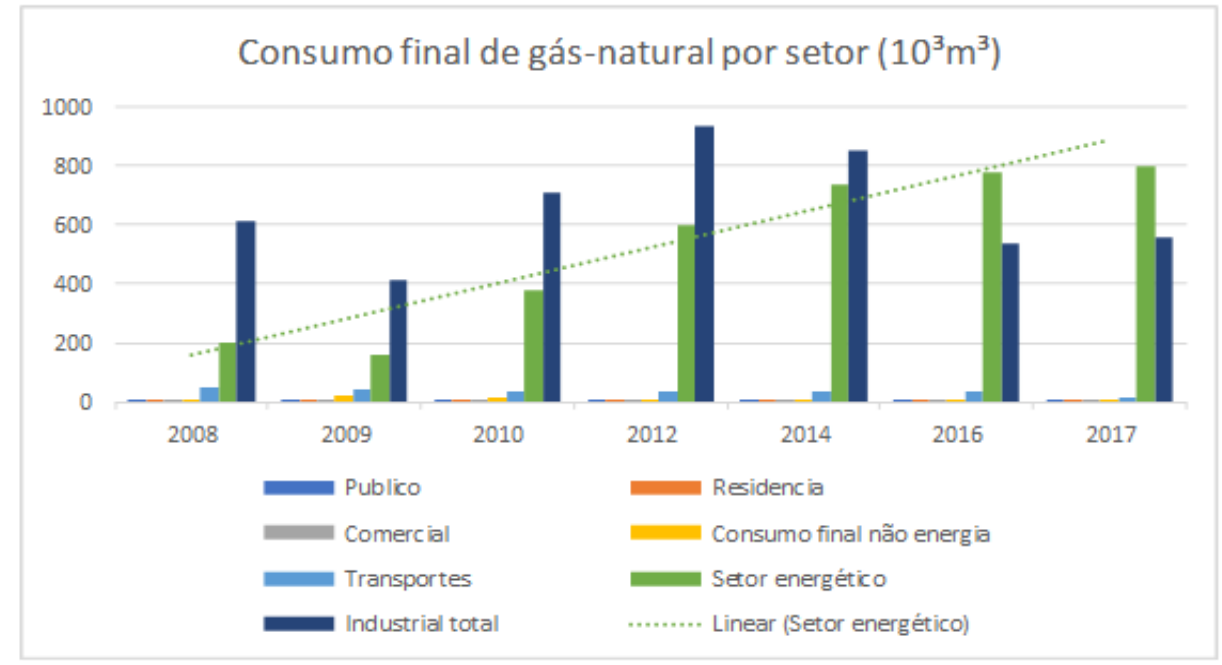

Gráfico 10 - Fonte: Agência reguladora de serviços públicos do Espírito Santo (ARSP)

Por fim, dentro deste panorama, destaca-se a utilização de gás natural para geração de energia em território capixaba como reflexo de um o cenário de exploração de petróleo, que se consolida a partir de uma política de leilões de energia nova ${ }^{270}$ - inserido na abertura do mercado nacional de energia - e sobretudo como resultado de um mercado de exploração e distribuição de gás ${ }^{271}$. Fatos que

${ }^{270}$ Estado ganha mais 7 usinas. A Tribuna, Vitória, ES, 01/10/2008, p.27, c.1-2. e Hartung pede a Lula novo linhão e termelétrica contra o apagão. A Gazeta, Vitória, ES, 02/10/2007, p.16, c.1-4.

${ }^{271}$ Contextualizando: a Petrobras deteve o monopólio sobre as atividades das indústrias de petróleo, seus derivados e gás natural no Brasil até 1995, quando foi aprovada a Emenda Constitucional $\mathrm{n}^{\circ} 9$ que flexibilizou esse monopólio da União. Na Lei do Petróleo (Lei nº 9.478/1997), foi 
são cruciais na manutenção do protagonismo da produção de energia no Espírito

Santo, por fontes térmicas e não renováveis.

regulamentada, mas não promoveu significativa alteração da estrutura do mercado, permanecendo a Petrobras como agente dominante, quando não monopolista de fato. Em 2009, a Lei do Gás (Lei $\mathrm{n}^{\circ} 11.909 / 2009$ ) foi publicada, para tratar as especificidades da indústria do gás natural. Em 2015, a Petrobras inicia o processo de desinvestimentos de alguns ativos do setor de gás natural e reduz sua participação no mercado, o que representa a revisão do marco legal e regulatório setorial. Diante disso, é em junho de 2016 que se lança a iniciativa Gás para Crescer, que contou com a participação de agentes da indústria do gás natural, órgãos governamentais, sociedade civil e universidades nas discussões. Nesse âmbito, foi publicada a Resolução CNPE n ${ }^{\circ}$ 10/2016, estabelecendo as diretrizes estratégicas para o desenho de um novo mercado de gás natural, visando à formação de um mercado líquido. Essa Resolução criou também o Comitê Técnico para o Desenvolvimento da Indústria do Gás Natural no Brasil (CT-GN), com o objetivo de propor medidas que garantissem a transição gradual e segura para a manutenção do adequado funcionamento do setor de gás natural e de avaliar a possibilidade de aceleração da transição. Em 2019 é instituído o Comitê de Promoção da Concorrência do Mercado de Gás Natural no Brasil, por meio da Resolução CNPE nº 4/2019, com competências para propor medidas de estímulo à concorrência no mercado de gás natural, encaminhar ao CNPE recomendações de diretrizes e aperfeiçoamentos de políticas energéticas voltadas à promoção da livre concorrência no mercado de gás natural e propor ações a entes federativos para a promoção de boas práticas regulatórias. Resultado das propostas apresentadas por este Comitê, o CNPE aprovou a Resolução no 16/2019. Assim, em julho de 2019 é lançado o Programa do Novo Mercado de Gás, com proposta a criação do Comitê de Monitoramento da Abertura do Mercado de Gás Natural, que foi instituída por meio do Decreto nº 9.934/2019. 


\section{REFLEXÕES E CONCLUSÕES}

\section{A dependência da política e a necessidade da energia}

Este é o último momento desta pesquisa, que se propôs a explorar e refletir sobre a relação entre eletricidade e desenvolvimento estatal no Brasil, com foco nos desdobramentos políticos que influenciaram as configurações do setor de energia elétrica do estado do Espírito Santo. Tentou-se aqui, acima de tudo, realizar uma incursão histórica, respeitando os marcos importantes para o estabelecimento da eletricidade no país, a saber: (1) entre 1930 e 1946, levando em consideração o Estado varguista; (2) entre 1947 e 1964, entendendo a acentuação do Estado desenvolvimentista; (3) entre 1964 e 1980, olhando a consolidação da empresa pública; (4) e a partir da década de 1990 e o conjuntura de desestatização e abertura de mercado.

Um dos esforços empregados nesta tese foi o de compatibilizar o constructo teórico com a análise de dados documentais, a fim de melhor compreender os mecanismos e processos que ligaram os planos nacional ao regional ao longo do tempo. Esta perspectiva considera os referenciais utilizados, tanto aqueles relativos ao controle político sobre a energia e através dela, quanto os relativos às características de desigualdades do federalismo nacional, as políticas desenvolvimentistas estatais e a disputa pelo poder político estatal.

Neste sentido, a pesquisa buscou cumprir com a premissa de chamar atenção para necessidade do estudo destas dinâmicas políticas que orbitaram a implementação dos projetos de infraestrutura elétrica, especialmente sobre o seu impacto nos setores elétricos regionais.

A respeito destas questões, podemos dizer, primeiramente, que o desenvolvimento do setor elétrico brasileiro nas primeiras décadas do século $\mathrm{XX}$ começa antes pelas regiões e depois pelo contexto nacional, mais especificamente com início nos empreendimentos privados para o abastecimento de pequenas manufaturas e de serviços urbanos, como bondes e iluminação pública.

Os acontecimentos da década de 1930 não alteraram esta configuração de imediato, mas trouxeram a centralização política e a perspectiva de desenvolvimento nacional como novos elementos norteadores. Isto abriu caminho para o surgimento de regulamentações, como o código de águas em 1934, ajudando 
na constituição dos planos estaduais de aproveitamento de eletricidade que tiveram início na década de 1950.

Estes planos estabeleceram a prática da planificação no setor e disciplinaram o espaço de atuação do Estado e dos capitais privados, pela primeira vez, integrando os projetos de desenvolvimento econômico regionais. É importante dizer que a sinergia - ou simbiose - entre um projeto de desenvolvimento nacional e o setor elétrico no país relaciona-se à evolução destas capacidades estatais no território nacional e a sua intervenção na atividade econômica.

Sob este aspecto, esta pesquisa aponta a importância já reconhecida da Eletrobrás e do BNDE para a consolidação do setor elétrico nacional nas décadas de 1960 e 1970, indicando singularidades importantes a respeito do papel das empresas regionais na consolidação do setor. Vimos como COPEL, CEEE, e sobretudo a CEMIG foram importantes na estruturação política, técnica e administrativa do sistema nacional. No caso da CEMIG, especialmente, acompanhando um projeto desenvolvimento econômico implementado por Juscelino Kubitschek (PSD) como governador de Minas Gerais, e posteriormente, como presidente da república.

A esse respeito, algumas questões podem ser notadas. Primeiro, a relevância dos projetos das elites políticas sobre os projetos de desenvolvimento econômico regionais, cruciais para a consolidação da infraestrutura de energia elétrica. Por outro lado, se mostra igualmente relevante a influência do ambiente federativo na configuração das estratégias destas elites políticas para execução dos seus projetos.

Neste ínterim, é importante chamar atenção também para a relevância do Partido Social Democrático (PSD). Este partido aglutinou tanto nacionalmente, quanto regionalmente, boa parte dos grupos políticos que estiveram envolvidos nos projetos desenvolvimentistas, que também estiveram envolvidos nos projetos elétricos. Isso fica claro nos casos do Paraná, de Minas Gerais, bem como no Espírito Santo, onde este partido aglutinou boa parte dos políticos capixabas até 1964 e, mesmo após o golpe de estado, formando um dos maiores blocos dentro da ARENA e participando ativamente da Federação das Indústrias do Estado do Espírito Santo (FINDES).

Uma segunda questão que se coloca com relação às infraestruturas elétricas regionais é a utilização das empresas para domínio da máquina pública modernizada. O que fica bem claro no caso capixaba, levando ao que chamamos de 
um Estado-elétrico a partir da construção da Espírito Santo Centrais Elétricas (ESCELSA).

Esta questão parece ser mais ampla e parece se relacionar à sensibilidade das elites regionais às tendências de modernização estatal e, principalmente, aos processos de mudança no capitalismo nacional. Especialmente quando este quadro impactou nos projetos de poder e forçou a acomodação destes atores em busca da manutenção de seu capital político. Percebemos isso na influência da elite cafeeira sobre a agenda do desenvolvimento da eletricidade no Espírito Santo até a década de 1940, na importância da Federação das Indústrias do Espírito Santo (FINDES), no planejamento estatal e para os projetos elétricos a partir da década de 1960, bem como na relevância dos projetos políticos de Paulo Hartung (PMDB) e Renato Casagrande (PSB), mais recentemente como catalizadores de uma política federal de termoelétricas em território capixaba.

Podemos inferir que, nos estados da federação brasileira, o resultado do jogo doméstico de forças e sua relação com o contexto federativo, a priori, tem grande influência na trajetória de implementação dos setores elétricos e de sua configuração.

Essa tendência fica mais explícita quando observamos a dependência do Espírito Santo em relação à energia do Sistema Interligado Nacional (SIN). Dependência esta que foi balizada pelos interesses das elites políticas e econômicas locais, coaptadas pelo Estado nacional para seu projeto de desenvolvimento econômico, fundamentado na industrialização de base e na centralização da produção de energia, em favor dos centros de gravidade econômica do país.

Como reflexo, a necessidade de produção interna de energia elétrica no Espírito Santo, no momento posterior à crise de abastecimento de 2001, aliada à problemática regulamentação do setor elétrico e de seu mercado, após as reformas dos anos 1990 e 2000, acentuou projetos de usinas termoelétricas - a gases de processo, a gás natural, carvão ou óleo combustível - que tem maior segurança regulatória, tempo de construção menor, eficiência maior e custos de construção e operação inferiores.

Neste cenário, que é atual - principalmente o que demarca a grande margem da produção por fontes não renováveis - coloca um paradoxo para o Espírito Santo: se por um lado o estado encontra-se cada vez mais inserido em uma lógica internacional, que pressupõe produção de energia descentralizada, por fontes 
renováveis e não poluentes, por outro lado tem um suprimento abundante e barato de gás natural e gases de processo, necessitando ser mais independente do suprimento do SNI.

Por fim, é relevante dizer que os resultados aqui apresentados apontam para a necessidade de se pensar uma política da eletricidade, que é cada vez mais relevante, tanto sob o ponto de vista das discussões sobre segurança energética, quanto em um contexto das energias renováveis. 


\section{REFERENCIAS:}

ACHIAMÉ, Fernando Antônio de Moraes. O Espírito Santo na era Vargas (1930- 1937): Elites políticas e reformismo autoritário. Rio de Janeiro: Editora FGV, 2010.

AGUIAR, Tais Florêncio de; HOLLANDA, Cristina Buarque de; CASTELO BRANCO, Pedro H. Villas Bôas. Cesar Guimarães: uma antologia de textos políticos. Appris Editora. Rio de Janeiro, 2019.

ALVES, Job de Figueiredo Silvério, RIBEIRO, Luiz Cláudio Moíses. A utilização do setor elétrico brasileiro na implementação políticas públicas (1930-1994). Revista Ágora, n.3, Vitória, 2006, p. 1-36.

AMSDEN, Alice H. (2001). The Rise of "The Rest": Challenges to the West from Late-Industrializing Countries. Oxford: Oxford University Press.

ANDRADE, Pablo de Oliveira. A legítima Representante: câmaras municipais, oligarquias e a institucionalização do império liberal brasileiro (Mariana, 1822-1836). Dissertação (Mestrado em História) - Instituto de Ciências Humanas e Sociais. Mariana: UFOP, 2012.

ANDREOLI, Arturo. jun. 1975. Energia elétrica no Brasil e no Paraná. Curitiba: COPEL.

ARRETCHE, Marta e RODDEN, Jonathan. Política distributiva na Federação: estratégias eleitorais, barganhas legislativas e coalizões de governo. Dados [online]. 2004, vol.47, n.3, pp.549-576. ISSN 1678-4588.

AUGUSTO, Maria Helena Oliva. Formulação do projeto de desenvolvimento paranaense. In: Intervencionismo estatal e ideologia desenvolvimentista. São Paulo: Símbolo, 1978.

APPADURAI, Arjun. Modernity at Large. Cultural Dimensions of Globalization. University of Minnesota Press. Minneapolis, 1996.

AQUINO, Artur. I Congresso Brasileiro de Economia 1943: atores, intelectuais e ideologias na constituição de uma consciência de classe entre os industriais e a consolidação do projeto industrialista. In PLURAL, Revista do Programa de Pós-Graduação em Sociologia da USP, São Paulo, v.17.1, 2010, pp.59-88.

ARARIPE, D. Alencar. História da Estrada de Ferro Vitória a Minas 19041954. Companhia Vale do Rio Doce. Rio de Janeiro, 1954.

AXL, Gunter. A participação da iniciativa privada nacional no setor elétrico gaúcho - uma perspectiva histórica das maiores empresas (1887-1928). História em Revista, Pelotas, v.4, 63-94, dezembro/1998. 
BARMAN, R.; BARMAN, J., 1976. The Role of the Law Graduate in the Political Elite of Imperial Brazil. Journal of Interamerican Studies and World Affairs, 18(4), pp.423-450.

BARBOSA, Daniel Henrique Diniz, BARBOSA, Lidiany Silva. Elites técnicas, estado e desenvolvimento regional em Minas Gerais na era Vargas.

CADERNO CRH, v. 23, n. 58, p. 111-128, jan./abr. Salvador, 2010.

BASTOS, Pedro Paulo Zahluth. A Construção do Nacional-

Desenvolvimentismo de Getúlio Vargas e a Dinâmica de Interação entre

Estado e Mercado nos Setores de Base. Economia, ANPEC - Associação

Nacional dos Centros de Pós-graduação em Economia [Brazilian Association of

Graduate Programs in Economics], vol. 7(4), 2006. pages 239-275.

BASTOS, Tavares. (1937) A província: estudo sobre a descentralização do Brasil. São Paulo: Ed. Nacional (Coleção Brasiliana).

BARRINGTON Moore JR. - As Origens Sociais da Ditadura e da Democracia, cap. "As origens revolucionárias da democracia capitalista", Ed. Martins Fontes, 1983.

BELL, Daniel. (1958), The power elite reconsidered. The American Journal of Sociology, 64 (3): 238-250.

BIELSCHOWSKY, R. Pensamento econômico brasileiro: o ciclo ideológico do desenvolvimentismo. Rio de Janeiro: IPEA/INPES, 1988.

BITTENCOURT, Gabriel Augusto de Mello. História Geral e Econômica do Espírito Santo: do engenho colonial ao complexo fabril-portuário. Vitória: Multiplicidade, 2006. 548p.

A formação econômica do

Espírito Santo: o roteiro da industrialização, do engenho às grandes indústrias (1535-1980). Rio de Janeiro: Cátedra; Vitória, ES: Departamento Estadual de Cultura, 1987. 302p.

BOYER, Dominic. Energopolitics: Wind and Power in the Anthropocene. Duke University Press Books. Durham, 2019.

BOSCHI, Renato Raul. Elites industriais e democracia: hegemonia burguesa e mudança política no Brasil. Rio de Janeiro: Graal, 1979.

BLOCH, M. Os reis taumaturgos. São Paulo: Companhia das Letras, 1993.

BOAS, F. A formação da antropologia americana 1883-1911. Rio de Janeiro: Contraponto; UFRJ, 2004.

BRAVIN, Nilvam Jeronimo Ribeiro; BRAVI, Sullien Miranda Ribeiro; GOÉS, Sandra Lucia Videira. A formação industrial no Paraná: do desenvolvimento e formação de aglomerados a distribuição desigual no espaço. 
OBSERVATORIUM: Revista Eletrônica de Geografia, v.7, n.18, p. 48-66, Curitiba, 2015.

BRASIL. Congresso. Comissão Especial Mista destinada a estudar as causas da crise de abastecimento de energia no País, bem como, propor alternativas ao seu equacionamento. Relatório Final $n^{\circ} 2$, Relator Paulo Souto (PFL). Brasília, DF: Câmara dos Deputados, Coordenação de Publicações, 2002. Disponível em: http://legis.senado.leg.br/sdleggetter/documento?dm=3951259\&disposition=inline acessado em 03 de agosto de 2020.

BRAUDEL, F. Escritos sobre a História. São Paulo: Perspectiva, 1969. Le méditerranée. vol. 1 e 2. Paris: Armand Colin, 1990.

BUKETT, Paul; FOSTER, John Bellamy. Marx and the Earth: An AntiCritique. Brill. Boston, 2016. 308 pp.

BRUHNS, Hinnerk. $O$ conceito de patrimonialismo e suas interpretações contemporâneas. Estudos Políticos, n. 4, p. 61-77, 2012.

CANO, W. Crise e industrialização no Brasil entre 1929 e 1954: a reconstrução do Estado Nacional e a política nacional de desenvolvimento. Rev. Econ. Polit. vol.35 no.3 São Paulo Julho/set. 2015.

CASTRO, Iná Elias de. O mito da necessidade - Discurso e prática do regionalismo nordestino. Tese de Doutorado em Ciência Política, Rio de Janeiro, Iuperj, 1989

CARVALHO, José Murilo de. O Federalismo Brasileiro em Perspectiva Histórica. Rio de Janeiro, Mimeo, 1984.

CANO, Wilson. Crise e industrialização no Brasil entre 1929 e 1954: a reconstrução do Estado Nacional e a política nacional de desenvolvimento. Revista de Economia Política, vol. 35, nº 3 (140), pp. 444-460, julhosetembro/2015.

CARDOSO, Fernando Henrique. FALETTO, Enzo. Dependência e desenvolvimento na América Latina. Rio de Janeiro: Zahar, 1970, p. 34.

CARVALHO, José Murilo de. A Construção da Ordem / Teatro de Sombras. Rio de Janeiro: Editora da UFRJ/Relume Dumará, 1996. 2.a ed., Rio de Janeiro: Civilização Brasileira, 2003. 3.a ed., 2004.

CARDOSO, Fernando H. Autoritarismo e democratização. São Paulo, Editora Paz e Terra. 1975

CHALMERS, Johnson. MITI and the Japanese Miracle: The Growth of Industrial Policy, 1925-1975. Stanford, CA: Stanford University Press, 1982. 
CAMARGO, Aspásia Brasileiro Alcântara de. As elites cindidas: o Brasil entre dois marcos da revolução burguesa. Perspectiva Revista de Ciências Sociais. Dossiê: Elites políticas, v. 53 (2019).

CARVALHO, Ricardo Ismael. Nordeste: a força da diferença - Os impasses e desafios na cooperação regional. Editora Massangana, Rio de Janeiro, 2005.

CASS R. Sunstein, Lisa Michelle Ellman \& David Schkade. Ideological Voting on Federal Courts of Appeals: A Preliminary Investigation. Virginia Law Review 301 (2004). Disponível em: https://chicagounbound.uchicago.edu/journal_articles/8398/

CASTRO, Nivalde. ROSENTAL, Rubens. O Estado e o Setor Elétrico

Brasileiro. Jornal do Conselho de Economistas do Rio de Janeiro. Rio de Janeiro, 2016. Acessado em 04 de agosto de 2020. Disponível em:

http://www.gesel.ie.ufrj.br/app/webroot/files/publications/55_castro165b.pdf

CASTRO, N; BRANDÃO, R.; DANTAS, G.; VARDIERO, P.; DORADO, P.: Análise comparativa internacional e desenhos de mercados atacadistas de energia, TDSE $\mathrm{n}^{\circ}$ 75, GESEL, agosto de 2017. Disponível em:

www.gesel.ie.ufrj.br.

CBE. Plano de Eletrificação de Minas Gerais. Secretaria de Viação e Obras Públicas do Estado de Minas Gerais/Companhia Brasileira de Engenharia. Rio de Janeiro, CBE, $1950.5 \mathrm{v}$.

CENTRO DA MEMÓRIA DA ELETRICIDADE NO BRASIL. Lucas Lopes, Memórias do desenvolvimento. Rio de Janeiro, 1991.

Políticas de governo e

desenvolvimento do setor de energia elétrica: do Código de Águas à crise dos anos 80(1934-1984). Eletrobrás, Rio de Janeiro, 1995.

ministro. Eletrobrás, Rio de Janeiro, 1997.

Mauro Thibau: A trajetória de um

. Energia elétrica no Brasil -breve

histórico 1880-2001. Eletrobrás, Rio de Janeiro, 2001.

. A intervenção dos governos estaduais no setor de energia elétrica: os casos do Rio Grande do Sul, de Minas Gerais e do Paraná. Centro da Memória da Eletricidade no Brasil. Eletrobrás, Rio de Janeiro, 2005.

Energia elétrica em questão: debates no Clube de Engenharia. Eletrobrás, Rio de Janeiro, 2001.

Ciclo de Palestras: A Eletrobrás e a

história do setor de energia elétrica no Brasil. Memoria da Eletricidade no Brasil; Coordenação Renato Feliciano Dias. Eletrobrás, Rio de Janeiro, 1995. 
. Caminhos da Modernização:

cronologia da Energia Elétrica no Brasil (1879-2007). Centro de Memória da Eletricidade no Brasil. Eletrobrás, Rio de Janeiro, 2007.

elétrica no Brasil. Eletrobrás, Rio de Janeiro, 1988.

\section{Panorama do setor de energia}

\section{Políticas de governo e}

desenvolvimento do setor de energia elétrica. Do código de Águas à crise dos anos 80 (1934-1984). Rio de Janeiro: 1995, p. 188.

CEPEDA, Vera. Roberto Simonsen e a formação da ideologia industrial no Brasil: limites e impasses. 2004. Tese. (Doutorado em Ciência Política) Faculdade de Filosofia, Letras e Ciências Humanas, Universidade de São Paulo, São Paulo.

Censo Demográfico 1872, 1890, 1900, 1920,1940, 1950, 1960,1970, 1980,1991, 2000 e 2010. IBGE, 2010. Disponível em:

https://censo2010.ibge.gov.br/sinopse/index.php?dados=4\&uf=00 Acesso em: 04/05/2020.

CINGOLANI, L. The State of State Capacity: a review of concepts, evidence, and measures. Working paper, n. 31. Maastricht: Graduate School of Governance, 2013. $58 \mathrm{p}$

CODATO, Evandir. Apontamentos sobre o personalismo político paranaense. Diálogos, DHI/UEM, v. 3, n. 3: 235-261, Maringá, 1999.

CORAZZA, Gentil. Estado e Economia no Brasil - uma revisão da bibliografia recente. Ensaios FEE, Porto Alegre, v. 1, n. 2, p. 189-232, 1981.

CODATO, Adriano. Elites e instituições no Brasil: uma análise contextual do Estado Novo. Tese de Doutorado, Programa de Pós-Graduação em Ciência Política. Universidade Estadual de Campinas (Unicamp), 2008.

COHEN, Sandra. Como a State Grid se tornou a líder do setor elétrico brasileiro. Revista Negócio, Rio de Janeiro, 12 julho de 2019. Disponível em: https://epocanegocios.globo.com/Empresa/noticia/2019/07/como-state-grid-setornou-lider-do-setor-eletrico-brasileiro.html

CPDOC/FGV. Dicionário Histórico-Biográfico Brasileiro On-line: Pedro Viriato Parigot de Sousa. CPDOC/FGV. Rio de Janeiro, 25 out. 2020. Disponível em: http://www.fgv.br/cpdoc/acervo/dicionarios/verbete-biografico/pedro-viriatoparigot-de-sousa

Dicionário Histórico-Biográfico Brasileiro On-line: Manuel Ribas.

Rio de Janeiro, 28 out. 2020. Disponível em:

http://www.fgv.br/cpdoc/acervo/dicionarios/verbete-biografico/ribas-manuelinterv-pr 
Dicionário Histórico-Biográfico Brasileiro On-line: Leonel

Brizola. Rio de Janeiro, 25 out. 2020. Disponível em:

http://www.fgv.br/cpdoc/acervo/dicionarios/verbete-biografico/leonel-de-mourabrizola

. Entre dois governos: 1945-1950 e a constituição de 1946. Rio de Janeiro, 25 nov. 2020. Disponível em:

https://cpdoc.fgv.br/producao/dossies/AEraVargas2/artigos/DoisGovernos/Constit uicao1946.

Dicionário Histórico-Biográfico Brasileiro On-line: Jones dos Santos Neves. Rio de Janeiro, 29 dez. 2020. Disponível em: http:// http://www.fgv.br/cpdoc/acervo/dicionarios/verbete-biografico/jones-dos-santosneves

. Dicionário Histórico-Biográfico Brasileiro On-line: Francisco Lacerda de Aguiar. Rio de Janeiro, 30 nov. 2020. Disponível em: http://www.fgv.br/cpdoc/acervo/dicionarios/verbete-biografico/aguiar-franciscolacerda-de

Dicionário Histórico-Biográfico Brasileiro On-line: Asdrúbal Martins Soares. Rio de Janeiro, 30 nov. 2020. Disponível em: http:// http://www.fgv.br/cpdoc/acervo/dicionarios/verbete-biografico/soares-asdrubalmartins

. Dicionário Histórico-Biográfico Brasileiro On-line: Asdrúbal Martins Soares. Rio de Janeiro, 01 dez. 2020. Disponível em: http://www.fgv.br/cpdoc/acervo/dicionarios/verbete-biografico/eurico-vieira-deresende

. Dicionário Histórico-Biográfico Brasileiro On-line: Floriano Lopes Rubim. Rio de Janeiro, 01 dez. 2020. Disponível em: http://www.fgv.br/cpdoc/acervo/dicionarios/verbete-biografico/floriano-lopesrubim

. Dicionário Histórico-Biográfico Brasileiro On-line: Carlos Fernando Monteiro Lindenberg. Rio de Janeiro, 13 dez. 2020. Disponível em: http://www.fgv.br/cpdoc/acervo/dicionarios/verbete-biografico/carlos-fernandomonteiro-lindenberg

. Dicionário Histórico-Biográfico Brasileiro On-line: Eliezer Batista Da Silva. Rio de Janeiro, 04 dez. 2020. Disponível em: http://www.fgv.br/cpdoc/acervo/dicionarios/verbete-biografico/eliezer-batista-da$\underline{\text { silva }}$

. Dicionário Histórico-Biográfico Brasileiro On-line: Arthur Carlos Gerhardt Santos. Rio de Janeiro, 04 dez. 2020. Disponível em: http://www.fgv.br/cpdoc/acervo/dicionarios/verbete-biografico/artur-carlosgerhardt-santos 
Dicionário Histórico-Biográfico Brasileiro On-line: Élcio Álvares.

Rio de Janeiro, 04 dez. 2020. Disponível em:

http://www.fgv.br/cpdoc/acervo/dicionarios/verbete-biografico/alvares-elcio

Dicionário Histórico-Biográfico Brasileiro On-line: Gerson

Camata. Rio de Janeiro, 04 dez. 2020. Disponível em:

http://www.fgv.br/cpdoc/acervo/dicionarios/verbete-biografico/camata-gerson

Dicionário Histórico-Biográfico Brasileiro On-line: Max Freitas

Mauro. Rio de Janeiro, 04 dez. 2020. Disponível em:

http://www.fgv.br/cpdoc/acervo/dicionarios/verbete-biografico/max-freitas-

mauro.

. Dicionário Histórico-Biográfico Brasileiro On-line: Francisco

Waldir Pires de Sousa. Rio de Janeiro, 04 dez. 2020. Disponível em:

http://www.fgv.br/cpdoc/acervo/dicionarios/verbete-biografico/francisco-waldir-

pires-de-sousa

Dados do ONS, 2018 e do Jornal Nexo, 2019. Disponível em:

https://www.nexojornal.com.br/grafico/2019/01/21/Qual-o-principal-tipo-de-

energia-gerado-em-cada-estado

DAHL, R. A (1997). Poliarquia: participação e oposição. São Paulo:

Universidade de São Paulo.

A Critique of the Ruling Elite Model. American Political Science

Review, 1958, vol. 52, issue 2, 463-469.

DINIZ, E. Crise, reforma do estado e governabilidade. Rio de Janeiro: Editora Fundação Getúlio Vargas, 1997.

Empresário, estado e capitalismo no Brasil: 1930-1945. Coleção

Estudos Brasileiros, v. 27. Rio de Janeiro, Paz e Terra, 1978. 311 p.

Empresariado industrial, representação de interesses e ação

política: trajetória histórica e novas configurações. Política e Sociedade, Florianópolis, vol. 9, n.17, p. 101-139, out., 2010.

DINIZ, Eli; BOSCHI, Renato. Autonomia e Dependência na Representação de Interesses Industriais. Revista Dados, $\mathrm{n}^{\circ}$ 22, 1979.

DRAIBE, Sônia (1985). Rumos e Metamorfoses: Estado e industrialização no

Brasil: 1930-1960. Rio de Janeiro, Paz e Terra.

DULCI, Otavio S. Política e recuperação econômica em Minas Gerais. Belo Horizonte: Humanitas, 1999.

DUARTE, Nestor. A Ordem Privada e a Organização Nacional. $2^{\circ}$ ed., Brasília,1997. 
ECHAVARRIA, José Medina. Consideraciones Sociológicas sobre el Desarrollo Econo- mico de América Latina. Editora Solar/Hachette, Buenos Aires, 1964.

ELAZAR, Daniel J. Federal Systems of the World. New York, Stockton Press, 2004.

EVANS, P. The Capability Enhancing Developmental State: Concepts and National Trajectories. Discussion Paper No. 63 (March). Niterói, Brazil: Centro De Estudos sobre Desigualdade e Desenvolvimento.

EPE. Balanço Energético Interativo. Disponível em: https://www.epe.gov.br/sitespt/publicacoes-dados-abertos/publicacoes/Paginas/Balanco-Energetico-NacionalInterativo.aspx Acessado em: 20/12/2019).

ERENSÜ, Sinan. Powering neoliberalization: Energy and politics in the making of a new Turkey. Energy Research \& Social Science, Volume 41, July 2018, Pages 148-157

ESPÍRITO SANTO (ESTADO). Governador 1952, 1953, 1954. Vitória: Impressa Oficial apud. Silvia, op. cit., p.261, 262, nota 29.

. Plano de valorização econômica do Espírito Santo. Mensagem enviada pelo Sr. Governador a Assembleia Legislativa em 22 de maio de 1951. IJSN, Vitória, ES: 1951

Governador, 1959-1962 (Carlos Lindenberg). Mensagem à Assembleia Legislativa, Imprensa Oficial. p. 3. Vitória,1960. Secretaria de Estado do Planejamento. Estrutura Demografia do Espírito Santo 1977/2000. Vitória, 1977.

governador: discurso. 1967 . Estado do Espírito Santo tem um novo . Of./G nº 0343/94, 16 de março de 1994.

p. 15. Disponível em: . Planejamento de Desenvolvimento ES, 2006. https://planejamento.es.gov.br/Media/sep/Plano\%20ES\%202025/Plano\%20de\%2 0Desenvolvimento\%20ES\%202025.pdf Acessado em: 08 dez. 2020. . Mensagem do Governador Christiano Dias Lopes Filho à Assembleia Legislativa correspondente ao exercício de 1968. In: Estado do Espírito Santo: um estado em marcha para o desenvolvimento. Vitória: 1969.

ESCELSA, Ata da Assembleia Geral Extraordinária. Vitória, 12 de novo de 1973. 
ETZIONI, A. Organizações modernas. 8 ed. São Paulo: Pioneira, 1989.

EVANS, P. O Estado como problema e solução. São Paulo, Lua Nova, v. 2829,1993. Disponível em: http://dx.doi.org/10.1590/S0102-64451993000100006.

2010. Constructing the 21st Century Developmental State:

potentialities and pitfalls. In: EDIGHEJI, O. (ed.). Constructing a Democratic Developmental State in South Africa: potentials and challenges. Cape Town: HSRC.

Institutions and economic development: theory, policy and history. Journal of Institutional Economics, v. 7, n. 4, p. 473-498, 2011.

FAORO, R. Os donos do poder. Formação do patronato político brasileiro. São Paulo: Globo, 1995. v. 1 e 2.

FARIAS, Regina Cláudia Gondim Bezerra. Atuação estatal e a privatização do setor elétrico brasileiro. Dissertação (Mestrado em Ciência Política) - Programa de Mestrado em Ciência Política, Instituto de Ciência Política, Universidade de Brasília, Brasília, 2006.

FERREIRA, Angela Lúcia; SILVA, Alexandro Ferreira Cardoso da; SIMONINI, Yuri. Os donos da luz: sistemas de gestão e redes técnicas no território brasileiro. O caso da AMFORP (1927-1939). Simpósio Internacional Globalizacion Innovacion y construccion de redes técnicas urbanas em America y Europa, 1890 - 1930. Universidade de Barcelona, Facultad de Geografia e História, 23-26 de enero, 2012.

FAORO, R. A questão nacional: a modernização. Estudos Avançados, 6(14), 1992. 7-22. Disponível em https://www.revistas.usp.br/eav/article/view/9563

FELIPE, E. S.; VILLASCHI FILHO, A.; OLIVEIRA, U. J. Aspectos do desenvolvimento econômico do Espírito Santo: a crise econômica da década de 1960, o consenso de necessidades e o governo Cristiano Dias Lopes (19671971). In: I Encontro de Economia do Espírito Santo, Vitória, 2010.

FLEISCHER, D. O recrutamento político em Minas, 1890-1918. Revista brasileira de estudos políticos, p. 9-94, 1971.

FEBVRE, L. Combates pela História. Lisboa: Editorial Presença, 1989.

FURTADO, C. Mito do desenvolvimento econômico. Rio de Janeiro: Paz e Terra, 1974.

FURTADO, Celso. Desenvolvimento e subdesenvolvimento. Rio de Janeiro, Fundo de Cultura, 1961.

FORTUNATO, Danièlle De Oliveira Bresciani. Uma análise do Espírito Santo à luz do processo de implantação dos grandes projetos. Dimensões, vol. 27, 2011, p. 40-62. 
GONTIJO, Paulo Macedo. Discurso do Presidente. In: Revista Mensagem Econômica. Associação Comercial de Minas Gerais, Ano III, Nº 26, fevereiro de 1955, p. 6.

GONÇALVES, Luciana Caldas. Os frágeis galhos dos cafezais e a modernização emergente. Universidade federal do Espírito Santo, Centro de Artes programa de Pós-graduação em Arquitetura e Urbanismo. Vitória, 2010.

GOLDENBERG, José; PRADO, Luiz Tadeu Siqueira. Reforma e crise do setor elétrico no período FHC. Tempo soc. vol.15 no.2 São Paulo Nov. 2003.

GUIMARÃES, Cesar. Empresariado, tipos de capitalismo e ordem política. DADOS - Revista de Ciências Sociais, 1997.

GUPTA, Akhil. An Anthropology of Electricity from the Global South. CULTURAL ANTHROPOLOGY, Vol. 30, Issue 4, 2015. pp. 555-568.

GRYNSZPAN, Mário. (1996), A teoria das elites e sua genealogia consagrada. BIB - Boletim Informativo, 41: 35-83.

HIRSCHMANN, A. (1964). The Paternity of an Index. American Economic Review, 54, 761.

HOLLANDA, Cristina Buarque de. Teoria das elites. Rio de Janeiro: Zahar, 2011.

HOBSBAWM, E. Marx \& L’Histoire: textes inédits. Paris: Demopolis, 2008.

Sobre História. São Paulo: Companhia das Letras, 2010.

HUGHES, L. (2014). Explaining changes in oil market governance.

In Globalizing Oil: Firms and Oil Market Governance in France, Japan, and the United States (Business and Public Policy, pp. 39-67). Cambridge: Cambridge University Press. doi:10.1017/CBO9781107323643.004

HUGHES, Llewelyn; LIPSCY, Phillip. 2013. The Political Economy of Energy. Annual Review of Political Science Vol. 16: 449-469.

IANNI, Octávio; Estado e Planejamento Econômico no Brasil (1930-. 1970), Editora Civilização Brasileira. Rio de Janeiro, 1971.

IBGE. Recenseamento geral: censo econômico, 1940.

IPEA. Capacidades estatais e democracia: arranjos institucionais de políticas públicas. Editores: Alexandre de Ávila Gomide, Roberto Rocha C. Pires. Brasília, 2014.

IKENBERRY, John. Reasons of State: Oil Politics and the Capacities of American Government. By G. John Ikenberry. Ithaca, NY: Cornell University Press, 1988. 
INSTITUTO JONES DOS SANTOS NEVES (IJSN). Espírito Santo: instituições, desenvolvimento e inclusão social. Vitória, ES, 2010

JAGUARIBE, Hélio. Desenvolvimento econômico e desenvolvimento político. Fundo de Cultura. Rio de Janeiro, 1962.

KANT, I. Fundamentação da metafísica dos costumes. Lisboa : Edições 70, 1986.

Idée d'une Histoire universelle au point de vue cosmopolitique.

Traduçãode Jean-Michel Muglioni. Paris: Bordas, 1988.

KATZENSTEIN, Peter J. Between Power and Plenty: Foreign Economic Policies in Advanced Industrial States. University of Wisconsin Press. Madison, 1978.

. "International Relations and Domestic Structures:

Foreign Economic Policies of Advanced Industrial States." International Organization, 1976. 30:1-45.

KELLER, Suzanne. (1967), O destino das elites. Rio de Janeiro, Forense.

KRASNER, Stephen D. Defending the National Interest: Raw Materials Investments and U.S. Foreign Policy. Princeton University Press. Princeton, N.J.: 1978.

LASSWELL, Harold D. \& LERNER, Daniel. (1967). As elites revolucionárias. Rio de Janeiro, Zahar.

LANDI, Mônica. Energia elétrica e políticas públicas: a experiência do setor elétrico brasileiro no período de 1934 a 2005. Tese de Doutorado, USP. São Paulo, 2006.

LEVINE, R. A velha usina: Pernambuco na federação brasileira, 1889-1937. Rio de Janeiro: Paz e Terra, 1980.

LIMA, José Luiz. Políticas de governo e desenvolvimento do setor de energia elétrica: do Código de águas à crise dos anos 80 (1934-1984). Rio de Janeiro: Memória da Eletricidade, 1995.

LOBO, Maria Thereza (1986). Organização do Poder Público e Regiões Metropolitanas. In BRASILEIRO, A. M. (Org.). Alternativas políticoinstitucionais para a região metropolitana de Salvador - dimensão nacional. Convênio IBAM/CONDER. Rio de Janeiro: IBAM/CPU, pg. 25-49.

LOVE, J. A locomotiva: São Paulo na federação brasileira, 1889-1937. Rio de Janeiro: Paz e Terra, 1982.

LORENZO, Helena Carvalho de. O setor elétrico brasileiro: passado e futuro. Perspectiva: Revista de Ciências Sociais. 24-25, 147-170. 2001, 2002. 
MARX, K. Crítica da filosofia do direito de Hegel. São Paulo: Boitempo, 2010. O 18 Brumário de Luís Bonaparte. São Paulo: Boitempo, 2011.

MAZA, Fabio. O idealismo prático de Roberto Simonsen. São Paulo: Fiesp, 2004

MATTOS, Ilmar Rollof. O Tempo Saquarema. São Paulo: HUCITEC, 1986.

MAZZUCATO, Mariana. O Estado empreendedor: desmascarando o mito do setor público x setor privado. São Paulo: Portfolio-Penguin, 2014.

MCDONALD, David. 2010. Eletric capitalism: recoloning Africa on the grid. London/Cape Town: Leart hscan

MEDEIROS, Antônio Carlos. Espírito Santo: a industrialização como fator de desautonomia relativa. Dissertação de mestrado (Mestrado em Administração Pública). Escola Brasileiro de Administração Pública da Fundação Getúlio Vargas, Rio de Janeiro, 1997; Arquivo Público do Estado do Espírito Santo. IBC/GERCA, 1979.

MELBY, Eric D. K. Oil and the International System: The Case of France, 1918- 1969. New York: Arno Press, 1981.

MILLS, Charles Wright. (1958), The structure of power in American society. The British Journal of Sociology, 9 (1): 29-41.

MIGLIORINI, Sonia Mar dos Santos. Indústria Paranaense: Formação, transformação econômica a partir da década de 1960 e distribuição espacial da indústria no início do século XXI. Revista Eletrônica Geografar, v. 1, n. 1, p. 62-80, Curitiba: 2006.

MITCHELL, Timothy. Carbon democracy: political power in the age of oil. Economy and Society. Verso. London, 2011.

MICHELS, R (1982). Sociologia dos partidos políticos. Brasília: Universidade de Brasília.

MIGDAL, Joel S. State in Society: Studying how states and societies transform and constitute one another. Cambridge: Cambridge University Press, 2001.

MORSE, Richard. O Espelho de Próspero: cultura e ideias nas Américas [1982]. Trad. Paulo Neves. São Paulo: Companhia das Letras, 1988.

MOSCA, G (1992). La classe política. México: Fondo de Cultura Econômica.

MONTEIRO NETO, Aristides. Governos estaduais no federalismo brasileiro: capacidades e limitações no cenário atual. Texto para discussão / Instituto de Pesquisa Econômica Aplicada. - Brasília - Rio de Janeiro: Ipea, 2013. 
NATHANIEL H. LEFF. Economic Policymaking and Development in Brazil, 1947-1964. Pp. xiv, 201. New York: John Wiley \& Sons, 1968.

OLIVEIRA, Andréa Cristina de Jesus. Breve histórico sobre o desenvolvimento do lobbying no Brasil. Revista de informação legislativa, v. 42, n. 168, p. 29-43, out./dez. 2005

OLIVEIRA, Ueber José de. Elites Capixabas no golpe de 1964: bipartidarismo e a convergência de agendas desenvolvimentistas (1964-1982). Editora Milfontes. Serra, 2018. p. 280

OLIVIERI, C.Os. Controles políticos sobre a burocracia. Revista de Administração Pública, v. 45, n. 5, p. 1395-1424, 2011.

(2006). Regulatory agencies and federalism: the decentralized management of the energy sector regulation. Brazilian Journal of Public Administration, 40(4), 567 a 588.

PARANA. Lei estadual n ${ }^{\circ}$ 1384, de 10 de outubro de 1953.

PARETO, V (1984). Pareto. RODRIGUES, J. A. (Org.). São Paulo: Ática.

PARSONS, T. Distribution of power in american Society. World Politics 10: 123-43

PANG, Eul-Soo e SECKINGER, Ron L. The mandarins of Imperial Brazil. Comparative studies in Society and History, v.14, n.217-245, March 1972.

PESAVENTO, Sandra Jatahy. História do Rio Grande do Sul. Editora Mercado Aberto. Porto Alegre, 1982.

PERISSINOTO, Renato. O conceito de Estado desenvolvimentista e sua utilidade para os casos brasileiro e argentino. Rev. Sociol. Polít. Vol.22 no.52 Curitiba Oct. /Dec. 2014.

O conceito de estado desenvolvimentista e sua utilidade para os casos brasileiro e argentino. Rev. Sociol. Polit. [online]. 2014 Por que é importante estudar as elites políticas? Perspectivas, São Paulo, v. 53, p. 137-158, jan./jun, 2019.

PETER, B., RUESCHEMEYER, Dietrich \& SKOCPOL, Theda. Bringing the State Back In. Cambridge: Cambridge University Press, 1985.

PECI, Alketa; Cavalcanti, Bianor. A Outra Face da Regulação: o Cidadão no Novo Modelo Regulatório Brasileiro. Publicado em Revista de Direito Público da Economia -RDPE, Belo Horizonte, ano 1, n 3, pág. 9-31, jul/set. 2003. 
PEREIRA, A. R. Governos de coalizão no Espírito Santo (1986/98). In:

ENCONTRO NACIONAL DA ABCP, 3., 2002, Niterói. Anais... Niterói: ABCP, 2002.

POULANTZAS, N. 1978. State, Power, Socialism. London: New Left.

POULANTZAS, N. (1977) Poder político e classes sociais. São Paulo : Martins Fontes.

POSNER, Richard. Theories of Economic Regulation. Bell Journal of Economics, 1974, vol. 5, issue 2, 335-358

POULANTZAS, N. Poder político e classes sociais. 2. ed. São Paulo: Martins Fontes, 1986.

PREFEITURA MUNICIPAL DE VITÓRIA. GAB/82/93-Circ., 28 de fevereiro de 1994.

PUTNAM, R. (1976). The comparative study of political elites. New Jersey, Prentice-Hall.

QUEIROZ, Maria Isaura Pereira. (2006) O Coronelismo Numa Interpretação Sociológica. In: FAUSTO, Boris (Org.) História Geral da Civilização Brasileira. $2^{\circ}$ ed., São Paulo: DIFEL, p.155-188.

RAPOSO, Eduardo. Banco Central do Brasil: o leviatã ibérico: uma interpretação do Brasil contemporâneo. São Paulo: Hucitec; Rio de Janeiro: PUC-Rio, 2011.

1930: Seis versões e uma revolução - História oral da política paraibana (1889-1940) - Recife: / Eduardo Raposo. Fundação Joaquim Nabuco, Editora Massangana, 2006.

REIS, E. P. 1979. The Agrarian Roots of the Authoritarian Modernization in Brazil: 1880-1930. PhD. Dissertation. Massachusets, Massachusets Institute of Technology

RIO GRANDE DO SUL (ESTADO). Plano de Eletrificação do estado: plano regional preliminar de eletrificação do Rio Grande do Sul, 1945.

Lei estadual $n^{0} 1744$, artigo 2, letra $K$

RIBEIRO, Luiz Cláudio M. Excelsos destinos: história da energia elétrica no Espírito Santo 1896-1968. EDUFES. Vitória, 2013.

RIFKIN, Jeremy. (2011) The third revolution. How lateral power is transforming energy, the economy and the world. New York: Palgrave Macmillan. 
RIBEIRO, Diones Augusto. Planejamento e industrialização no Espírito Santo: o conselho de desenvolvimento econômico do Espírito Santo (CODEC). Anais do VI Congresso Internacional UFES/Paris-Est, Vitória, 2012.

Rizzi, Leonardo Effgen. Privatização e trabalho no Brasil: o caso Escelsa (Espírito Santo Centrais Elétricas S.A). Dissertação (mestrado), Universidade Federal do Espírito Santo, Centro de Ciências Humanas e Naturais, 2008.

RODRIGUES, Marcos Aurélio, et. al. A distribuição da indústria de transformação no Paraná no período de 2002 a 2007: uma análise espacial. In: Encontro Nacional da Associação Brasileira de Estudos Regionais e Urbanos, 7, São Paulo: 2009. p. 01-17.

ROSA, L., TOLMASQUIM, M., PIRES, J. C. L. A reforma do setor elétrico no Brasil e no mundo: uma visão crítica. Rio de Janeiro: Ed. Relume Dumará,1998.

ROCHA, Haroldo Corrêa; MORANDI, Ângela Maria. Cafeicultura e grande indústria. A transição no Espírito Santo 1955-1985. Vitória, ES: Espírito Santo em Ação, 2012.

ROSA, Luiz Pinguelli; Hoffman, Carlos Augusto Amaral. Cenários sobre o Impacto da Privatização do Setor Elétrico nas Tarifas: O Caso da Escelsa. Revista Brasileira de Energia, Vol. 4, No 2. Sociedade Brasileira de Planejamento Energético, 1995.

ROCHA, H. C.; MORANDI, A. M. Cafeicultura e grande indústria: a transição no Espírito Santo 1955-1985. Espírito Santo em Ação. 2.ed. Vitória, 2012.

RUESCHEMEYRER, Dietrich and EVANS, Peter B. (1985) "The state and economic transformation: toward an analysis of the conditions underlying effective". In Evans,

SAES, Alexandre Macchione. Conflitos do capital: Light versus CBEE na formação do capitalismo brasileiro (1898-1927). 2008. 422 p. Tese (doutorado) - Universidade Estadual de Campinas, Instituto de Economia, Campinas, SP. Disponível em: 〈http://www.repositorio.unicamp.br/handle/REPOSIP/285787>. Acesso em: 11 ago. 2018.

Luz, leis e livre-concorrência: conflitos em torno das concessões de energia elétrica na cidade de São Paulo no início do século XX. HISTÓRIA, São Paulo, 28 (2): 2009.

SANTOS, Arthur Carlos Gerhardt. O Pequeno Grande Estado. Revista Espírito Santo Agora. Vitória, Ano III, n. 11, p. 10, fev. 1974.

SAMARCO. Relatório Anual de Sustentabilidade, 2006. Disponível em: https://www.samarco.com/wp-content/uploads/2016/08/2006-Relatorio-Anual-deSustentabilidade.pdf Acessado em: 08 dez. 2020 
SCHWARCZ, L. M., \& STARLING, H. M. M. Brasil: uma biografia.

Companhia das Letras. São Paulo, 2015.

SCHWARTZMAN, Simon. Bases do autoritarismo brasileiro. 5a ed. Editora Unicamp. Rio de Janeiro, 2015.

SCHMITTER, Philippe C. - Interest conflict and political change in Brazil. Stanford, California: Stanford University Press, 1971.

SCHNEIDER, S. Agricultura familiar e industrialização: pluriatividade e descentralização industrial no Rio Grande do Sul. Porto Alegre: editora Universidade/UFRGS, 1999.

SILVA, Marta Zorzal. Espírito Santo: estado, interesses e poder. Volume 11. Dissertação. Escola Brasileira de Administração pública, FGV, 1986.

SILVA, Marcelo Squinca da. Energia Elétrica e Industrialização: expansão do parque energético de Minas Gerais nos anos 1950. II Simpósio Internacional Eletrificação e Modernização Social. São Paulo, 2013.

SILVA, Marco Antônio Medeiros da. A última revolução: o governo Leonel Brizola no Rio Grande do Sul, 1959-1963. Tese (Doutorado em História) Pontifícia Universidade Católica do Rio Grande do Sul. Porto Alegre, 2015.

SILVA, Marta Zorzal de. Espírito Santo: Estado, interesses e poder. Dissertação (Mestrado em Administração Pública) -Escola Brasileira de Administração Pública, Fundação Getúlio Vargas, Rio de Janeiro, 1986.

A Vale do Rio Doce na estratégia do desenvolvimentismo brasileiro. EDUFES. Vitoria, 2004.

SKOCPOL, T.; FINEGOLD, K. State capacity and economic intervention in the early New Deal. Political science quarterly, v. 97, n. 2, p. 255-278, 1982.

SOUZA, Maria do Carmo Campello. Estado e partidos políticos no Brasil (1930 a 1964). São Paulo, Alfa-Omega, 1976.

SOLA, Lourdes. Reformas do Estado para qual democracia? O lugar da política. In: PEREIRA, Bresser, WILHEIM, Jorge, SOLA, Lourdes (Orgs). Sociedade e Estado em transformação. São Paulo: Unesp/Brasília: ENAP, 1999, 23-66.

SOUZA, Celina. Constitucional engineering in Brazil: the politics of federalismo and descentralization. New York, St. Martin`s Press, 1997, pp. 171180.

SUZIGAN, W. Indústria brasileira. São Paulo, Brasiliense, 1986. 
SUZIGAN, Wilson; FURTADO, João. Política Industrial e Desenvolvimento. Revista de Economia Política, vol. 26, nº 2 (102), pp. 163-185 abril-junho/2006.

SENADO FEDERAL. Constituição da República Federativa do Brasil: quadro comparativo. Brasília, Senado Federal, 1996, pp. 99 e 441

TRINTIN, Jaime Graciano e IZEPÃO, Rosalina Lima. Estado, planejamento e desenvolvimento industrial no paraná. ANPUH - XXII Simpósio Nacional de História - João Pessoa, 2003.

TILLY, Charles. Coerção, capital e estados europeus: 1990-1992. São Paulo: EDUSP, [1996].

(org.). The formation of national states in Western Europe.

Princeton: Princeton University Press, 1975.

VIANNA, Sérgio Besserman. A política econômica no Segundo Governo Vargas: 1951-1954. Rio de Janeiro: Banco Nacional de Desenvolvimento Econômico e Social, 1987. 181 p.

VIANNA, J. Oliveira. (1987) Populações Meridionais do Brasil. Niterói: Eduff.

VIEIRA, José Paulo. Energia elétrica como antimercadoria e sua metamorfose no Brasil: a reestruturação do setor e as revisões tarifárias. São Paulo, 2005.

VILLASCHI, Arlindo. Revisitando o tema Fundap. Blog de Economia Capixaba. Disponível em: http://www.economiacapixaba.worldpress.com/2012/02/06/86/. Acessado em 08/10/2020.

WALKER, Jack L. (1966). A critique of the elitist theory of democracy. The American Political Science Review, 60 (2): 285-295.

WANICK, Flavio Calmon. Presidente Aristeu Borges de Aguiar, de positiva unanimidade a expectativas frustradas. A política e a economia capixabas durante os anos 1928 a 2007. Dissertação (mestrado) - Universidade Federal do Espírito Santo, Centro de Ciências Humanas e Naturais. Vitória, 2007.

WINTHER, Tanja. LESDAIN, Sophie Bouly de. Electricity, Uncertainty and the Good Life A Comparison of French and Norwegian Household Responses to Policy Appeals for Sustainable Energy. Energy and Environment Research; Vol. 3, No. 1; 2013.

WIRTH, J. O fiel da balança: Minas Gerais na federação brasileira. Rio de Janeiro: Paz e Terra, 1982.

WINTHER, T. (2008). The Impact of Electricity. Development, Desires and Dilemmas. Oxford: Berghahn Books. 
WEBER, Max. Economy and Society. Edited and translated in part by Guenther Roth and Claus Wittich. Berkeley: University of California Press, 1978. . Ensaios de Sociologia. Ed. Guanabara: Rio de Janeiro, 1981.

WEAVER, R. Kent; Rockman, Bert A. Do Institutions Matter? Government Capabilities in the United States and Abroad. Washington D.C.: The Brookings Institution, 1993.

Discurso do Presidente do Espírito Santo. Jornal A Gazeta. 05/05/1930, n. 136, p. 01. Acessado em 10/07/2019.

Assembleia aprova a venda das ações da Escelsa. Jornal A Gazeta. 10 de abril de 1994. Vitória, p. 4, 7.

Capa. Jornal A Gazeta, 01 de fevereiro de 1959, p. 01.

Estado ganha mais 7 usinas. A Tribuna, Vitória, ES, 01/10/2008, p.27.

Estado ganha mais 7 usinas. A Tribuna, Vitória, ES, 01/10/2008, p.27.

Hartung deve seguir conselho de Lula e confirmar filiação no PMDB. Futuro partidário do governador foi discutido em encontro com o presidente. A Gazeta, Vitória, ES, 09/02/2005, p.14, c.1-6.

Há 3 anos, rompimento de barragem de Mariana causou maior desastre ambiental do país e matou 19 pessoas. Portal G1, em São Paulo. 25 de janeiro de 2019. Disponível em: https://g1.globo.com/mg/minas-gerais/noticia/2019/01/25/ha-3anos-rompimento-de-barragem-de-mariana-causou-maior-desastre-ambiental-dopais-e-matou-19-pessoas.ghtml Acessado em: 08 dez. 2020

Hartung pede a Lula novo linhão e termelétrica contra o apagão. A Gazeta, Vitória, ES, 02/10/2007, p.16.

Investimentos garantem térmicas em 2003. Jornal A Gazeta, Vitória, ES, 20 de setembro de 2001, p.07.

Roteiro (de Governo) do Candidato Carlos Lindenberg. Jornal A Gazeta, 19 de março de $1958,1^{\mathrm{a}} \mathrm{p}$. 